\title{
The state and diagnostic value of plasma tissue factor in early-hospitalised patients with chest pain
}

Citation for published version (APA):

van der Putten, R. F. M. (2005). The state and diagnostic value of plasma tissue factor in earlyhospitalised patients with chest pain. [Doctoral Thesis, Maastricht University]. Universiteit Maastricht. https://doi.org/10.26481/dis.20051102rp

Document status and date:

Published: 01/01/2005

DOI:

10.26481/dis.20051102rp

Document Version:

Publisher's PDF, also known as Version of record

\section{Please check the document version of this publication:}

- A submitted manuscript is the version of the article upon submission and before peer-review. There can be important differences between the submitted version and the official published version of record.

People interested in the research are advised to contact the author for the final version of the publication, or visit the DOI to the publisher's website.

- The final author version and the galley proof are versions of the publication after peer review.

- The final published version features the final layout of the paper including the volume, issue and page numbers.

Link to publication

\footnotetext{
General rights rights.

- You may freely distribute the URL identifying the publication in the public portal. please follow below link for the End User Agreement:

www.umlib.nl/taverne-license

Take down policy

If you believe that this document breaches copyright please contact us at:

repository@maastrichtuniversity.nl

providing details and we will investigate your claim.
}

Copyright and moral rights for the publications made accessible in the public portal are retained by the authors and/or other copyright owners and it is a condition of accessing publications that users recognise and abide by the legal requirements associated with these

- Users may download and print one copy of any publication from the public portal for the purpose of private study or research.

- You may not further distribute the material or use it for any profit-making activity or commercial gain

If the publication is distributed under the terms of Article $25 \mathrm{fa}$ of the Dutch Copyright Act, indicated by the "Taverne" license above, 
THE STATE AND DIAGNOSTIC VALUE OF PLASMA TISSUE FACTOR

IN EARLY-HOSPITALIZED PATIENTS WITH CHEST PAIN 
The studies presented in this thesis were performed at the departments of Genetics \& Cell Biology and Physiology, Cardiovascular Research Institute Maastricht (CARIM), Maastricht University, the Netherlands.

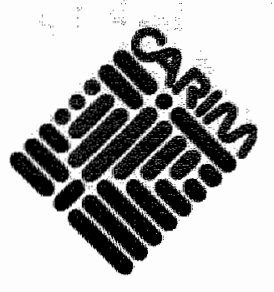

(c) Roy van der Putten, Maastricht 2005

ISBN-10: 9085900042

ISBN-13: 9789085900047

Printed by: Ponsen \& Looijen 


\title{
THE STATE AND DIAGNOSTIC VALUE OF PLASMA TISSUE FACTOR IN EARLY-HOSPITALIZED PATIENTS WITH CHEST PAIN
}

\section{Proefschrift}

ter verkrijging van de graad van doctor aan de Universiteit Maastricht, op gezag van de Rector Magnificus, Prof. mr. G.P.M.F. Mols, volgens het besluit van het College van Decanen, in het openbaar te verdedigen op woensdag 2 november 2005 om 12:00 uur.

\author{
door
}

Roy Franciscus Maria van der Putten geboren op 15 augustus 1974 te Nijmegen 


\section{Promotores:}

Prof. dr. W.T. Hermens

Prof. dr. J.F.C. Gtatz

\section{Beoordelingscommissie:}

Prof. dr. H. ten Cate (voorzitter)

Prof. dr. M.P. van Dieijen-Vîsser

Dr. T. Lindhout

Prof. dr. A. Sturk (AMC, Amsterdam)

Dr. R.J. de Winter (AMC, Amsterdam)

The studies described in this thesis were supported by grants of the Netherlands Heart Foundation (NHF-98.063 and NHF-2002B189).

Financial support by the Netherlands Heart Foundation and the Dr. Ir. van de Laar Stichting for the publication of this thesis is gratefully acknowledged. 
"Be careful about reading health books.

You may die of a misprint."

- Mark Twain 



\section{CONTENTS}

Chapter 1: General introduction

Chapter 2: Plasma markers of activated blood coagulation

in acute coronary syndromes

Chapter 3: $\quad$ High-affinity antibodies in a new ELISA

for plasma tissue factor. Reduction of apparent intra-individual variation

Chapter 4: Quantitative comparison of the concentrations of tissue factor antigen and tissue factor activity in plasma and serum of healthy donors

Chapter 5: $\quad$ Fatty acid-binding protein as an early plasma marker of myocardial ischemia and risk stratification

Chapter 6: State and diagnostic value of plasma tissue factor in early-hospitalized patients with chest pain

Chapter 7: General discussion

Summary

Samenvatting

Dankwoord 
(1) 
CHAPTER 1

GENERAL INTRODUCTION 
Chest pain is a common presentation complaint in the emergency department ${ }^{1}$ and the task of evaluating and diagnosing chest pain is a major challenge in health care. Acute coronary syndromes (ACS) refer to any constellation of clinical symptoms that are compatible with acute myocardial ischemia. ACS therefore encompasses acute myocardial infarction (AMI), unstable angina pectoris (UAP) and sudden cardiac death. In the year 2002 in the Netherlands, $31 \%$ of all 272,275 patients admitted to the hospital with cardiovascular diseases were ultimately diagnosed with ACS ${ }^{2}$.

\section{$>$ | DIAGNOSIS OF ACUTE CORONARY SYNDROMES}

For much of the past three decades, acute myocardial ischemia has been regarded as a binary phenomenon, AMl or non-AMl ${ }^{3,4}$. According to World Health Organization (WHO) recommendations ${ }^{5}$, diagnosis of $A M I$ requires fulfillment of at least two of the following three criteria: i) clinical symptoms suggestive of myocardial ischemia; ii) presence of specific and significant electrocardiographic changes on the ECG; and iii) increased plasma or serum levels of markers of myocardial necrosis.

For the first criterion, careful assessment of clinical symptoms is of paramount importance. A history of acute, severe, and prolonged chest pain is suggestive of AMI. Chest pain is, however, an unreliable indicator: up to 33\% of patients with AMI may have no chest pain and are 'clinically silent' on presentation to the hospital ${ }^{6}$.

The second criterion, changes on the ECG, is the cornerstone for the early diagnosis of acute ischemia, and should be performed quickly after presentation of the suspected AMI patient because those having either STsegment elevation $>1 \mathrm{mV}$ in contiguous leads or symptoms of new left bundle branch block are candidates for immediate reperfusion therapy ${ }^{7}$. However, the ECG has been reported to be non-diagnostic in $20-50 \%$ of cases ${ }^{8.10}$, thereby showing a globally low sensitivity.

The final WHO-criterion involves monitoring in plasma or serum of the temporal change in markers of myocardial necrosis. A concentration of cardiac troponin exceeding the decision limit on at least one occasion during the first 24 hours after the onset of the clinical event has been suggested to be the best biochemical indicator for detecting myocardial necrosis, although the use of creatine kinase-MB isoenzyme (CK-MB), measured by mass assays, is still considered as an acceptable alternative if cardiac troponin assays are not availlable ${ }^{11}$. 


\section{MARKERS OF MYOCARDIAL NECROSIS}

In symptomatic patients presenting with diagnostic ECG changes, cardiac markers have a limited role in the context of acute AMI diagnosis, except for confirmation and infarct size estimation. On the other hand, these markers are essential in the diagnosis of patients who present with non-specific or vague symptoms and/or a non-diagnostic ECG, because they represent one of the two criteria upon which the AMI diagnosis rests.

\section{Acute myocardial infarction}

To identify patients with AMI, serial assessment of CK-MB and cardiac troponin $\mathrm{T}(\mathrm{TnT})$ or cardiac troponin I (Tnl) at 4 - to 6 - $\mathrm{h}$ intervals is obligatory because of the time lag of CK-MB and troponin increases after the onset of chest pain ${ }^{12}$. As a consequence, the measurement of $C K-M B$ and troponin does not allow a rapid AMI diagnosis in patients admitted in the early hours after onset of symptoms. Determination of myoglobin (Myo) or fatty acid-binding protein (FABP) allows a higher sensitivity for the early detection of myocardial damage ${ }^{13,14}$, with FABP slightly outperforming Myo due to its lower reference plasma level ${ }^{14-18}$. However, even Myo or FABP will often not allow AMI diagnosis in patients that are hospitalized within 3.4 hours after onset of symptoms.

Hence, novel early markers of AMI are desirable for more rapid triaging of patients admitted to the hospital with chest pain suggestive of AMI to: i) facilitate early intervention with reperfusion therapy in patients with AMI, (ii) reduce costs as a result of early discharge of patients without AMI.

\section{Unstable angina pectoris}

The syndrome of UAP covers a very heterogenous group of patients. Part of these patients have a high risk of developing AMI within hours to days whereas the others only have a low risk, so that early discharge would be a safe option. Considering the low plasma concentrations of troponin in healthy persons, a rise in troponin has been found in approximately one third of patients presenting with UAP without elevated CK-MB ${ }^{19-23}$. This subgroup of patients appears to have a prognosis as serious as patients with definite AMI 20,24 . This is a unique potential of the troponins, which is described by the term "minor myocardial injury". However, elevated troponin levels are not detected within 6-8 hours after the onset of symptoms.

Thus, there is an urgent need for more rapid tests to: (i) identify patients with UAP who are at high risk of developing AMI and require admission to the coronary care unit (CCU), and (ii) exclude low-risk patients with UAP who can be safely sent home and followed as outpatients (cost reduction). 


\section{$>$ MARKERS OF COAGULATION ACTIVATION}

Intra-coronary thrombosis plays a key role in the pathogenesis of ACS, and the formation of a (partially) occlusive thrombus usually precedes the development of myocardial necrosis ${ }^{25,26}$. A considerable amount of studies, which will be discussed in Chapter 2, have reported on coagulation activation in the acute phase of ACS. Most of these studies focused their attention on markers of thrombin generation (prothrombin fragment $1+2(F 1+2)$, thrombinantithrombin complexes (TAT)) and thrombin activity (fibrinopeptide A (FPA)), and revealed that their plasma levels were increased in the majority of patients with ACS.

\section{Tissue factor - a promising early marker of coagulation activation?}

Arterial thrombosis had always been considered to arise strictly from the interaction of tissue factor (TF) in the vascular wall with platelets and coagulation factors in the circulating blood. According to this paradigm, coagulation is initiated after a vessel is damaged and blood is exposed to vascular wall-TF. However, with the development of assays that are able to detect protein concentrations as low as $100-200 \mathrm{pg} / \mathrm{mL}$, tissue factor antigen has been found to be present in plasma from healthy subjects ${ }^{27-30}$. Moreover, a number of studies reported increased plasma TF antigen levels in the acute phase in patients with unstable angina ${ }^{31-36}$ and myocardial infarction ${ }^{37-39}$. Since there is no international standard, these assays commonly use a recombinant non-lipidated full-length TF as standard. However, the validity of using such a standard is not yet fully established, since different TF entities may circulate in plasma.

The interpretation of plasma TF antigen assays is complicated by the fact that it is not clear whether plasma TF is in a functional or in a non-functional ('encrypted') form. Unfortunately, due to the limited availability of assays that are capable of measuring plasma TF activity, the role of plasma TF remains poorly understood. Giesen et al. ${ }^{40}$ were able to extract TF from plasma of healthy subjects, and showed that it was potentially active. A chromogenic assay for measurement of TF activity in plasma has been described ${ }^{41,42}$, but this method requires prior preparation of the euglobulin fraction and is difficult to reproduce ${ }^{28}$. Using this assay, He et al. ${ }^{38}$ reported increased plasma TF activity in plasma from AMI patients. Others ${ }^{43,44}$ have developed an assay to measure TF activity on microparticles isolated from plasma, but this assay has not yet been used to assess TF activity in ACS patients.

The finding that only a few groups have reported data on plasma TF activity is probably due to the presence of many procoagulant and 
anticoagulant pathways involved in blood coagulation (see Chapter 2) that complicate the direct measurement of TF activity in plasma.

\section{COMBINATIONS OF MARKERS OF MYOCARDIAL NECROSIS AND COAGULATION ACTIVATION}

In general, markers of coagulation activation are rapidly cleared from the circulation, and thus become less useful with longer periods after the acute event. In contrast, as explained previously, markers of myocardial necrosis are not detectable until a few hours after the acute event. Therefore, in order to establish an accurate diagnosis that is independent on the delay of the patient to the hospital, it could be useful to combine plasma markers of coagulation activation and myocardial necrosis. Such a combined test can be expected to allow early initiation of appropriate reperfusion therapy and a reduction of hospitalizations.

As will be shown in Chapter 2, only a handful of studies have reported on sensitivities and specificities of hemostatic markers and on their use in combinations with markers of myocardial necrosis for the detection of ACS in a clinical setting. As will be discussed, it is not clear from these studies whether combining markers of coagulation activation and myocardial necrosis is valuable in the early diagnosis of ACS. None of these studies have addressed the value of measurement of TF antigen and TF activity in the acute phase of ACS. Therefore, the value of these markers in the early diagnosis of ACS still needs to be elucidated in well-organized clinical trials considering large groups of patients.

\section{AIMS OF THE STUDY}

The principal aim of the thesis was to evaluate the combination of markers of coagulation activation and myocardial necrosis for the early diagnosis of ACS.

Specific aims of the thesis were:

1. Development of sensitive assays for the measurement of TF antigen and of TF activity in plasma.

2. Evaluation of the use of FABP in combination with markers of activated blood coagulation - particularly TF antigen and TF activity in the diagnosis of patients presenting at the emergency department with chest pain suggestive of ACS.

3. Better understanding of the state of plasma TF. 


\section{$>\mid$ OUTLINE OF THIS THESIS}

In Chapter 2, studies that have reported on plasma levels of markers of coagulation activation in the acute phase of ACS are reviewed. The development of a sensitive assay for the measurement of TF antigen in plasma is described in Chapter 3. This assay was evaluated by measurement of TF antigen levels in plasma from type 2 diabetes patients, which were compared with the levels that were obtained by using a commercially available assay. A highly sensitive assay to measure TF activity levels in plasma was developed, which is described in Chapter 4. Reference intervals for both plasma TF antigen and TF activity levels in healthy donors were established, and for the first time, directly compared. Subsequently, these assays were used to determine plasma TF antigen and TF activity levels in the acute phase of ACS patients. In Chapter 5, the characteristics of FABP, currently the best early marker for the detection of myocardial necrosis are described. In Chapter 6, the performance of TF antigen and TF activity in a panel of markers of coagulation activation, and their combination with FABP in the early diagnosis of ACS is evaluated. Finally, a general discussion of the results obtained in this thesis and the clinical implications of the measurement of markers of coagulation activation in the diagnosis of ACS are presented in Chapter 7, and a brief summary concludes this thesis. 
1. Kamineni R, Alpert JS. Acute coronary syndromes: initial evaluation and risk stratification. Prog Cardiovasc Dis. 2004;46:379-92.

2. Nederlandse Hartstichting. Hart- en waatziekten in Nederland 2004, cijfers over leefstijl-en risicofactoren, ziekte en sterfte.

3. Christenson RH, Azzazy HM. Biochemical markers of the acute cononary syndromes. Clin Chem. 1998;44:1855-64.

4. Panteghini M. Acute coronary syndrome: biochemical strategies in the troponin era. Chest. 2002;122:1428-35.

5. Nomenclature and criteria for diagnosis of ischemic heart disease. Report of the Joint International Society and Federation of Cardiology/World Health Organization task force on standardization of clinical nomenclature. Circulation. 1979;59:607-9.

6. Canto JG, Shlipak MG, Rogers WJ, Malmgren JA, Frederick PD, Lambrew CT, Ornato JP, Barron HV, Kiefe Cl. Prevalence, clinical characteristics, and mortality among patients with myocardial infarction presenting without chest pain. Jama. 2000;283:3223-9.

7. Ryan TJ, Anderson JL, Antman EM, Braniff BA, Brooks NH, Califf RM, Hillis LD, Hiratzka LF, Rapaport E, Riegel BJ, Russell RO, Smith EE, 3rd, Weaver WD. ACC/AHA guidelines for the management of patients with acute myocardial infarction: executive summary. A report of the American College of Cardiology/American Heart Association Task Force on Practice Guidelines (Committee on Management of Acute Myocardial Infarction). Circulation. $1996 ; 94: 2341-50$.

8. Brush JE, Jr., Brand DA, Acampora D, Chalmer B, Wackers FJ. Use of the initial electrocardiogram to predict in-hospital complications of acute myocardial infarction. N Eng/ J Med. 1985;312:1137-41.

9. Lee TH, Rouan GW, Weisberg MC, Brand DA, Cook EF, Acampora D, Goldman L. Sensitivity of routine clinical criteria for diagnosing myocardial infarction within 24 hours of hospitalization. Ann Intern Med. 1987;106:181-6.

10. Gibler WB, Young GP, Hedges JR, Lewis LM, Smith MS, Carleton SC, Aghababian RV, Jorden RO, Allison EJ, Jr., Otten EJ, et al. Acute myocardial infarction in chest pain patients with nondiagnostic ECGs: serial CK-MB sampling in the emergency department. The Emergency Medicine Cardiac Research Group. Ann Emerg Med. 1992;21:504-12.

11. Alpert JS, Thygesen K, Antman E, Bassand JP. Myocardial infarction redefined -a consensus document of The Joint European Society of Cardiology/American College of Cardiology Committee for the redefinition of myocardial infarction. J Am Coll Cardiol. 2000;36:959-69. 
12. Mair $\mathrm{J}$, Thome-Kromer B, Wagner $\mathrm{I}$, Lechleitner $\mathrm{P}$, Dienstl $F$, Puschendorf $\mathrm{B}$; Michel $G$. Concentration time courses of tropomin and myosin subunits after acute myocardial infarction. Coron Artery Dis. 1994;5:865-72.

13. de Winter RJ, Koster RW, schotveld JH, Sturk A, van Straalen JP, Sanders GT. Prognostic value of troponin $T$, myoglobin, and CK-MB mass in patients presenting with chest pain without acute myocardial infarction. Heart. $1996 ; 75: 235-9$.

14. Glatz JF, Haastrup B, Hermens WT, de Zwaan C, Barker J, McNelll CJ, Adams $P$, Luscher $M$, Ravkilde J, Thygesen $K$, Kristensen $S$, Horder $M$. Fatty acidbinding protein and the early detection of acute myocardial infarction. The EUROCARDI multicenter trial. Circulation. 1997;96:1-215 (abstract).

15. Nakata $T$, Hashimoto $A$, Hase $M$, Tsuchihashi $K$, Shimamoto $K$. Human hearttype fatty acid-binding protein as an early diagnostic and prognostic marker in acute coronary syndrome. Cardiology. 2003;99:96-104.

16. Ishii $\downarrow$, Wang $J H$, Naruse $H$, Taga 5 , Kinoshita $M$, Kurokawa $H$, Iwase $M$, Kondo $T$, Nomura $M$, Nagamura $Y$, Watanabe $Y$, Hishida $H$, Tanaka $T$, Kawamura $K$. Serum concentrations of myoglobin ws human heart-type cytoplasmic fatty acid-binding protein in early detection of acute myocardial infarction. Clin Chem. 1997;43:1372-8.

17. Ghani $F$, Wu AH, Graff L, Petry $C$, Armstrong $G$, Prigent $F$, Brown M. Role of heart-type fatty acid-binding protein in early detection of acute myocardial infarction. Clin Chem. 2000;46:718-9.

18. Okamoto $F$, Sohmiya $K$, Ohkaru $Y$, Kawamura $K$, Asayama $K$, Kimura $H$,

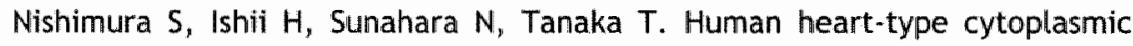
fatty acid-binding protein (H-FABP) for the diagnosis of acute myocardial infarction. Clinical evaluation of H-FABP in comparison with myoglobin and creatine kinase isoenzyme MB. Clin Chem Lab Med. 2000;38:231-8.

19. Antman EM, Tanasijevic MJ, Thompson B, Schactman M, McCabe CH, Cannon $C P$, Fischer GA, Fung AY, Thompson C, Wybenga D, Braunwald E. Cardiacspecific troponin I levels to predict the risk of mortality in patients with acute coronary syndromes. N Engl J Med. 1996;335:1342-9.

20. Hamm CW, Ravkilde J, Gerhardt W, Jorgensen $P$, Peheim $E$, Ljungdahl L, Goldmann B, Katus HA. The prognostic value of serum troponin $T$ in unstable angina. N Engl J Med. 1992;327:146-50.

21. Hamm CW, Goldmann BU, Heeschen $C$, Kreymann $G$, Berger $J$, Meinertz $T$. Emergency room triage of patients with acute chest pain by means of rapid testing for cardiac tropomin T or troponin I. N Engl J Med. 1997;337:1648-53.

22. Lindahl B, Venge $P$, Wallentin $L$. Relation between troponin $T$ and the risk of subsequent cardiac events in unstable coronary artery disease. The FRISC study group. Circulation. 1996;93:1651-7.

23. Ohman EM, Armstrong PW, Christenson RH, Granger CB, Katus HA, Hamm CW, OHanesian MA, Wagner GS, Kleiman NS, Harrell FE, Jr., Califf RM, Topol EJ. 
Cardiac troponin $T$ levels for risk stratification in acute myocardial ischemia. GUSTO IIA Investigators. N Engl J Med. 1996;335:1333-41.

24. Ravkilde $J$, Horder $M$, Gerhardt $W$, Ljungdahl $L$, Pettersson $T$; Tryding $N$, Moller $B H$, Hamfelt A, Graven T, Asberg A, et al. Diagnostic performance and prognostic value of serum troponin $T$ in suspected acute myocardial infarction. Scand J Clin Lab Invest. 1993;53:677-85.

25. Rozenman $Y$, Gotsman MS. The earliest diagnosis of acute myocardial infarction. Annu Rev Med. 1994;45:31-44.

26. Falk E. Coronary thrombosis: pathogenesis and clinical manifestations. Am $J$ Cardiol. $1991 ; 68: 28 \mathrm{~B}-35 \mathrm{~B}$.

27. Albrecht $S$, Kotzsch $M$, Siegert $G$, Luther T, Grossmann H, Grosser M, Muller $M$. Detection of circulating tissue factor and factor VII in a normal population. Thromb Haemost. 1996;75:772-7.

28. Francis JL, Carvalho $M$, Francis DA. The clinical value of tissue factor assays. Blood Coagul Fibrinalysis. 1995;6 Suppl 1:537-44.

29. Fareed J, Callas DD, Hoppensteadt D, Bermes EW, Jr. Tissue factor antigen levels in various biological fluids. Blood Coagul Fibrinolysis. 1995;6 Suppl 1:532-6.

30. Koyama $T$, Nishida $K$, Ohdama $S$, Sawada $M$, Murakami $N$, Hirosawa $S$, Kuriyama $R$, Matsuzawa $K$, Hasegawa $R$, Aoki N. Determination of plasma tissue factor antigen and its clinical significance. Br J Haematol. 1994;87:343. 7 .

31. Misumi $K$, Ogawa $H$, Yasue $H$, Soejima $H$, Suefuji $H$, Nishiyama $K$, Takazoe $K$, Kugiyama K, Tsuji I, Kumeda K, Nakamura S. Comparison of plasma tissue factor levels in unstable and stable angina pectoris. Am J Cardiol. 1998;81:226.

32. Miyamoto $S_{2}$ Ogawa $H$, Sakamoto $T$, Soejima $H$, Takazoe $K$, Shimomura $H_{3}$ Kajiwara I, Yoshimura $M$, Kugiyama $K$, Nakamura $S$, Ozaki $Y$. Platelet hyperaggregability persists even after the improvement of increased blood coagulation and impaired fibrinolysis with the stabilization of symptoms in patients with unstable angina. Int $J$ Cardiol. 2001;80:235+42.

33. Soejima $H$, Ogawa $H$, Yasue $H$, Kaikita $K$, Nishiyama $K$, Misumí $K$, Takazoe $K$, Miyao $Y$, Yoshimura $M$, Kugiyama $K$, Nakamura $S$, Tsujji I, Kumeda $K$. Heightened tissue factor associated with tissue factor pathway inhibitor and prognosis in patients with unstable angina. Circulation. 1999;99:2908-13.

34. Falciani $M$, Gori AM, Fedi $S$, Chiarugi L, Simonetti I, Dabizzil RP, Prisco D, Pepe $G$, Abbate R, Gensini GF, Neri Serneri GG. Elevated tissue factor and tissue factor pathway inhibitor circulating levels in ischaemic heart disease patients. Thromb Haemost. 1998; 79:495-9.

35. Gori AM, Pepe G, Attanasio M, Falciani M, Abbate R, Prisco D, Fedi S, Gilusti B, Brunelli T, Comeglio P, Gensini GF, Neri Serneri GG. Tissue factor reduction 
and tissue factor pathway inhibitor release after heparin administration. Thromb Haemost. 1999;81:589-93.

36. Marco $J$, Ariens RA, Fajadet J, Bossi IM, Marco I, Bernies M, Romano $S M_{\text {, }}$ Donatelli $F$, Brambilla $G M$, Somalvico $F$, Mari D, Gregorini L. Effect of aspirin and ticlopidine on plasma tissue factor levels in stable and unstable angina pectoris. Am I Cardiol. 2000;85:527-31.

37. Suefuji $H_{\text {; }}$ Ogawa $H$, Yasue $H$, Kaikita $K$, Soejima $H$, Motoyama $T$, Mizuno $Y$, Oshima S, Saito T, Tsuji I, Kumeda K, Kamikubo $Y$, Nakamura S. Increased plasma tissule factor levels in acute myocardial infarction. Am Heart $\mathrm{J}$. 1997; 134:253-9.

38. He $M$, Wen $Z$, He X, Xiong $S$, Liu $F, X u J$, Li $J$, Xie $Q$, Jian $Z$, Chen $F$, Xiao $B$, Pu $X$, He $S$. Observation on tissue factor pathway and some other coagulation parameters during the onset of acute cerebrocardiac thrombotic diseases. Thromb Res. 2002;107:223-8.

39. Yamamoto $N$, Ogawa $H$, Oshima S, Soejima $H$, Fujii $H$, Misumi K, Takazoe K, Mizuno $Y$, Noda K, Saito T, Tsuji I, Kumeda K, Nakamura S, Yasue $H$. The effect of heparin on tissue factor and tissue factor pathway inhibitor in patients with acute myocardial infarction. Int $J$ Cardiol. 2000;75:267-74.

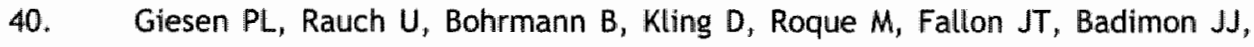
Himber $J$, Riederer $M A$, Nemerson $Y$. Blood-borne tissue factor: another view of thrombosis. Proc Natl Acad Sci U S A. 1999;96:2311-5.

41. Fukuda $C_{\text {, }}$ lijima $K$, Nakamura K. Measuring tissue factor (factor III) activity in plasma. Clin Chem. 1989;35:1897-900.

42. lijüma K, Fukuda $C$, Nakamura $K$. Measurements of tissue factor-like activity in plasma of patients with DIC. Thromb Res. 1991;61:29-38.

43. Nieuwland R, Berckmans RJ, Rotteveel-Eijkman RC, Maquelin KN, Roozendaal KJ, Jansen $P G$, ten Have K, Eijsman L, Hack CE, Sturk A. Cell-derived microparticles generated in patients during cardiopulmonary bypass are highly procoagulant. Circulation. 1997;96:3534-41.

44. Berckmans RJ, Nieuwland R, Boing AN, Romijn FP, Hack CE, Sturk A. Cellderived microparticles circulate in healthy humans and support low grade thrombin generation. Thromb Haemost. 2001;85:639-46. 




\section{CHAPTER 2}

\section{PLASMA MARKERS OF ACTIVATED BLOOD COAGULATION IN ACUTE CORONARY SYNDROMES}

RFM van der Putten, WT Hermens, JFC Glatz

Cardiovascular Research Institute Maastricht (CARIM), Maastricht University, Maastricht, the Netherlands

Submitted for publication 


\section{$>$ ABSTRACT}

Although there is compelling evidence for a major role of arterial thrombosis in the development of acute coronary syndromes (ACS), few studies have reported on the diagnostic value of hemostatic markers to detect ACS in a clinical setting, and even fewer have attempted to combine the diagnostic power of hemostatic markers with marker proteins for myocardial injury.

This review is a survey of studies that have evaluated plasma levels of coagulation markers in the early hours after onset of ACS. Studies were only included when blood sampling was performed on admission to the hospital, before antithrombotic or thrombolytic medication had been administered or revascularization procedures were initiated. Also, results obtained in ACS patients had to be compared with at least one control group.

Many studies have reported elevated levels of plasma markers of coagulation activation in the early hours after onset of ACS, and consequently, all these are potential diagnostic markers. However, only few studies actually indicated diagnostic power. In general, markers of coagulation activation are rapidly cleared from the circulation, and thus become less useful with longer periods after onset of ACS. In contrast, markers of myocardial necrosis are not detectable until a few hours after the acute event. Therefore, for ACS diagnosis independent of the admission delay of the patient, it could be useful to combine these markers. However, only a handful of studies have evaluated combinations of these markers with markers of myocardial necrosis.

The results from these studies are non-conclusive, and are difficult to compare because these studies differ in: (i) inclusion/exclusion criteria; (ii) definitions of acute myocardial infarction (AMII) and unstable angina pectoris (UAP); (iii) reference groups; (iv) assays and (v) cut-off values, that were used. The value of markers of activated coagulation, and particularly their combination with markers of myocardial necrosis, in the early diagnosis of ACS still needs to be elucidated in well-organized clinical trials considering large groups of patients. 


\section{INTRODUCTION}

Ever since the studies by Nossel et al. 1,2 in the mid-70's, in which a radioimmunoassay was described for the measurement of fibrinopeptide $A$ in plasma, a huge amount of studies have reported on plasma markers of activated coagulation in thrombotic disorders, such as the acute coronary syndromes (ACS). These markers have mainly been used to study the pathophysiology of ACS, to investigate and attempt to monitor the effects of anticoagulant or antithrombotic drugs, and to assess prognosis. Surprisingly, although there is compelling evidence for a major role of thrombosis in the development of ACS and their complications, few studies have reported on the sensitivity and specificity of hemostatic markers to detect ACS in a clinical setting.

This review will consider important studies that have evaluated activated coagulation in the early hours after onset of the acute coronary syndromes, and will focus on the potential clinical application of these markers in the early diagnosis of these patients. Therefore, only studies will be considered that fulfilled the following criteria:

i)

blood sampling was performed on admission to the hospital.

ii) blood sampling was performed before antithrombotic or thrombolytic medication had been administered or revascularization procedures were initiated.

iii) markers were measured in at least one control group for comparison, usually stable angina pectoris, non-cardiac chest pain, or healthy controls.

\section{PROTHROMBOTIC PATHWAYS IN ACUTE CORONARY SYNDROMES |<}

Atherosclerosis is the underlying cause of ACS and is characterized by a procoagulant state at all stages of the disease. Platelets and clotting factors circulate in their inactive forms. Thrombosis is a surface phenomenon, occurring at a site of vascular injury and involving platelet adhesion and aggregation followed by fibrin-mediated cross-linking. These two processes are complementary, but they also interact (Fig. 1).

\section{Platelet activation}

As described by Selwyn et al. ${ }^{3}$, plaque rupture or erosion exposes glycoprotein components of the subendothelial membrane, such as collagen. These components mediate platelet adhesion ${ }^{4}$. Under conditions of high shear stress, characteristic of the coronary vasculature particularly at partially occluded sites, interaction of von Willebrand Factor (VWF) with the platelet 
surface glycoprotein $\mathrm{lb} / \mathrm{IX}$-V-receptor complex primarily mediates platelet adherence to collagen, although other collagen-specific receptors on the platelet surface, such as glycoprotein $\mathrm{la} / \mathrm{lla} \mathrm{a}_{1} \mathrm{IV}$, and $\mathrm{VI}$, facilitate this process 4,5 . Under conditions of low shear stress, characteristic of diseased arteries, platelets may also use other glycoproteins, such as fibrinogen and fibronectin, to adhere to the subendothelium ' 6 . Subsequently, agonists, such as epinephrine, thrombin, adenosine 5'-diphosphate (ADP), collagen, and WWF, as well as high shear stress and other local mechanical stimuli are capable of activating adherent platelets. Platelet activation exposes the platelet glycoprotein IIb/llla receptor, a binding site with a high affinity for fibrinogen. This allows recruitment of platelets via fibrinogen linkages and results in local platelet aggregation and a growing thrombus.

Activated platelets also release a large number of biologically active substances that promote thrombus formation, plaque growth, and restenosis. Molecules, such as thromboxane $A_{2}$, serotonin, ADP, and epinephrine, stimulate further platelet aggregation and activation. Thromboxane $A_{2}$ and serotonin also stimulate smooth muscle cell proliferation ${ }^{7}$. P-selectin is involved in formation of platelet-monocyte aggregates, which in turn can induce expression of inflammatory mediators ${ }^{8}$. Platelet-derived interleukin-1 increases synthesis of interleukin-6 and interleukin-8 from natural killer cells, which are important mediators of inflammation ${ }^{9}$. Platelets are also a source of reactive oxygen species, which may contribute to the inflammatory processes 10,11 . Platelet factor 4 , initially found to be involved in the coagulation cascade, has more recently been found to induce production of the inflammatory cytokine interleukin-8 from natural killer cells ${ }^{12}$. Factor $V$ is also an important coagulation protein released by activated platelets ${ }^{13}$.

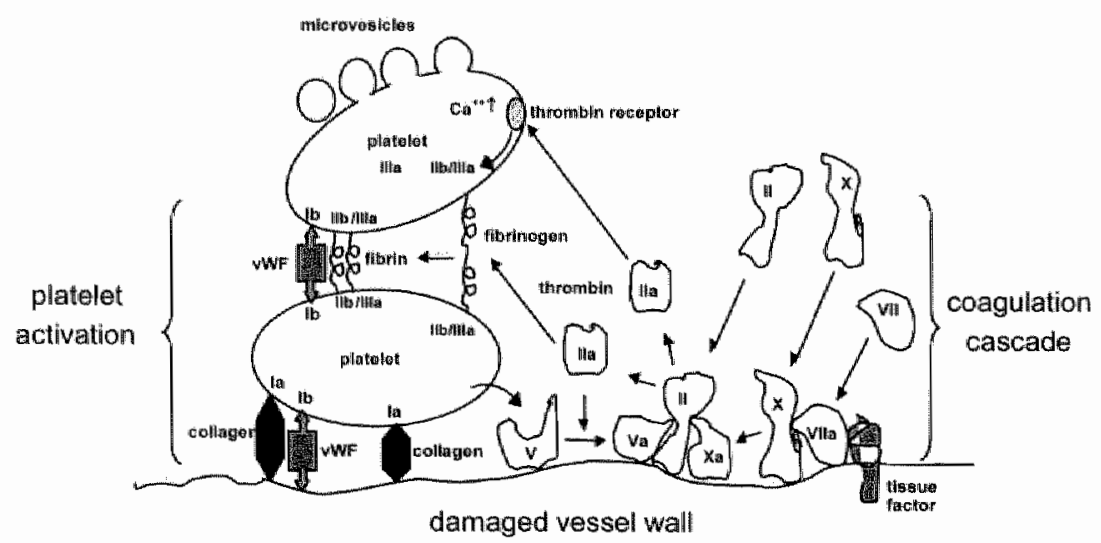

Figure 1. Schematic presentation of the interaction of platelet activation and coagulation activation in thrombus formation. 
Recently, platelets have been found to contain tissue factor (TF), the initiator of the blood coagulation cascade, its main intraplatelet locations being the $\alpha$-granules and the open cannalicular system ${ }^{14}$. Following activation with strong platelet activators such as thrombin, TF was found to be exposed on the platelet cell membrane. The origin of platelet TF is still unknown. Since no mRNA could be detected in platelets ${ }^{15}$, it was hypothesized that platelets internalize TF originating from other cells. Activated monocytes have been proposed as candidates, since they can transfer TF onto platelets via microparticle transfer ${ }^{16}$, however, unphysiological conditions have to be applied in vitro in order to induce the shedding of microparticles from these cells.

A key factor in platelet activation is the transfer of anionic phospholipids; which are normally confined to the inner platelet membrane, to the outer membrane (flip-flop). This allows circulating coagulation factors like factor VII, IX, X, and II to bind to the membrane, and produce thrombin as will be described below. In its turn, thrombin is a potent platelet activator, resulting in more potential binding sites for coagulation factors.

To summarize, platelets are activated by various cardiovascular risk factors and use multiple pathways to interact with local thrombogenic sites on atherosclerotic plaques. A sequence of mechanisms then determines the extent of local thrombus formation.

\section{Coagulation}

This pathway comprises the sequential activation of a family of coagulation factors, resulting in conversion of fibrinogen into fibrin monomers, which cross-link to stabilize the platelet-rich thrombus and, ultimately form a solid clot (Fig. 1).

Tissue factor, the most potent initiator of the blood clotting system, is an integral membrane protein that is normally found outside the vasculature ${ }^{17}$. in contrast, the proteins that constitute the rest of the blood clotting cascade circulate largely as soluble proteins in the plasma. Vascular injury results in the exposure of TF to the blood, whereupon it binds factor VII or factor VIla with high affinity and specificity. A novel hypothesis, in which TF present in circulating blood may participate in hemostasis and thrombosis, was presented by Giesen et al. ${ }^{18}$.

Within the human blood, monocytes are the only cell type that can be induced to synthesize TF de novo. This is effectively promoted by lipopolysaccharide (LPS) both in vitro and in vivo ${ }^{19}$. Under physiological conditions, these cells do probably not express TF. However, when monocytes are stimulated under appropriate conditions, they will express TF and may initiate coagulation after appropriate 'deencryption' of TF activity ${ }^{20}$. TF is 
also present in platelets, its main intraplatelet locations being the a-granules and the open cannalicular system ${ }^{14}$.

In the plasma compartment, TF is at least in part associated with microvesicles ${ }^{14}$. They are known to be released from the plasma membrane of cells under various conditions, including mechanical stress, cell activation, and apoptosis. TF can be found in microvesicle-free supernatant of plasma 21,22 (soluble TF). Since soluble TF is considered to be a less active initiator of blood coagulation than full-length TF ${ }^{23}$, microvesicle-associated TF most likely represents the potentially active form of TF in plasma. However, in the absence of any other blood component, the functional competence of TF exposed on the cell membrane of activated platelets ${ }^{15,24}$, or on isolated microparticles seems to be limited ${ }^{25}$.

Taken together; under physiological conditions, functional TF might be mainly associated with platelets and circulating microvesicles ${ }^{14,15,18}$. Under pathological conditions, however, the blood localization pattern of TF may be markedly different. After prolonged stimulation periods (e.g., > $60 \mathrm{~min}$ ), monocyte based TF could become increasingly important as an initiator of thrombosis, whereas in physiological thrombus formation and in the initial phase of the development of intravascular thrombosis, TF associated with platelets and microvesicles might be more important ${ }^{26}$.

Although the vast majority of factor VII in plasma circulates as the zymogen, all normal individuals have been found to have low levels of factor VIla in their plasma (about $1 \%$ or less of total factor VII) ${ }^{27}$. Once bound to TF, factor VII is rapidly converted to factor VIla via limited proteolysis ${ }^{28}$.

As previously described by Morrissey ${ }^{17}$, there are two ways the TF-VIla complex can form: through direct capture of factor VIla by TF, or through capture of factor VII by TF followed by conversion of bound factor VII to VIla. A number of proteases have been shown to activate factor VII to VIla in vitro, including factors $\mid \mathrm{Xa}, \mathrm{Xa}, \mathrm{X} \| \mathrm{la}$, thrombin and plasmin ${ }^{28-34}$. In addition, the TFVIla complex can itself catalyze the activation of factor VII bound to TF, via an auto-activation reaction 35,36 . It is currently unclear which of these proteases plays the major role in activating TF-bound factor VII during clotting. In any case, it appears that trace levels of factor VIla in the circulation may serve to prime the clotting cascade, by providing the initial source of active protease (TF-VIla) following exposure of TF to the blood.

Once the TF-VIla complex forms, it triggers the blood coagulation cascade in two ways (Fig. 2). In the first mechanism, TF-Vlla directly activates factor $X$ to Xa (pathway 1). In the second mechanism, TF-VIla activates factor IX to IXa via limited proteolysis (pathway 2). The newly generated factor IXa assembles on a phospholipid surface with its protein cofactor, factor VIIla, where it catalyzes the activation of factor $X$ to $X$ a. Which pathway dominates in vivo may depend on local factors. Newly formed factor $X a$ assembles on a 
phospholipid surface with its cofactor (factor Va) to catalyze the conversion of prothrombin (factor II) to thrombin (factor Ila), the most important protein in the coagulation cascade.

Actions of thrombin include (1) conversion of fibrinogen to fibrin ${ }^{37}$; (2) conversion of factor VIII to VIIIa, which in turn can form an active complex with factor $\mid \mathrm{Xa}^{38}$; (3) conversion of factor XIII to XIIIa, the protein that converts soluble fibrin into an insoluble cross-linked matrix ${ }^{37}$; and (4) conversion of factor $\mathrm{V}$ to $\mathrm{Va}$, an essential cofactor for conversion of prothrombin to thrombin ${ }^{38}$; (5) platelet activation which results in release of factor $V$ from platelets ${ }^{38,39}$; (6) conversion of factor $X I$ to $X l a$, a positive feedback loop that is only important at very low TF concentrations (i.e., 1-20 $\mathrm{pg} / \mathrm{mL})^{40,41}$. When both thrombin and collagen are present, the degree of platelet activation is greater than that achieved with either agonist alone ${ }^{39}$. The amount of thrombin formed during the initial phase of the cascade is insufficient for formation of significant amounts of fibrin. However, the positive feedback loops described above and the formation of $|\mathrm{Xa} / \mathrm{V}| \mathrm{lll}$ a and $\mathrm{Xa} / \mathrm{Va}$ complexes on the surface of activated platelets amplify the cascade and produce a solid, cross-linked fibrin clot ${ }^{42}$.

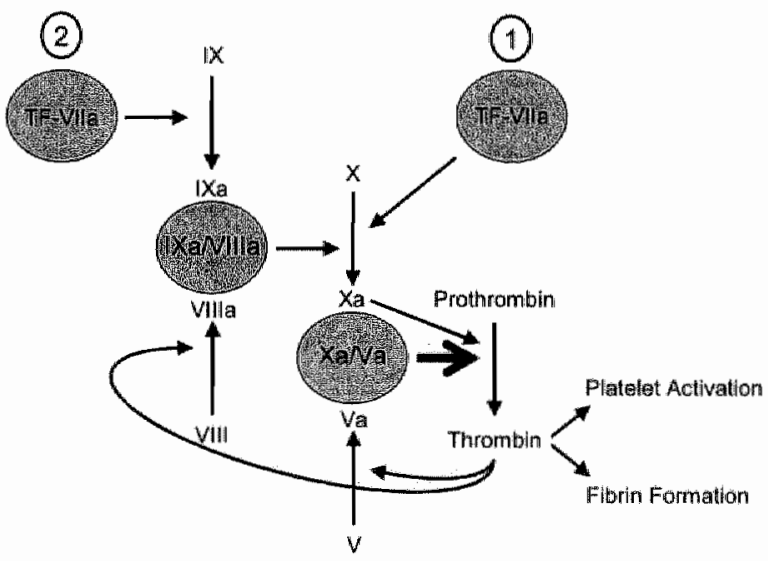

Figure 2. Initiation of the blood clotting cascade by TF-Vlla. The TF-Vlla complex triggers the blood clatting cascade in two ways: (1) by directly actiwating factor $X_{\text {; }}$ and (2) by activating factor $1 X_{1}$ to $1 X_{a}$, which in turn activates factor $X$ in the presence of factor villa, its cofactor. All these reactions occur on phosphotipid membranes. Newly formed factor $X a$ assembles on a phospholipid membrane with its protein cofactor ffactor Wa) to catalyze the conversion of prothrombin to thrombin. Subsequently, thrombin converts fibrinogen into fibrin by limited proteolysis, and fibrin polymerizes to form a gel, or fibrin clot. Thrombin is also a potent platelet activator. Factor Va and VIlla circulate as inert precursors (factor $V$ and Wili, respectively), which are activated by timited proteolysis, catalyzed by thrombin and/or factor $X a$. In this simplified clotting cascade, factors XI and XIII, as well as all of the anticoagulants have been omitted. 
The pathway triggered by tissue factor is referred to as the extrinsic pathway. A second branch of the coagulation cascade (the intrinsic pathway, or contact activation) is triggered by conversion of factor XII to Xlla on negatively charged surfaces, and ultimately leads to conversion of factor $I X$ to IXa. A few studies reported lower factor XII activity combined with lower levels of high molecular weight kininogen (HMWK) in ACS ${ }^{43-46}$, suggesting intrinsic pathway activation. Higher factor $X \mid$ activity was also observed in AMI 43,45,47. Minnema et al. ${ }^{47}$ found factor Xla-C1 inhibitor complexes, which reflect acute activation of factor $X I$, in $24 \%$ of the patients with $A M I, 8 \%$ of the patients with UAP, and $4 \%$ of the patients with SAP, whereas factor Xlaalpha(1)-antitrypsin complexes, which reflect chronic activation, were observed equally in all 3 study groups. Factor Xila- or kallikrein-C1 inhibitor complexes were not increased. However, since these zymogens are also cleaved to their active species by thrombin " ${ }^{48}$ they may participate in feedback thrombin generation, but they do probably not serve as primary initiator of arterial thrombosis in ACS.

\section{> ANTITHROMBOTIC PATHWAYS IN ACUTE CORONARY SYNDROMES}

As described by Selwyn et al. ${ }^{3}$, antithrombin (AT) is a circulating glycoprotein that is primarily synthesized in the liver and binds to proteases of the coagulation cascade. Its most important effect is inactivation of thrombin, but it also inactivates factors IXa, Xa, Xla, and Xlla ${ }^{49,50}$ (Fig. 3). Formation of a complex between antithrombin and exogenously administered heparins (or the heparin-like glycosaminoglycans in the vascular wall) greatly increase the activity of antithrombin. Also, heparin cofactor II circulates in plasma and binds to thrombin ${ }^{51}$. Heparin is a necessary cofactor, but the activity of heparin cofactor II-heparin complexes is much less than that of antithrombinheparin complexes. Thrombomodulin (TM) is expressed on endothelial cell surfaces and binds thrombin, thereby decreasing thrombin activity. The thrombin-thrombomodulin complex also activates protein $C$, a circulating glycoprotein that is synthesized in the liver ${ }^{52}$. Activated protein $C$ inhibits factors $\mathrm{Va}$ and VIIla, an effect that is enhanced by protein $\mathrm{S}$, a cofactor expressed by endothelial cells ${ }^{53,54}$. Tissue factor pathway inhibitor (TFPI) is released by endotheliall cells and platelets and circulates bound to plasma lipoproteins. It inhibits the procoagulant effects of TF-VIla complex and factor $\mathrm{Xa}^{55}$.

Tissue-type plasminogen activator (t-PA) or urinary-type plasminogen activator (U-PA) converts plasminogen to the fibrin-degrading protease plasmin ${ }^{56}$. In the absence of fibrin, conversion of plasminogen to plasmin is slow. However, binding of t-PA to the fibrin surface greatly accelerates the 
process. Degradation of fibrin exposes more t-PA binding sites via a positive feedback mechanism that accelerates clot lysis ${ }^{57}$. Cross-linking of fibrin by factor XIlla masks $t$-PA binding sites, protecting fibrin from degradation ${ }^{58}$. Inhibitors of plasminogen activation, especially plasminogen activator inhibitor-1 (PAl-1), also contribute to opposing the fibrinolytic activity of t-PA and U-PA. Plasminogen activator inhibitor-1 binds to these fibrinolytic activators to form a stable complex, which is rapidly cleared by the liver ${ }^{59,60}$. More recently, thrombin-activatable fibrinolysis inhibitor (TAFI), another potent t-PA inhibitor, was identified. TAFI is a carboxypeptidase that cleaves carboxyterminal residues within fibrin, which results in loss of plasmin and tPA binding sites ${ }^{61}$. TAFI is activated by thrombomodulin and is inactivated by the protein $\mathrm{C}$-protein $S$ complex ${ }^{62}$.

\section{PATHOPHYSIOLOGY OF ACUTE CORONARY SYNDROMES}

In coronary artery disease, thrombosis is triggered by rupture of atherosclerotic plaques ${ }^{63}$. Within the plaque, the lipid-rich core has been shown to be the most thrombogenic component. It contains TF, in particular associated with microparticles ${ }^{64}$, and high levels of procoagulant microparticles were found in the circulating blood of patients with ACS ${ }^{65}$. TF has been shown to be differentially expressed in coronary atherectomy specimens from patients with acute coronary syndromes ${ }^{66,67}$. Expression of TF on macrophages was more frequent in coronary atherosclerotic plaques in patients with unstable angina than in those with stable angina ${ }^{68}$.

As described by Davies ${ }^{69}$, almost all acute myocardial infarctions (AMI) are caused by thrombosis developing on a coronary atherosclerotic plaque. The rare exceptions to this are the spontaneous coronary artery dissection, coronary arteritis, coronary emboli, and coronary spasm. Thrombosis is also the major initiating factor in unstable angina pectoris (UAP), particularly when rest pain is recent and increasing in severity. Necropsy studies suggest that a new thrombotic coronary event underlies $50-70 \%$ of acute sudden cardiac deaths.

Thrombosis on plaques occurs because of two somewhat different processes: (a) In 33\% of ACS, particularly in acute sudden cardiac death, there is no disruption of a plaque but just a superficial erosion of a markedly stenotic and fibrotic plaque ${ }^{70}$. Thrombus formation in cases without plaque disruption may depend on a hyperthrombotic state triggered by systemic factors; (b) plaque disruption (rupture, fissuring). Here the plaque cap tears to expose the lipid core to blood in the arterial lumen. The core area is highly thrombogenic, containing tissue factor, fragments of collagen, and crystalline surfaces to accelerate coagulation. Thrombus forms initially in the plaque 
itself, which is expanded and distorted from within, and may subsequently extend into the arterial lumen.

The thrombi which occur either in disruption or in erosion circumstances are dynamic and evolve in stages. In disruption, the initial stage occurs within the lipid core itself and predominantly consists of adherent platelets ${ }^{71-75}$. As the thrombus begins to extend into the lumen the fibrin component increases, but any surface exposed to the blood in the lumen will be covered by activated platelets. While flow continues over this exposed thrombus, clumps of activated platelets are released into the distal intramyocardial arteries as microemboli. The thrombus may grow to occlude the artery, leading to a final stage in which there is a loose network of fibrin containing large numbers of entrapped red cells. This thrombus may propagate distally after the onset of myocardial infarction. Furthermore, it has a structure making it very susceptible to either natural or therapeutic lysis, but this will expose the deeper and earlier thrombus which is more resistant to lysis.

Transmural acute myocardial infarction is caused by a coronary artery occlusion which develops within a few hours and persists for at least 6-8 hours. The infarcted tissue is structurally suggestive of a homogeneous entity; all the myocardium involved died around the same time. Autopsy data on 91 cases of fatal transmural infarction showed that about $80 \%$ of occlusive thrombi consist predominantly of fibrin, which is a favourable substrate for thrombolytic therapy ${ }^{76}$.

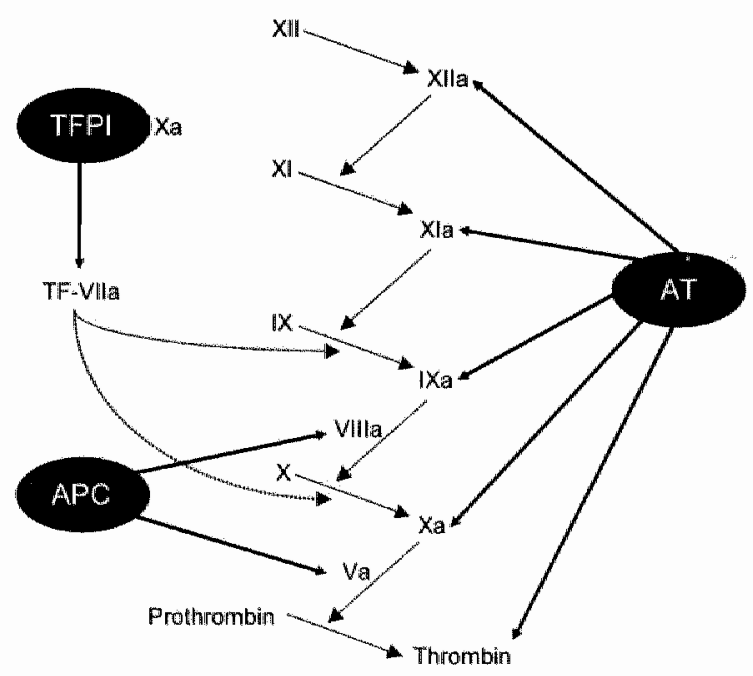

Figure 3. Coagulation pathway and important inhibitor systems. APC = activated protein $C, A T=$ antithrombin, TFP! = tissue factor pathway inhibitor. 
Non-transmural infarctions (non-Q-wave) have a different structure which is built up by the coalescence of many small areas of necrosis formed at different times. This pattern of necrosis characteristically follows crescendo unstable angina and appears to be caused by repetitive episodes of short-lived occlusion or platelet embolisation, or both. A further factor in limiting the spread of necrosis and preserving the subpericardial zone is the existence of prior collateral flow in the affected myocardium. Unstable angina is caused by disrupted plaques with exposed mural thrombus and retention of flow in the artery. This feature of some persistent flow is all that separates the vascular lesion of unstable angina from that of acute myocardial infarction. Platelet emboli into the myocardium cause microscopic foci of necrosis which are the basis of the increased concentrations of troponin $T$ found in the blood in a proportion of cases of unstable angina.

The TIMI IIIA trial showed that fresh fibrin-rich thrombi were more prevalent among patients with non-Q-wave infarction than in patients with unstable angina, however, neither patients with unstable angina nor non-Qwave infarction benefited clinically from fibrinolytic therapy ${ }^{77}$. Conversely, blockade of platelet aggregation with GP $\mathrm{llb} / \mathrm{lll}$ a inhibitors, invariably reduced death or nonfatal infarction at 30 days in both groups ${ }^{78}$. These findings are consistent with autopsy studies that point to the formation of platelet thrombi as a central pathogenetic mechanism in both of these unstable syndromes.

\section{MARKERS OF COAGULATION ACTIVATION IN THE ACUTE PHASE $\mid<$ OF ACS}

\section{P-selectin}

The adhesion molecule P-selectin plays an important role in modulating interactions between blood cells and the endothelium. It is a component of the membrane of the a-granules and dense granules of platelets, and also of the membrane of the Weibel-Palade bodies of endothelial cells ${ }^{79}$.

Since P-selectin is only expressed on activated cells ${ }^{80}$, perhaps its most important clinical use is as a marker of platelet activation. Previously, plasma markers, such as B-thromboglobulin and platelet factor 4, were studied. However, the ease of flow cytometry has put this technique, which can be used to determine the presence of P-selectin on the platelet surface (platelet-associated P-selectin), in the foreground. The development of monoclonal antibody based ELISAs has allowed the quantification of P-selectin in plasma (soluble P-selectin). There has been a considerable debate whether or not raised plasma levels of P-selectin reflect endothelial dysfunction, platelet activation, or both. It now seems clear that most, if not all, of the measured P-selectin in plasma is of platelet origin. However, there is not yet 
consensus on the issue whether or not soluble P-selectin levels reflect some aspect of platelet function or activity ${ }^{81,82}$.

Immunohistochemical analysis of surgically-excised and post mortem human atherosclerotic plaques has shown strong expression of P-selectin by the endothelium overlying active atherosclerotic plaques and fatty streaks. In contrast, P-selectin was not detected in normal arterial endothelium or in endothelium overlying inactive fibrous plaques ${ }^{83}$. Tenaglia et al. ${ }^{84}$ reported significantly greater P-selectin staining on atherectomy specimens from patients with unstable angina than from patients with stable angina.

Some studies have shown that soluble P-selectin levels ${ }^{85,86}$ and plateletassociated P-sellectin ${ }^{86}$ are elevated in the acute phase of UAP. Soluble $P$. selectin antigen ${ }^{86}$ and platelet-associated P-selectin ${ }^{86}$ levels were also found to be elevated in the acute phase of AMI. Malý et al. ${ }^{87}$ found that plasma levels of soluble P-selectin were only slightly, but not significantly higher in patients with unstable angina pectoris and stable coronary artery disease than in patients with acute myocardial infarction or normal subjects.

Also, several studies reported that high soluble ${ }^{88,89}$ and platelet-bound P. selectin ${ }^{86}$ values on admission were associated with an increased risk at acute cardiac events in patients with acute coronary syndrome. Hollander et al. ${ }^{90}$ assessed the value of soluble and membrane P-selectin in identifying patients with acute coronary syndromes, concluding that based on sensitivites and specificities, neither has any advantage over CK-MB. However, Hillis et al. ${ }^{91}$ concluded that both soluble P-selectin and troponin I were independent predictors of the 38 from 126 patients with chest pain thought clinically to represent myocardial ischemia who subsequently experienced a serious event. Two other studies did not find any additional value in the measurement of soluble P-selectin ${ }^{92,93}$, however, since these studies both measured soluble P. selectin in serum, comparisons to the other studies who used citrated plasma, can likelly not be drawn. Serebruany et al. ${ }^{94}$ measured six markers (troponin I, CK, CKMB, myoglobin and soluble and platelet-bound P-selectin) in 122 patients presenting with chest pain. In multivariate analysis, myoglobin and platelet-bound P-selectin predicted cardiac origin and AMI, whereas myoglobin and soluble P-selectin predicted heart failure.

In summary, although some data suggest that increased P-selectin levels can be found in the acute phase of patients with ACS, and may predict adverse outcome, it is unclear if this marker provides better prognostic information than other, more established markers, such as $C K-M B, C$-reactive protein, or even than classical risk factors such as hypercholesterolemia or smoking. 


\section{Tissue factor}

Tissue factor is an integral membrane glycoprotein which is recognized as the major physiologic initiator of blood coagulation. TF forms a complex with plasma factor VIla forming a potent procoagulant which can rapidly activate factor IX and X (Fig. 2). Several enzym-linked immunosorbent assays (ELISAs) have been described to measure TF antigen levels in plasma ${ }^{21,95-98}$. Since there is no international standard, these ELISAs commonly use a recombinant non-lipidated TF as standard. However, the validity of using such a standard is not yet fully established, since different TF entitities may circulate in plasma.

\section{Table 1. TF antigen in plasma of patients with ACS}

\begin{tabular}{|c|c|c|c|c|}
\hline Reference & $\begin{array}{c}\text { Subjects } \\
\text { (number) }\end{array}$ & $\begin{array}{c}\text { Most recent } \\
\text { attack }\end{array}$ & $\begin{array}{c}\text { TF antigen } \\
(\mathrm{pg} / \mathrm{mL})\end{array}$ & Assay \\
\hline $\begin{array}{l}\text { Suefujij, } \\
1997 \% \%\end{array}$ & $\begin{array}{l}\operatorname{NCCP}(27) \\
\text { SEA (27) } \\
\text { AMI (31) }\end{array}$ & $<6 \mathrm{~h}$ & $\begin{array}{c}177 \pm 37 \\
184 \pm 46 \\
240 \pm 112^{*}\end{array}$ & Kalketsukene ELISA \\
\hline $\begin{array}{l}\text { Misumi, } \\
1998^{104}\end{array}$ & $\begin{array}{l}\operatorname{NCCP}(27) \\
\text { SEA (27) } \\
\text { UAP }(21)\end{array}$ & $\begin{array}{l}\geq 4 \text { weeks } \\
<24 \mathrm{hl}\end{array}$ & $\begin{array}{l}177 \pm 37 \\
184 \pm 46 \\
240 \pm 75^{*}\end{array}$ & Kaketsuken@ ELISA \\
\hline $\begin{array}{l}\text { Falciani } \\
1998^{87}\end{array}$ & $\begin{array}{l}\text { CTRL (48) } \\
\text { SAP (24) } \\
\text { UAP (18) } \\
\text { AMI }(13)\end{array}$ & $6-12$ months & $\begin{array}{c}143(28-255) \\
182(73-380)^{\star} \\
256(149-834)^{\star} \\
214(125-342)^{\star}\end{array}$ & ImubindB ELISA \\
\hline $\begin{array}{l}\text { Soejima, } \\
1999^{106}\end{array}$ & $\begin{array}{l}\text { NCCP (55) } \\
\text { SEA (56) } \\
\text { UAP (51) }\end{array}$ & $<24 h$ & $\begin{array}{r}180 \pm 30 \\
189 \pm 30 \\
238 \pm 54^{*}\end{array}$ & Kaketsuken(i) ELISA \\
\hline $\begin{array}{l}\text { Gori, } \\
1999 \text { 107 }\end{array}$ & $\begin{array}{l}\text { CTRL (28) } \\
\text { UAP (28) }\end{array}$ & $<24 \mathrm{~h}$ & $\begin{array}{c}139(28-200) \\
255(135-380)^{\star}\end{array}$ & Imubind(B ELISA \\
\hline $\begin{array}{l}\text { Marco, } \\
2000 \text { 100 }\end{array}$ & $\begin{array}{l}\text { SAP }(20) \\
\text { UAP }(20)\end{array}$ & NR & $\begin{array}{c}193 \pm 95 \\
553 \pm 91^{*}\end{array}$ & Imubind(B ELISA \\
\hline $\begin{array}{l}\text { Yamamoto, } \\
2000^{\text {tia }}\end{array}$ & $\begin{array}{l}\operatorname{NCCP}(25) \\
\text { SEA }(26) \\
\text { AMI }(26)\end{array}$ & $3.4 \pm 0.4 \mathrm{~h}$ & $\begin{array}{c}180 \pm 29 \\
190 \pm 30 \\
248 \pm 117^{*}\end{array}$ & Kaketsukend ELISA \\
\hline $\begin{array}{c}\text { He } \\
2002\end{array}$ & $\begin{array}{c}\text { CTRL }(50) \\
\text { AIS }(71) \\
\text { AMI }(69)\end{array}$ & $\begin{array}{l}<24 \mathrm{~h} \\
<24 \mathrm{~h}\end{array}$ & $\begin{array}{c}23 \pm 7 \\
31 \pm 14^{*} \\
39 \pm 24^{*}\end{array}$ & Laboratory ELISA \\
\hline $\begin{array}{l}\text { Maly, } \\
2003^{8}\end{array}$ & $\begin{array}{l}\text { CTRL }(10) \\
\text { SAP }(17) \\
\text { UAP }(23) \\
\text { AMI }(10)\end{array}$ & $<12 \mathrm{~h}$ & $\begin{array}{l}125 \pm 32 \\
120 \pm 45 \\
131 \pm 58 \\
129 \pm 30\end{array}$ & Imubind ELISA \\
\hline
\end{tabular}

Values are given as mean \pm SD or as median with total range in brackets. AlS indicates acute ischemic stroke; AMI, acute myocardial infarction; CTRL, control subjects: NR, not reported; SAP, stable angina pectoris; SEA, stable exertional angira; and UAP, unstable angina pectoris. "Values that are significantly different from the values measured in the first mentioned group of the corresponding study. 
Furthermore, it is unknown whether these assays detect alternatively-spliced human $T F$, which was only recently discovered by Bogdanov and co-workers ${ }^{22}$. Normal plasma levels of TF antigen measured with these assays have roughly been reported between $100-200 \mathrm{pg} / \mathrm{mL}^{99-101}$. The interpretation of plasma TF antigen assays is complicated by the fact that it is not clear whether TF is in functional form. Since TF requires association with procoagulant phospholipids for its activity, soluble TF in plasma may not reflect the potential for clotting activation ${ }^{23}$.

Another unresolved issue is the removal of plasma TF from the circulation and therefore its half-life. The presence of TF in urine ${ }^{101}$ tempts to speculate that TF is cleared by the kidney, however, the molecule is possibly too large to allow filtration by the undamaged glomerulus ${ }^{102}$. Also plasma TF levels in patients with renal failure not receiving hemodialysis were normal ${ }^{21}$. In normal kidney, TF seems to be localized to glomerular epithelium and basement membranes ${ }^{103}$. It has been hypothesized that either renal macrophages or tubular cells themselves become activated in malignant states and certain inflammatory diseases to secrete increased amounts of urinary TF.

A number of studies, summarized in Table 1, reported increased plasma TF antigen levels in the acute phase in patients with unstable angina $97,104-108$ and myocardial infarction ${ }^{96,109,110}$. One study ${ }^{87}$ reported normal TF antigen levels in AMI and UAP. Remarkably, the ELISA that was used by He et al. ${ }^{109}$ measured much lower TF antigen levels in control subjects $(-25 \mathrm{pg} / \mathrm{mL})$ than the other ELISAs. They did not report any assay details. Falciani et al. ${ }^{97}$ found increased plasma TF antigen levels in patients with a previous history of AMI, patients with UAP and effort angina, but found that TF antigen levels between the groups were not different.

Table 2. TF activity in plasma or wholle blood from patients with ACS

\begin{tabular}{|c|c|c|c|c|}
\hline Reference & $\begin{array}{l}\text { Subjects } \\
\text { (number) }\end{array}$ & $\begin{array}{c}\text { Most recent } \\
\text { attack }\end{array}$ & TF activity & $\begin{array}{l}\text { Assay } \\
\text { (units) }\end{array}$ \\
\hline $\begin{array}{c}\text { Wielders, } \\
1997^{116}\end{array}$ & $\begin{array}{l}\text { CTRL }(2 B) \\
\text { DVT (21) } \\
\text { CAD }(31)\end{array}$ & NR & $\begin{array}{c}354 \pm 57 \\
459 \pm 130^{*} \\
390 \pm 70^{*}\end{array}$ & $\begin{array}{l}\text { Endogenous Thrombin } \\
\text { Potential }(E T P)=\text { area under } \\
\text { thrombin generation curve } \\
(\mathrm{nmol} \cdot \mathrm{min} / \mathrm{L})\end{array}$ \\
\hline $\begin{array}{l}\text { Santucei, } \\
2000^{111}\end{array}$ & $\begin{array}{l}\text { CTRL (30) } \\
\operatorname{UAP}(13)\end{array}$ & NR & $\begin{array}{l}474 \pm 98 \\
284 \pm 86^{*}\end{array}$ & $\begin{array}{l}\text { Clotting time in } \\
\text { whole-blood (AU) }\end{array}$ \\
\hline $\begin{array}{c}\text { He" } \\
2002^{109}\end{array}$ & $\begin{array}{l}\text { CTRL (50) } \\
\text { AIS }(71) \\
\text { AMI }(69)\end{array}$ & $\begin{array}{l}<24 h \\
<24 h\end{array}$ & $\begin{array}{l}2.2(11.6-5.9) \\
4.7(2.8-6.5)^{4} \\
5.7(4.9-40.4)^{*}\end{array}$ & $\begin{array}{l}\text { Method of Fukuda et al., } \\
\text { 1989 } \\
\text { plasma }+ \text { II }+ \text { VII }+ \text { IX }+X \text { (AU) }\end{array}$ \\
\hline
\end{tabular}

Values are given as nean \pm SD or as median with total range in brackets. Als indicates acute ischemic stroke; AMI, aculte myocardial infarction; AU, arbitrary units; CAD, coronary artery disease; DVT, deep wenous thrombosis; NR, not reported; and UAP, unstable angina pectoris. "Values that are significantly different from the values measured in the first menthoned group of the corresponding study. 
Suefuji et al. ${ }^{96}$ found that plasma TF antigen levels $(<6 \mathrm{~h}$ from onset of symptoms) were higher in AMI patients with a history of prodromal unstable angina than in patients with a sudden onset of infarction. In addition, TF levels decreased to approximately the control group level in the chronic phase (2 weeks from admission) in AMl with sudden onset, but remained high in AMI with prodromal unstable angina. These results suggest that increased procoagulant activity may be associated with repeated episodes of myocardial ischemia and reperfusion. Soejima et al. ${ }^{106}$ found that in UAP patients, elevated TF levels on admission were an important predictor of unfavourable outcome during the $17.0 \pm 6.5$ month follow-up period.

The role of circulating TF remains poorly understood due to the limited availability of assays capable of measuring circulating procoagulant activity (Table 2). TF activity levels measured in whole-blood with a clotting time assay were found to be increased in patients with UAP ${ }^{111}$. For measurement of TF activity in plasma a chromogenic assay has been described ${ }^{112,113}$, but this method requires prior preparation of the euglobulin fraction and is difficult to reproduce ${ }^{101}$. Using this assay, He et al. ${ }^{109}$ reported increased plasma TF activity in plasma from AMI patients. Others have developed assays to measure TF activity on microparticles ${ }^{114}$ or on lysed whole-blood ${ }^{115}$, however, to our knowledge, these assays have not been used to assess TF activity in ACS patients.

In conclusion, although TF antigen levels seem to be elevated in the acute phase of ACS, which makes TF antigen a potentially useful early marker for ACS, none of these studies reported on sensitivities and specificities. Also, one study has shown increased TF activity, which may more accurately reflect in vivo thrombogenicity, but the value of plasma TF activity as an early marker for ACS remains to be elucidated.

\section{Tissue factor pathway inhibitor}

Tissue factor pathway inhibitor (TFPl) plays a key role in the regulation of TF-initiated blood coagulation via its abilities to directly inhibit factor $\mathrm{Xa}$ and to inhibit the proteolytic activity of the TF-Vlla complex by forming a quaternary complex: TF-VIla-Xa-TFPI (Fig. 3). TFPI is a Kunitz-type protease inhibitor with $\mathrm{K} 1, \mathrm{~K} 2$, and $\mathrm{K} 3$ domain, but the $\mathrm{K} 3$ domain is masked in lipoprotein-associated TFPI ${ }^{117}$. Therefore, the anticoagulant activity of lipoprotein-associated TFPI is likely to be lower than that of free TFPI ${ }^{118}$. It is estimated that about $50-60 \%$ of total circulating TFPI is bound to lipoproteins 119, whereas free TFPI represents only about $20 \%$ of total circulating TFPI. A third pool of TFPI is confined to platelets, which contain approximately $10 \%$ of the total TFPI in blood and release their TFPI after stimulation with thrombin ${ }^{120}$. TFPI in plasma has been shown to be heterogenous with respect to size. Only a small fraction circulates as full-length molecules whereas the majority 
consists of variably carboxy-terminal truncated forms ${ }^{121}$. The major endogenous source of TFPI, however, does not circulate but is thought to be bound to the vascular endothelium and is releasable after heparin infusion, whereupon plasma TFPI levels rise several fold ${ }^{122,123}$.

Plasma from healthy donors contains about $50-100 \mathrm{ng} / \mathrm{mL}$ TFPI ${ }^{124}$. Poor correlations have been reported between results obtained using different assays for TFPI measurement. These have included discrepancies between functional and antigenic assays ${ }^{125-127}$, as well as variable results using clotting and amidolytic assays ${ }^{128,129}$. It is likely that the different forms of TFPI present in plasma may be detected in varying degrees in current TFPI assays.

Information on the plasma half-life of TFPI is only available from pharmacokinetic animal studies with recombinant TFPI (rTFPl). After an intravenous bolus injection, rTFPI is rapidly cleared from the circulation with a plasma half-life of approximately 2 minutes in rabbits ${ }^{434}$ and less than 1 minute in rats ${ }^{135}$. As a result, high doses of recombinant TFPI are required to achieve therapeutic efficacy in clinical studies. The rapid clearance of rTFPI from the circulation is largely dependent on the binding of rTFPI to the endothelium via heparan sulfate proteoglycans, and to a lesser degree to its hepatic removal via the endocytic receptor LDL-receptor-related protein (LRP) 135,136 .

Despite extensive study of TFPI biochemistry and physiology during the last decade, little is known about the in vivo contribution of TFPI to the regulation of TF-dependent coagulation in ACS patients. In healthy vessels, TFPI protein and mRNA are present in luminal and microvascular endothelial cells and in smooth muscle cells ${ }^{137}$, whereas in atherosclerotic vessels, TFPI protein and mRNA frequently colocalize with TF within the plaque ${ }^{68,138}$. Several studies found that plasma TFPI levels are increased in the acute phase of UAP (Table 3). Gerotziafas et al. ${ }^{133}$ reported normal levels of free TFPI in patients with UAP on admission. Falciani et al. ${ }^{97}$ found elevated total TFPI levels in both AMI and UAP and effort angina compared with control subjects, and the TFPI antigen levels between these groups were not significantly different.

Taken together, TFPI levels in plasma seem to be increased in the acute phase of patients with ACS. Since the ability of TFPI to inhibit clotting in vivo is likely to be due to the free form of this inhibitor, measurement of this form of TFPI in a plasma sample would be of most significance. Furthermore, since functional assays may more likely reflect the in vivo anticoagulant action of TFPI, measurement of free TFPI by using functional assays would be preferable. However, this form of inhibitor is only a minor component of total TFPI, and current assays do not allow accurate quantitation of free TFPI. 


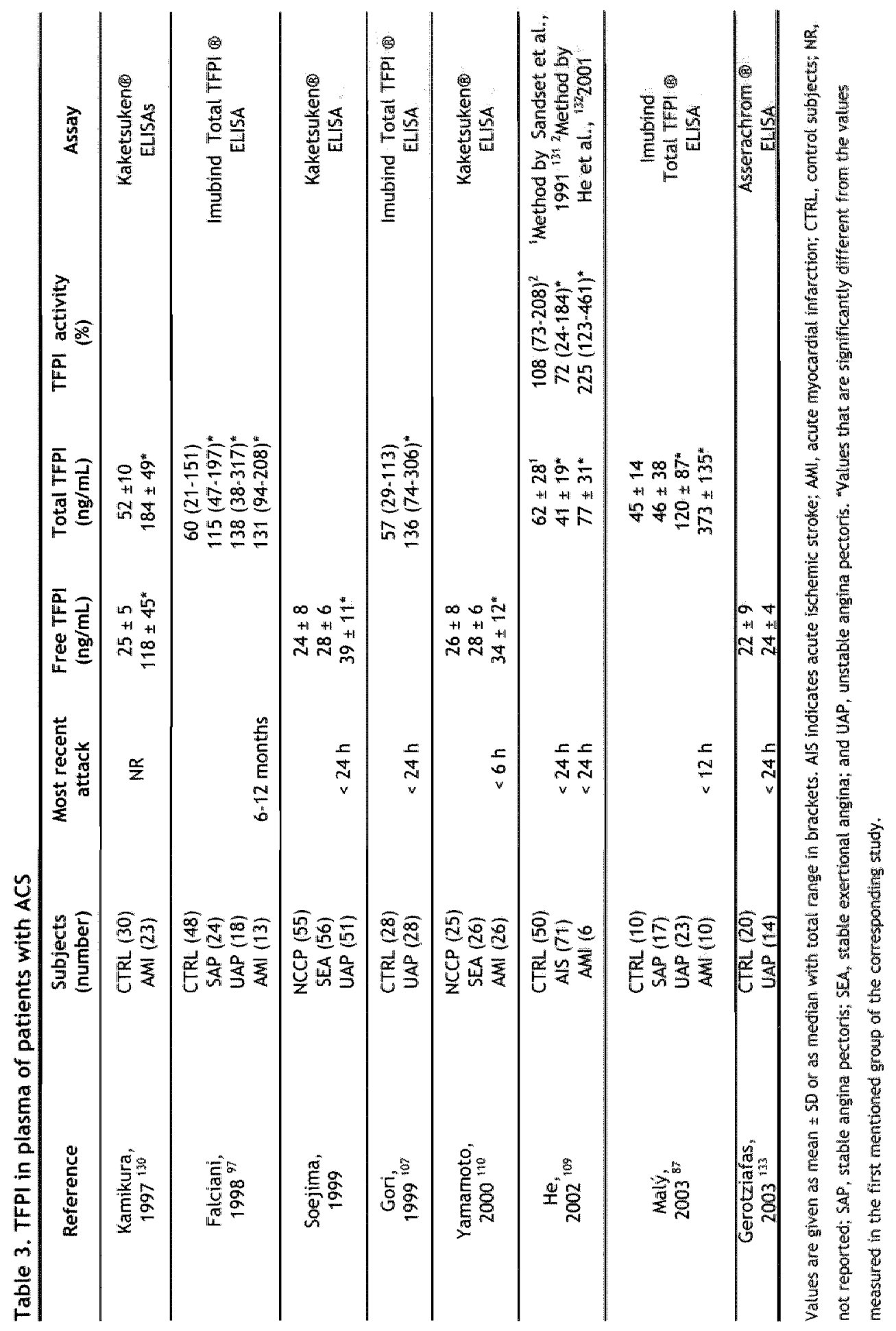




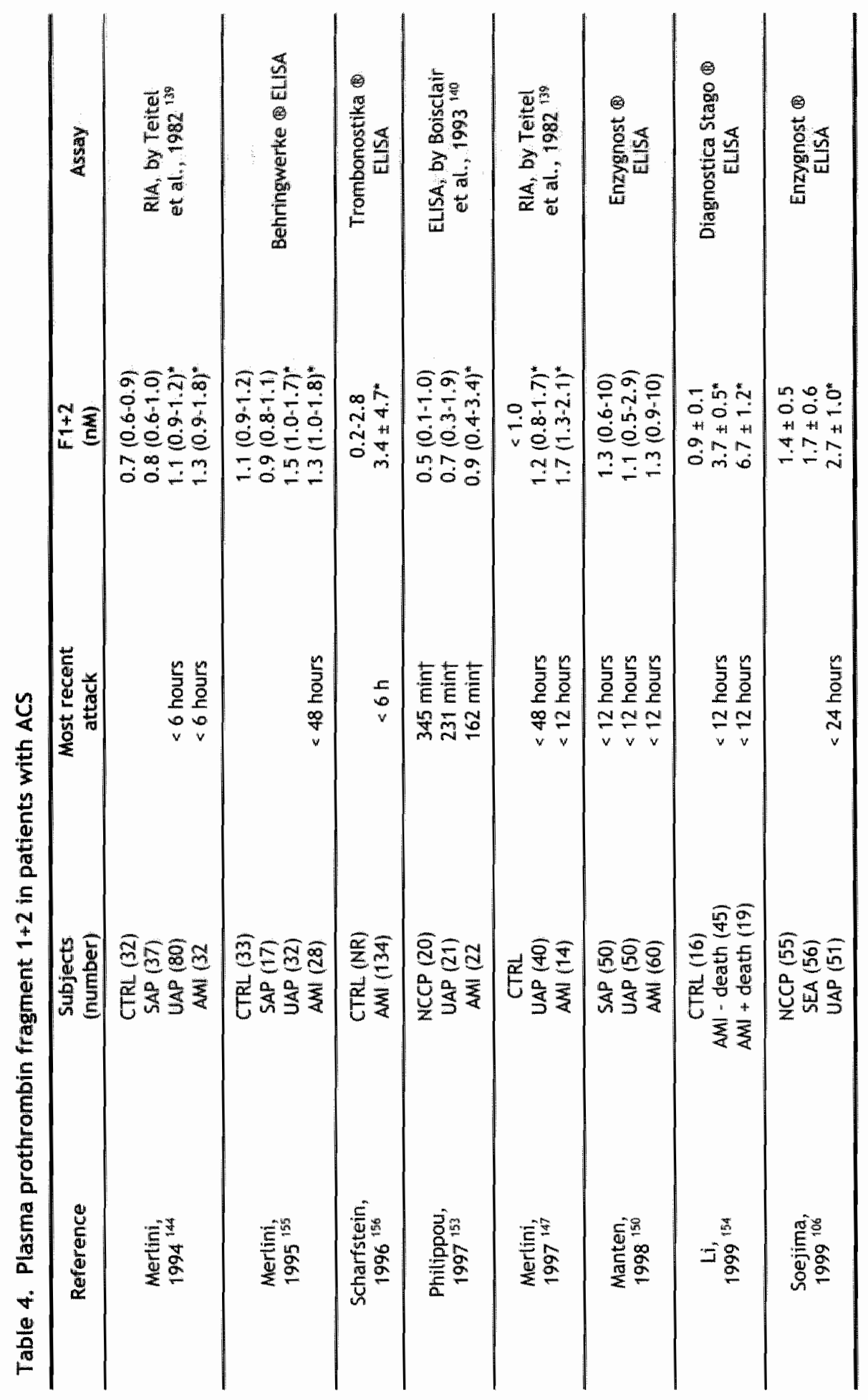




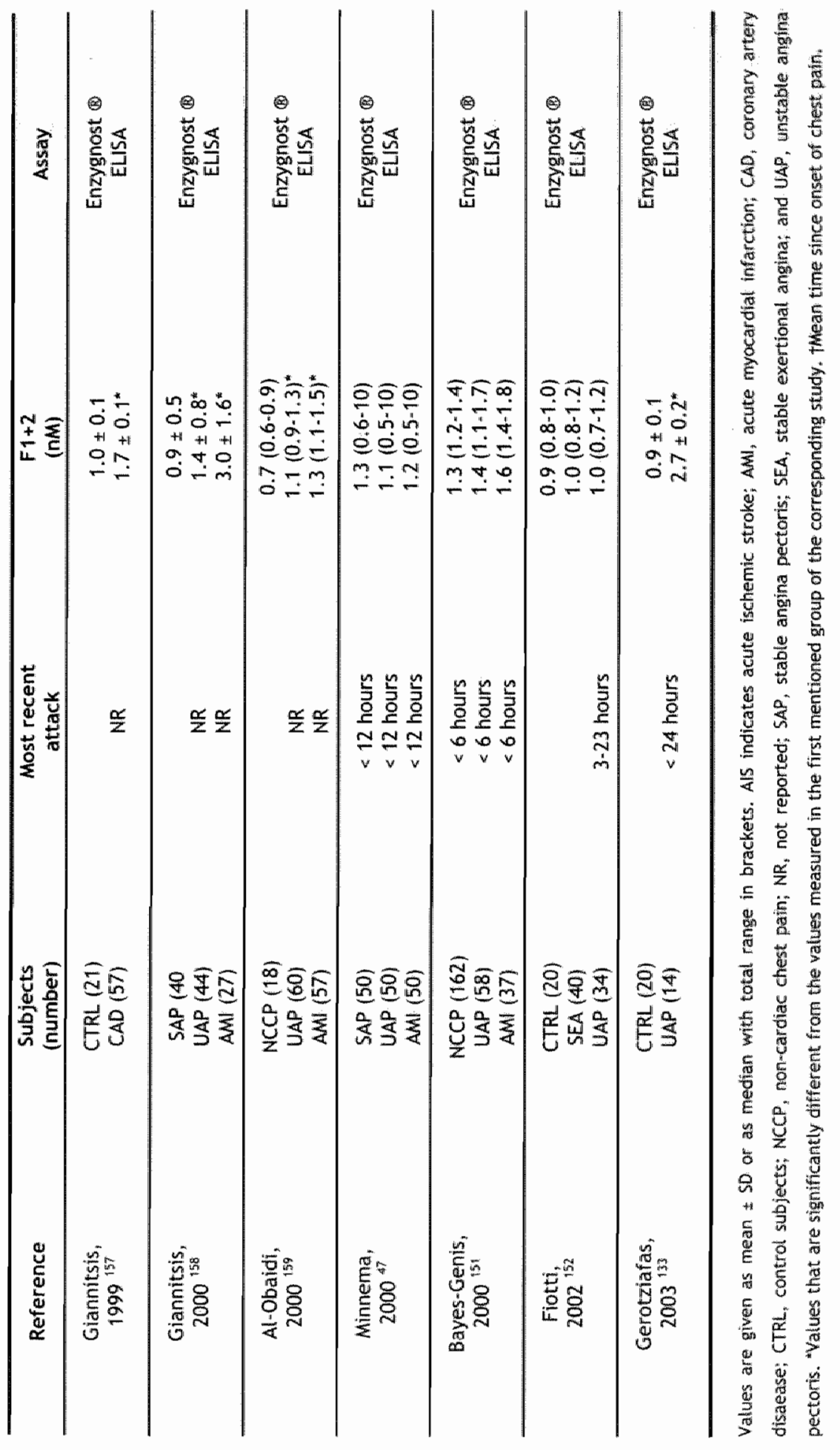




\section{Prothrombin fragment $1+2$}

Prothrombin fragment $1+2(F 1+2)$, is a $31 \mathrm{kD}$ polypeptide that is released from the amino terminal end of prothrombin during its conversion to thrombin (Fig. 4). Therefore, prothrombin fragment $1+2$ has been used as a sensitive marker of thrombin generation.

Assay methods available for its measurement include a radioimmunoassay 139 and several ELISAs ${ }^{140,141}$ have been developed to measure F1+2 levels in plasma, but interpretation of the results have been hampered by the dissimilarity of the assays with regard to anticoagulants and antibodies used 142. In initial studies, based on a radioimmunoassay, the normal range has been reported to be between 1.5 and $2.0 \mathrm{nM}$; with subsequent commercial assays, however, lower values for $F 1+2$ have been reported ${ }^{142}$. These differences may be attributed to the anticoagulant used for sample collection 143 , and the use of an antibody population that gives uniformly lower values 144. Increases in concentrations of F1+2 caused by ex vivo thrombin formation do not appear to occur frequently; nonetheless, increases may occur with poor blood sampling technique ${ }^{145}$. The half-life for prothrombin fragment $1+2$ in plasma has been reported to be approximately 90 minutes ${ }^{146}$.

Many studies have reported higher levels of $F 1+2$ in the acute phase of patients with ACS than in control subjects (Table 4), and increased plasma levels of $\mathrm{F} 1+2$ can be found months after $\mathrm{ACS}{ }^{97,144,147-149}$. Apparently, none of these studies reported differences between AMI and UAP patients. Also, quite a few studies have found normal levels in plasma F1+2 in AMI ${ }^{47,150-152}$ and UAP 47, 150-153.

The study by Li et al. ${ }^{154}$ showed that higher baseline levels of F1+2 in AMI patients were associated with an increased risk at sudden cardiac death during an average $27 \pm 17$ month follow-up period. Remarkably, plasma levels of $F 1+2$ in AMI patients in their study were exceptionally elevated, whereas the level in control subjects was similar to those measured with other assays. Merlini et al. ${ }^{144}$ studied plasma $\mathrm{F} 1+2$ and FPA levels in patients with ACS during the acute phase and after 6 months. They observed that both F1+2 and FPA were elevated on admission, suggesting ongoing thrombosis. After 6 months, in patients with an uneventful clinical course, the plasma levels of FPA had returned to within normal limits after 6 months, whereas those of $\mathrm{F} 1+2$ remained high. These results suggest that, although increased thrombin production persists after an acute ischemic episode, this is either insufficient or incapable of initiating fibrin formation and deposition. This condition indicates increased hemostatic system activity and has been considered typical of a "hypercoagulable state'.

To study the presence of a hypercoagulable state on long-term outcome, Ardissino et al. ${ }^{148}$ measured F1+2 levels during the acute phase of ACS and after 1,6 , and 12 months, and their relation to outcome was assessed during a 
median 29-month follow-up period. The primary end point of cardiac death or myocardial (re-)infarction occurred in 61 of 319 patients (19\%). Surprisingly, they observed a $\mathrm{U}$-shaped relationship between $\mathrm{FI}+2$ levels and the risk of developing the primary end point; intermediate levels $(1.5-1.9 \mathrm{nM})$ were associated with the lowest risk, whereas both higher $(>1.9 \mathrm{nM})$ and lower ( $<$ $1.5 \mathrm{nM}$ ) values were associated with an increased risk of an unfavorable outcome. The authors hypothesized that the protein $C$ pathway functions most efficiently in cases with intermediate levels of thrombin generation.

In conclusion, although many studies have shown elevated plasma $\mathrm{F} 1+2$ levels in the acute phase of ACS, increases are modest. Even more so, quite a few studies have reported normal levels in these patients. This may indicate that thrombin generation in these patients is low. Due to the 1:1 molar relation between thrombin generation and F1+2 levels, increases in markers of thrombin activity may be more apparent in these patients. Nonetheless, recent studies suggest that $F 1+2$ may reflect a prethrombotic state in patients with ACS that is not detected by increases of markers of thrombin activity.

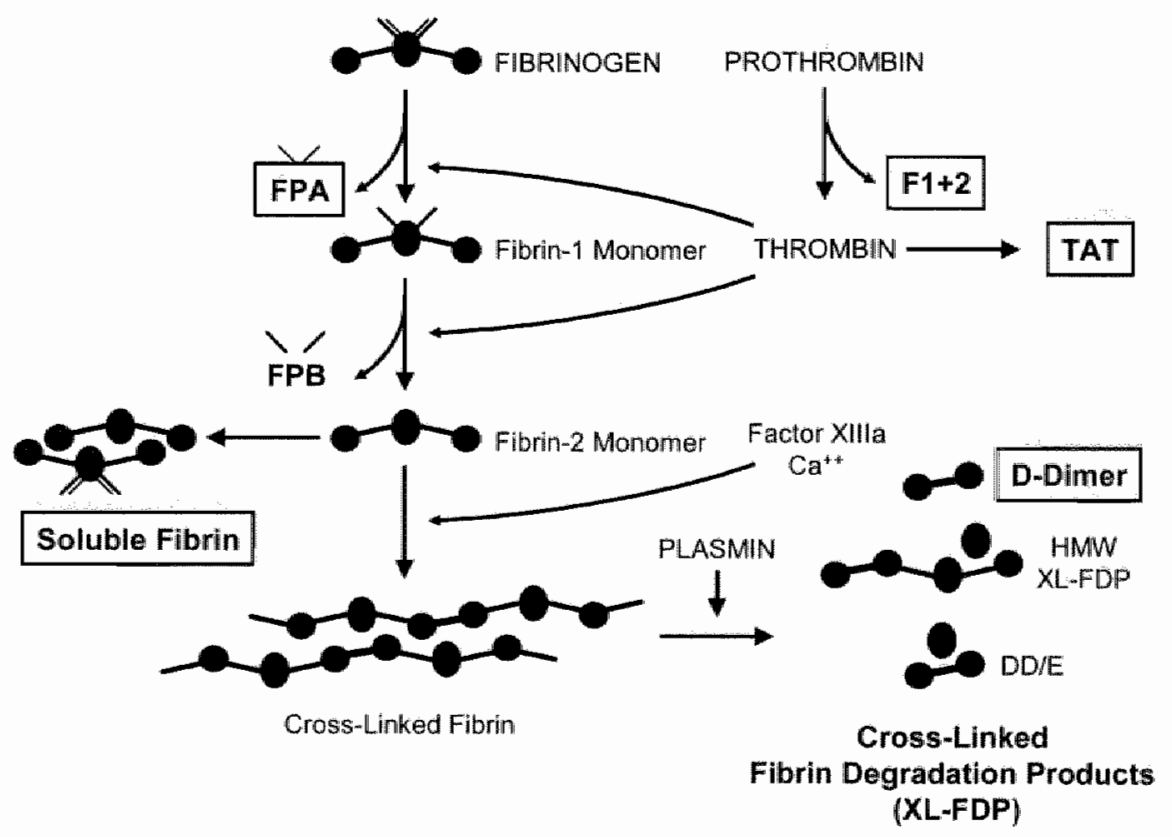

Figure 4. Sichematic representation of fibrin formation and degradation, focussed on the principal markers currently available, and discussed in detail in the text. DD/E $=D$-Dimer. fragment $E$ complexes, $F 1+2=$ prothrombin fragment $1+2, F P A=$ fibrinopeptide $A, F P B=$ fibrinopeptide $B, H$ HW $\mathrm{XL}-\mathrm{FDP}=$ high-molecular weight cross-linked fibrin degradation products, and TAT $=$ thrombin-antithrombin complex. 


\section{Thrombin-antithrombin complex}

Thrombin-antithrombin (TAT) complexes are formed when antithrombin binds and irreversibly inhibits the active site of thrombin (Fig. 4). Thus circulating TAT complexes can be detected after thrombosis is initiated and reflect thrombin formation ${ }^{2,141}$. The plasma half-life of TAT is not well defined because values ranging between $5 \mathrm{~min}$ and $12 \mathrm{~h}$ have been reported in animal models $2,160,167$, however, the most probable value for the half-life of TAT in humans, obtained from autologous TAT transfusion experiments, appears to be $15 \min ^{162,163}$.

Several assays have been developed for measurement of the TAT complex, based on either monoclonal antibodies to the complex or the use of two antibodies, one that binds thrombin and the other that binds antithrombin. The latter antibody is the basis of the most widely used commercially available assay ${ }^{141}$. The normal concentration of TAT varies from $1-3 \mu \mathrm{g} / \mathrm{L}$, depending on the assay used. Blood samples do not appear to be contaminated by ex vivo sample manipulation ${ }^{164}$.

In patients with ACS, most studies have shown that plasma TAT levels are increased in the majority of patients (Table 5), however, quite a few studies reported normal plasma levels in UAP 44,150,151,167 and AMI 150,151,165. Remarkably, the study by Granger et al. ${ }^{165}$, in which an ELISA by Diagnostica Stago was used, reported much higher values for TAT than the other studies (which used the Enzygnost ELISA).

In conclusion, TAT may be a useful parameter of increased thrombin generation in patients with ACS. Because of the reported short half-life of TAT, increases in TAT may reflect ongoing thrombosis in these patients, and provide evidence for the presence of a hypercoagulable state that is often found in these patients. On the other hand, its rapid clearance from plasma may limit the usefulness of TAT to detect a single acute episode of thrombin generation.

\section{Fibrinopeptide A}

The fibrinopeptides A (FPA) en B (FPB), of 16 and 14 peptides, respectively, are cleaved from the aminoterminus of fibrinogen by thrombin ${ }^{1}$ (Fig. 4). FPA is cleaved before FPB, and both peptides, once cleaved, may be further degraded by plasma carboxypeptidase activity. Three forms of FPA in plasma have been identified, one in which the aminoterminal alanine is cleaved (FPA-Y), and two forms in which the serine at position three is either phosphorylated (FPA-P) or not (FPA) ${ }^{168}$. Although FPB assays have also been developed, there is considerable less experience in the use of these assays to characterize thrombin activity.

Most of the antibodies that are used in the assays for measurement of FPA have been raised against the aminoterminus of the molecule that is also 
present on the FPA epitope on fibrinogen ${ }^{2}$. Accordingly, for FPA assays based on such assays plasma must be treated to remove fibrinogen. The method most widely used is incubating plasma with bentonite, which adsorbs fibrinogen and fibrin(ogen) degradation products but not FPA ${ }^{169}$. Antibodies against the carboxyterminus of FPA have also been described and have the advantage of not recognizing fibrinogen or fibrinogen degradation products containing FPA ${ }^{2}$. However, these antibodies do not recognize FPA that has been cleaved by plasma carboxypeptidases.

Table 5. Plasma TAT in patients with ACS

\begin{tabular}{|c|c|c|c|c|}
\hline Reference & $\begin{array}{l}\text { Subjects } \\
\text { (number) }\end{array}$ & $\begin{array}{l}\text { Most recent } \\
\text { attack }\end{array}$ & $\begin{array}{l}\text { TAT } \\
(\mu g / L)\end{array}$ & Assay \\
\hline $\begin{array}{c}\text { Scharfstein } \\
19966^{1156}\end{array}$ & $\begin{array}{l}\text { CTRL (NR) } \\
\text { AMI (185) }\end{array}$ & $<6 \mathrm{~h}$ & $\begin{array}{c}1.5 \times 3 \\
21.2 \pm 32.8^{*}\end{array}$ & $\begin{array}{l}\text { Enzygnost } \\
\text { ELISA }\end{array}$ \\
\hline $\begin{array}{c}\text { Kamikura, } \\
19977^{130}\end{array}$ & $\begin{array}{l}\text { CTRL (30) } \\
\text { AMI }(23)\end{array}$ & NR & $\begin{array}{c}1.7 \pm 0.5 \\
12.4 \pm 4.3^{*}\end{array}$ & $\begin{array}{c}\text { Enzygnost (B) } \\
\text { ELISA }\end{array}$ \\
\hline $\begin{array}{l}\text { Falciani, } \\
1998^{97}\end{array}$ & $\begin{array}{l}\text { CTRL (48) } \\
\text { SAP }(24) \\
\text { UAP }(18) \\
\text { AMI }(13)\end{array}$ & 6-12 months & $\begin{array}{c}2.3(1.4-4.2) \\
4.5(2.0-21.0)^{*} \\
6.3(3.2-15.4)^{*} \\
4.4(1.7-8.8)^{*}\end{array}$ & $\begin{array}{l}\text { Enzygnost } \\
\text { ELISA }\end{array}$ \\
\hline $\begin{array}{c}\text { Granger, } \\
1998^{165}\end{array}$ & $\begin{array}{c}\text { CTRL }(24) \\
\text { AML-Death/AM\| (202) } \\
\text { AMI+Death/AMI (24) }\end{array}$ & $\begin{array}{l}<6 \mathrm{~h} \\
<6 \mathrm{~h}\end{array}$ & $\begin{array}{c}<20 \\
18.7(13.2-26) \\
17.8(14.3-24.0)\end{array}$ & $\begin{array}{l}\text { Diagnostica } \\
\text { Stago } 10 \\
\text { ELISA }\end{array}$ \\
\hline $\begin{array}{l}\text { Manten, } \\
1998^{150}\end{array}$ & $\begin{array}{l}\text { SAP }(50) \\
\operatorname{UAP}(50) \\
\text { AMI }(60)\end{array}$ & $\begin{array}{l}<12 h \\
<12 h \\
<12 h\end{array}$ & $\begin{array}{c}4.8(2.3-60) \\
4.7(1.8-59.9) \\
6.6(19-60)\end{array}$ & $\begin{array}{c}\text { Enzygnost } \\
\text { ELISA }\end{array}$ \\
\hline $\begin{array}{l}\text { Hoffmeister, } \\
1999^{44}\end{array}$ & $\begin{array}{l}\text { CTRL (NR) } \\
\text { UAP }(31)\end{array}$ & NR & $\begin{array}{l}4.0 \pm 0.5 \\
7.6 \pm 1.9\end{array}$ & $\begin{array}{c}\text { Enzygnost } 1 \text { (B) } \\
\text { ELISA }\end{array}$ \\
\hline $\begin{array}{l}\text { Li, } \\
1999^{154}\end{array}$ & $\begin{array}{c}\text { CTRL (16) } \\
\text { AMI - death (45) } \\
\text { AMI + death (19) }\end{array}$ & $\begin{array}{l}<12 h \\
<12 h\end{array}$ & $\begin{array}{l}1.5 \pm 0.3 \\
11.2 \pm 2.6^{*} \\
27.3 \pm 5.7^{*}\end{array}$ & $\begin{array}{c}\text { Enzygnost } \\
\text { ELISA }\end{array}$ \\
\hline $\begin{array}{c}\text { Giannitsis, } \\
1999157\end{array}$ & $\begin{array}{l}\text { CTRL (21) } \\
\text { CAD (57) }\end{array}$ & $\mathrm{NR}$ & $\begin{array}{c}3.0 \pm 0.3 \\
15.6 \pm 2.7^{*}\end{array}$ & $\begin{array}{c}\text { Enzygnost } \\
\text { ELISA }\end{array}$ \\
\hline $\begin{array}{l}\text { Watanabe, } \\
2000^{165}\end{array}$ & $\begin{array}{l}\text { CTRL (25) } \\
\text { AMI }(25)\end{array}$ & $\mathbb{N R}$ & $\begin{array}{c}1.7 \pm 0.4 \\
12.7 \pm 4.7^{\star}\end{array}$ & $\begin{array}{c}\text { Enzygnost } \\
\text { ELLISA }\end{array}$ \\
\hline $\begin{array}{c}\text { Bayes-Genis, } \\
2000\end{array}$ & $\begin{array}{l}\text { NCCP }(162) \\
\text { UAP }(58) \\
\text { AMI }(37)\end{array}$ & $\begin{array}{l}<6 h \\
<6 h \\
<6 h\end{array}$ & $\begin{array}{c}5.2(4.7-5.9) \\
5.7(4.5-7.1) \\
8.4(6.9-10.2)\end{array}$ & $\begin{array}{l}\text { Enzygnost } \\
\text { ELIISA }\end{array}$ \\
\hline
\end{tabular}

Values are given as mean \pm 5D or as median with total range in brackets. All indicates acute ischemic stroke; AMI, acute myocardial infarction; CTRL, control subjects; NR, mot reported; SAP, stable angina pectoris; SEA, stable exertional angina; and UAP, unstable angina pectoris. Walues that are significantly different from the walues measured in the first mentioned group of the corresponding study. Talues that are significantly different from UAP. 
Using their assay, Nossel et al. ' originally reported plasma concentrations of FPA in healthy subjects between 0.1 and $0.3 \mathrm{nM}$ (which corresponds to 0.2 $0.5 \mu \mathrm{g} / \mathrm{L}$ ). However, significant differences in the concentrations of FPA have been reported in clinical studies in similar patient populations. These have been attributed to inadequate sample acquisition and processing, crossreactivity of fibrinogen degradation products containing FPA, and differences in antibody specificity.

In patients with ACS, most studies have shown that plasma FPA levels are increased in the majority of patients; only a few studies found normal plasma FPA levels in UAP ${ }^{147,167}$ and AMI ${ }^{147}$ (Table 6). Furthermore, although the studies by Manten et al. ${ }^{150}$ and Minnema et al. ${ }^{47}$ reported significantly higher plasma FPA levels in AMI, plasma levels of FPA are generally similar in UAP and AMI. It is important to note that since the half-life of FPA in plasma is rather short ( $3-5$ minutes $\left.{ }^{1,170}\right)$, increased concentrations suggest ongoing thrombin activity.

FPA is eliminated from plasma by renal clearance but, due to proteolytic degradation by circulating peptidases, only $30 \%$ of the filtered material consists of intact molecules. Most of the filtered FPA is catabolized by renal tubular peptidases, but $0.2-0.5 \%$ is excreted in urine ${ }^{170}$. To avoid potential difficulties with blood sampling that may result in ex vivo thrombin activity and artefactual increases in FPA, the amount of FPA excreted in 24-hour urine, where it is relatively stable ${ }^{170,174}$, has been proposed as an index of cumulative thrombin action on fibrinogen. Assays for measurement of both spot and 24-hour urine collections have been described, and a few studies reported increased $24 \mathrm{~h}$ urinary FPA levels in patients with UAP ${ }^{167,175,180}$ and AMI ${ }^{174,175,180}$. However, the urinary excretion of FPA in the setting of ACS is incompletely understood and these assays are not widely used.

In summary, plasma FPA levels are elevated in the acute phase of ACS. However, the requirement for meticulous blood sampling techniques have limited the use of FPA assays to the research setting. Since FPA is a very sensitive measure of thrombin activity, numerous controls and monitoring of sample acquisition are necessary. An alternative approach is the measurement of FPA in urine, but it is generally accepted that this method cannot be used to temporally define increased changes in concentration with precision of repetitive plasma sampling. Due to its short half-life in plasma, this marker indicates ongoing thrombin activity and is most likely not suitable to detect a single acute thrombotic event. 


\section{Fibrin monomer and soluble fibrin (thrombus precursor protein)}

Fibrin formation is a multistep process, initiated by thrombin (Fig. 4). First, thrombin will release fibrinopeptides $A$ from the amino-terminal ends of the two fibrinogen Ad-chains ${ }^{181,182}$ (Fibrin-1 Monomer). Simultaneously, but more slowly, fibrinopeptides $B$ are released from the amino-terminal $B B$. chains, producing desAABB-fibrin (Fibrin-2 Monomer). As a result of the release of fibrinopeptides $A$ and $B$, new amino-terminals are exposed on the fibrin $\alpha^{-}$and B-chains, which readily bind to complementary sites present in fibrinogen. The mechanisms responsible for the solubility of cross-linked species are not well understood. They may involve fibrin molecules at low concentration that are kept in solution by complexing to the relative excess of fibrinogen ${ }^{183-185}$. These complexes are referred to as soluble fibrin (SF), or as thrombus precursor protein (TPP). At a certain fibrin concentration, fibrinfibrin interactions will prevail and insoluble aggregates are formed, resulting in a macroscopic gel. Finally, activation of factor XIII to factor XIIla by thrombin leads to cross-linking of the fibrin subunits ${ }^{181,182,186,}$

Plasma levels of fibrin monomers (FM) and SF have not been studied extensively in the setting of ACS. A couple of studies reported increased plasma levels of FM in UAP ${ }^{187}$ and AMI ${ }^{166,187}$. Interestingly, two studies have reported a potential role for $F M$ in risk-stratification of patients with unstable angina; Giannitsis et al. ${ }^{158}$ detected increased plasma concentrations of FM in $46 \%$ of UAP patients and those were more frequently present among those with increased $\mathrm{TnT}$ concentrations $(73 \%$ vs. $27 \%$ in the group with negative $\mathrm{TnT}$ ). These findings confirmed an earlier study by Terres et al. ${ }^{188}$, who found that the proportion of UAP patients with at least one blood sample (within 48 $\mathrm{h}$ from onset of symptoms) showing an increased concentration of plasma fibrin monomer was also higher in the group with increased troponin $T(67 \%$ vs. $15 \%$ in the group with negative TnT). Accordingly, the observation that UAP patients with an elevated TnT level on admission have a prognosis as serious as patients with definite AMI ${ }^{189,190}$ may be explained by the presence of a hypercoagulable state in such patients.

To overcome previously mentioned limitations of FPA measurements, it has been suggested that measurement of soluble fibrin would be a good alternative. SF has a longer half-life in plasma, allowing a more convenient diagnostic window, and may have decreased susceptibility to sampling artefacts. However, SF species appear to have considerable molecular heterogenity, and there is no internationally accepted standard for SF. The assays that are most widely used for measurement of SF are based on ELISA methods. These tests typically incorporate capture monoclonal antibodies that are specific for neo-epitopes of soluble fibrin that are exposed on this molecule after cleavage of fibrinopeptides from fibrinogen. 


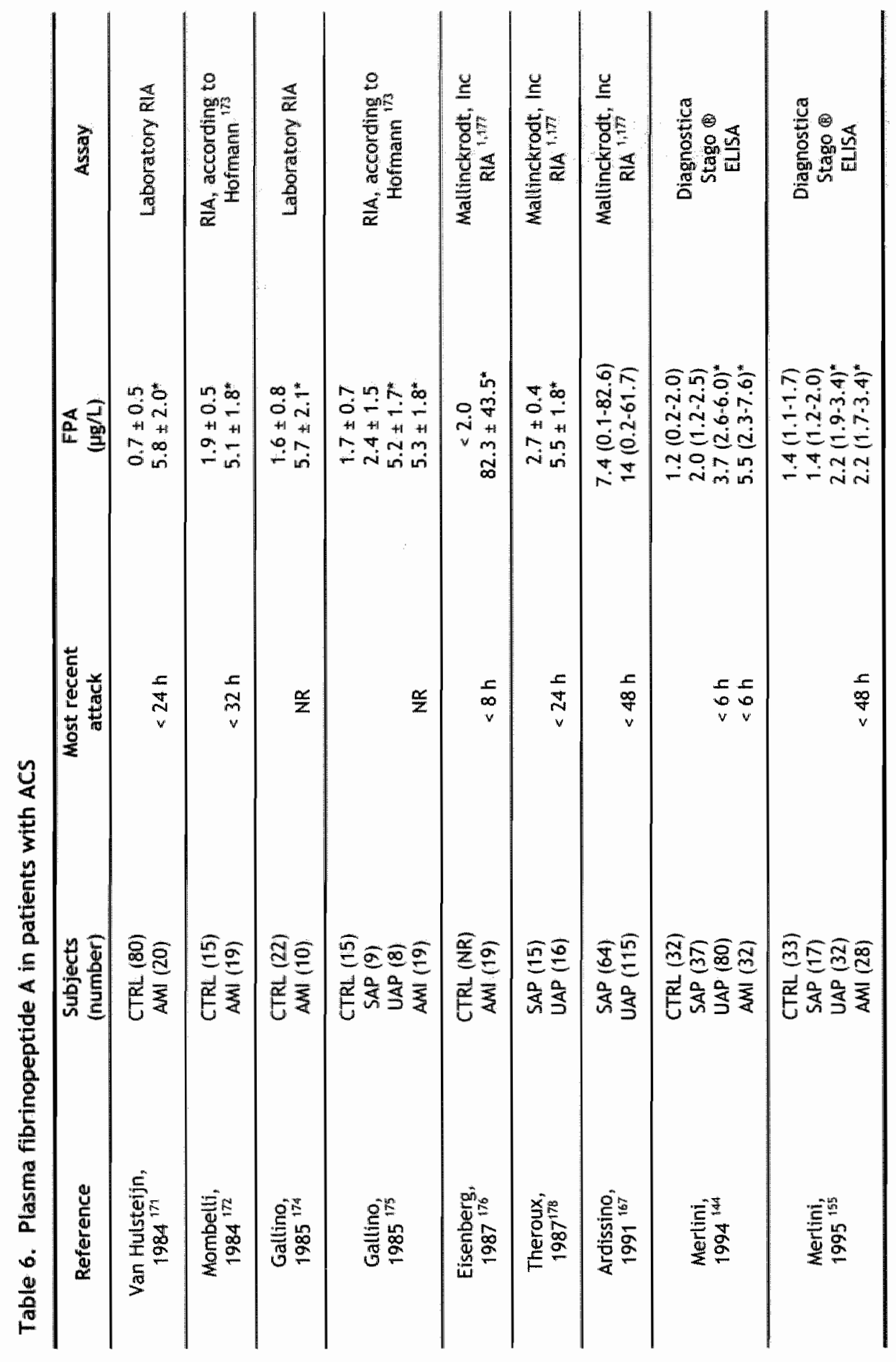




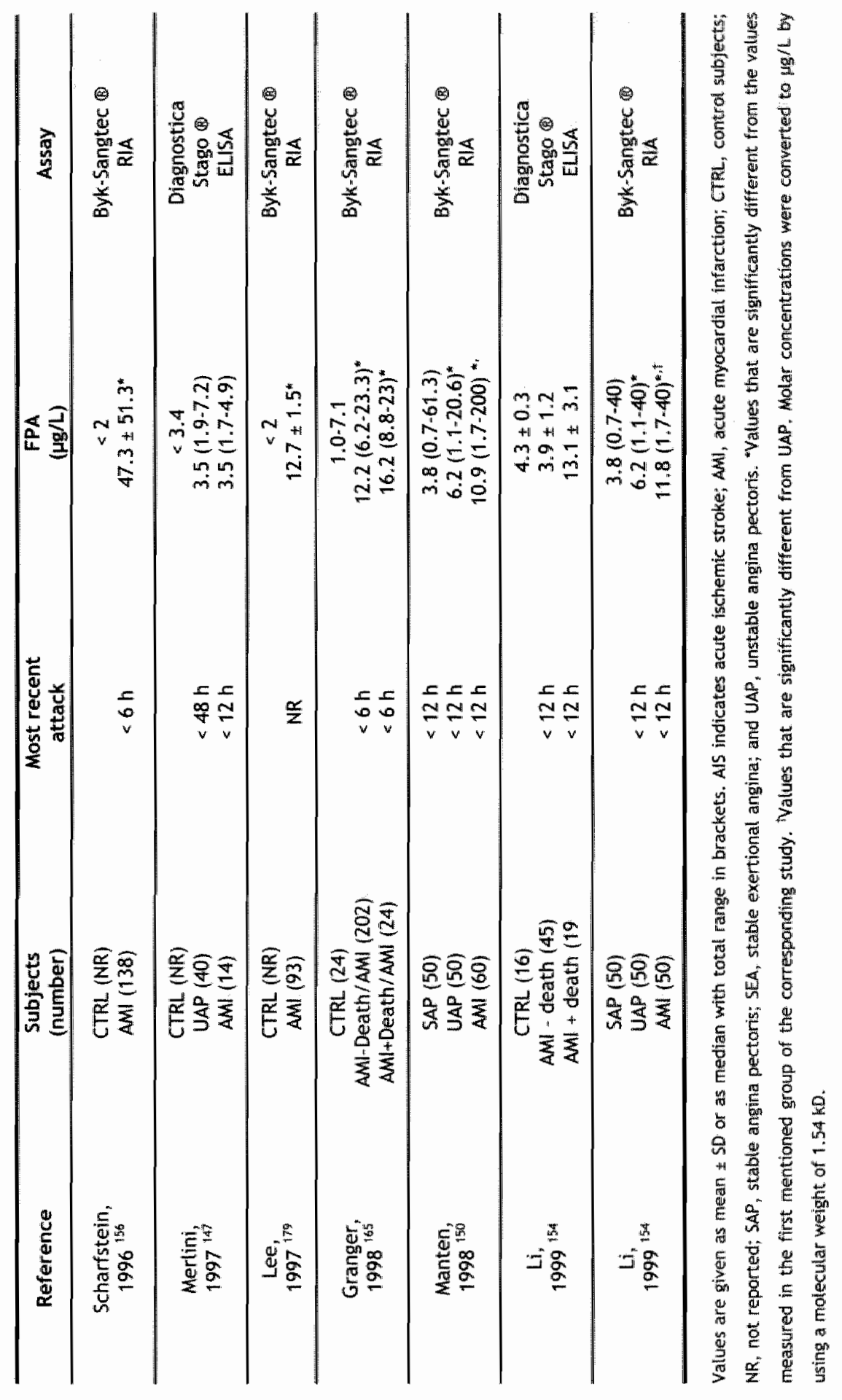


Carville et al. ${ }^{191}$ studied TpP levels in patients that presented with chest pain within $4 \mathrm{~h}$ from the onset of symptoms and found that in patients diagnosed with AMI, TpP levels were 4-20-fold those of healthy volunteers. In contrast, all but 3 UAP patients had TpP levels approximating that of the controls, as did the patients diagnosed with other chest pain. The 3 UAP patients that had increased TpP, all progressed to Ml within 48 hours. TpP levels seem to be increased especially in the early hours after $A M{ }^{191-193}$, and the study by Hermens et al. ${ }^{192}$ showed that TpP was able to differentiate AMI from UAP. Laurino et al. ${ }^{193}$ found increased TpP in $88 \%$ of AMl patients, in $63 \%$ of UAP patients, but also in $50 \%$ with angina and in $55 \%$ with non-cardiac chest pain. Even more so, one study ${ }^{152}$ reported similar TpP concentrations in UAP, SAE and healthy controls. Derhaschnig et al. ${ }^{194}$ studied whether a SF bedside test could help in early identification of ACS patients in the emergency department. They found that $76 \%$ of patients with unstable angina pectoris (UAP) had a positive SF bedside test, whereas only $30 \%$ of patients with nonST-segment-elevation myocardial infarction and $23 \%$ of patients with STelevation myocardial infarction tested positive. Three percent of controls and $11 \%$ of patients with pre-existing stable angina had a positive SF bedside test, yielding an overall specificity of $92 \%$ and a sensitivity of $35 \%$ for the detection of ACS.

Taken together, elevations of SF have been reported in patients with ACS, but current tests lack sufficient discriminating power and may cross-react substantially with fibrin(ogen) degradation products.

\section{Plasminogen activator inhibitor}

Intravascular fibrinolytic activity is regulated by a balance between plasminogen activators, such as t-PA, and inhibitors, such as PAI-1 and $a_{2}$ antiplasmin. The key event is the conversion of the inactive plasminogen into the proteolytically active plasmin, which degrades fibrin. Plasmin formation in the circulation is strongly dependent on PAl-1 levels. PAI-1 inhibits, by complex formation, t-PA which is released by the vascular endothelium.

PAI- 1 can be measured with assays that measure the residual activity after addition of a known amount of t-PA ${ }^{195}$. However, the levels measured with these methods may be inaccurate because of formation of t-PA/PAI- 1 complexes, and platelet activation with release of active PAl-1 during sample acquisition. Mass concentrations of PAI-1 can be measured by RIA or ELISA methods ${ }^{196}$. These assays are more sensitive than activity-based assays in the ability to detect PAl-1 in both free form or bound in the t-PA/PAl-1 complex.

Plasma PAl-1 antigen ${ }^{197}$ and activity ${ }^{44,46,105,198}$ levels have been shown to be elevated in the acute phase of UAP. Plasma PAI-1 antigen 130,199,200 and activity ${ }^{201}$ levels were also found to be elevated in the acute phase of AMI. Munkvad et al. ${ }^{201}$ found higher PAl-1 activity levels in AMI than in UAP, and 
increased PAI-1 levels may persist for prolonged periods of time after the acute phase of UAP ${ }^{46,197}$ and AMI ${ }^{202,203}$.

There is not yet a consensus on the prognostic value of this marker. PAl-1 activity was found to have a prognostic value in some studies ${ }^{202,204 \cdot 207}$, but not in others ${ }^{208-210}$. In ST-segment elevated AMI, the acute rise of PAI-1 antigen was a strong independent predictor of death at 30 days ${ }^{199}$. Juhan-Vague et al. ${ }^{211}$ followed 3043 patients with angina pectoris for 2 years, and reported that an increased incidence of events (AMI or sudden coronary death) was associated with higher baseline levels of PAl-1 activity and PAI-1 antigen.

To summarize, increased levels of PAI- 1 antigen and activity have been reported in patients with ACS. There are also data suggesting that measurement of PAl-1 is useful in identifying patients at high risk for future cardiac events, but their role in assessing prognosis in patients with ACS is still controversial.

\section{D-Dimer}

When fibrinogen and fibrin are exposed to the action of circulating plasmin, proteolytic digestion leads to the formation of degradation products (Fig. 4). The digestion of fibrinogen yields fragments $X, Y, D$ en $E$, which are collectively known as fibrinogen degradation products. On the other hand, digestion of fibrin yields distinct cleavage products such as the $X Y, D D$ and $D Y$ dimers. These products are specific indicators of the formation of fibrin and its digestion by plasmin, and are collectively known as fibrin degradation products.

Kruskal et al. ${ }^{187}$ and Francis et al. ${ }^{212}$ were probably the first to show the presence of cross-linked fibrin degradation products (XL-FDPs) in plasma from patients with ACS. Nowadays, the assays that are most commonly used for measurement of D-Dimer are latex agglutination assays based on a single monoclonal antibody, and sandwich ELISAs using two antibodies. The quantitative ELISAs may be more accurate than semi-quantitative latex tests 213. Because of the complex nature of the molecular structure of XL-FDPs, accurate quantification of plasma concentrations of D-Dimer is critically dependent on the specificity of the antibodies that are used in these assays. Different antibodies are used in assay kits from different manufacturers, which do not show high correlations and which give different reference ranges 213-215. Generally, plasma D-Dimer levels at concentrations $<500 \mu \mathrm{g} / \mathrm{L}$ are present in healthy subjects ${ }^{216}$. There is no consensus on the half-life of $D$ Dimer in plasma; values have been reported ranging from $3-48$ hours ${ }^{179,187,217}$. Clearance of D-Dimer has been suggested to occur via the reticulo-endothelial system, although this has not been studied in humans ${ }^{217}$.

Table 7 summarizes studies that have reported on D-Dimer levels in patients with ACS. Whereas most studies have shown higher D-Dimer levels in 


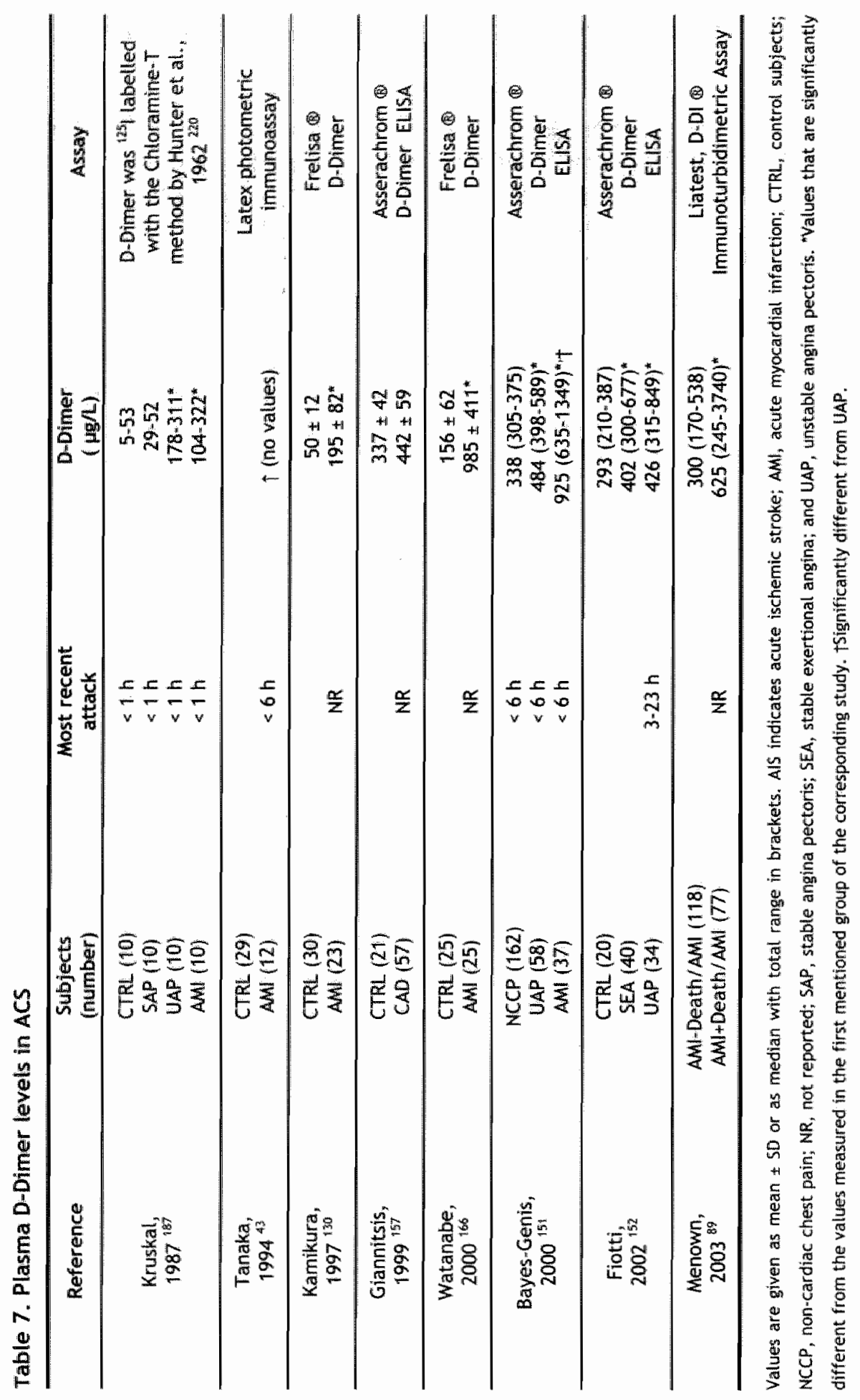


these patients than in control subjects, it is not clear whether D-Dimer levels between AMI and UAP patients are different; whereas Bayes-Genis et al. ${ }^{151}$ did find different levels between these groups, others ${ }^{187}$ did not find such differences.

In UAP patients, D-Dimer levels on admission were found to be significantly increased, especially in those patients who developed adverse events during hospitalization ${ }^{152}$. Increased D-Dimer levels may be found in plasma months after $A M I^{149,218,219}$. A study comprising 1,045 post-AMl patients showed that high levels of D-Dimer 2 months after AMI were associated with recurrent coronary events during an average 26 month follow-up period ${ }^{219}$.

Menown et al. ${ }^{89}$ studied 391 patients admitted to the hospital with acute ischemic chest pain. Patients with normal levels of CK-MB and cTnl (195 of 391) on admission were at lower risk than patients with elevated levels of CKMB or CTnl, but still had an important incidence of events (in 77 of 195 patients). Elevated D-Dimer levels ( $>580 \mu \mathrm{g} / \mathrm{L}$ ) were predictive of death or AMI within the 1 year follow-up period for these patients. Therefore, normal CTnl levels after acute chest pain is not a good criterion for selecting patients who are at low risk for developing future cardiac events. Concurrent assessment of D-Dimer may improve risk stratification.

In clinical settings, the use of D-Dimer has been proven useful in patients with overt thrombosis, such as pulmonary thromboembolism (PE) and deep venous thrombosis (DVT) ${ }^{215,217}$. In these thrombotic disorders, sensitivities are generally high $(>90 \%) \quad 215,217,221$, whereas specificities are rather low $(<50 \%)$ $215,217,222$. Therefore, D-Dimer is used to rule out PE or DVT when its concentration is below a given cut-off. Although some studies have shown elevations in D-Dimer in admission samples of patients with ACS, clinical data assessing the value of D-Dimer in patients with acute chest pain are rather limited.

\section{Influence of physiological factors, medications and organ dysfunction}

Bauer ${ }^{163}$ has reviewed a number of variables that can cause overlap of assay results between people with a pathological condition or altered physiological status and normals. While values further from the mean of the normal distribution are more likely to reflect pathology, and appropriate interpretation requires an appreciation of the factors that can influence measurement results.

The normal aging process alters coagulation activation in a predictable fashion ${ }^{223,224}$. With advancing age from $45-70$ years, increasing numbers of patients who are otherwise normal exhibit elevated levels of F1+2. These increased concentrations are due to increased production rather than decreased clearance of the marker ${ }^{223}$. The same has been shown for factor $\mid X$ and $X$ peptides 225 . Significant, but somewhat less striking, positive 
correlations have been observed between increasing age and the levels of FPA and protein $C$ activation peptide ${ }^{223}$. Exercise in the form of long-distance running leads to increased TAT complex levels without elevations of FPA ${ }^{226}$. Cigarette smoking has been associated with elevations of activation peptides of factor $\mathrm{IX}$ and $\mathrm{X}$, and $\mathrm{F} 1+2^{227}$.

Certain medications are known to have an effect on blood coagulation. Daily administration of oestrogen to menopausal women for 3 months increased the levels of $\mathrm{F} 1+2$ in a dose-dependent manner. FPA also increased and levels of protein $S$ and antithrombin were decreased as compared to placebo treatment ${ }^{228}$. Treatment of coronary heart disease patients with gemfibrozil, a drug used to lower serum cholesterol and triglyceride concentrations, reduced $\mathrm{F} 1+2$ levels by about $25 \%{ }^{229}$.

In healthy individuals, post-prandial elevations in the levels of factor V/la as well as factor $\mathrm{IX}$ activation peptide have been demonstrated, but no changes were observed in the levels of factor Xlla or indices of thrombin generation 230.232. The roles of factor XII, XI and factor IX in factor VII activation were evaluated by investigating patients with isolated deficiencies of these factors after a fatty meal 230,231 . It was concluded that factor IX plays a critical role in the events linking post-prandial lipemia to factor VII activation, and that factor XII was not involved in the activation of factor VII by lipolysis of triglyceride-rich lipoproteins.

Dysfunction in normal physiological clearance mechanisms can potentially result in substantial elevations in the levels of activation peptides. For $\mathrm{F} 1+2$, this has been shown in patients with chronic renal failure on dialysis ${ }^{140,233}$.

Therefore, one must be cautious in interpreting an elevated level of a marker as evidence of heightened coagulation or fibrinolytic activity in disorders associated with renal (e.g., thrombotic thrombocytopenic purpura, systemic lupus erythematosus, nephrotic syndrome, renal transplant rejection) or hepatic dysfunction.

\section{$>\mid$ CONCLUSIONS}

Plasma levels of markers of coagulation activation have been studied extensively in patients with ACS and have been used to study the pathophysiology of ACS, to investigate and attempt to monitor the effects of anticoagulant or antithrombotic drugs, and to assess prognosis. Surprisingly, although there is compelling evidence for a major role of thrombosis in the development of ACS and their complications, few studies have reported on the sensitivity and specificity of hemostatic markers to detect ACS in a clinical setting. 


\section{Sensitivity for the detection of coronary thrombosis}

Most patients that were enrolled in the studies discussed in this review included ACS patients that presented several hours after onset of chest pain. increased levels of markers with relatively short half-lifes (e.g., FPA, TAT, etc.) reflect ongoing thrombosis at the time of bloodsampling. Therefore, their role in diagnosing patients with chest pain seems limited, but they may be useful in identifying patients who are at an increased risk for the development of future cardiac events. In contrast, increased levels of markers with relatively longer half-lifes (e.g., F1+2, D-Dimer) may be more successfull in establishing ACS diagnosis.

However, the sensitivity of these markers is highly variable, depending on the time of blood sampling relative to the time course of the thrombotic event. Other factors that may reduce the sensitivity of activation markers of coagulation are: (a) a relatively small thrombus in a small sited coronary artery may not yield detectable elution of activation markers into the systemic circulation, particularly when the vessel is already occluded; (b) experience with fibrinolytic therapy suggests that only $-50 \%$ of occlusive thrombi may be considered fibrin-rich ${ }^{76,78}$.

\section{Specificity for the detection of coronary thrombosis}

Appropriate interpretation of measured marker levels requires an appreciation of potentially confounding factors. Markers of activated coagulation reflect the presence of thrombosis in any vascular bed, not necessarily in the coronary circulation. Aging, the use of certain drugs, and dysfunction in physiologic clearance mechanisms can result in substantial elevations in the levels of markers of coagulation activation. For some markers 'in vitro' artefacts during sampling are known. The cut-off level for each marker, to be used for the definition of elevations, is still largely unknown given the dissimilarities of the analytical methods used. Elevations may also occur in the absence of overt thrombosis, the so-called prethrombotic state.

In general, markers of coagulation activation are rapidly cleared from the circulation, and thus become less useful with longer periods after the acute event. In contrast, as explained previously, markers of myocardial necrosis are not detectable until a few hours after the acute event. Therefore, in order to establish an accurate diagnosis that is independent on the delay of the patient to the hospital, it seems useful to combine plasma markers of coagulation activation and myocardial necrosis. Surprisingly, only a few studies have reported on the sensitivity and specificity of hemostatic markers to detect ACS in a clinical setting (Table 8). 


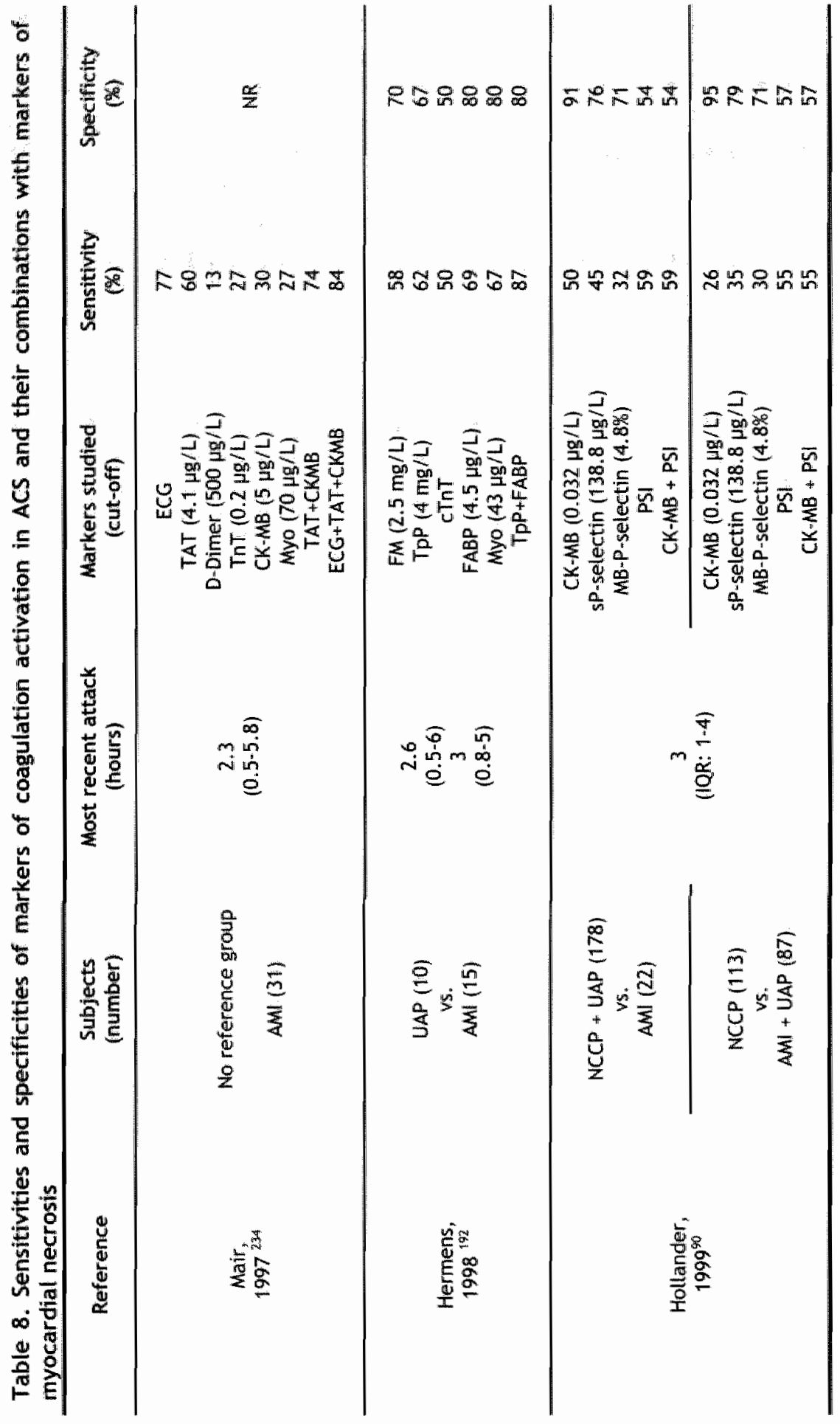




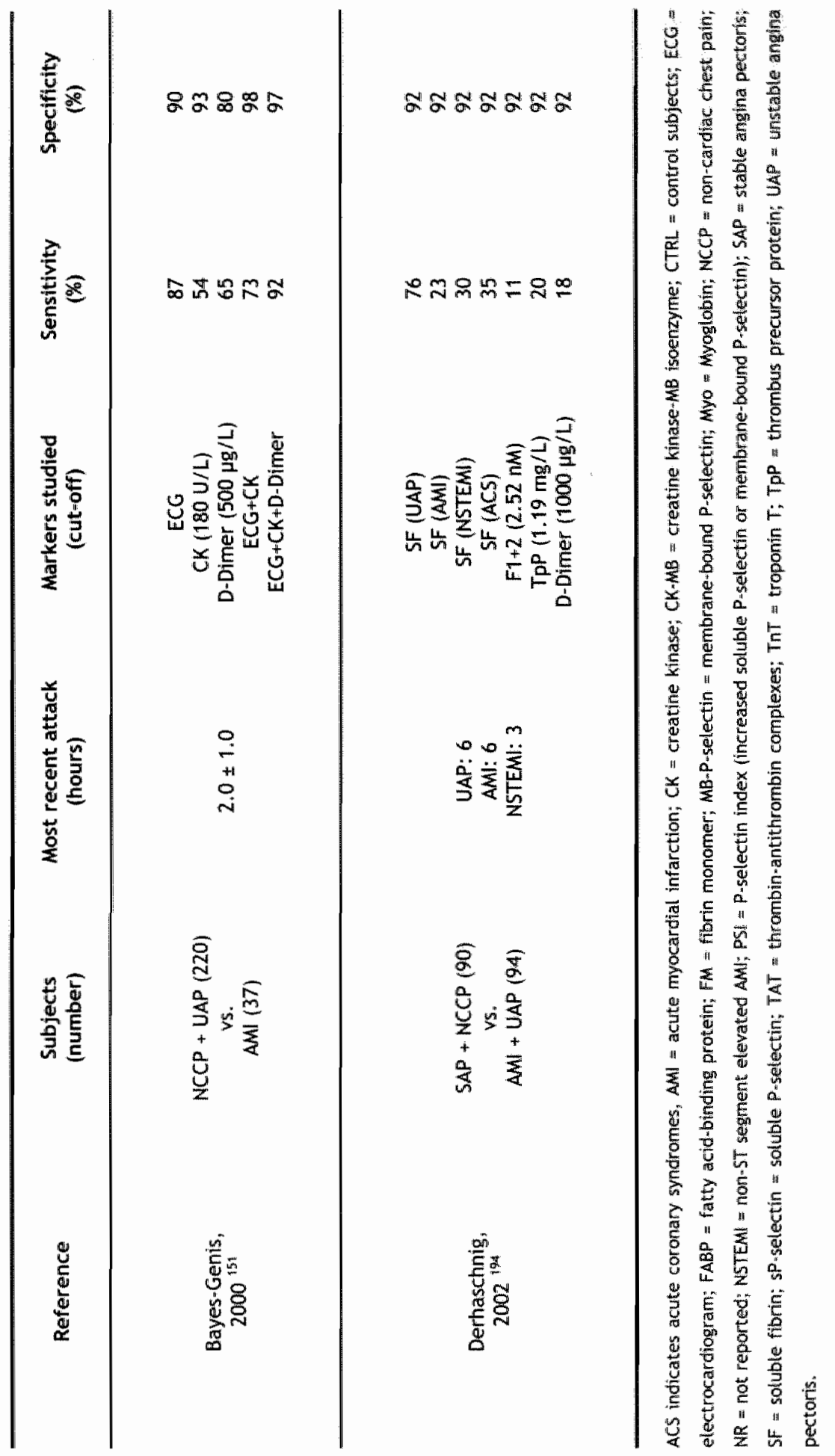


Mair et al. ${ }^{234}$ evaluated and compared the early sensitivities of TAT, Ddimer, myoglobin, CK-MB mass concentration, and TnT on admission to a coronary care unit (CCU). Of all hemostatic markers tested, TAT had the highest early sensitivity (60\%) on admission to the CCU. However, in this group of patients for which the median delay from chest pain onset to CCU admission was 2.3 hours, the ECG was still the most sensitive single method for early AMI diagnosis (77\%). By using the combination of ECG, CK-MB mass and TAT, $84 \%$ of all AMI patients could be identified on CCU admission.

Hermens et al. ${ }^{192}$ evaluated the combined use of markers of coagulation activation (fibrin monomer (FM) and thrombus precursor protein (TPP)) with markers of myocardial necrosis (Myo, FABP and TnT) in the early discrimination of AMI from UAP. A FABP level $>4.5 \mu \mathrm{g} / \mathrm{L}$ had a diagnostic sensitivity for AMI of $69 \%$ and a specificity of $80 \%$. The addition of TpP $>4$ $\mathrm{mg} / \mathrm{L}$ to the analysis resulted in an $18 \%$ increase of diagnostic sensitivity for AMl (from 69\% to 87\%) without losing specificity (80\%). Hollander et al. ${ }^{90}$ compared the properties of P-selectin to CK-MB for the detection of AMI or ACS upon arrival to the emergency department. As will be appreciated from Table 1, the use of soluble or membrane-bound P-selectin in the triaging of chest pain patients did not appear to have any advantages over the use of $\mathrm{CK}$ $M B$.

Bayes-Genis et al. ${ }^{151}$ evaluated the combined use of markers of myocardial necrosis and markers for activated coagulation in the early discrimination of AMI from non-AMI (UAP and non-cardiac chest pain). A positive ECG and first $C K$ reading $>180 \mathrm{U} / \mathrm{L}$ had a diagnostic sensitivity for $A M I$ of $73 \%$ and a specificity of $98 \%$. The addition of D-Dimer $>500 \mu \mathrm{g} / \mathrm{L}$ to the analysis resulted in a $19 \%$ increase of diagnostic sensitivity for AMI (from $73 \%$ to $92 \%$ ) without losing specificity (97\%). TAT complexes, F1+2, and activated factor VII provided no additional diagnostic information for patients with ACS in the emergency department.

Derhaschnig et al. ${ }^{19 / 4}$ studied whether a SF bedside test could help in early identification of patients with ACS in the emergency department. Whereas $76 \%$ (13 of 17) of patients with UAP had a positive SF bedside test, only 10 of 33 patients (30\%) with non-ST-segment-elevation myocardial infarction and 10 of 44 patients (23\%) with ST-elevation myocardial infarction tested positive. Three percent of controls ( 1 of 33) and 11\% of patients (6 of 57) with preexisting stable angina had a positive SF bedside test, which resulted in an overall specificity of $92 \%$ and a sensitivity of $35 \%$. The sensitivity of established coagulation markers to detect ACS was significantly less (11\% for prothrombin fragment $1+2,20 \%$ for thrombus precursor protein, and $18 \%$ for D-dimer). The SF bedside test presented the earliest objective indicator of impending myocardial damage in the majority (10 of 13) of ACS patients with a normal or non-diagnostic electrocardiogram (ECG). 
To summarize, from these studies it is not clear whether combining markers of coagulation activation and myocardial necrosis is valuable in the early diagnosis of ACS. The results are non-conclusive, and are difficult to compare because these studies differ in: (i) inclusion/exclusion criteria; (ii) definitions of AMI and UAP; (iii) reference groups; (iv) assays and (v) cut-off values, that were used.

\section{Tissue factor - a promising early marker of coagulation activation?}

A number of studies have reported increased plasma TF antigen levels in the acute phase in patients with unstable angina ${ }^{97,104-108}$ and myocardial infarction $96,109,110$. The role of plasma TF remains poorly understood due to the limited availability of assays that are capable of measuring plasma TF activity. The finding that only a few groups have reported data on plasma TF activity is probably due to the presence of many procoagulant and anticoagulant pathways involved in blood coagulation that complicate the direct measurement of TF activity in plasma. To date, no study has addressed the value of measurement of TF antigen and activity, in terms of sensitivities and specificities, in the acute phase of these syndromes. Therefore, the value of these markers in the early diagnosis of ACS, still needs to be elucidated in well-organized clinical trials considering large groups of patients. 


\section{$>$ REFERENCES}

1. Nossel HL, Yudelman I, Canfield RE, Butler VP, Jr. Spanondis $K$, Wilner GD, Qureshi GD. Measurement of fibrinopeptide $\mathrm{A}$ in human blood. $J \mathrm{Clin}$ invest. $1974 ; 54: 43-53$.

2. Nossel HL, Butler VP, Jr., Wilner GD, Canfield RE, Harfenist EJ. Specificity of antisera to human fibrinopeptide $A$ used in clinical fibrinopeptide $A$ assays. Thromb Haemost. 1976;35:101-9.

3. Selwyn AP. Prothrombotic and antithrombotic pathways in acute coronary synidromes. Am J Cardiol. 2003;91:3H-11H.

4. Nakamura T, Kambayashi J, Okuma M, Tandon NN. Activation of the GP IIb-Illa complex induced by platelet adhesion to collagen is mediated by both alpha2beta1 integrin and GP VI. J Biol Chem. 1999;274:11897-903.

5. Kroll MH, Hellums JD, Mclintire LV, Schafer Al, Moake VL. Platelets and shear stress. Blood. 1996;88:1525-41.

6. Frenette PS, Wagner DD. Adhesion molecules--Part II: Blood vessels and blood cells. N Engl J Med. 1996;335:43-5.

7. Pakala R, Willerson JT, Benedict CR. Effect of serotonin, thromboxane A2, and specific receptor antagonists on vascular smooth muscle cell proliferation. Circulation. 1997;96:2280-6.

8. Shebuski RJ, Kilgore $\mathrm{KS}$. Role of inflammatory mediators in thrombogenesis. I Pharmacol Exp Ther. 2002;300:729-35.

9. Loppnow $H_{3}$ Bill R, Hirt S, Schonbeck U, Herzberg $M$, Werdan $K$, Rietschel $\mathbb{E T}$,

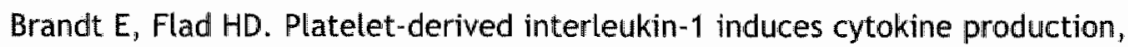
but not proliferation of human vascular smooth muscle cells. Blood. 1998;91:134-41.

10. Freedman JE, Frei B, Wellch GN, Loscalzo J. Glutathione peroxidase potentiates the inhibition of platelet function by S-nitrosothiols. J Clin Invest. $1995 ; 96: 394-400$.

11. Jahn B, Hansch GM. Oxygen radical generation in human platelets: dependence on 12-lipoxygenase activity and on the glutathione cycle. Int Arch Allergy Appl Immunol. 1990;93:73-9.

12. Marti F, Bertran $\mathbb{E}$, Llucia $M$, Villen $E$, Peiro $M$, Garcia J, Rueda F. Platelet factor 4 induces human natural killer cells to synthesize and release interleukin-8. J Leukoc Biol. 2002;72:590-7.

13. Harrison P, Cramer EM. Platelet alpha-granules. Blood Rev. 1993; 7:52-62.

14. Muller I, Klocke A, Alex M, Kotzsch M, Luther T, Morgenstern E, Zieseniss 5 , Zahler 5, Preissner $K$, Engelmann B. Intravascular tissue factor initiates coagulation via circulating microvesicles and platelets. Faseb J. 2003;17:4768.

15. Zillmann A, Luther T, Muller I, Kotzsch $M$, Spannagl $M$, Kauke T, Oelschlagel U, Zahler $S$, Engelmann B. Platelet-associated tissue factor contributes to the 
collagen-triggered activation of blood coagulation. Biochem Biophys Res Commun. 2001:281:603-9.

16. Rauch $U$, Bonderman D, Bohrmann B, Badimon $J J$; Himber $J$, Riederer MA, Nemerson $Y$. Transfer of tissue factor from leukacytes to platelets is mediated by CD15 and tissue factor. Blood. 2000;96:170-5.

17. Morrissey $\mathrm{JH}$. Tissue factor: an enzyme cofactor and a true receptor. Thromb Haemost. 2001;86:66-74.

18. Giesen PL, Rauch U, Bohrmann B, Kling D, Roque $M$, Fallon $\mathrm{JT}_{\mathrm{y}}$ Badimon $J$, Himber $J$, Riederer $M A$, Nemerson $Y$. Blood-borne tissue factor: another view of thrombosis.. Proc Natl Acad Sci U S A. 1999;96:2311-5.

19. Osterud $B$, Bjorklid $E$. The tissue factor pathway in disseminated intravascular coagulation. Semin Thromb Hemost. 2001;27:605-17.

20. Osterud $\mathrm{B}$. The role of platelets in decrypting monocyte tissue factor. Semin Hematol. 2001;38:2-5.

21. Koyama $T$, Nishida $K$, Ohdama 5 , Sawada $M$, Murakami $N$, Hirosawa $S$, Kuriyama R, Matsuzawa K, Hasegawa R, Aoki $N$. Determination of plasma tissue factor antigen and its clinical significance. Br J Haematol. 1994;87:3437.

22. Bogdanov $\mathrm{V} Y$, Balasubramanian $V$, Hathcock $J$, Vele 0 , Lieb $M$, Nemerson $Y$. Alternatively spliced human tissue factor: a circulating, soluble, thrombogenic protein. Nat Med. 2003;9:458-62.

23. Neuenschwander PF, Morrissey JH. Deletion of the membrane anchoring region of tissue factor abolishes autoactivation of factor VIl but not cofactor function. Analysis of a mutant with a selective deficiency in activity. I Biol Chem. 1992;267:14477-82.

24. Siddiqui FA, Desai $H$, Amirkhosravi A, Amaya M, Francis JL. The presence and release of tissue factor from human platelets. Platelets. 2002;13:247-53.

25. Berckmans RJ, Nieuwland R, Boing AN, Romijn FP, Hack CE, sturk A. Cell* derived microparticles circulate in healthy humans and support low grade thrombin generation. Thromb Haemost. 2001;85:639-46.

26. Engelmann B, Luther T, Muller I. Intravascular tissue factor pathway--a model for rapid initiation of coagulation within the blood vessel. Thromb Haemost. 2003;89:3-8.

27. Morrissey JH, Macik BG, Neuenschwander PF, Comp PC. Quantitation of activated factor VII levels in plasma using a tissue factor mutant selectively deficient in promoting factor VII activation. Blood. 1993;81:734-44.

28. Nemerson $Y$, Repke D. Tissue factor accelerates the activation of coagulation factor VII: the role of a bifunctional coagulation cofactor. Thromb Res. $1985 ; 40: 351-8$.

29. Rao LV, Rapaport SI. Activation of factor VII bound to tissue factor: a key early step in the tissue factor pathway of blood coagulation. Proc Natl Acad Sci US A. 1988;85:6687-91. 
30. Radcliffe $R$, Nemerson $Y$. Activation and control of factor $V I l$ by activated factor $X$ and thrombin. Isolation and characterization of a single chain form of factor VII. J Biol Chem. 1975;250:388-95.

31. Kisiel W, Fujikawa K, Davie EW. Activation of bovine factor VII (proconvertin) by factor Xlla (activated Hageman factor). Biochemistry. 1977;16:4189-94.

32. Seligsohn $U_{1}$ Osterud B, Brown SF, Griffin JH, Rapaport SI. Activation of human factor VIII in plasma and in purified systems: roles of activated factor $\mid X$, kallikrein, and activated factor XII. J Clin Invest. 1979;64:1056-65.

33. Masys DR, Bajaj SP, Rapaport SI. Activation of human factor VII by activated factors $I X$ and $X$. Blood. 1982;60:1143-50.

34. Tsujioka $H$, Suehiro $A_{\text {, }}$ Kakishita $E$. Activation of coagulation factor VII by tissue-type plasminogen activator. Am J Hematol. 1999;61:34-9.

35. Nakagaki $T$, Foster $D C$, Berkner $K L$, Kisiel W. Initiation of the extrinsic pathway of blood coagulation: evidence for the tissue factor dependent autoactivation of human coagulation factor VII. Biochemistry. 1991;30:1081924.

36. Neuenschwander PF, Fiore MM, Morrissey JH. Factor VII autoactivation proceeds via interaction of distinct protease-cofactor and zymogen-cofactor complexes. Implications of a two-dimensional enzyme kinetic mechanism. $J$ Biol Chem. 1993;268:21489-92.

37. Mosesson MW. Fibrinogen and fibrin polymerization: appraisal of the binding events that accompany fibrin generation and fibrin clot assembly. Blood Coagul Fibrinolysis. 1997;8:257-67.

38. Pieters $\rfloor$, Lindhout $T$, Hemker $H C$. In situ-generated thrombin is the only enzyme that effectively activates factor VIII and factor $V$ in thromboplastinactivated plasma. Blood. 1989;74:1021-4.

39. Alberio L, Safa O, Clemetson KJ, Esmon CT, Dale GL. Surface expression and functional characterization of alpha-granule factor $V$ in human platelets: effects of ionophore A23187, thrombin, collagen, and convulxin. Blood. 2000;95:1694-702.

40. Cawthern KM, van 't Veer $C$, Lock JB, DiLorenzo ME, Branda RF, Mann KG. Blood coagulation in hemophilia A and hemophilia C. Blood. 1998;91:4581-92.

41. Keularts $\mid M$, Zivelin A, Seligsohn U, Hemker $H C$, Beguin S. The role of factor XI in thrombin generation induced by low concentrations of tissue factor. Thromb Haemost. 2001;85:1060-5.

42. Monroe DM, Hoffman M, Roberts HR. Platelets and thrombin generation. Arterioscler Thromb Vasc Biol. 2002;22:1381-9.

43. Tanaka $M$, Suzuki $A$. Hemostatic abnormalities in acute myocardial infarction as detected by specific blood markers. Thromb Res. 1994;76:289-98.

44. Hoffmeister HM, Jur $M_{s}$ Helber $U$, Fischer $M$, Heller $W$, Seipel L. Correlation between coronary morphology and molecular markers of fibrinolysis in unstable angina pectoris. Atherosclerosis. 1999;144:151-7. 
45. Vaziri ND, Kennedy SC, Kennedy D, Gonzales E. Coagulation, fibrinolytic, and inhibitory proteins in acute myocardial infarction and angina pectoris. Am $J$ Med. $1992 ; 93: 651=7$.

46. Hoffmeister $H M$, Jur $M$, Wendel $H P$, Heller $W$, Seipel $L$. Alterations of coagulation and fibrinolytic and kallikrein-kinin systems in the acute and postacute phases in patients with unstable angina pectoris. Circulation. 1995;91:2520-7.

47. Minnema MC, Peters RJ, de Winter R, Lubbers $Y P_{3}$ Barzegar $S$, Bauer KA,

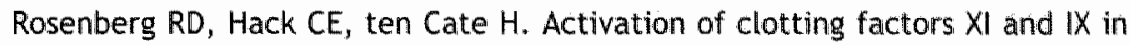
patients with acute myocardial infarction. Arterioscler Thromb Vasc Biol. $2000 ; 20: 2489-93$.

48. Mann $K G$, Butenas $S$, Brummel $K$. The dynamics of thrombin formation. Arterioscler Thromb Vasc Biol. 2003;23:17-25.

49. Rosenberg RD, Lam L. Correlation between structure and function of heparin. Proc Natl Acad Sci U S A. 1979;76:1218-22.

50. Hirsh J, Anand SS, Halperin JL, Fuster V. Guide to anticoagulant therapy: Heparin : a statement for healthcare professionals from the American Heart Association. Circulation. 2001;103:2994-3018.

51. Tollefsen DM, Majerus DW, Blank MK. Heparin cofactor II. Purification and properties of a heparin-dependent inhibitor of thrombin in human plasma. $J$ Biol Chem. 1982;257:2162-9.

52. Sadler JE. Thrombomodulin structure and function. Thromb Haemost. 1997;78:392-5.

53. Cines DB, Pollak ES, Buck CA, Loscalzo J, Zimmerman GA, McEver RP, Pober JS, Wick TM, Konkle BA, Schwartz BS, Barnathan ES, McCrae KR, Hug BA, Schmidt AM, Stern DM. Endothelial cells in physiology and in the pathophysiology of vascular disorders. Blood. 1998;91:3527-61.

54. Fair DS, Marlar RA, Levin EG. Human endothelial cells synthesize protein 5. Blood. 1986;67:1168:71.

55. Broze GJ, Jr. Tissue factor pathway inhibitor. Thromb Haemost. 1995;74:90-3.

56. Hoylaerts $M$, Rijken DC, Lijnen HR, Callen D. Kinetics of the activation of plasminogen by human tissue plasminogen activator. Role of fibrin. $J$ Biol Chem. 1982;257:2912-9.

57. Higgins DL, Vehar GA. Interaction of one-chain and two-chain tissue plasminogen activator with intact and plasmin-degraded fibrin. Biochemistry. 1987;26:7786-91.

58. Husain SS, Hasan AA, Budzynski AZ. Differences between binding of one-chain and two-chain tissue plasminogen activators to non-cross-linked and cross: linked fibrin clots. Blood. 1989;74:999-1006.

59. Lindahl $\mathrm{TL}$, Ohlsson $\mathrm{Pl}$, Wiman $\mathrm{B}$. The mechanism of the reaction between human plasminogen-activator inhibitor 1 and tissue plasminogen activator. Biochem J. 1990;265:109-13. 
60. Owensby DA, Morton PA, Wun TC, Schwartz AL. Binding of plasminogen activator inhibitor type-1 to extracellular matrix of Hep G2 cells. Evidence that the binding protein is vitronectin. J Biol Chem. 1991;266:4334-40.

61. Bajzar L, Morser J, Nesheim M. TAFI, or plasma procarboxypeptidase B, couples the coagulation and fibrinolytic cascades through the thrombinthrombomodulin complex. J Biol Chem. 1996;271:16603-8.

62. Mosnier LO, Meijers JC, Bouma BN. The role of protein 5 in the activation of thrombin activatable fibrinolysis inhibitor (TAFI) and regulation of fibrinolysis. Thromb Haemost. 2001;86:1040-6.

63. Libby $P$. Changing concepts of atherogenesis. J Intern Med. 2000;247:349-58.

64. Mallat $Z$, Hugel $B$, Ohan J, Leseche $G$, Freyssinet JM, Tedgui A. Shed membrane microparticles with procoagulant potential in human atheroscleratic plaques: a role for apoptosis in plaque thrombogenicity. Circulation. 1999;99:348-53.

65. Mallat Z, Benamer $\mathrm{H}$, Hugel B, Benessiano J, Steg PG, Freyssinet JM, Tedgui A. Elevated levels of shed membrane microparticles with procoagulant potential in the peripheral circulating blood of patients with acute coronary syndromes. Circulation. 2000;101:841-3.

66. Annex BH, Denning SM, Channon KM, Sketch MH, Jr., Stack RS, Morrissey JH, Peters KG. Differential expression of tissue factor protein in directional atherectomy specimens from patients with stable and unstable coronary syndromes. Circulation. 1995;91:619-22.

67. Ardissino D, Merlini PA, Ariens $R_{y}$ Coppola R, Bramucci E, Mannucci PM. Tissuefactor antigen and activity in human coronary atherosclerotic plaques. Lancet. 1997;349:769-71.

68. Kaikita K, Ogawa $H$, Yasue $H$, Takeya $M$, Takahashi $K$, Saito $T$, Hayasaki $K$, Horiuchi K, Takizawa A, Kamikubo $Y$, Nakamura S. Tissue factor expression on macrophages in coronary plaques in patients with unstable angina. Arterioscler Thromb Vasc Biol. 1997;17:2232-7.

69. Davies MJ. The pathophysiology of acute coronary syndromes. Heart. 2000;83:361-6.

70. Virmani R, Kolodgie FD, Burke AP, Farb A, Schwartz SM. Lessons from sudden coronary death: a comprehensive morphological classification scheme for atherosclerotic lesions. Arterioscler Thromb Vasc Biol. 2000;20:1262-75.

71. Davies MJ, Thomas AC. Plaque fissuring-the cause of acute myocardial infarction, sudden ischaemic death, and crescendo angina. Br Heart $J$. 1985;53:363-73.

72. Fuster V, Badimon L, Cohen M, Ambrose JA, Badimon JJ, Chesebro J. Insights into the pathogenesis of acute ischemic syndromes. Circulation. 1988;77:1213-20.

73. Stary $H C$, Chandler $A B$, Dinsmore RE, Fuster $V$, Glagov S, Insull $W$, Jr., Rosenfeld ME, Schwartz CJ, Wagner WD, Wissler RW. A definition of advanced 
types of atherosclerotic lesions and a histological classification of atherosclerosis. A report from the Committee on Vascular Lesions of the Council on Arteriosclerosis, American Heart Association. Circulation. 1995;92:1355-74.

74. Falk E. Unstable angina with fatal autcome: dynamic coronary thrombosis leading to infarction and/or sudden death. Autopsy evidence of recurrent mural thrombosis with peripheral embolization culminating in total vascular acclusion. Circulation. 1985;71:699-708.

75. Willerson JT, Golino P. Eidt J, Campbell WB, Buja LM. Specific platelet mediators and unstable coronary artery lesions. Experimental evidence and potential clinical implications. Circulation. 1989;80:198-205.

76. Rentrop KP. Thrombi in acute coronary syndromes: revisited and revised. Circulation. 2000;101:1619-26.

77. Early effects of tissue-type plasminogen activator added to conventional therapy on the culprit coronary lesion in patients presenting with ischemic cardiac pain at rest. Results of the Thrombolysis in Myocardial Ischemia (TIMI IllA) Trial. Circulation. 1993;87:38-52.

78. Topol EJ. Toward a new frontier in myocardial reperfusion therapy: emerging platelet preeminence. Circulation. 1998;97:211-8.

79. Blann AD, Nadar SK, Lip GY. The adhesion molecule Paselectin and cardiovascular disease. Eur Heart J. 2003;24:2166-79.

80. Stenberg PE, McEver RP, Shuman MA, Jacques $Y V$, Bainton DF. A platelet alpha-granule membrane protein (GMP-140) is expressed on the plasma membrane after activation. I Cell Biol. 1985; 101:880-6.

81. Gurbel PA, Kereiakes DJ, Serebruany VL. Soluble P-selectin is not a surrogate marker for platelet P-selectin: evidence from a multicenter chest pain study group. J Thromb Thrombolysis. 2000;10:15-22.

82. Stohlawetz $P$, Hergovich $N$, Stiegler $G$, Eichler $H G$, Hacker $P$, Kapiotis $S$, Jilma B. Differential induction of P-selectin expression on platelets by two cell separators during plateletpheresis and the effect of gender on the release of soluble P-selectin. Transfusion. 1998;38:24-30.

83. Johnson-Tidey $R R$, McGregor $J L$, Taylor $P R$, Poston $R N$. Increase in the adhesion molecule P-selectin in endothelium overlying atherosclerotic plaques. Coexpression with intercellular adhesion molecule-1. Am I Pathol. $1994 ; 144: 952-61$.

84. Tenaglia AN, Buda AJ, Wilkins RG, Barron MK, Jeffords. PR, Vo K, Jordan MO, Kusnick BA, Lefer DJ. Levels of expression of P-selectin, E-selectin, and intercellular adhesion molecule- 1 in coronary atherectomy specimens from patients with stable and unstable angina pectoris. Am J Cardiol. 1997;79:7427. 


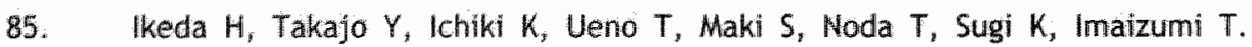
Increased soluble form of P-selectin in patients with unstable angina. Circulation. 1995; $92: 1693-6$.

86. Itoh $T$, Nakal $K_{\mathrm{s}}$ Ono $M$, Hiramori $K$. Can the risk for acute cardiac events in acute coronary syndrome be indicated by platelet membrane activation marker P-iselectin? Coron Artery Dis. 1995;6:645-50.

87. Maly $M$, Vojacek J, Hrabos V, Kvasnicka J, Salaj $P$, Durdil V. Tissue factor, tissue factor pathway inthbitor and cytoadhesive molecules in patients with an acute coronary syndrome. Physiol Res. 2003;52:719-28.

88. Blann AD, Faragher EB, McCollum CN. Increased soluble P-selectin following myocardial infarction: a new marker for the progression of atherosclerosis. Blood Coagul Fibrinolysis. 1997;8:383-90.

89. Menown IB, Mathew TP, Gracey HM, Nesbitt GS, Murray P, Young IS, Adgey AA. Prediction of Recurrent Events by D-Dimer and Inflammatory Markers in Patients with Normal Cardiac Troponin I (PREDICT) Study. Am Heart $J$. 2003;145:986-92.

90. Hollander JE, Muttreja MR, Dalesandro MR, Shofer FS. Risk stratification of emergency department patients with acute coronary syndromes using $P$ selectin. I Am Coll Cardiol. 1999;34:95-105.

91. Hillis GS, Terregino C, Taggart P, Killian A, Zhao N, Dalsey WC, Mangione A. Elevated soluble $P$-sellectin levels are associated with an increased risk of early adverse events in patients with presumed myocardial ischemia. Am Heart J. 2002;143:235-41.

92. Mulvihill NT, Foley JB, Murphy RT, Curtin R, Crean PA, Walsh M. Risk stratification in unstable angina and non- $Q$ wave myocardial infarction using soluble cell adhesion molecules. Heart. 2001;85:623-7.

93. Malik I, Danesh $J$, Whincup P, Bhatia V, Papacosta $O$, Walker $M$, Lennon $L$, Thomson A, Haskard D. Soluble adhesion molecules and prediction of coronary heart disease: a prospective study and meta-analysis. Lancet. 2001;358:971-6.

94. Serebruany VL, Levine DJ, Nair GV, Meister AF, Gurbel PA. Usefulness of combining necrosis and platelet markers in triaging patients presenting with chest pain to the emergency department. J Thromb Thrombolysis. 2001;11:155-62.

95. Albrecht $S$, Luther $T$, Grossmann H, Flossel $C$, Kotzsch M, Muller M. An ELISA for tissue factor using monoclonal antibodies. Blood Coagul Fibrinolysis. $1992 ; 3 * 263-70$.

96. Suefuji $H$, Ogawa $H$, Yasue $H$, Kaikita $K$, Soejîma $H$, Motoyama $T$, Mizuno $Y$, Oshima $S$, Saito T, Tsuji I, Kumeda K, Kamikubo $Y$, Nakamura S. Increased plasma tissue factor levels in acute myocardial infarction. Am Heart $J$. $1997: 134: 253-9$.

97. Falciani M, Gori AM, Fedi S, Chiarugi L, Simonetti I, Dabizzi RP, Prisco D, Pepe G. Abbate R, Gensini GF, Neri Serneri GG. Elevated tissue factor and tissue 
factor pathway inhibitor circulating levels in ischaemic heart disease patients. Thromb Haemost. 1998; 79:495-9.

98. Takahashi $H$, Satoh $N_{\text {, Wa }}$ Wa Takakuwa $E$, Seki $Y$, Shibata $A$. Tissue factor in plasma of patients with disseminated intravascular coagulation. Am J Hematol. 1994;46:333-7.

99. Fareed J, Callas DD, Hoppensteadt D, Bermes EW, Jr. Tissue factor antigen levels in various biological fluids. Blood Coagul Fibrinolysis. 1995;6 Suppl $1:$ :S32-6.

100. Albrecht S, Kotzsch M, Siegert G, Luther T, Grossmann H, Grosser M, Muller M. Detection of circulating tissue factor and factor VII in a normal population. Thromb Haemost. 1996;75:772-7.

101. Francis $\mathrm{JL}$, Carvalho $M$, Francis DA. The clinical value of tissue factor assays. Blood Coagul Fibrinolysis. 1995;6 Suppl 1:S37-44.

102. Carty N, Taylor $\Vdash$, Roath OS, el-Baruni $K$, Francis JL. Urinary tissue factor activity in malignancy. Thromb Res. 1990;57:473-8.

103. Bukovsky A, Labarrere CA, Haag B, Carter C, Faulk WP. Tissue factor in normal and transplanted human kidneys. Transplantation. 1992;54:644-50.

104. Misumi $K$, Ogawa $H$, Yasue $H$, Soejima $H$, Suefuji $H$, Nishyama $K$, Takazoe $K$, Kugiyama K, Tsuji I, Kumeda K, Nakamura S. Comparison of plasma tissue factor levels in unstable and stable angina pectoris. Am J Cardiol. 1998;81:226.

105. Miyamoto S, Ogawa H, Sakamoto T, Soejima H, Takazoe K, Shimomura H, Kajiwara I, Yoshimura $M$, Kugiyama $K$, Nakamura S, Ozaki Y. Platelet hyperaggregability persists even after the improvement of increased blood coagulation and impaired fibrinolysis with the stabilization of symptoms in patients with unstable angina. Int $J$ Cardiol. 2001;80:235-42.

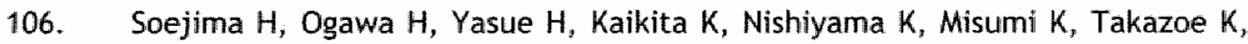
Miyao $Y$, Yoshimura $M$, Kugiyama $K$, Nakamura $S$, Tsuji $\|$, Kumeda $K$. Heightened tissue factor associated with tissue factor pathway inhibitor and prognosis in patients with unstable angina. Circulation. 1999;99:2908-13.

107. Gori AM, Pepe G, Attanasio M, Falciani M, Abbate R, Prisco D, Fedi S, Giusti B, Brunelli $T$, Comeglio P, Gensini GF, Neri Serneri GG. Tissue factor reduction and tissue factor pathway inhibitor release after heparin administration. Thromb Haemost. 1999;81:589-93.

108. Marco J, Ariens RA, Fajadet J, Bossi IM, Marco I, Bernies M, Romano SM, Donatelli F, Brambilla GM, Somalvico F, Mari D, Gregorini L. Effect of aspirin and tilclopidine on plasma tissue factor levels in stable and unstable angina pectoris. Am J Cardiol. 2000;85:1527-31.

109. He $M$, Wen $Z$, He X, Xiong $S$, Liu $F, X u J$, Li J, Xie $Q$, Jian $Z$, Chen $F$, Xiao $B, P u$ $X$, He $S$. Obserwation on tissue factor pathway and some other coagulation parameters during the onset of acute cerebrocardiac thrombotic diseases. Thromb Res. 2002;107:223-8. 
110. Yamamoto $N$, Ogawa $H$, Oshima $S$, Soejima $H$, Fujif $H$, Misumi $K$, Takazoe $K$, Mizuno $Y$, Noda $K$, Saito T, Tsuji I, Kumeda K, Nakamura S, Yasue H. The effect of heparin on tissue factor and tissue factor pathway inhibitor in patients with acute myocardial infarction. Int J Cardiol. 2000;75:267-74.

111. Santucci RA, Erlich $d$, Labriola $J$, Wilson $M$, Kao KJ, Kickler TS, Spillert $C$, Mackman N. Measurement of tissue factor activity in whole blood. Thromb Hoinost. 2000;83:445-54.

112. Fukuda $C$, lijima $K$, Nakamura K. Measuring tissue factor (factor Ill) activity in plasma. Clin Chem. 1989;35:1897-900.

113. lijima K, Fukuda C, Nakamura K. Measurements of tissue factor-like activity in plasma of patients with DiC. Thromb Res. 1991;61:29-38.

114. Nieuwland R, Berckmans RJ, Rotteveel-Ejikman RC, Maquelin KN, Roozendaal

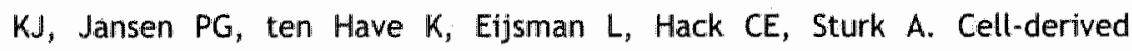
microparticles generated in patients during cardiopulmonary bypass are highly procoagulant. Circulation. 1997;96:3534-41.

115. Key NS, Slungaard A, Dandelet L, Nelson SC, Moertel C, Styles LA, Kuypers FA, Bach RR. Whole blood tissue factor procoagulant activity is elewated in patients with sickle cell disease. Blood. 1998;91:4216-23.

116. Wielders S, Mukherjee M, Michiels J, Rijkers DT, Cambus JP, Knebel RW, Kakkar V, Hemker HC, Beguin S. The routine determination of the endogenous thrombin potential, first results in different forms of hyper- and hypocoagulability. Thromb Haemost. 1997;77:629-36.

117. Abumiya $T$, Enjyoji $K$, Kokawa $T$, Kamikubo $Y$, Kato $H$. An anti-tissue factor pathway inhibitor (TFPI) monoclonal antibody recognized the third Kunitz domain (K3) of free-form TFPI but not lipoprotein-associated forms in plasma. J Biochem (Tokyo). 1995;118:178-82.

118. Hansen JB, Huseby KR, Huseby NE, Ezban M, Nordoy A. Tissue factor pathway inthibitor in complex with low density lipoprotein isolated from human plasma does not possess anticoagulant function in tissue factor-induced coagulation in vitro. Thromb Res. 1997;85:413-25.

119. Novotny WF, Girard T.J, Miletich JP, Broze GJ, Jr. Purification and characterization of the lipoprotein-associated coagulation inhibitor from human plasma. J Biol Chem. 1989;264:18832-7.

120. Novotny WF, Girard TJ, Milletich JP, Broze GJ, Jr. Platelets secrete a coagulation inhibitor functionally and antigenically similar to the lipoprotein associated coagulation inhibitor. Blood. 1988;72:2020-5.

121. Broze GJ, Jr., Lange GW, Duffin KL, MacPhail L. Heterogeneity of plasma tissue factor pathway inhibitor. Blood Coagul Fibrinolysis. 1994;5:551-9.

122. Sandset PM, Abildgaard U, Larsen ML. Heparin induces release of extrinsic coagulation pathway inhibitor (EPI). Thromb Res. 1988;50:803-13. 
123. Novotny WF, Brown $5 G$, Miletich JP, Rader DJ, Broze GJ, Jr. Plasma antigen levels of the lipoprotein-associated coagulation inhibitor in patient samples. Blood. 1991;78:387-93.

124. Sandset PM, Abildgaard U. Extrinsic pathway inhibitor--the key to feedback control of blood coagulation initiated by tissue thromboplastin. Haemostasis. $1991 ; 21: 219-39$.

125. Hubbard AR, Weller LJ, Gray E. Measurement of tissue factor pathway inhibitor in normal and post-heparin plasma. Bload Coagul Fibrinolysis. 1994;5:819-23.

126. Jeske W, Hoppensteadt $D$, Fareed J, Bermes E. Measurement of functional and immunologic levels of tissue factor pathway inhibitor. Some methodologic considerations. Blood Coagul Fibrinolysis. 1995;6 Suppl 1:S73-80.

127. Bognacki J, Hammelburger J. Functional and immunologic methods for the measurement of human tissue factor pathway inhibitor. Blood Coagul Fibrinolysis. 1995;6 Suppl 1:S65-72.

128. Lindahl AK, Abildgaard U, Larsen ML, Staalesen R, Hammer AK, Sandset PM, Nordfang $\mathrm{O}$, Beck TC. Extrinsic pathway inhibitor (EPI) relleased to the blood by heparin is a more powerful coagulation inhibitar than is recombinant EPI. Thromb Res. $1991 ; 62: 607-14$.

129. Wun TC, Huang MD, Kretzmer KK, Palmier MO, Day KC, Bulock JW, Fok KF, Broze GJ, Jr. Immunoaffinity purification and characterization of lipoproteinassociated coagulation inhibitors from Hep G2 hepatoma, Chang liver, and SK hepatoma cells. A comparative study. J Biol Chem. 1990;265:16096-101.

130. Kamikura $Y$, Wada H, Yamada A, Shimura M, Hiyoyama K, Shiku H, Tanigawa M, Nishikawa $H$, Yamada N, Isaka N, Nakano T, Kumeda K, Kato H. Increased tissue factor pathway inhibitor in patients with acute myocardial infarction. Am J Hematol. 1997;55:183-7.

131. Sandset PM, Larsen ML, Abildgaard U, Lindahl AK, Odegaard OR. Chromogenic substrate assay of extrinsic pathway inhibitor (EPI): levels in the normal population and relation to cholesterol. Blood Coagul Fibrinolysis. 1991;2:42533.

132. He $X$, Wen $Z$, Xiong $S$, He $M$, Li J, He $S$. Studies on an assay for functional tissue factor pathway inhibitor antigen. Chin J Thromb Hemostat. 2001;7:9. 12.

133. Gerotziafas GT, Zafiropoulos A, Van Dreden P, Karavaggeli E, Goutzoumas N, Nikolaidis $P$, Combot $C$, Lagoudaki $P$, Zervas $K$, Arzoglou $P$, Samama MM. Inhibition of factor VIla generation and prothrombin activation by treatment with enoxaparin in patients with unstable angina. $\mathrm{Br} \perp$ Haematol. $2003 ; 120: 611-7$.

134. Palmier MO, Hall LJ, Reisch CM, Baldwin MK, Wilson AG, Wun TC. Clearance of recombinant tissue factor pathway inhibitor (TFPI) in rabbits. Thromb Haemost. 1992;68:33-6. 
135. Warshawsky I, Bu $G$, Mast $A$, Saffitz JE, Broze $G J$, Jr., Schwartz AL. The carboxy terminus of tissue factor pathway inhibitor is required for interacting with hepatoma cells in vitro and in vivo. J Clin Invest. 1995;95:1773-81.

136. Narita $M, B u G$, Olins GM, Higuchi DA, Herz J, Broze GJ, Jr., Schwartz AL. Two receptor systems are involved in the plasma clearance of tissue factor pathway inhibitor in vivo. J Biol Chem. 1995;270:24800-4.

137. Crawley J, Lupu F, Westmuckett AD, Severs NJ, Kakkar VV, Lupu C. Expression, locatization, and activity of tissue factor pathway inhibitor in normal and atherosclerotic human vessels. Arterioscler Thromb Vasc Biol. 2000;20:1362:73.

138. Drew AF, Davenport P, Apostolopoulos J, Tipping PG. Tissue factor pathway inhibitor expression in atherosclerosis. Lab Invest. 1997;77:291-8.

139. Teitel JM, Bauer KA, Lau HK, Rosenberg RD. Studies of the prothrombin activation pathway utilizing radioimmunoassays for the $F 2 / F 1+2$ fragment and thrombin--antithrombin complex. Blood. 1982;59:1086-97.

140. Boisclair MD, Lane DA, Philippou H, Sheikh S, Hunt B. Thrombin production, inactivation and expression during open heart surgery measured by assays for activation fragments including a new ELISA for prothrombin fragment $F 1+2$. Thromb Haemost. 1993;70:253-8.

141. Pelzer $H$, Schwarz $A$, Heimburger $N$. Determination of human thrombinantithrombin III complex in plasma with an enzyme-linked immunosorbent assay. Thromb Hoemost. 1988;59:101-6.

142. Tripodi A, Chantarangkul V, Bottasso B, Mannucci PM. Poor comparabillity of prothrombin fragment $1+2$ values measured by two commercial ELISA methods: influence of different anticoagulants and standards. Thromb Haemost. 1994;71:605-8.

143. Bauer KA, Barzegar 5, Rosenberg RD. Influence of anticoagulants used for blood collection on plasma prothrombin fragment $\mathrm{F} 1+2$ measurements. Thromb Res. 1991;63:617-28.

144. Merlini PA, Bauer KA, Oltrona L, Ardissino D, Cattaneo M, Belli $C$, Mannucci $P M$, Rosenberg RD. Persistent activation of coagulation mechanism in unstable angina and myocardial infarction. Circulation. 1994;90:61-8.

145. Miller GJ, Bauer KA, Barzegar S, Foley AJ, Mitchell JP, Cooper JA, Rosenberg RD. The effects of quality and timing of venepuncture on markers of blood coagulation in healthy middle-aged men. Thromb Haemost. 1995;73:82-6.

146. Bauer KA, Goodman TL, Kass BL, Rosenberg RD. Elevated factor Xa activity in the blood of asymptomatic patients with congenital antithrombin deficiency. $J$ Clin Irvest. 1985;76:826-36.

147. Merlini PA, Ardissino D, Bauer KA, Oltrona L, Pezzano A, Bottasso B, Rosenberg $\mathrm{RD}$, Mannucci PM. Persistent thrombin generation during heparin therapy in patients with acute coronary syndromes. Arterioscler Thromb Vasc Biol. $1997 ; 17: 1325-30$. 
148. Ardissino D, Merlini PA, Bauer KA, Galvani M, Ottani $F$, Franchi $F$, Bertocchi $F$, Rosenberg RD, Mannucci PM. Coagulation activation and long-term outcome in acute coronary syndromes. Blood. 2003;102:2731-5.

149. Lopez Y, Paloma MJ, Rifon J, Cuesta B, Paramo JA. Measurement of prethrombotic markers in the assessment of acquired hypercoagulable states. Thromb Res. 1999;93:71-8.

150. Manten A, de Winter RJ, Minnema MC, ten Cate H, Lijmer JG, Adams R, Peters RJ, van Deventer SJ. Procoagulant and proinflammatory activity in acute coronary syndromes. Cardiovasc Res: 1998;40:389-95.

151. Bayes-Genis A, Mateo J, Santalo M, Oliver A, Guindo J, Badimon L, MartinezRubio A, Fontcuberta $J$, Schwartz RS, De Luna AB. D-Dimer is an early diagnostic marker of coronary ischemia in patients with chest pain. Am Heart J. $2000 ; 140: 379-84$.

152. Fiotti $N$, Di Chiara A, Altamura N, Miccio $M$, Fioretti P, Guarnieri G, Giansante C. Coagulation indicators in chronic stable effort angina and unstable angina: relationship with acute phase reactants and clinical outcome. Blood Coagul Fibrinolysis. 2002;13:247-55.

153. Philippou $H$, Adami A, Amersey RA, Stubbs PJ, Lane DA. A novel specific immunoassay for plasma two-chain factor VIla: investigation of FVlla levels in normal individuals and in patients with acute coronary syndromes. Blood. 1997;89:767-75.

154. Li YH, Teng JK, Tsai WC, Tsai LM, Lin LJ, Guo HR, Chen JH. Prognostic significance of elevated hemostatic markers in patients with acute myocardial infarction. I Am Coll Cardiol. 1999;33:1543-8.

155. Merlini PA, Ardissino D, Oltrona L, Broccolino $M$, Coppola $R$, Mannucci PM. Heightened thrombin formation but normal plasma levels of activated factor VIII in patients with acute coronary syndromes. Arterioscler Thromb Vasc Biol. $1995 ; 15: 1675-9$.

156. Scharfstein JS, Abendschein DR, Eisenberg PR, George D, Cannon CP, Becker RC, Sobel B, Cupples LA, Braunwald $E$, Loscalzo J. Usefulness of fibrinogenolytic and procoagulant markers during thrombolytic therapy in predicting clinical outcomes in acute myocardial infarction. TIMI-5 Investigators. Thrombolysis in Myocardial Infarction. Am $J$ Cardiol. $1996 ; 78: 503-10$.

157. Giannitsis $E$, Siemens HJ, Mitusch R, Tettenborn $\|$, Wiegand $U$, Schmucker $G$, Sheikhzadeh A, Stierle $U$. Prothrombin fragments $F 1+2$, thrombin-antithrombin III complexes, fibrin monomers and fibrinogen in patients with coronary atherosclerosis. Int J'Cardiol. 1999;68:269-74.

158. Giannitsis E, Bardorff MM, Schweikart S, Wiegand U, Kampmann M, Katus HA. Relationship of cardiac troponin $T$ and procoagulant activity in unstable angina. Thromb Haemost. 2000;83:224-8. 
159. Al-Obaidi MK, Philippou H, Stubbs PJ, Adami A, Amersey R, Noble MM, Lane DA. Relationships between homocysteine, factor Vlla, and thrombin generation in acute coronary syndromes. Circulation. 2000;101:372-7.

160. Vogel CN, Kingdon HS, Lundblad RL. Correlation of in vivo and in vitro inhibition of thrombin by plasma inhibitors. I Lab Clin Med. 1979;93:661-73.

161. Shifman MA, Pizzo SV. The in vivo metabolism of antithrombin III and antithrombin III complexes. I Biol Chem. 1982;257:3243-8.

162. Gold HK, Torres FW, Garabedian HD, Werner W, Jang IK, Khan A, Hagstrom $J N$, Yasuda $T$, Leinbach $R C$, Newell $J B$, et al. Evidence for a rebound coagulation phenomenon after cessation of a 4-hour infusion of a specific thrombin inhibitor in patients with unstable angina pectoris. $J \mathrm{Am}$ Coll Cardiol. 1993;21:1039-47.

163. Bauer KA. Activation markers of coagulation. Baillieres Best Pract Res Clin Haematol. 1999;12:387-406.

164. Seitz R, Blanke H, Pratorius G, Strauer BE, Egbring R. Increased thrombin activity during thrombolysis. Thromb Haemost. 1988;59:541-2.

165. Granger CB, Becker R, Tracy RP, Califf RM, Topol EJ, Pieper KS, Ross AM, Roth S, Lambrew $C$, Bovill EG. Thrombin generation, inhibition and clinical outcomes in patients with acute myocardial infarction treated with thrombolytic therapy and heparin: results from the GUSTO-I Trial. GUSTO-I Hemostasis Substudy Group. Global Utilization of Streptokinase and TPA for Occluded Coronary Arteries. J Am Coll Cardial. 1998;31:497-505.

166. Watanabe $R$, Wada $H$, Sakakura M, Mori $Y$, Nakasaki $T$, Okugawa $Y$, Gabazza EC, Hayashi T, Nishioka J, Suzuki K, Shiku H, Nobori T. Plasma levels of activated protein $C$-protein $C$ inhibitor complex in patients with hypercoagulable states. Am J Hematol. 2000;65:35-40.

167. Ardissino D, Gamba MG, Merlini PA, Rolla A, Barberis P, Demicheli G, Testa S, Bruno N, Specchia G. Fibrinopeptide A excretion in urine: a marker of the cumulative thrombin activity in stable versus unstable angina patients. Am $J$ Cardiol. $1991 ; 68: 58 \mathrm{~B}-63 \mathrm{~B}$.

168. Blomback B, Blomback $M$, Edman P, Hessel B. Human fibrinopeptides. Isolation, characterization and structure. Biochim Biophys Acta. 1966:115:371-96.

169. Kockum C, Frebelius S. Rapid radioimmunoassay of human fibrinopeptide A . removal of cross-reacting fibrinogen with bentonite. Thromb Res. 1980;19:589-98.

170. Alkjaersig N, Fletcher AP. Catabolism and excretion of fibrinopeptide-A. Blood. 1982;60:148-56.

171. van Hulsteijn $\mathrm{H}$, Kolff J, Briet $E$, van der Laarse A, Bertina R. Fibrinopeptide A and beta thromboglobulin in patients with angina pectoris and acute myocardial infarction. Am Heart J. 1984;107:39-45. 
172. Mombelli G, Im Hof V, Haeberli A, Straub PW. Effect of heparin on plasma fibrinopeptide $A$ in patients with acute myocardial infarction. Circulation. $1984 ; 69: 684-9$.

173. Hofmann V, Straub PW. A radioimmunoassay technique for the rapld measurement of human fibrinopeptide A. Thromb Res. 1977;11:171-81.

174. Gallino A, Haeberli A, Straub PW. Fibrinopeptide A excretion in urine in patients with atherosclerotic artery disease. Thromb Res. 1985;39:237-44.

175. Gallino A, Haeberli A, Baur HR, Straub PW. Fibrin formation and platelet aggregation in patients with severe coronary artery disease: relationship with the degree of myocardial ischemia. Circulation. 1985;72:27-30.

176. Eisenberg PR, Sherman LA, Jaffe AS. Paradoxic elevation of fibrinopeptide A after streptokinase: evidence for continued thrombosis despite intense fibrinolysis. J Am Coll Cardial. 1987;10:527-9.

177. Kockum C. Radioimmunoassay of fibrinopeptide A-clinical applications. Thromb Res. 1976;8:225-36.

178. Theroux P, Latour JG, Leger-Gauthier C, De Lara J. Fibrinopeptide A and platelet factor levels in unstable angina pectoris. Circulation. 1987;75:156-62.

179. Lee LV, Ewald GA, Mckenzie CR, Eisenberg PR. The relationship of soluble fibrin and cross-linked fibrin degradation products to the clinical course of myocardial infarction. Arterioscler Thromb Vasc Biol. 1997;17:628-33.

180. Wilensky RL, Zeller JA, Wish M, Tulchinsky $M$. Urinary fibrinopeptide A levels in ischemic heart disease. I Am Coll Cardiol. 1989;14:597-603.

181. Doolittle RF. Structural aspects of the fibrinogen to fibrin conversion. Adv Protein Chem. 1973;27:1-109.

182. Doolittle RF. Fibrinogen and fibrin. Sci Am. 1981;245:126-35.

183. Shainoff $J R$, Page $\mathrm{IH}$. Significance of cryoprofibrin in fibrinogen-fibrin Conversion. J Exp Med. 1962;116:687-707.

184. Brass EP, Forman WB, Edwards RV, Lindan O. Fibrin formation: the role of the fibrinogen-fibrin monomer complex. Thromb Haemost. 1976;36:37-48.

185. Graeff $H$, Hafter $R$, von Hugo $R$. On soluble fibrinogen-fibrin complexes. Thromb Res. 1979;16:575-6.

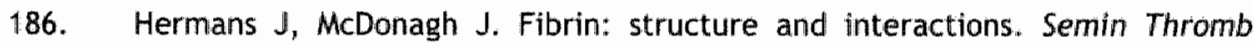
Hemost. 1982;8:11-24.

187. Kruskal JB, Commerford PJ, Franks JJ, Kirsch RE. Fibrin and fibrinogenrelated antigens in patients with stable and unstable coronary artery disease. N Engl J Med. 1987;317:1361-5.

188. Terres W, Kummel P, Sudrow A, Reuter H, Meinertz T, Hamm CW. Enhanced coagulation activation in troponin $\mathrm{T}$-positive unstable angina pectoris. Am Heart J. 1998;135:281-6.

189. Hamm CW, Ravkilde J, Gerhardt W, Jorgensen $P$,Peheim E, Ljungdahl $\mathbb{L}_{\text {, }}$ Goldmann B, Katus HA. The prognostic value of serum troponin $T$ in unstable angina. N Engl J Med. 1992;327:146-50. 
190. Ravkilde 1 , Horder $M$, Gerhardt $W$, Ljungdahl L, Pettersson $T$, Tryding $\mathbb{N}_{\text {, }}$ Moller BH, Hamfelt A, Graven T, Asberg A, et al. Diagnostic performance and prognostic value of serum troponin $T$ in suspected acute myocardial infarction. Scond I Clin Lab Invest. $1993 ; 53 ; 677-85$.

191. Carville DG, Dimitrijevic $N$, Walsh $M$, Digirolamo $\pi$, Brill EM, Drew $N$, Gargan $P E$. Thrombus precursor protein (TpP): marker of thrombosis early in the pathogenesis of myocardial infarction. Clin Chem. 1996;42:1537-41.

192. Hermens WT, Pelsers MM, Mullers-Boumans ML, de Zwaan C, Glatz JF. Combined use of markers of muscle necrosis and fibrinogen conversion in the early differentiation of myocardial infarction and unstable angina. Clin Chem. 1998;44:890-2.

193. Laurino JP, Pelletier TE, Eadry R, Kounavis A. Thrombus Precursor Protein and the measurement of thrombosis in patients with acute chest pain syndrome. Ann Clin Lab Sci. 1997;27:338-45.

194. Derhaschnig U, Laggner AN, Roggla M, Hirschl MM, Kapiotis S, Marsik C, Jilma $B$. Evaluation of coagulation markers for early diagnosis of acute coronary syndromes in the emergency room. Clin Chem. 2002;48:1924-30.

195. Takada $Y$, Takada A. Measurements of the concentration of free plasminogen activator inhibitor (PAl-1) and its complex with tissue plasminogen activator in human plasma. Thromb Res Suppl. 1988;8:15-22.

196. Takada A, Shizume K, Ozawa T, Takahashi 5, Takada Y. Characterization of various antibodies against tissue plasminogen activator using highly sensitive enzyme immunoassay. Thromb Res. 1986;42:63-72.

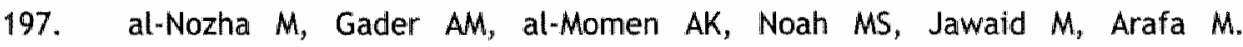
Haemostatic variables in patients with unstable angina. Int $J$ Cardiol. 1994;43:269-77.

198. Zalewski A, Shi $Y$, Nardone D, Bravette B, Weinstock P, Fischman D, Wilson P, Goldberg $S$, Levin DC, Bjornsson TD. Evidence for reduced fibrinolytic activity in unstable angina at rest. Clinical, biochemical, and angiographic correlates. Circulation. 1991;83:1685-91.

199. Collet JP, Montalescot G, Vicaut E, Ankri A, Walylo F, Lesty C, Choussat R, Beygui $F$, Borentain $M$, Vignolles. $N$, Thomas $D$. Acute release of plasminogen activator inhibitor-1 in ST-segment elevation myocardial infarction predicts mortality. Circulation. 2003;108:391-4.

200. Soeki T, Tamura $Y$, Fukuda $N$, Ito $S$. Plasma and platelet plasminogen activator inhibitor-1 in patients with acute myocardial infarction.. Jpn Circ J. 2000;64:547-53.

201. Munkvad S, Jespersen J, Gram J, Kluft C. Interrelationship between coagulant activity and tissue-type plasminogen activator (t-PA) system in acute ischaemic heart disease. Possible role of the endothelium. I Intern Med. $1990 ; 228: 361-6$. 
202. Wiman B, Hamsten A. Correlations between fibrinolytic function and acute myocardial infarction. Am J Cardiol: 1990;66:54G-56G.

203. Hamsten A, Wiman B, de Faire $U$, Blomback $M$. Increased plasma levels of a rapid inhibitor of tissue plasminogen activator in young survivors of myocardial infarction. N Engl J Med. 1985;313:1557-63.

204. Munkvad S, Gram J, Jespersen J. A depression of active tissue plasminogen activator in plasma characterizes patients with unstable angina pectoris who develop myocardial infarction. Eur Heart J. 1990;11:525-8.

205. Ridker PM, Vaughan DE, Stampfer MJ, Manson JE, Hennekens $\mathrm{CH}$. Endogenous tissue-type plasminogen activator and risk of myocardial infarction. Lancet. 1993;341:1165-8.

206. Meade TW, Ruddock $V$, Stirling $Y$, Chakrabarti $R$, Miller GJ. Fibrinolytic activity, clotting factors, and long-term incidence of ischaemic heart disease in the Northwick Park Heart Study. Lancet. 1993;342:1076-9.

207. Hamsten A, de Faire U, Walldius G, Dahlen G, Szamosi A, Landou C, Blomback $M$, Wiman $B$. Plasminogen activator inhibitor in plasma: risk factor for recurrent myocardial infarction. Lancet. 1987;2:3-9.

208. Jansson JH, Olofsson BO, Nilsson TK. Predictive value of tissue plasminogen activator mass concentration on long-term mortality in patients with coronary artery disease. A 7-year follow-up. Circulation. 1993;88:2030-4.

209. Jansson $\mathrm{JH}$, Nilsson TK, Olofsson BO. Tissue plasminogen activator and other risk factors as predictors of cardiowascular events in patients with severe angina pectoris. Eur Heart J. 1991;12:157-61.

210. Jansson $J H$, Nilsson $T K$, Johnson $O$. von Willebrand factor in plasma: a novel risk factor for recurrent myocardial infarction and death. Br Heart $J$. $1991 ; 66: 351-5$.

211. Juhan-Vague I, Pyke SD, Alessi MC, Jespersen J, Haverkate F, Thompson 5 G. Fibrinalytic factors and the risk of myocardial infarction or sudden death in patients with angina pectoris. ECAT Study Group. European Concerted Action on Thrombosis and Disabilities. Circulation. 1996;94:2057-63.

212. Francis CW, Connaghan DG, Scatt WL, Marder VJ. Increased plasma concentration of cross-linked fibrin polymers in acute myocardial infarction. Circulation. 1987;75:1170-7.

213. van Beek EJ, van den Ende B, Berckmans RJ, van der Heide YT, Brandjes DP, Sturk $A$, ten Cate JW. A comparative analysis of D-dimer assays in patients with clinically suspected pulmonary embolism. Thromb Haemost. $1993 ; 70: 408-13$.

214. Hart R, Bate I, Dinh D, Elms $M$, Bundesen P, Hillyard C, Rylatt DB. The detection of $D$-dimer in plasma by enzyme immunoassay: improved discrimination is obtained with a more specific signal antibody. Blood Coagul Fibrinalysis. 1994;5:227-32. 
215. Stein PD, Hull RO, Patel KC, Olson RE, Ghali WA, Brant R, Biel RK, Bharadia V, Kalra NK. D-dimer for the exclusion of acute venous thrombosis and pulmonary embolism: a systematic review. Ann Intern Med. 2004;140:589-602.

216. Marder VJ, Zareba W, Horan JT, Moss AJ, Kanouse JJ. Automated latex agglutination and ELISA testing yield equivalent D-dimer results in patients with recent myocardial infarction. THROMBO Research Investigators. Thromb Haemost: 1999;82:1412-6.

217. Lip GY, Lowe GD. Fibrin D-dimer: a Liseful clinical marker of thrombogenesis? Clin Sci (Lond). 1995;89:205-14.

218. Abe S, Maruyama I, Arima S, Yamaguchi H, Okino $H$, Hamasaki S, Yamashita T, Nomoto $K$, Tahara $M$, Atsuchi $Y$, et al. Increased heparin-releasable platelet factor 4 and $D$ dimer in patients one month after the onset of acute myocardial infarction: persistent activation of platelets and the coagulation/fibrinolytic system. Int $J$ Cardiol. 1994;47:57-12.

219. Moss AJ, Goldstein RE, Marder VJ, Sparks CE, Oakes D, Greenberg H, Weiss HJ, Zareba $W$, Brown MW, Liang CS, Lichstein E, Little WC, Gillespie JA, Van Voorhees L, Krone RJ, Bodenheimer MM, Hochman J, Dwyer EM, Jr., Arora R, Marcus FI, Watelet LF, Case RB. Thrombogenic factors and recurrent coronary events. Circulation. 1999;99:2517-22.

220. Hunter WM, Greenwood FC.. Preparation of iodine-131 labelled human growth hormone of high specific activity. Nature. 1962;194:495-6.

221. Boisclair MD, Lane DA, Wilde $J T$, Ireland $H$, Preston FE, Ofosu FA. A comparative evaluation of assays for markers of activated coagulation and/or fibrinolysis: thrombin-antithrombin complex, D-dimer and fibrinogen/fibrin fragment $\mathrm{E}$ antigen. Br J Haematol. 1990;74:471-9.

222. Raimondi $P$, Bongard $O$, de Moerloose $P$, Reber $G$, Waldvogel $F$, Bounameaux $H$. D-dimer plasma concentration in various clinical conditions: implication for the use of this test in the diagnostic approach of venous thromboembolism. Thromb Res. 1993;69:125-30.

223. Bauer KA, Weiss LM, Sparrow D, Vokonas PS, Rosenberg RD. Aging-associated changes in indices of thrombin generation and protein $\mathrm{C}$ activation in humans. Normative Aging Study. J Clin Invest. 1987;80:1527-34.

224. Mari D, Mannucci PM, Coppola R, Bottasso B, Bauer KA, Rosenberg RD. Hypercoagulability in centenarians: the paradox of successful aging. Blood. $1995 ; 85: 3144-9$.

225. Bauer KA, Kass $B L$, ten Cate $H$, Hawiger JJ, Rosenberg RD. Factor $I X$ is activated in vivo by the tissue factor mechanism. Blood. 1990;76:731-6.

226. Bartsch $P_{3}$. Haeberli A, Straub PW. Blood coagulation after long distance running: antithrombin III prevents fibrin formation. Thromb Haemost. 1990;63:430-4.

227. Miller GJ, Bauer KA, Cooper JA, Rosenberg RD. Activation of the coagulant pathway in cigarette smokers. Thromb Haemost. 1998;79:549-53. 
228. Caine YG, Bauer KA, Barzegar $S$, ten Cate $H$, Sacks FM, Watsh BW, Schiff 1 , Rosenberg RD. Coagulation activation following estrogen administration to postmenopausal women. Thromb Haemost, 1992;68:392-5.

229. Wilkes HC, Meade TW, Barzegar S, Foley AJ, Hughes LO, Bauer KA, Rosenberg RD, Miller GJ. Gemfibrozil reduces plasma prothrombin fragment $F 1+2$ concentration, a marker of coagulability, in patients with coronary heart disease. Thromb Haemost. 1992;67:503-6.

230. Miller GJ, Martin JC, Mitropoulos KA, Esnouf MP, Cooper JA, Morrissey JH, Howarth $D J$, Tuddenham EG. Activation of factor VII during alimentary lipemia occurs in healthy adults and patients with congenital factor XII or factor XI deficiency, but not in patients with factor IX deficiency. Blood. 1996;87:4187 96.

231. Silveira A, Karpe F, Johnsson H, Bauer KA, Hamsten A. In vivo demonstration in humans that large postprandial triglyceride-rich lipoproteins activate coagulation factor VII through the intrinsic coagulation pathway. Arterioscler Thromb Vasc Biol. 1996;16:1333-9.

232. Kapur R, Hoffman $\mathrm{CJ}$, Bhushan V, Haltin MB. Postprandial elevation of activated factor VII in young adults. Arterioscler Thromb Vasc Biol. 1996;16:1327-32.

233. Weinstein MJ, Chute LE, Schmitt GW, Hamburger RH, Bauer KA, Troll JH, Janson $P$, Deykin D. Abnormal factor VIII coagulant antigen in patients with renal dysfunction and in those with disseminated intravascular coagulation. $J$ Clin Invest. 1985;76:1406-11.

234. Mair J, Genser N, Maier J, Lechleitner P, Dienstl F, Puschendorf B. Markers of activated coagulation for early diagnosis of acute myocardial infarction. Clin Chim Acta. 1997;267:239-45. 


\section{CHAPTER 3}

\section{HIGH-AFFINITY ANTIBODIES IN A NEW ELISA FOR PLASMA TISSUE FACTOR. REDUCTION OF APPARENT INTRA-INDIVIDUAL VARIATION}

RFM van der Putten ${ }^{1}, \mathrm{H}$ te Velthuis ${ }^{2}$, LA Aarden ${ }^{2}{ }, \mathrm{H}$ ten Cate ${ }^{1}$, JFC Glatz ${ }^{1}$ and WT Hermens ${ }^{\dagger}$

${ }^{1}$ Cardiovascular Research Institute Maastricht (CARIM), Maastricht University, Maastricht, the Netherlands

${ }^{2}$ Sanquin Research, Department of Immunopathology and Laboratory for Experimental and Clinical Immunology, University of Amsterdam, Amsterdam, the Netherlands

Provisionally accepted for publication in Clinical Chemistry and Laboratory Medicine 


\section{$>$ ABSTRACT}

Tissue Factor (TF), the main initiator of blood coagulation, is shed into plasma by various cell types, such as blood cells and endothelium. While studying plasma TF with a commercially available TF assay, we found unsatisfactory results and therefore we developed a new and highly sensitive ELISA.

High-affinity monoclonal antibodies, raised against recombinant soluble TF, were used and the new assay had a detection limit of $40 \mathrm{fM}$. Normal ranges in 20 healthy donors were established in serum and in citrated, EDTA, and heparinized plasma. Also, TF was measured in 3 successive plasma samples from 43 patients with type 2 diabetes mellitus.

In citrated plasma from healthy donors, TF concentrations were 2.5 (1.09.3) $\mathrm{pM}$ (median with range), and were not significantly different in diabetics. With a commercially available ELISA, 7 plasma samples from diabetics were below the detection limit. Using the new assay, intraindividual variation in diabetic patients was $14 \%$, versus $49 \%$ for the commercial assay. It is concluded that the new assay had markedly improved performance. 
Tissue Factor (TF), an integral membrane glycoprotein, is the main initiator of blood coagulation. It is present in blood cells and in the vascular wall and, after vascular injury, exposure of TF to blood causes formation of the membrane-associated TF-Vlla complex, which subsequently activates factor $X$ as well as factor $\mid X$, and ultimately causes platelet activation and thrombus formation ${ }^{1,2}$. TF is also present in plasma ${ }^{3}$, where it is probably associated to microparticles shed from blood cells 4,5 or injured atherosclerotic plaques ${ }^{6}$. In addition, a soluble form of alternatively-spliced human TF (ashTF) has been demonstrated in plasma ${ }^{7}$. Such ashTF was proposed to bind to thrombi and thereby to propagate clotting.

Plasma TF levels are commonly determined by using enzyme-linked immunosorbent assays (ELISAS), and several laboratory and commercially available ELISAS have been described in the literature. Triggered by unsatisfactory results obtained by one of these assays, especially in the normal range of plasma TF concentrations, the aim of the present work was to develop a highly sensitive and accurate ELISA for the measurement of TF concentrations in plasma.

\section{MATERIALS AND METHODS}

\section{Plasma and serum from healthy donors and diabetic patients}

The study was performed in conformance with the Declaration of Helsinki ethical guidelines and approved by local Ethical Committees. After informed consent, venous blood samples were taken from 20 healthy donors of the Sanquin Bloodtransfusion Service, Maastricht, 11 men and 9 women with a median age of 43 (15-64) years. Following standard donation of $500 \mathrm{~mL}$ blood, blood samples were collected in Vacutainer glass tubes containing either sodium citrate, potassium EDTA or sodium heparin. Plasma was obtained by routine centrifugation for $6 \mathrm{~min}$ at $2500 \mathrm{~g}$ at room temperature. Serum samples were collected after clotting, by centrifugation for $12 \mathrm{~min}$ at $1850 \mathrm{~g}$. Samples were immediately aliquoted and stored at $-80^{\circ} \mathrm{C}$.

After informed consent, citrated plasma was also obtained from 43 diabetic patients who were recruited from the Slotervaart Hospital, Amsterdam, the Netherlands. These patients were diagnosed with type 2 diabetes for at least 1 year and participated in a study of the effect of a cholesterol-lowering drug, pravastatin, on plasma coagulation and inflammation markers, as described by Sommeijer et al. ${ }^{8}$. Briefly, one-half of the subjects started with $40 \mathrm{mg} /$ day of pravastatin while the other half remained untreated, with a crossover after 8 weeks followed by another 8 
weeks of treatment. Plasma samples were obtained on day 1 and after 8 and 16 weeks. Samples were immediately aliquoted and stored at $-80^{\circ} \mathrm{C}$ for further analysis.

\section{Materials}

High-affinity (dissociation constant $K_{d}-10^{-11} \mathrm{M}$ ), non-competing, antibodies CLB/TF-5 and CLB/TF-1, raised against recombinant human soluble TF (Chiron Corp., Emeryville, CA), were obtained from Sanquin Research, Amsterdam, and recognized endogenous TF exposed on TNF-stimulated endothelial cells (data not shown). Biotinylation of CLB/TF-1 was performed with EZ Link Sulpho-NHS-LC biotin of Pierce at a biotin:antibody ratio of $600: 1$. Recombinant soluble tissue factor (sTF, residues $1-219, M_{\mathrm{r}}=26.8 \mathrm{kD}$ ) was produced in $E$. coli as described ${ }^{9}$. Recombinant full-length human TF, in 0.01\% 3-([3-Cholamidopropyl]-dimethylammonio)-1-propanesulfonate (CHAPS), was from American Diagnostica Inc., Greenwich, CT (Product No. 4500). This protein was visualized at $43 \mathrm{kD}$ on SDS-gel electrophoresis. Poly-HRP conjugated Streptavidin (enzyme/protein-ratio 20) was also obtained from Sanquin Research, Amsterdam. Skimmed milk powder (Vremini 'Excellent' Non-Fat Dry Milk or NFDM) was from Vreugdenhil BV (Voorthuizen, the Netherlands). Bovine serum albumin (BSA, purity $98-99 \%$, fatty acid-free) was from ICN Biomedicals Inc., Aurora, $\mathrm{OH}$.

Total protein concentrations were measured with the Micro-BCA kit, Pierce Chemical Company, Rockford, IL. Affigel-15 agarose beads for the covalent coupling of proteins were purchased from Bio-Rad Laboratories, Hercules, CA. Triton X-100 (Triton) was from Sigma Chemical Company, St. Louis, MO. The HRP substrate 3,3',5,5'-tetramethylbenzidine (TMB) was from Kirkegaard \& Perry Laboratories Inc., Gaithersburg, MD. Nunc-immuno plates, type Maxisorp, were from Nalge Nunc International, Rochester, NY. Phosphate-buffered saline (PBS) contained $10 \mathrm{mM}$ PBS and $150 \mathrm{mM} \mathrm{NaCl}, \mathrm{pH}$ 7.4. PBST buffer was PBS buffer containing $0.2 \%$ (vol/vol) Tween-20. HEPESbuffered saline (HBS) contained $25 \mathrm{mM} \mathrm{N}$-2-hydroxyethylpiperazine- $\mathrm{N}^{*}$-2ethanesulfonic acid (HEPES) and $175 \mathrm{mM} \mathrm{NaCl}, \mathrm{pH}$ 7.7. High Performance ELISA buffer (HPE), designed to reduce background signal in ELISAs using biotin-(strept)avidin amplification, was from Sanquin Reagents, Amsterdam, the Netherlands. All chemicals used were of the highest grade available.

\section{Covalent coupling of TF antibody to Affigel-15 beads}

After washing Affigel-15 with cold deionized water, monoclonal TFantibody $(0.2 \mathrm{mg}$ of CLB/TF-1 per $\mathrm{mL}$ of gel) was coupled to Affigel-15 in 0.2 $M \mathrm{NaHCO}_{3}$, supplemented with $0.5 \mathrm{M} \mathrm{NaCl}, \mathrm{pH} 8.5$, by rotating the mixture end-over-end for $2 \mathrm{~h}$ at room temperature. The remaining reactive groups on the gel were blocked by the addition of $100 \mu \mathrm{L}$ of $1 \mathrm{M}$ ethanolamine, $\mathrm{pH} 8.0$, 
and another hour of rotation. To remove excess uncoupled antibody, the gel was washed 5 times with, alternatively, $0.5 \mathrm{M}$ ethanolamine supplemented with $0.5 \mathrm{M} \mathrm{NaCl}, \mathrm{pH} 8.3$, and $0.1 \mathrm{M}$ sodium acetate supplemented with $0.5 \mathrm{M}$ $\mathrm{NaCl}, \mathrm{pH} 4.0$. Finally, the gel was equilibrated in $\mathrm{HBS}$ containing $0.2 \%$ sodium azide and stored at $4^{\circ} \mathrm{C}$.

\section{Tissue factor ELISA}

Nunc-immuno plates were coated overnight at $4^{\circ} \mathrm{C}$ with $100 \mu \mathrm{L}$ of $5 \mu \mathrm{g} / \mathrm{mL}$ capture antibody CLB/TF-5 in $100 \mathrm{mM}$ sodium carbonate, $\mathrm{pH}$ 9.6. After washing 5 times with PBST, plasma samples were diluted 5 -fold in HPE buffer containing 1 vol\% of Triton, and $100 \mu \mathrm{L}$ of diluted plasma or STF was added to the wells. After adding $10 \mu \mathrm{L}$ of $5.5 \mu \mathrm{g} / \mathrm{mL}$ biotinylated CLB/TF-1 antibody, the plate was incubated for $2 \mathrm{~h}$ at room temperature on a shaker and then washed 5 times with PBST. Thereafter $100 \mu \mathrm{l}$ of poly-HRP conjugated Streptavidin $(0.1 \mu \mathrm{g} / \mathrm{ml})$ in PBS with $5 \mathrm{~g} / \mathrm{L}$ NFDM was added and incubated for another 20 min. After washing 5 times with PBST, $100 \mu \mathrm{L}$ of TMB substrate was added and after 15-20 min the reaction was stopped by the addition of $5 \%$ sulfuric acid. Optical absorption at $450 \mathrm{~nm}$ was read on a Benchmark microplate reader (Bio-Rad Laboratories, Hercules, CA). Recombinant sTF was used as calibrator. The recovery of plasma spiked with sTF was $100 \%$ (data not shown). Intra- and interassay imprecision of a control plasma ( $3.3 \mathrm{pM})$ were $2.6 \%$ and $13.3 \%(n=8)$. The detection limit, defined as $>99$ percentile of blank values, was $40 \mathrm{fM}(\mathrm{n}=10)$.

\section{Comparison with a commercial ELISA for plasma TF}

Because of its frequent use in the literature, we used the Imubind TF ELISA (Product No. 845) from American Diagnostica Inc., Greenwich, CT, according to the instructions of the manufacturer. Wash buffer (PBS with $0.1 \%$ Triton) was included in the kit. Plasma samples were diluted 10 -fold in wash buffer with 1 w\% of BSA, and $100 \mu \mathrm{L}$ samples of diluted plasma were incubated in wells pre-coated with anti-human TF capture antibody for 3 hours at room temperature. Following 4 times washing with buffer, $100 \mu \mathrm{L}$ of biotinylated anti-human TF $F\left(\mathrm{ab}^{\prime}\right)_{2}$ fragment was added and incubated for $1 \mathrm{~h}$ at room temperature. After washing again 4 times with buffer, $100 \mu \mathrm{L}$ HRP-conjugated Streptavidin was added and incubated for another hour at room temperature. Finally, after washing another 4 times, $100 \mu \mathrm{L}$ of TMB substrate (provided in the kit) was added. Following incubation for $20 \mathrm{~min}$ at room temperature the reaction was stopped by the addition of $50 \mu \mathrm{L}$ of $0.5 \mathrm{M}$ sulfuric acid. Recombinant full-length human TF was used as calibrator. TF concentrations were converted to $\mathrm{pM}$ by using a molecular weight of $43 \mathrm{kD}$. As indicated in the package insert, the detection limit of the assay is approximately 10 $\mathrm{pg} / \mathrm{mL}$, but assay imprecision and normal plasma range were not recorded. 


\section{Statistics}

Values are presented as mean \pm SD or as medians with total range between brackets for non-Gaussian distributed values. Significances of differences were tested by using the Kruskal-Wallis or the 2-way MannWhitney test, and correlations were calculated by using the Spearman correlation coefficient, for non-Gaussian distributed values (GraphPad Prism version 4.00 for Windows, GraphPad Software, San Diego, CA, USA).

\section{$>$ RESULTS}

\section{Purity and recovery from plasma of the ELISA calibrator}

To check the purity of the STF calibrator, $20 \mu \mathrm{g} / \mathrm{mL}$ of sTF (as determined with the total protein assay) in PBS was incubated with $0.5 \mathrm{~mL}$ CLB/TF1coated Affigel- 15 at room temperature. After 1 hour, only $10 \%$ of total protein and 13\% of TF antigen (as determined in the ELISA) was found in the supernatant. Assuming a $K_{d}$ for binding of TF to CLB/TF-1 of $10^{-11} \mathrm{M}$ (see Methods), it can be calculated that the bound fraction will be $89 \%$, in accordance with the $90-87 \%$ observed $(n=3)$. It was concluded that the STF in the ELISA calibrator was $100 \%$ antigenic. Recovery of plasma spiked with sTF was also $100 \%$ (data not shown).

\section{Calibration curves for the two ELISAs}

As shown in Figure 1, the calibration curve of the new ELISA was linear in the whole concentration range studied, whereas the calibrator curve of the commercial ELISA deviated from linearity, in agreement with the example shown in the package insert. The STF calibrator of the new ELISA also produced a linear response in the Imubind assay (data not shown), but the Imubind calibrator hardly produced any signal in the new ELISA. This was probably caused by some unknown additive to the Imubind calibrator, because for the full-length human TF from American Diagnostica used as a calibrator in this assay, a linear response was again obtained in the new ELISA.

\section{Plasma TF concentrations in healthy donors}

In one healthy donor we found outlying TF concentrations of $50 \mathrm{pM}, 226$ pM, 237 pM and 177 pM for citrated, EDTA, heparinized plasma and serum, respectively. In addition, this patient's plasma showed similar outlying values in a monoclonal-based ELISA for fatty acid-binding protein, a marker for myocardial injury, but not in an ELISA for prothrombin fragment 1+2, a marker for activated coagulation, based on rabbit antibodies (data not shown). It was concluded that this plasma probably contained anti-mouse IgG antibodies ${ }^{10}$ and this donor was excluded from further analyses. 
For the remaining 19 individuals, median TF concentrations with total ranges were $2.5(1.0-9.3) \mathrm{pM}, 3.4(2.2-17.6) \mathrm{pM}$ and $3.4(2.4-19.2) \mathrm{pM}$ for citrated, EDTA and heparinized plasma, respectively, and $2.8(1.3-9.8) \mathrm{pM}$ for serum. These values were not significantly different, indicating that clotting, in spite of its effects on platelets and other blood cells, did not cause cellular TF release into plasma. Individual TF concentrations are shown in Figure 2.

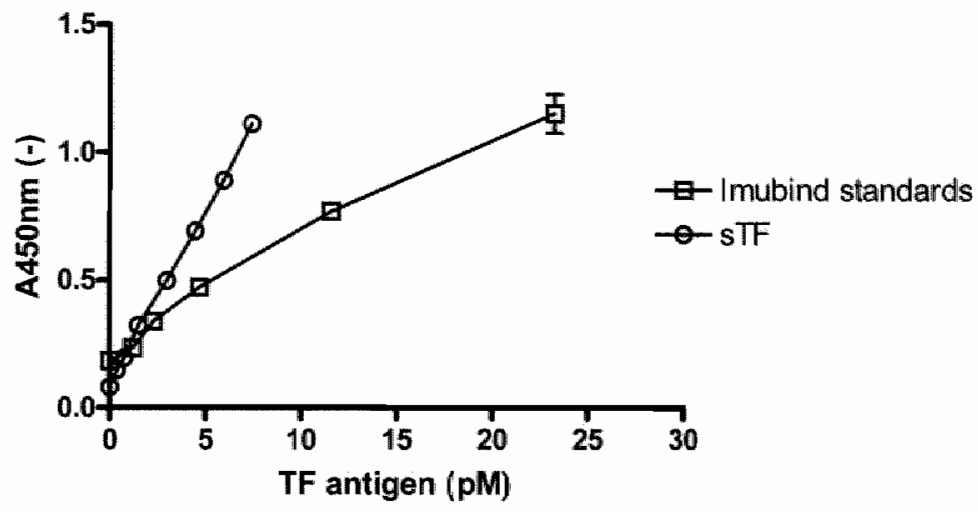

Figure 1. Calibration curves for TF assays. Calibration curves for soluble TF (new ELISA) and the Imubind calibrators (commercial ELISA).

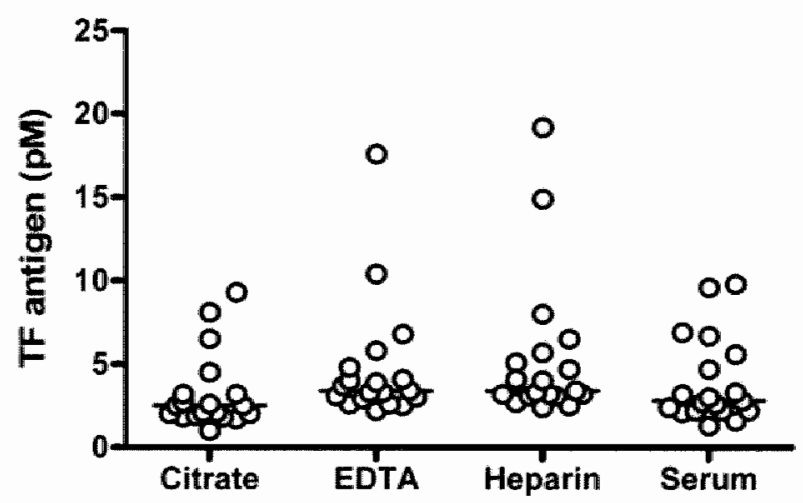

Figure 2. TF concentrations in healthy donor plasma. TF concentrations for citrated, EOTA and heparinized plasma, and for serum in 19 healthy donors. Median values are indicated by bars. 
Performance of the ELISAs in patients with type 2 diabetes

For the commercial ELISA, seven plasma samples were below the detection limit, which was about 6 times higher $(10 \mathrm{pg} / \mathrm{mL}$, or about $230 \mathrm{fM})$ than for the new ELISA. No effect of pravastatin on plasma TF concentrations was found $(p=0.81$ for the new ELISA, and $p=0.85$ for the commercial ELISA). Also, for all three time points, TF concentrations in diabetic patients were not significant different from those in healthy controls. Median TF concentrations in diabetics (and total range between brackets) are shown in Table 1. Although there is a tendency to slightly higher concentrations as found by the new ELISA, the difference became only significant for the 16 weeks time point.

\section{Intra-individual TF variation in diabetic patients}

Intra-individual variation in TF over the 16-week period was calculated for citrated plasma samples. Figure 3 (left panel) presents TF concentrations as measured at the three time points of sampling. Intra-individual variation (right panel) was shown by expression of the TF concentrations on day 1, after 8 weeks and after 16 weeks, as percentage of the average value for the three time points. Intra-individual variation (plus assay scatter) on day 1 , after 8 weeks and after 16 weeks was $16 \%, 13 \%$ and $13 \%$ for the new ELISA and $56 \%$, $47 \%$ and $43 \%$ for the commercial ELISA, respectively. The average intraindividual variation of $14 \%$ for the new ELISA is almost totally explained by the $13 \%$ assay imprecision (see Methods), indicating that the true intra-individual variation will be even smaller. This also implies that in this normal range of plasma TF concentrations the commercial ELISA had about $49 \%$ assay scatter.

\section{Correlation between the two ELISAs}

Figure 4 shows the relation between TF concentrations measured by the two ELISAs. For all 129 (3x43) plasma samples from the diabetic patients (left panel), the Spearman correlation coefficient was $0.353 \quad(p<0.0001)$. After exclusion of 6 samples with outlying values (right panel), the Spearman coefficient of correlation was $0.443(p<0.0001)$.

Table 1. Plasma TF concentrations $(\mathrm{PM})$ in patients with type 2 diabetes

\begin{tabular}{ccc}
\hline Median (range) & New Elisa & Commercial ELISA \\
\hline Day 1 & $3.0(0.9-24.1)$ & $2.6(0.1-24.3)$ \\
8 weeks & $3.0(0.8-25.3)$ & $2.6(0-6.9)$ \\
16 weeks & $3.0(1.3-15.8)^{*}$ & $2.6(0-7.2)$ \\
\hline
\end{tabular}

* Significantly different between the two ELISAS $(p=0.027)$. 

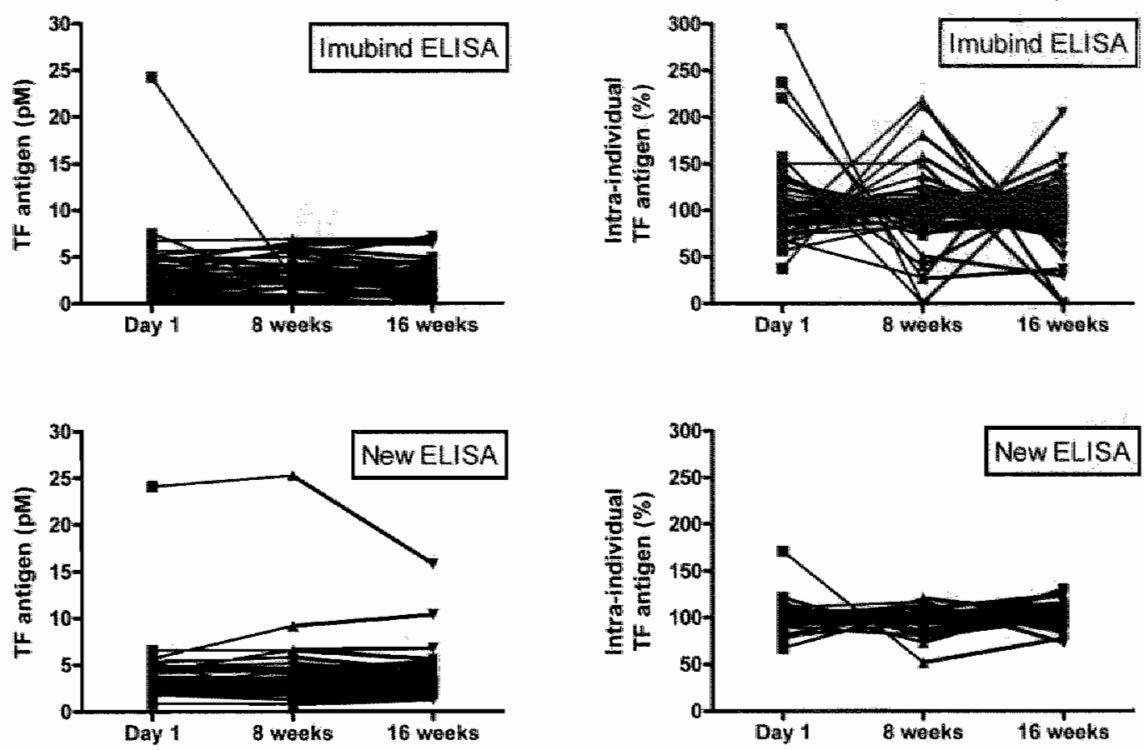

Figure 3. TF concentrations in 43 diabetic patients over a 16-week period. TF concentrations, measured with the two ELISAS at three different time points, are shown in the left panel. The right pamel shows the same values, expressed as a percentage of the averaged three values.
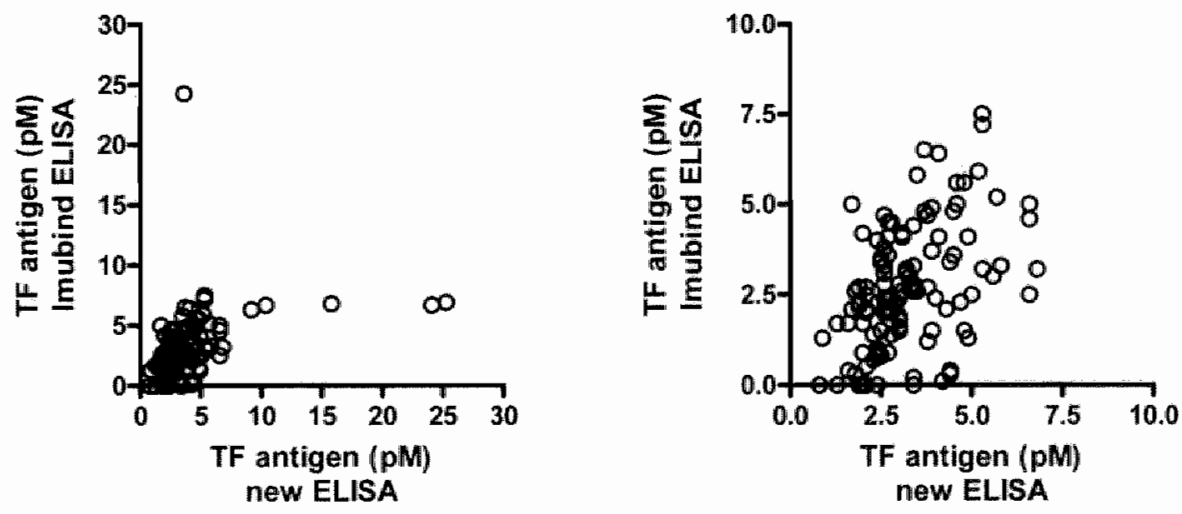

Figure 4. Correlation between TF concentrations as measured by the two ELISAS. Plasma TF concentrations as measured in 43 diabetic patients ( 3 samples per patient) are shown in the left figure, with 6 outlying values omitted in the right figure. 


\section{$>$ DISCUSSION}

The present study describes a new ELISA for the measurement of TF, which can be used for plasma with citrate, EDTA or heparin as anticoagulants, as well as for serum. Compared to an often used commercial assay, the new ELISA showed improved sensitivity with a steeper and linear calibration curve and a detection limit of $40 \mathrm{fM}$. In addition, assay imprecision was much lower, as evidenced by a large reduction of apparent intra-individual variation.

The median value of $2.5 \mathrm{pM}$, as found in the present study for citrated plasma from healthy donors, corresponded to an average value of $3.2 \mathrm{pM}$. Using a value of $47,000 \mathrm{~g} / \mathrm{mol}$ for the molar mass of glycosylated, full-length $T F$, the latter value corresponds to $150 \mathrm{pg} / \mathrm{ml}$, in agreement with the range of $125-175 \mathrm{pg} / \mathrm{mL}$ earlier reported for average TF concentrations in citrated plasma of healthy controls $11,12,13,14$. This quantitative agreement between different ELISAs, using a variety of antibodies, indicates that plasma TF is protected from proteolytic fragmentation as demonstrated for circulating tissue proteins like creatine kinase and enolase ${ }^{15}$, or troponin $T^{16}$. Recently, we also found more direct evidence for intact plasma TF by demonstrating that the bulk of plasma TF circulates in (potentially) functional state (Van der Putten et al., British Journal of Haematology, in press).

Plasma TF has been reported to be incorporated into shed membrane vesicles ${ }^{4,5}$ and thereby could be partly 'encrypted' or hidden from the catcher antibodies. We therefore added detergent ( 1 vol\% of Triton) to our dilution buffer. However, no differences in TF concentrations as measured with and without Triton were found, indicating that all plasma TF was actually exposed. Because in some pathological conditions, such as TF release from freshly ruptured plaque, such encryption could still occur, we maintained the use of Triton in our assay. The new ELISA will also recognize the recently discovered alternatively-spliced soluble TF variant, which was reported to constitute about $30 \%$ of total plasma TF ${ }^{7}$, because the CLB/TF-1 and CLB/TF5 antibodies used in our assay were raised against soluble TF.

It should be noted that plasma samples in ELISAs usually must be diluted. In the present case, such dilution was 10 times for the commercial assay, as indicated by the manufacturer. So the range of $11.8(4.7-43.7) \mathrm{pg} / \mathrm{mL}$ in the 10 times diluted plasma of the healthy donors did fall around the detection limit of $10 \mathrm{pg} / \mathrm{ml}$ of the assay and it is not surprising that some of these concentrations could not be determined. For the new ELISA dilution was 5 times and the actual TF concentrations in the diluted samples thus were $0.5(0.2-1.9) \mathrm{pM}$, well above the detection limit of $40 \mathrm{fM}$. Also, a large apparent intra-individual variation of $49 \%$ of the commercial assay is not surprising for measurements around the detection limit, and it follows from the present study that the true intra-individual variation is probably less than 
10\%. The large imprecision of the commercial assay also explained the low Spearman correlation coefficients of 0.4 to 0.5 .

The main advantages of using high-affinity antibodies in ELISAS are to allow detection of lower concentrations of antigen and shorter incubation times, which improves sensitivity, and to make the assay relatively insensitive to variations in catcher density and to washing, which improves accuracy. The first aspect is self-evident, because the high affinity, and corresponding high binding rate constant, will allow better and more rapid extraction of antigen from plasma, especially at low antigen concentrations. The second aspect results from the fact that high rate constants for binding will make the adsorption rate of antigen to the catcher-coated surface transport-limited, and no longer dependent on the (variations in) catcher surface density. Washing will cause some desorption of conjugate from the antigen, as well as desorption of antigen-conjugate complexes from the catcher, but for high binding rate constants, a desorbed molecule will have a much higher chance of being readsorbed than of being washed away ${ }^{17}$.

\section{ACKNOWLEDGEMENTS}

The authors would like to thank Prof. J. Morrissey (University of Illinois College of Medicine, Urbana, IL, USA) for providing soluble tissue factor and Dr. D. Sommeijer for providing the plasma samples from type 2 diabetic patients. This work was supported by research grants 98.063 and 2002B189 from the Netherlands Heart Foundation. Jan FC Glatz is Netherlands Heart Foundation Professor. 


\section{$>$ REFERENCES}

1. Nemerson Y. Tissue factor: then and now. Thromb Haemost. 1995;74:180-4.

2. Morrissey JH. Tissue factor modulation of factor Vlla activity: use in measuring trace concentrations of factor Vila in plasma. Thromb Haemost. 1995;74:1858.

3. Giesen $\mathrm{PL}$, Rauch $\mathrm{U}$, Bohrmann $\mathrm{B}$, Kling $\mathrm{D}$, Roque $\mathrm{M}$, Fallon JT, et al.. Bloodborne tissue factor: another view of thrombosis. Proc Natl Acad Sci USA. 1999;96:2311-5.

4. Ryan J, Brett J, Tijburg P, Bach RR, Kisiel W, Stern D. Tumor necrosis factorinduced endothelial tissue factor is associated with subendothelial matrix vesicles but is not expressed on the apical surface. Blood. 1992;80:966-74.

5. Schecter $A D$, Giesen $P L$, Taby $O$, Rosenfield $C L$, Rossikhina M, Fyfe BS, et all. Tissue factor expression in human arterial smooth muscle cells. TF is present in three cellular pools after growth factor stimulation. $J$ Clin Invest. 1997; 100:2276-85.

6. Mallat $Z$, Hugel $B$, Ohan J, Leseche G, Freyssinet JM, Tedgui A. Shed membrane microparticles with procoagulant potential in human atherosclerotic plaques: a role for apoptosis in plaque thrombogenicity. Circulation. 1999;99:348-53.

7. Bogdanov VY, Balasubramanian V, Hathcock J, Vele O, Lieb M, Nemerson $Y$. Alternatively spliced human tissue factor: a circulating, soluble, thrombogenic protein. Nat Med. 2003;9:458-62.

8. Sammeijer DW, MacGillavry MR, Meijers JC, Van Zanten AP, Reitsma PH, Ten Cate $\mathrm{H}$. Anti-inflammatory and anticoagulant effects of pravastatin in patients with type 2 diabetes. Diabetes Care. 2004;27:468-73.

9. Rezaie AR, Fiore MM, Neuenschwander PF, Esmon CT, Morrissey JH. Expression and purification of a soluble tissue factor fusion protein with an epitope for an unusual calcium-dependent antibody. Protein Expr Purif. 1992;3:453-60.

10. Kricka LJ. Human anti-animal antibody interferences in immunological assays. Clin Chem. 1999;45:942-56.

11. Suefuji $H$, Ogawa $H$, Yasue $H$, Kaikita $K$, Soejima $H$, Motoyama, et al. Increased plasma tissue factor levels in acute myocardial infarction. Am Heart J. 1997;134:253-9.

12. Albrecht $S$, Kotzsch $M$, Siegert $G$, Luther $T$, Grossmann $H$, Grosser $M$, et al. Detection of circulating tissue factor and factor VII in a normal population. Thromb Haemost. 1996;75:772-7.

13. Falciani $M$, Gori AM, Fedi $S$, Chiarugi L, Simonetti I, Dabizzi RP, et al. Elevated tissue factor and tissue factor pathway inhibitor circulating levels in ischaemic heart disease patients. Thromb Haemost. 1998;79:495-9. 
14. Maly $M$, Vojacek J, Hrabos V, Kvasnicka $J$, Salaj P, Durdil V. Tissue factor, tissue factor pathway inhibitor and cytoadhesive molecules in patients with an acute coronary syndrome. Physiol Res. 2003;52:719-28.

15. Van Landeghem AA, Soons JB, Wever RA, Mul-Steinbusch MW, Antonissen-Zijda T. Purification and determination of the modifying protein responsible for the post-synthetic modification of creatine kinase (EC 2.7.3.2) and enolase (EC 4.2.1.11). Clin Chim Acta. 1985;153:217-24.

16. Diris JHC, Hackeng $C M$, Kooman JP, Pinto $Y M$, Hermens WTh, van DieijenVisser M. Impaired renal clearance explains elevated troponin $T$ fragments in hemodialysis patients. Circulation. 2004;109:23-5.

17. Hermens WT, Benes $M$, Richter $R$, Speijer $H$. Effects of flow on solute exchange between fluids and supported biosurfaces. Biotechnol Appl Biochem. 2004; 39: 277-84. 


\section{CHAPTER 4}

\section{QUANTITATIVE COMPARISON OF THE CONCENTRATIONS OF TISSUE FACTOR ANTIGEN AND TISSUE FACTOR ACTIVITY IN PLASMA AND SERUM OF HEALTHY DONORS}

RFM van der Putten ${ }^{1}, \mathrm{H}$ te Velthuis ${ }^{2}$, PLA Giesen ${ }^{3}, \mathrm{JH}$ Morrissey ${ }^{4}$, LA Aarden ${ }^{2}$, JFC Glatz ${ }^{1}$ and WT Hermens ${ }^{1}$

${ }^{1}$ Cardiovascular Research Institute Maastricht (CARIM), Maastricht University, Maastricht, the Netherlands

${ }^{2}$ Sanquin Research, Department of Immunopathology and Laboratory for Experimental and Clinical Immunology, University of Amsterdam, Amsterdam, the Netherlands

${ }^{3}$ Synapse BV, Maastricht, the Netherlands

${ }^{4}$ University of Illinois College of Medicine, Urbana, IL, USA 


\section{$>$ ABSTRACT}

Plasma tissue factor (TF) antigen levels of 2.6-3.7 pM have been reported for healthy controls, and such amounts of active TF could cause acute thrombosis. We therefore investigated the quantitative relation between TF antigen and (potential) TF activity in plasma and serum of healthy donors.

To avoid the problems involved in measurement of TF activity in whole plasma, a capture assay for TF activity was developed, using a high-affinity anti-TF antibody, bound to Affigel. The TF eluted from the gel was reconstituted in phospholipid-glucoside micelles, avoiding time-consuming dialysis. Full-length recombinant human TF was used as activity calibrator and, by determination of its $k_{\text {cat }}$, allowed expression of activities in mol/L $(M)$ of active protein, with a detection limit of $80 \mathrm{fM}$.

For comparability, the same antibody, together with another high-affinity anti-TF antibody, was used in a new ELISA for TF antigen. Recombinant soluble TF (STF) was used as calibrator and the resulting assay had a detection limit of $40 \mathrm{fM}$.

All plasma TF was found to be exposed for capture and, in citrated plasma, TF antigen and (reconstituted) TF activity was $2.5(1.0-9.3) \mathrm{pM}$ and $2.0(1.3-4.2) \mathrm{pM}$ (median with range), respectively. In contrast to citrated or EDTA plasma, serum or heparinized plasma did not allow measurement of activity. When left in its in vivo state, captured TF was totally inactive, probably due to the absence of procoagulant phospholipids. The high potential activity of plasma TF suggests a physiological role in case of tissue injury. 
Tissue Factor (TF), an integral membrane glycoprotein, is the main initiator of blood coagulation. It is present in the vascular wall and in blood cells and, according to the classical concept, vascular injury will cause exposure of TF to blood and will lead to the formation of membraneassociated TF-VIla complexes, which then cause production of thrombin, platelet activation, and thrombus formation ${ }^{1,2}$.

Concentrations of $125-175 \mathrm{pg} / \mathrm{mL}$ or, using a molecular mass of $47 \mathrm{kD}$ for full-length, glycosylated TF, of 2.6-3.4 pM of TF antigen are reported in plasma of healthy individuals (see Discussion), while only a small fraction of this amount of active TF may cause acute in vitro clotting of plasma ${ }^{3}$. Apparently, TF antigen circulates in plasma in an exposed but inactivated form. For instance, an alternatively-spliced form of human TF (ashTF) has recently been found in plasma ${ }^{4}$ but, because of the lack of a membranebinding region, such soluble forms only have a few percent of the activity of lipidated full-length TF ${ }^{5}$. More recently, however, fully active TF was extracted from plasma and reconstituted in procoagulant phospholipid vesicles ${ }^{6}$. This finding suggested a new role for plasma TF ${ }^{7,8}$.

Several groups have tried to assess the significance of blood-borne TF relative to vascular wall-TF under physiological conditions. Chou et al. ${ }^{9}$ found that TF on hematopoietic cell-associated microparticles contributed significantly to thrombus propagation. However, Day et al. ${ }^{10}$ found that thrombus formation following either carotid artery injury or inferior vena caval ligation was driven primarily by vascular wall-TF as opposed to bloodborne TF. Although these studies have demonstrated that at least some circulating TF is in intact, functional form, quantitative measurement of TF activity in plasma has been hampered by the many positive and negative feedback loops in the coagulation system.

To avoid such problems we developed a new assay, based on the earlier described ${ }^{6}$ capture of TF from plasma with an anti-TF antibody coupled to Affigel. In contrast to this earlier method, and to a recent similar application ${ }^{11}$, the new assay does not require a dialysis step for reconstitution of the activity of TF eluted from the gel, and thus allows rapid determination. Application of the same reconstitution protocol on full-length recombinant human TF, and measurement of the catalytic rate constant $k_{\text {cat }}$, then allowed the expression of measured activities in absolute amounts (mol/L) of active protein.

For comparability of results, the same antibody was used in a new ELISA for TF antigen. To confirm that the TF thus measured constituted not only a fraction of the total amount present in plasma, it was verified that the measured concentrations agreed with earlier estimates of plasma TF antigen 
in healthy controls, as reported in the literature for a variety of immunoassays.

As an integral membrane protein, plasma TF has been demonstrated to circulate in a lipid-embedded state . An important issue in the literature is whether plasma TF is 'encrypted'. In the present study we found no effects of detergent for both assays, indicating that all plasma TF is exposed. We also found evidence, however, indicating that TF embedded in a procoagulant matrix may immediately become encrypted in plasma. Together, these findings suggest that the total inactivity we found for TF captured from plasma when left in its in vivo state may be due to lack of a surrounding procoagulant lipid matrix. The high concentrations of potentially active TF in plasma found in the present study suggest a possible physiological role for plasma TF, more specifically in situations where tissue injury may lead to exposure of procoagulant phospholipid.

\section{$>$ I MATERIALS AND METHODS}

\section{Materials}

Chromogenic factor $X$ substrate S-2765 was purchased from Chromogenix $A D$, Mölndal, Sweden. Triton $X-100$ (Triton) and polyoxyethylenesorbitan monolaurate (Tween 20) were from Sigma Chemical Company, St. Louis, MO, and n-octyl-B-D-glucopyranoside (glucoside) was from ICN Biomedicals Inc., Aurora, Ohio. The HRP substrate 3,3',5,5'-tetramethylbenzidine (TMB) was from Kirkegaard \& Perry Laboratories Inc., Gaithersburg, MD. Affigel-15 agarose for covalent coupling of proteins, with a chemical capacity of 15 $\mu \mathrm{mol} / \mathrm{mL}$ gel, was purchased from Bio-Rad Laboratories, Hercules, CA. Nuncimmuno plates, type Maxisorp, were from Nalge Nunc International, Rochester, NY. Slide-A-Lyzer dialysis cassettes and micro-BCA protein assay reagent kits for the measurement of total protein concentration, were from Pierce Chemical Company, Rockford, IL. Phospholipids, 1,2-dioleoyl-snglycero-3-phosphatidyl-serine and 1,2-dioleoyl-sn-glycero-3-phosphatidylcholine, were from Avanti Polar-Lipids Inc., Alabaster, AL, and were used in a mixture of $20 \mathrm{~mol} \% / 80 \mathrm{~mol} \%$ throughout the study. Ammonium thiocyanate was from Merck, Darmstadt, and urea from Serva, Heidelberg, Germany. All other chemicals used were of the highest grade available.

\section{Proteins}

Human recombinant TF in $0.01 \%$ 3-[(3-cholamidopropyl)dimethylammonio]-1-propanesulfonate (CHAPS) was from Calbiochem, San Diego, CA. This protein (calTF) was produced in SF9 insect cells using a baculovirus expression vector and had a molecular weight of 35-37 kD. Human 
recombinant soluble tissue factor (sTF, residues $1-219, M_{r}=26.8 \mathrm{kD}$ ) was produced in E.coli as described ${ }^{12}$. Monoclonal antibody AD 4503 (clone TF9. $10 \mathrm{H} 10)$ against an extracellular epitope of human TF was purchased from American Diagnostica Inc., Greenwich, CT, and has been characterized ${ }^{13}$. This monoclonal antibody shows a negligible effect on procoagulant activity. Highaffinity $\left(K_{d}=-10^{-11} \mathrm{M}\right)$, non-competing monoclonal antibodies CLB/TF-5 and non-inhibitory CLB/TF-1, raised against human recombinant soluble TF (Chiron Corp., Emeryville, CA), and poly-HRP conjugated streptavidin (enzyme/protein ratio 20) were obtained from Sanquin Research, Amsterdam, the Netherlands. Biotinylation of CLB/TF-1 antibody was performed with EZ Link Sulpho-NHS-LC biotin of Pierce in which a biotin:CLB/TF-1 ratio of 600:1 was used. Pure recombinant human factor Vlla, with a specific activity of 50 $\mathrm{kU} / \mathrm{mg}$, was from Novo Nordisk, Copenhagen, Denmark. It was verified that freshly reconstituted factor Vlla could be stored at $-80^{\circ} \mathrm{C}$ for at least 6 months, without significant loss of activity. Bovine factor $X$ was from Synapse BV, Maastricht, the Netherlands. Bovine serum albumin (BSA, purity $98-99 \%$, fatty acid-free) was from ICN Biomedicals Inc., Aurora, $\mathrm{OH}$, and chicken egg ovalbumin (A-5503, purity $>98 \%$ ) from Sigma-Aldrich, St. Louis, MO.

\section{Buffers}

Phosphate-buffered saline (PBS) contained $10 \mathrm{mM}$ PBS and $150 \mathrm{mM} \mathrm{NaCl}$, $\mathrm{pH}$ 7.4. PBST buffer was PBS buffer containing $0.2 \%$ (vol/vol) Tween-20. HEPES-buffered saline (HBS) contained $25 \mathrm{mM}$ HEPES (N-2hydroxyethylpiperazine- $\mathrm{N}^{\prime}$-2-ethanesulfonic acid) and $175 \mathrm{mM} \mathrm{NaCl}, \mathrm{pH} 7.7$. HBSA buffer was HBS buffer containing $0.5 \%$ (w/v) BSA. TBSA-EDTA buffer contained $50 \mathrm{mM}$ Tris (tris(hydroxymethyl)aminomethane), $175 \mathrm{mM} \mathrm{NaCl}, 20$ mM EDTA (ethylenediaminetetraacetic acid) and $0.05 \%(\mathrm{w} / \mathrm{v})$ chicken egg ovalbumin, $\mathrm{pH}$ 7.9. High performance ELISA buffer (HPE), designed to reduce background signal in ELISAs using biotin-(strept)avidin amplification, was from Sanquin Reagents, Amsterdam, the Netherlands.

\section{Plasma and serum from healthy donors}

After informed consent, venous blood samples were taken from 20 healthy donors of the Sanquin Bloodtransfusion Service, Maastricht, 11 men and 9 women and with a median age of 43 (15-64) years. Following routine donation of $500 \mathrm{~mL}$ blood, additional blood samples were collected in Vacutainer glass tubes containing either sodium citrate, sodium heparin or potassium EDTA. Plasma was obtained by centrifugation for $6 \mathrm{~min}$ at $2500 \mathrm{~g}$ at room temperature. Serum samples were collected after clotting by centrifugation for $12 \mathrm{~min}$ at $1850 \mathrm{~g}$. Samples were aliquoted and stored at $-80^{\circ} \mathrm{C}$. 


\section{Tissue factor activity assay}

The assay was adapted from Giesen et al. ". TF was extracted from plasma by antibody-coated Affigel-15. Next, TF was harvested from the beads, reconstituted into phospholipid-glucoside micelles, and its factor $X$ converting capacity in the presence of factor VIla was measured. Activity calibrator samples of full-length recombinant human TF underwent exactly the same procedures as the plasma samples, and by determination of its catalytic constant $k_{\text {cat }}$, allowed expression of activities in mol $/ L$ of active protein.

\section{Covalent coupling of TF antibody to the Affigel-15 matrix}

After washing Affigel-15 with cold deionized water, monoclonal TFantibody $(0.2 \mathrm{mg}$ of CLB/TF-1 per mL of gel) was coupled to Affigel-15 in 0.2 $M \mathrm{NaHCO}_{3}$ supplemented with $0.5 \mathrm{M} \mathrm{NaCl}$, $\mathrm{pH} 8.5$, by rotating the mixture end-over-end for $2 \mathrm{~h}$ at room temperature. Remaining active groups were blocked by the addition of $100 \mu \mathrm{L} 1 \mathrm{M}$ ethanolamine, $\mathrm{pH} 8.0$, and another hour of rotation. To remove excess uncoupled TF mAb and to ensure that no free antibody remained attached, the gel was washed 5 times with, alternatively, $0.5 \mathrm{M}$ ethanolamine supplemented with $0.5 \mathrm{M} \mathrm{NaCl}, \mathrm{pH} 8.3$, and $0.1 \mathrm{M}$ sodium acetate supplemented with $0.5 \mathrm{M} \mathrm{NaCl}, \mathrm{pH} 4.0$. Finally, the gel was equilibrated in $\mathrm{HBS}$ containing $0.2 \%$ sodium azide and stored at $4^{\circ} \mathrm{C}$.

\section{Extraction of TF from plasma samples and reconstitution of TF activity}

TF in plasma was solubilized by addition of Triton (1 vol\%), and samples of $1 \mathrm{~mL}$ were added to $100 \mu \mathrm{L}$ antibody-coated Affigel-15 in $2 \mathrm{~mL}$ reaction vials. After end-over-end rotation for 1 hour at room temperature, the gel was removed by centrifugation and washed 6 times with HBS. The bound protein was eluted in a $0.5 \mathrm{~mL} 100 \mathrm{mM}$ glycine- $\mathrm{HCl}$, pH 2.5, supplemented with 100 $\mathrm{mM} \mathrm{NaCl}, 25 \mathrm{mM}$ glucoside, $50 \mu \mathrm{M}$ phospholipids and HBSA for $30 \mathrm{~min}$. The gel was removed by centrifugation and the $\mathrm{pH}$ of the supernatant was neutralized

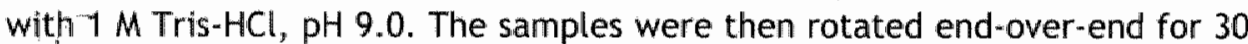
min at room temperature and diluted 5-fold in HBSA. TF-VIla activity was measured as described below. Use of lower $(0.1 \%)$ or higher $(2 \%)$ Triton concentrations did not influence the TF extraction from plasma (data not shown).

\section{Measurement of factor $X$ converting activity}

Activation of factor $X$ to factor $X a$ by TF-Vlla was performed in $1 \mathrm{~mL}$ reaction mixtures in $10 \times 10 \times 48 \mathrm{~mm}$ cuvettes. Samples were diluted in HBSA and were incubated for $7 \mathrm{~min}$ at $37^{\circ} \mathrm{C}$ with $1 \mathrm{nM}$ factor Vlla, $5 \mathrm{mM} \mathrm{CaCl}$ and 6 $\mu \mathrm{M}$ of sonicated phospholipid vesicles. Factor $\mathrm{X}$ activation was initiated by the addition of bovine factor $X(150 \mathrm{nM}$ final concentration). At $360 \mathrm{~s}$ intervals, a total number of four $50 \mu \mathrm{L}$-samples were taken and transferred to microtiter 
plate wells containing $100 \mu \mathrm{L}$ TBSA-EDTA, which terminated factor Xa production. Finally, factor Xa activity was measured by addition of $50 \mu \mathrm{L} \mathrm{S-}$ $2765(0.5 \mathrm{mM}$ final concentration) and monitoring the absorbance at $405 \mathrm{~nm}$ at $37^{\circ} \mathrm{C}$ on a kinetic ELISA plate reader. Intra- and inter-assay imprecision of a control plasma were $8.5 \%$ and $21.4 \%(n=8)$. The detection timit of the assay was $80 \mathrm{fM}(\mathrm{n}=10)$.

\section{Tissue factor activity calibrator}

Mixtures of phospholipids in chloroform at a final concentration of $2.5 \mathrm{mM}$ were dispensed in a glass tube and dried under a stream of nitrogen. Subsequently, $40 \mathrm{mM}$ of glucoside in HBS was added, and the mixture was vortexed in order to dissolve the phospholipids. The desired amount of calTF (typically $300 \mathrm{nM}$ ) was added and the solution was supplemented with HBSA to obtain a $1 \mathrm{~mL}$ volume. The samples were rotated end-over-end for $30 \mathrm{~min}$ at room temperature and equilibrated against working buffer by dialyzing for 1 hour against $1 \mathrm{~L} \mathrm{HBS}$, changing dialysis buffer after $30 \mathrm{~min}$.

Determination of TF antigen in this calibrator with the ELISA revealed that addition of Triton did not result in the detection of more TF, in contrast to samples that had been dialyzed for 3 days (data not shown). Therefore, we hypothesize that the TF in the calibrator was incorporated in phospholipidglucoside micelles, with all TF molecules facing outward and $100 \%$ available for binding by an antibody or factor Vila.

Activity calibrator samples containing $0,3,6$ and $12 \mathrm{pM}$ of active $\mathrm{TF}$ in buffer underwent the same extraction and reconstitution procedures as plasma or serum samples. Recoveries of this calibrator in buffer were linear up to at least $40 \mathrm{pM}$ and were also not influenced by lower $(0.1 \%)$ or higher (2\%) Triton concentrations (data not shown). A typical calibration curve is shown in Figure 1, right panel.

\section{Determination of $k_{\text {cat }}$ and $K_{d}$ of the activity calibrator}

The rate of factor $X a$ production $(v)$ was measured by titration of a fixed concentration of VIla with the activity calibrator, and vice versa. Using the program Solver of Microsoft Excel, values of $k_{\text {cat }}$ and $k_{d}$ were obtained by fitting the initial velocity data to the following equation: $v=0.5 \mathrm{k}_{\text {cat }}\left[\left(\mathrm{TF}_{0}+\right.\right.$ $\left.\left.V_{I I I}+K_{d}\right)-\sqrt{ }\left\{\left(T F_{0}+V I I a_{0}+K_{d}\right)^{2}-4 T F_{0} V I I a_{0}\right\}\right]$. The term between square brackets represents the concentration of TF-VIla complexes formed for total concentrations $T F_{0}$ and $V_{1 I a_{0}}$ and a dissociation constant $K_{d}$. It was verified that in the absence of TF the factor X-converting activity of factor Vila was negligible. 


\section{Tissue factor antigen assay (ELISA)}

Nunc immuno plates were coated overnight at $4^{\circ} \mathrm{C}$ with $100 \mu \mathrm{L}$ of $5 \mu \mathrm{g} / \mathrm{mL}$ capture antibody CLB/TF-5 in $100 \mathrm{mM}$ sodium carbonate, $\mathrm{pH}$ 9.6. Plasma was diluted 5 -fold in HPE buffer containing $1 \%$ (vol/vol) Triton, and $100 \mu$ L samples were incubated with $55 \mathrm{ng}$ of biotinylated CLB/TF-1 antibody, for $2 \mathrm{~h}$ at room temperature on a shaker. After washing 5 times with PBST, $100 \mu \mathrm{L}$ poly-HRP conjugated Streptavidin $(0.1 \mu \mathrm{g} / \mathrm{mL})$ was added and incubated for another 20 min. After washing again, $100 \mu \mathrm{L}$ of TMB substrate was added and after 15-20 min the reaction was stopped by the addition of sulfuric acid. The optical absorption at $450 \mathrm{~nm}$ was read on a Benchmark microplate reader (Bio-Rad Laboratories, Hercules, CA).

Both antibodies used in this ELISA were raised against STF and thus recognized the alternatively-spliced soluble TF variant (ashTF). Recombinant soluble TF was used as calibrator. To check its purity, $20 \mu \mathrm{g} / \mathrm{mL}$ of sTF (as determined with the total protein assay) in PBS was incubated with $0.5 \mathrm{~mL}$ CLB/TF1-coated Affigel-15 at room temperature. After 1 hour, 10\% of total protein content and $13 \%$ of TF antigen was found in the supernatant. Assuming a $K_{d}$ for binding of TF to CLB/TF-1 of approximately $10^{-11} \mathrm{M}$, as estimated at Sanquin Research, it is calculated that at equilibrium the bound fraction will be $89 \%$, in accordance with the $87-90 \%$ observed. It was concluded that the STF in the ELISA calibrator was $100 \%$ antigenic and, using a molecular mass of $28.6 \mathrm{kD}$ for $\mathrm{sTF}$, allowed expression of antigen concentrations in $\mathrm{mol} / \mathrm{L}$.

Recovery of plasma spiked with sTF was 100\% (data not shown). A typical calibration curve is shown in Figure 1 , left panel. Intra- and inter-assay imprecision of a control plasma were $2.6 \%$ and $13.3 \%(n=8)$. The detection limit, defined as $>99$ percentile of blank values, was $40 \mathrm{fM}(n=10)$.

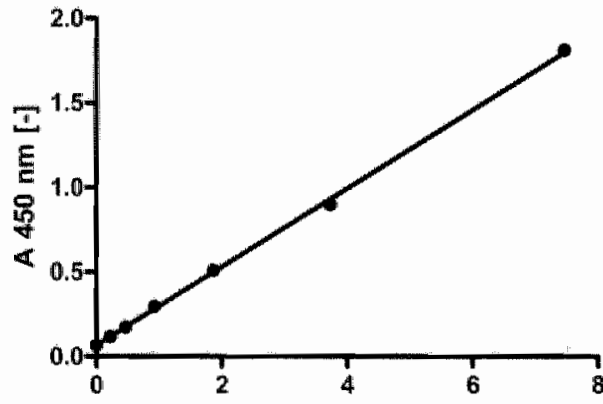

[TF] (pM)

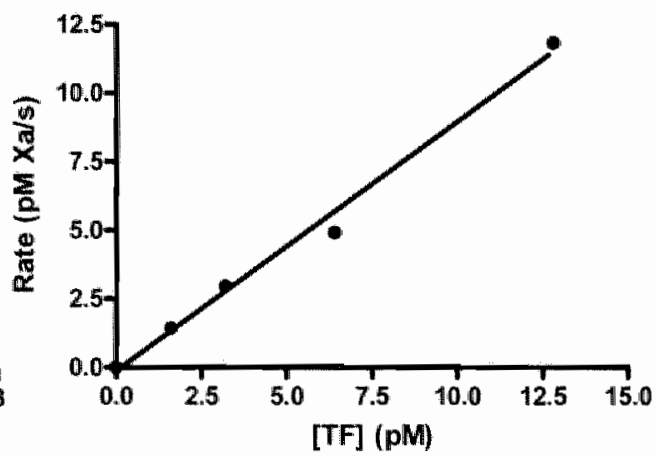

Figure 1. Calibration curves for determination of TF antigen and activity. Typical calibration curves for the TF ELISA, left panel, and the tissue factor activity assay, right panel. 


\section{Statistics}

Values are presented as mean \pm SD or, for non-Gaussian distributions, as medians with total range. The significance of differences was tested by using the Wilcoxon test for matched pairs (GraphPad Prism version 4.00 for Windows, GraphPad Software, San Diego, CA, USA).

\section{RESULTS}

\section{Catalytic constants and concentration of active protein in the activity calibrator}

Initial rates of factor Xa production were measured when $1 \mathrm{pM}$ factor VIlla was titrated with the activity calibrator (Fig. 2, left panel). By fitting these velocity data into the equation presented in Methods, values of $k_{\text {cat }}=1.9 \pm 0.2$ $\mathrm{s}^{-1}$, and apparent $K_{d}=29 \pm 10 \mathrm{pM}(\mathrm{n}=3)$ were obtained. Subsequently, $20 \mathrm{pM}$ (according to the manufacturer) of the calibrator was titrated with factor VIla (Fig. 2, right panel). Using the obtained $k_{\text {cat }}$ value, the percentage of active TF in the calibrator was estimated at $15.3 \pm 0.8 \%$. This also changed the apparent $K_{d}$ value to a true $K_{d}$ of $3.9 \pm 1.7 \mathrm{pM}$, close to the value of $3.7 \pm 0.4 \mathrm{pM}$ obtained from the right panel experiment. Using values of $26.8 \mathrm{kD}$ and $36 \mathrm{kD}$ for the molecular masses of sTF and calTF, respectively, only $11.3 \pm 0.2 \%$ (mean $\pm \mathrm{SD} ; \mathrm{n}=12$ ) of the indicated TF concentration was found to be antigenic in the ELISA, confirming that only a fraction of this preparation consisted of intact TF. Therefore the concentration of active TF in the activity calibrator was assumed to be $15.3 \%$ of the indicated calTF content.
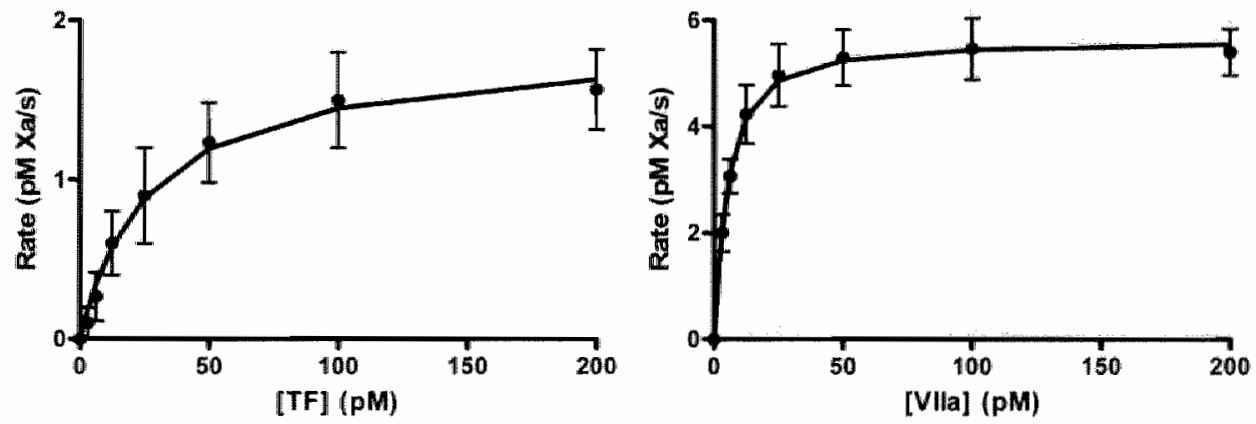

Figure 2. Assessment of catalytic constants for factor $\mathrm{X}$ activation by TF-Vlla. left panel, increasing concentrations of TF were incubated with $1 \mathrm{pM} \mathrm{Vlla}, 5 \mathrm{mM} \mathrm{CaCl}$ and $6 \mu \mathrm{M}$ phosphotipids. Right panel, increasing concentrations of Vlla were incubated with $20 \mathrm{pMTF}, 5 \mathrm{mM} \mathrm{CaCl}$ and $6 \mu \mathrm{M}$ phospholipids. Factor $\mathrm{Xa}_{\mathrm{a}}$ activation was initiated by addition of $150 \mathrm{nM}$ factor $X$. Yalues of $k_{\text {eat }}=1.9 \pm 0.2 \mathrm{~s}^{\| 1}$ and $K_{\mathrm{d}}=3.7 \pm 0.4 \mathrm{pM}$ were obtained. 


\section{Extraction of the activity calibrator from buffer and plasma}

After $1 \mathrm{~h}$ extraction of the activity calibrator from HBSA buffer by CLB/TF. 1 coated Affigel-15 in 1\% Triton, the percentage of extracted TF antigen determined by ELISA was $88.2 \pm 8.1 \%(n=30)$. The percentages of extracted TF antigen from healthy donor plasma were $78.4 \pm 9.6 \%$ for citrated plasma, 74.7 $\pm 11.1 \%$ for EDTA plasma, $72.4 \pm 12.0 \%$ for heparinized plasma, and $68.6 \pm$ $15.6 \%$ for serum (mean $\pm S D, n=19$ ). These extractions could not be quantified on basis of TF activity, because Triton inhibited the activity assay.

\section{Recovery of the activity calibrator from buffer and plasma}

After elution with glycine- $\mathrm{HCl}$ and neutralisation, the recoveries of the activity calibrator from HBSA buffer (in the presence of $1 \%$ Triton) were $23.6 \pm$ $4.3 \%(n=14)$ for CLB/TF-1 coated Affigel-15. Apparently, the use of this highaffinity antibody prevented the elution of a large fraction of bound TF. Recoveries (mean \pm SD) of the calibrator from plasma were $6.1 \pm 0.2 \%, 9.7 \pm$ $1.9 \%$, and $18.4 \pm 2.2 \%$ for $0 \%, 0.1 \%$ and $1 \%$ Triton, respectively.

\section{Absence of activity of plasma TF in its in situ plasma matrix}

Since the CLB/TF-1 antibody was non-inhibitory for TF, plasma TF activity was determined with the TF molecules still bound to the beads in their in vivo proteo-lipid matrix. TF was captured from plasma by CLB/TF-1 coated Affigel15, without detergent, and non-bound plasma proteins were washed away with HBS. TF activity was then measured, with subsamples taken from endover-end rotating tubes, in order to prevent sedimentation of the Affigel. No TF activity was found. Similar experiments with the activity calibrator in HBSA buffer produced recoveries of $52 \pm 8 \%(n=6)$. Thus, although TF activity in micelles bound to the Affigel beads appeared to be partially inhibited, possibly due to sterical hindrance or diffusion limitation, its activity could still be easily detected. In another attempt to estimate TF activity in its in vivo matrix, we performed the TF capture activity assay without Triton and eluted TF without glucoside and phospholipids. Again, no TF activity was found in plasma, whereas the recovery of the calibrator from HBSA buffer under these circumstances was $28 \pm 2 \%(n=4)$. The results are summarized in Figure 3 .

\section{Further characterization and attempts at optimization of the TF activity assay}

As summarized in Figure 4, effects of several modifications on the TF activity assay were investigated.

Introduction of a dialysis step

The high critical micelle concentration of glucoside $(20-25 \mathrm{mM})$ enables its rapid removal by dialysis. Therefore, the effect of short dialysis periods of the 
TF-glucoside-phospholipid micelles obtained after elution was verified. Eluates were dialysed in Slide-A-Lyzer dialysis cassettes against HBS for $0.5,1$ or $1.5 \mathrm{~h}$ at $4^{\circ} \mathrm{C}$, refreshing dialysis buffer every $30 \mathrm{~min}$. However, dialysis did not improve activity or recovery and a mean recovery of $22.8 \pm 3.8 \%(n=6)$ was found.

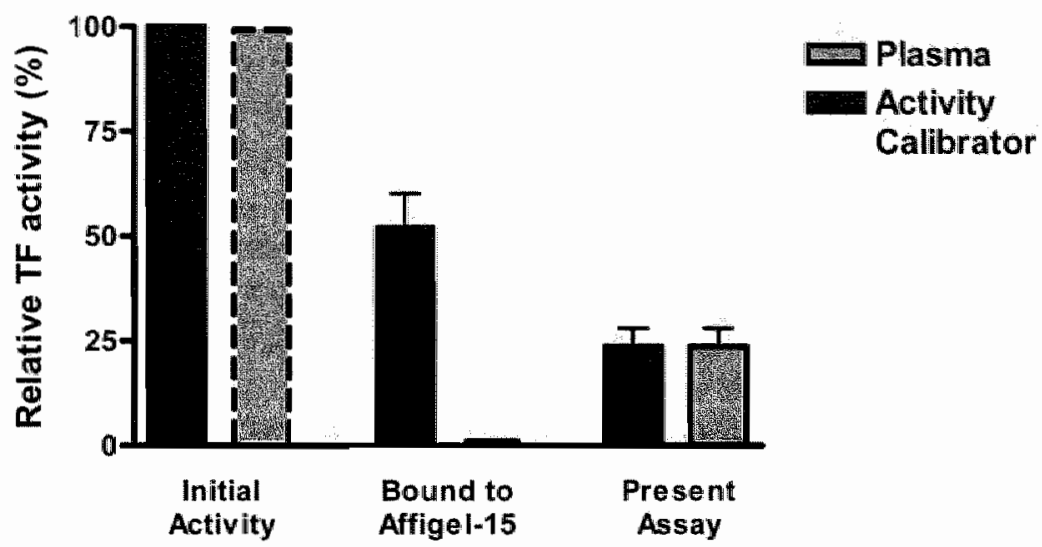

Figure 3. TF activity in its original proteo-lipid environment. TF actiwities of plasma and activity calibrator were measured in the TF activity assay. Imitial TF activity of the activity calibrator and plasma were set at 100\%. Note that initial TF actiwity in plasma could not be measured, and that no activity was found for" plasma TF bound to Affigel-15.

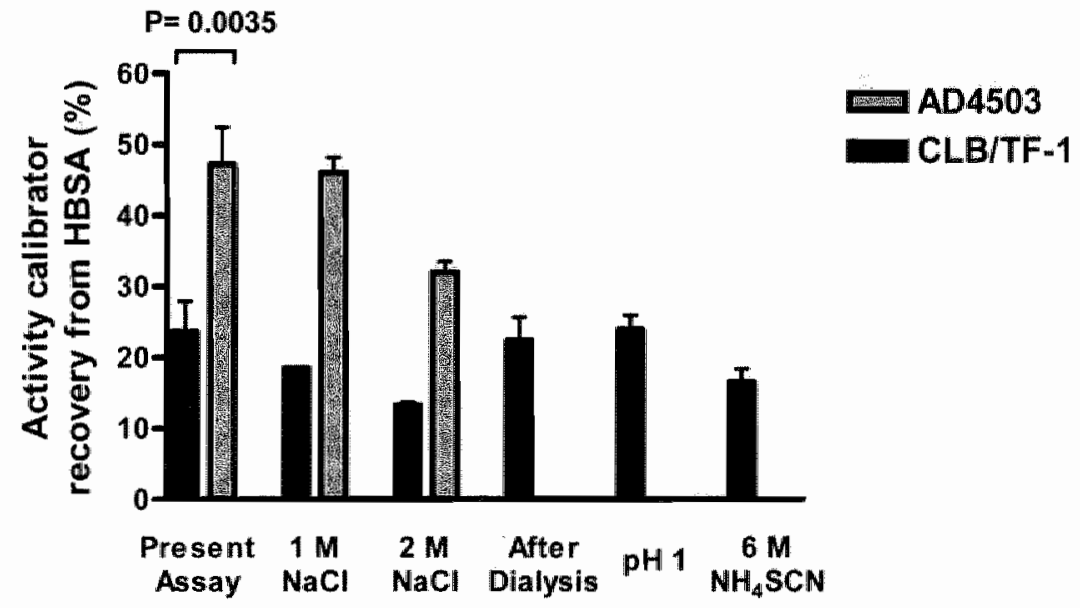

Figure 4. Recovery of the TF activity calibrator from buffer. Samples were added to CLB/TF.1 coated Affigel-15 and incubated for 1 hour at room temperature. Bound TF was eluted as indicated. TF activities in the reconstituted samples were compared with TF activities in the original samples. 
Use of a capture antibody with lower affinity

Since the CLB/TF-1 antibody was selected for its high affinity, the recovery after elution might improve by using a lower-affinity antibody. Using a commercially available antibody, $A D 4503$, this was tested and higher recoveries from buffer, $47.2 \pm 5.2 \%(n=4)$, were indeed obtained (Fig. 4). Because plasma samples and calibrator showed similarly increased recoveries, however, net results were nihil. To maintain comparability, the CLB/TF-1 antibody used in the ELISA was also used in the activity assay.

\section{Modification of the elution procedure}

in attempts to improve the recovery after extraction, elution at $\mathrm{pH} 1.0$ and the influence of elution time $(1,5,10,20$ and $30 \mathrm{~min})$ on the release of TF from the Affigel matrix were studied. No effects were found (mean recovery: $24 \pm 2 \% ; n=10)$. The combination of acid $(\mathrm{pH} 1.0)$ and high-salt elution also did not improve recovery: for CLB/TF-1 the recoveries were 18.5 $\pm 0.1 \%$ and $13.3 \pm 0.6 \%$ for $1 \mathrm{M}$ and $2 \mathrm{M} \mathrm{NaCl}$, respectively, and for the AD4503 antibody these figures were $46 \pm 2 \%$ and $32 \pm 1.5 \%(n=2)$. Chaotropic elution with $6 \mathrm{M}$ ammonium thiocyanate, instead of acid solution, was tested for various elution times (up to $30 \mathrm{~min}$ ), but no effects on mean recovery (17 $\pm 2 \%) ; n=8$ ) were found. In spite of the incomplete recovery of TF activity from the Affigel beads, intra- and inter-assay imprecision of a control plasma remained within an acceptable range of $9 \%$ and $21 \%(n=8)$, respectively.

Attempts at regeneration of antibody-coated Affigel-15 with urea

CLB/TF-1-coated and AD4503-coated Affigel-15 were incubated for three consecutive periods of $30 \mathrm{~min}$ with excess activity calibrator. Then the gell was exposed twice to $8 \mathrm{M}$ urea for $30 \mathrm{~min}$. Finally, after washing away urea with HBS, we studied the capture ability of the 'regenerated' gel by analyzing the remaining TF activity in the supernatant after a $1 \mathrm{~h}$ incubation with $12 \mathrm{pM}$ calibrator. Values of $11 \pm 6 \%(n=2)$ and $13 \pm 8 \%(n=2)$ were obtained for the extraction by CLB/TF-1 and AD4503, respectively. This poor extraction was not caused by denaturation of the antibodies because, after exposure of nonused CLB/TF-1 coated Affigel-15 to $8 \mathrm{M}$ urea for up to $40 \mathrm{~min}$, extraction of activity calibrator remained $75 \pm 9 \%(n=8)$.

\section{TF antigen and activity levels in plasma from healthy donors}

One donor showed outlying values of $50 \mathrm{pM}, 226 \mathrm{pM}, 237 \mathrm{pM}$ and $177 \mathrm{pM}$ for TF antigen in citrate, EDTA, heparin plasma and serum, respectively. Similar TF antigen levels were found in this donor's plasma after extraction of TF in the first step of the TF activity assay. In contrast, normal values of 1.3 PM and $2.0 \mathrm{pM}$ were found for TF activity in citrated and EDTA plasma, respectively. In addition, this patient's plasma showed equally outlying values 
in an ELISA for fatty acid-binding protein that, like the TF ELISA, employs murine antibodies but not in an ELISA for prothrombin fragment $1+2(F I+2)$ that employs rabbit antibodies (data not shown). Therefore, it was concluded that the plasma probably contained anti-mouse IgG antibodies, and this donor was excluded from further analysis.

Figure 5 presents the results for the measurements of TF antigen and TF activity in citrated plasma from the remaining 19 healthy donors. Median TF antigen levels with total ranges were $2.5(1.0-9.3) \mathrm{pM}, 3.4(2.2-17.6) \mathrm{pM}$ and 3.4 (2.4-19.2) $\mathrm{pM}$ for citrated, EDTA and heparinized plasma, respectively, and $2.8(1.3-9.8) \mathrm{pM}$ for serum. Pearson correlation coefficients were 0.92 for citrate vs. heparine, 0.93 for citrate vs EDTA, 0.90 for citrate vs serum, 0.96 for heparine vs EDTA, 0.89 for heparine vs serum and 0.87 for EDTA vs serum.

Median TF activity levels with total ranges were $2.0(1.3-4.2) \mathrm{pM}$ and 2.3 (1.3-5.3) $\mathrm{PM}$ for citrated and EDTA plasma, respectively, and the Pearson correlation coefficient was 0.85 . Surprisingly, however, no TF activity was found in heparinized plasma or serum. The differences between TF antigen and TF activity were statistically significant $(p=0.005)$ for EDTA plasma, but not for citrated plasma.

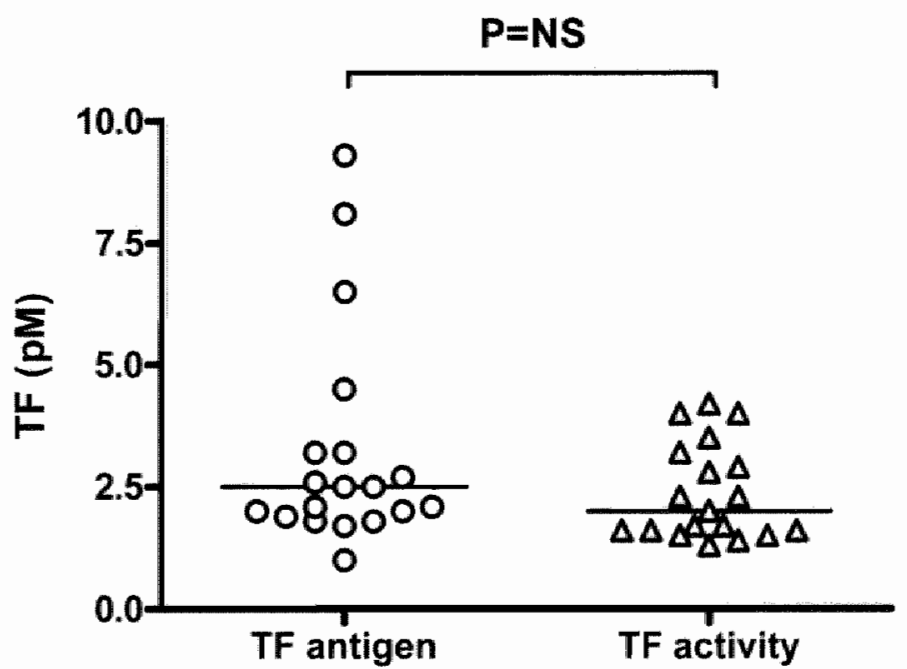

Figure 5. TF antigen and TF activity in citrated plasma from healthy donors. No significant difference between TF antigen and TF activity was found. 


\section{$>$ DISCUSSION}

The present study describes a new capture assay for TF activity in plasma. Plasma TF proved to be totally inactive when in its in vivo matrix, but activity could be restored by elution and incorporation of TF into phospholipidglucoside micelles. This reactivation protocol produced a rapid assay without the need for a dialysis step, which could be of more general importance for membrane protein assays. Measurement of the catalytic constant $k_{\text {cat }}$ of the full-length human TF calibrator used in this assay allowed the expression of measured activities in mol/L of active protein. In addition, a new ELISA for TF antigen in human plasma was developed, with a detection limit of $40 \mathrm{fM}$, about 6 times lower than has been reported for existing assays.

\section{Effects of anticoagulants}

Approximately similar concentrations of TF antigen and TF activity were found in citrated and EDTA plasma, with antigen concentrations 20-30\% higher than activity concentrations, although the difference was not significant for citrated plasma.

ELISA measurements clearly indicated the presence of TF antigen in heparinized plasma and serum, but we did not detect TF activity in these samples. Nonetheless, the TF antigen could easily be depleted from plasma by the first step of the capture assay, indicating that the antibody recognized TF in these media. While the anticoagulant action of EDTA and sodium citrate is based on chelation of calcium-ions, heparin enhances the anticoagulant action of antithrombin III and tissue factor pathway inhibitor (TFPI). Therefore, we hypothesize that formation of TF-VIIa-Xa-TFPI complexes in heparinized plasma and serum may inhibit TF-activity, while not preventing the recognition of TF by its (non-inhibitory) antibodies.

\section{Comparison with plasma TF antigen concentrations reported in the literature}

Using a variety of laboratory and commercial ELISAs, the average plasma TF antigen concentrations as reported for citrated plasma of healthy controls are in the range of $125-175 \mathrm{pg} / \mathrm{mL}^{14-17}$. The median value with range of 2.5 (1.0-9.3) $\mathrm{pM}$, as found in the present study for TF antigen in citrated plasma, corresponded to a mean value of $3.2 \pm 2.3 \mathrm{pM}$ (mean $\pm \mathrm{SD}$ ) or, using a molecular weight of $47 \mathrm{kD}$ for glycosylated full-length human TF, $150 \pm 108$ $\mathrm{pg} / \mathrm{ml}$, in agreement with these earlier results. Apparently, the various antibodies used in these studies detected the same amount of protein. 


\section{Comparison with plasma TF activity measurements from the literature}

Measurements of TF activity in plasma or whole blood may be influenced by contact activation or by strong feedback mechanisms, such as inactivation of TF-VIla by TFPI, its endogenous inhibitor. As a result, only few attempts at such measurement have been made ${ }^{6,18,19}$ and, with the exception of the study by Giesen et al. ${ }^{6}$, results were expressed in arbitrary units. The relatively low value of $17 \pm 7 \mathrm{pg} / \mathrm{ml}$ reported for plasma TF activity in the latter study is explained by omission of the correction for non-eluted activity and the rather high value of $k_{\text {cat }}=5 \mathrm{~s}^{-1}$ used in that study to calculate the TF concentration from the rate of factor Xa production.

\section{The origin of plasma TF}

The bulk of plasma TF is assumed to originate from blood cells. Microparticles in blood collected from the pericardial cavity of patients on cardio-pulmonary bypass did trigger thrombin formation via the TF-pathway and were found to originate from platelets, monocytes, erythrocytes, granulocytes and unknown other cellular sources ${ }^{8}$. It is also known from both in vivo and in vitro studies that TF mRNA can be detected in monocytes within minutes after stimulation with LPS ${ }^{20}$. Recently, Muller et al. ${ }^{21}$ also found TF to be stored in the a-granulae and the open canalicular system of blood platelets, while platelet activation may lead to shedding of TF-bearing microparticles 22 .

\section{Lack of in vivo activity of plasma TF}

Muller et al. ${ }^{21}$ found no TF activity in plasma of healthy donors, which is in agreement with the fact that we did not detect any activity for TF still bound to the Affigel beads in its in vivo matrix. A similar conclusion was reached by Berckmans et al. ${ }^{23}$ who found that thrombin generation in healthy donor plasma was independent of TF, even though the plasma contained TF. bearing microparticles. However, these results are in contrast with findings by Bauer et al. ${ }^{24}$, who detected activation peptides of IX, X and prothrombin $(F 1+2)$ in healthy donor plasma. These levels were decreased in patients with hereditary factor VII deficiency, but not in patients with factor XI deficiency, indicating TF-dependent thrombin formation.

An explanation for the absence, or limitation, of TF-dependent thrombin generation in normal plasma could be that only trace amounts of procoagulant PS are found in plasma of healthy controls ${ }^{25}$. This is also suggested by the fact that complete recovery from plasma of the activity calibrator, that is, TF in a procoagulant lipid matrix, did require the addition of detergent. It seemed as if procoagulant lipid, probably the presence of PS, will cause adsorption of plasma constituents that may partly shield TF from the capture antibody. Inflammatory stimuli, including stimulation with LPS, and platelet activation 
are known to cause exposure of PS, normally confined to the inner cellular membranes ${ }^{26}$. Because the assays may also be used for such patients, we routinely used $1 \%$ Triton. Together these findings suggest that the lack of exposed PS is probably the most important factor responsible for the absence of significant in vivo TF activity in plasma of healthy donors.

\section{$>$ CONCLUSIONS}

The present study demonstrates that most of a large pool of 2-3 pM of plasma TF antigen in healthy donors consists of potentially active protein and could potentially cause rapid clotting. It has been shown, for instance, that $0.5 \mathrm{pM}$ of active TF-phospholipid caused clotting of control plasma within 3 minutes ${ }^{3}$. We also show, however, that this procoagulant mechanism is absent in healthy donors, probably due to the lack of PS exposure. Procoagulant PS may become exposed, however, during inflammation or after tissue injury and the circulating plasma pool of potentially active TF could then play a physiological role in hemostasis as has recently been suggested $7,10,20$.

\section{$>$ ACKNOWLEDGEMENTS}

The authors wish to acknowledge valuable suggestions by $\mathrm{Dr}$. Theo Lindhout. Also, we would like to thank Mr. René van Derle and Dr. Rob Wagenvoord for providing recombinant factor VIla and purified bovine factor $X$, respectively, Ms. Hanny Klaasse Bos for the purification of the CLB/TF antibodies, and Dick van Hout and Steven Saers for their technical assistance and discussions. Jan FC Glatz is Netherlands Heart Foundation Professor. Research grants 98.063 and 2002B189 from the Netherlands Heart Foundation are also gratefully acknowledged. 
1. Nemerson Y. Tissue factor: then and now. Thromb Haemost. 1995;74:180-4

2. Morrissey $\mathrm{JH}$. Tissue factor modulation of factor Vlla activity: use in measuring trace levels of factor Vlla in plasma. Thromb Haemost. 1995;74:185-8.

3. Hemker $H C$, Giesen $P$, Al Dierí $R$, Regnault $V$, de Smedt $E$, Wagenvoord $R$, Lecompte $T$, Beguin $S$. Calibrated automated thrombin generation measurement in clotting plasma. Pathophysiol Haemost Thromb. 2003;33:4-15.

4. Bogdanov VY, Balasubramania $V$, Hathcock $J$, Vele $O$, Lieb $M$, Nemerson $Y$. Alternatively spliced human tissue factor: a circulating, soluble, thrombogenic protein. Nat Med. 2003;9:458-462.

5. Waxman E, Ross JBA, Laue TM, Guha A, Thiruvikraman SV, Lin TC, Koningsberg $W H$, Nemerson $Y$. Tissue factor and its extracellular soluble domain: The relationship between intermolecular association with factor VIla and enzymatic activity of the complex. Biochemistry. 1992;31:3998-4003.

6. Giesen PL, Rauch U, Bohrmann B, Kling D, Roqué M, Fallon JT, Badimon $\mathrm{J} J$, Himber J, Riederer MA, Nemerson Y. Blood-borne tissue factor: another view of thrombosis. Prac Natl Acad Sci U S A. 1999;96:2311-5.

7. Giesen PL, Nemerson Y. Tissue factor on the loose. Semin Thromb Hernost. 2000;26:379-84.

8. Nieuwland R, Berckmans RJ, Rotteveel-Eijkman RC, Maquelin KN, Roozendaal KJ, Jansen PGM, ten Have K, Eijsman L, Hack CE, Sturk A. Cell-derived microparticles generated in patients during cardiopulmonary bypass are highly procoagulant. Circulation. 1997; 96:3534-41.

9. Chou J, Mackman N, Merill-Skoloff G, Pedersen B, Firie BC, Furie B. Hematopoietic cell-derived microparticle tissue factor contributes to fibrin formation during thrombus propagation. Blood. 2004;104:3190-7.

10. Day $S M$, Reeve JL, Pedersen $B$, Farris DM, Myers DD, Im M, Wakefield TW, Mackman N, Fay WP. Macrovascular thrombosis is driven by tissue factor derived primarily from the blood vessel wall. Blood, 2005;105:192-8.

11. Sambola A, Osende J, Hathcock J, Degen $M$, Nemerson $Y$, Fuster $V$, Crandall J, Badimon JJ. Role of risk factors in the modulation of tissue factor activity and blood thrombogenicity. Circulation. 2003;107:973-7.

12. Rezaie AR, Fiore MM, Neuenschwander PF, Esmon CT, Morrissey JH. Expression and purification of a soluble tissue factor fusion protein with an epitope for an unusual calcium-dependent antibody. Protein Expr Purif. 1992;3:453-60.

13. Morrissey $\mathrm{JH}$, Fair DS, Edgington TS. Monoclonal antibody analysis of purified and cell-associated tissue factor. Thromb Res. 1988;52:247-6.

14. Albrecht $S$, Kotzsch $M$, Siegert $G$, Luther T, Grossmann H, Grosser M, Muller $M$. Detection of circulating tissue factor and factor $\mathrm{VII}$ in a normal population. Thromb Haemost. 1996;75:772-7. 


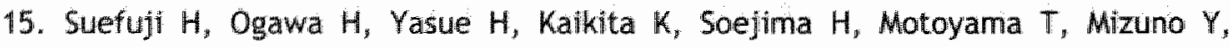

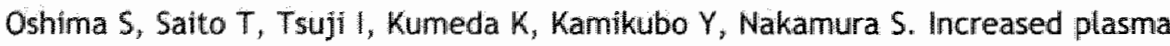
tïssue factor levels in acute myocardial infarction. Am Heart $J$. 1997;134(2 Pt 1):253-9.

16. Falciani $M$, Gori AM, Fedi S, Chiarugi L, Simonetti I, Dabizzi RP, Prisco D, Pepe G, Abbate R, Gensini GF, Neri Serneri GG. Elevated tissue factor and tissue factor pathway inhibitor circulating levels in ischaemic heart disease patients. Thromb Haemost. 1998; 79:495-9.

17. Malý M, Vojacek J, Hrabos V, Kvasnicka J, Salaj P, Durdil V. Tissue factor, tissue factor pathway inhibitor and cytoadhesive molecules in patients with an acute coronary syndrome. Physiol Res. 2003;52:719-28.

18. Wielders S, Mukherjee $M$, Michiels J, Rijkers DT, Cambus JP, Knebel RW, Kakkar $V$, Hemker $H C$, Beguin $S$. The routine determination of the endogenous thrombin potential, first results in different forms of hyper- and hypocoagulability. Thromb Haemost. 1997;77:629-36.

19. Tutar E, Ozcan $M_{\Perp}$ Kilickap $M$, Gulec $S$, Aras $O$, Pamir G, Oral D, Dandelet L, Key NS.

Elevated whole-blood tissue factor procoagulant activity as a marker of restenosis after percutaneous transluminal coronary angioplasty and stent implantation. Circulation. 2003;108(13):1581-4.

20. Engelmann B, Luther T, Muller I. Intravascular tissue factor pathway = a model for rapid initiation of coagulation within the blood vessel. Thromb Haemost. $2003 ; 89(1): 3-8$.

21. Muller I, Klocke A, Alex $M$, Kotzsch $M$, Luther $T$, Morgenstern $E$, Zieseniss $S$, Zahler $S$, Preissner $K$, Engelmann $B$. Intravascular tissue factor initiates coagulation via circulating microvesicles and platelets. Faseb $J_{*}$ 2003; 17:476-8.

22. VanWijk MJ, VanBavel E, Sturk A, Nieuwland R. Microparticles in cardiovascular diseases. Cardiovasc Res. 2003;59:277-87.

23. Berckmans RJ, Nieuwland R, Boing AN, Romijn FP, Hack CE, Sturk A. Cell-derived microparticles circulate in healthy humans and support low grade thrombin generation. Thromb Haemost. 2001;85(4):639-46.

24. Bauer KA, Kass BL, ten Cate H, Bednarek MA, Hawiger JJ, Rosenberg RD. Detection of factor $X$ activation in humans. Blood. 1989;74(6):2007-15.

25. Deguchi $H$, Fernandez JA, Hackeng TM, Banka $C L$, Griffin JH. Cardiolipin is a normal component of human plasma lipoproteins. Proc Natl Acad Sci U $S$ A. $2000 ; 97(4): 1743-8$.

26. Sims PJ, Wiedmer T. Unraveling the mysteries of phospholipid scrambling. Thromb Haemost. 2001;86(1):266-75. 



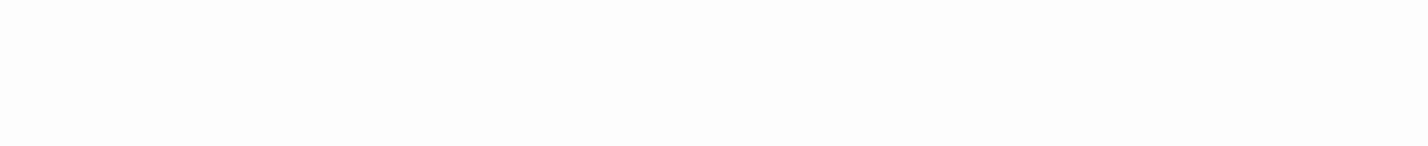




\section{CHAPTER 5}

FATTY ACID-BINDING PROTEIN AS AN EARLY PLASMA MARKER OF MYOCARDIAL ISCHEMIA AND RISK STRATIFICATION

JFC Glatz, RFM van der Putten, WT Hermens

Cardiovascular Research Institute Maastricht (CARIM), Maastricht University, Maastricht, the Netherlands

Published in: Cardiac Markers, Second Edition, edited by Alan H.B. Wu, Humana Press Inc., Totowa NJ, 2003, pp. 319-37 
ह
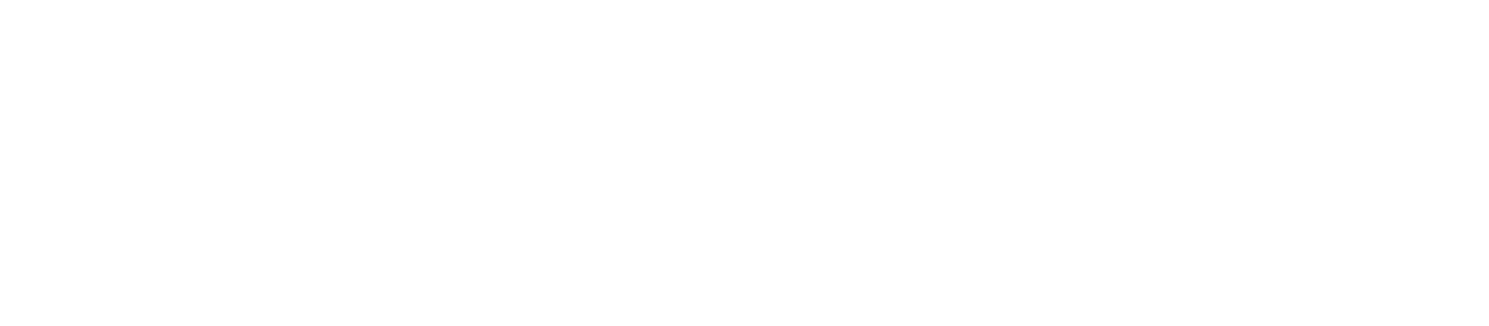

.
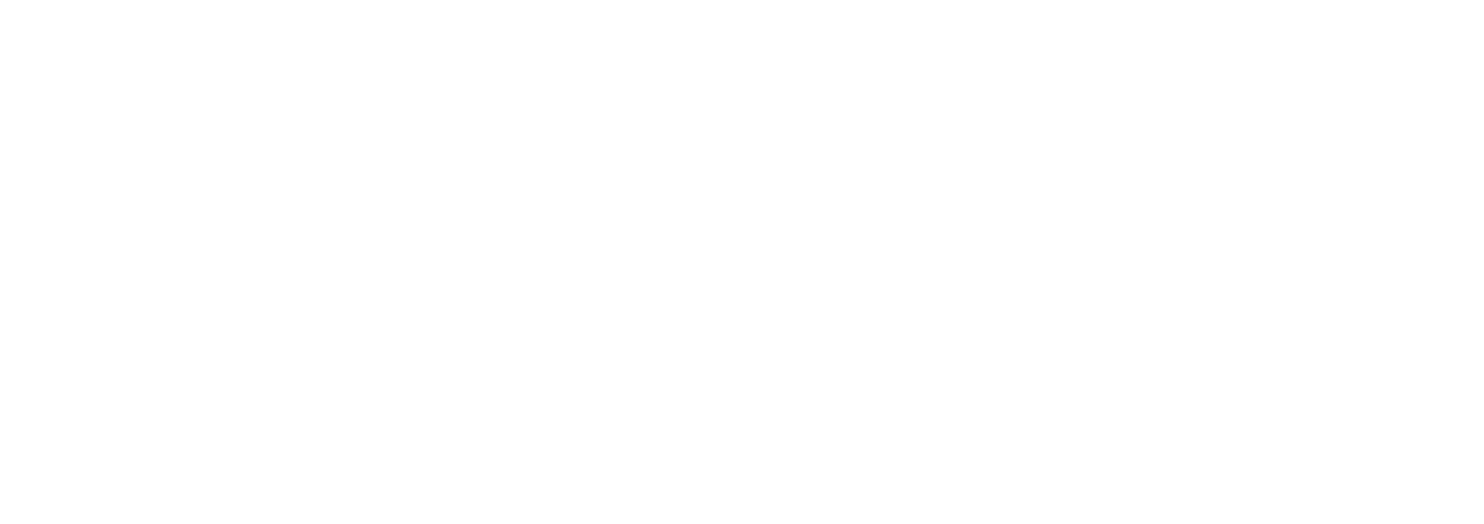
Biochemical markers of myocardial injury are universally accepted as important determinants for the diagnosis of patients with suspected acute myocardial infarction (AMI), especially in those cases in which electrocardiographic (ECG) changes are unequivocal or absent ${ }^{1,2}$. In the last decade, interest in these biochemical markers has increased for two reasons. First, the introduction of new therapeutic strategies has called for earlier and more appropriate diagnosis of patients admitted to the emergency room with chest pain, so as to begin the proper therapy as early as possible. Second, several new plasma markers have been introduced, and some (e.g., troponin $T$ (TnT)) allow for the assessment of patients with not only AMI but also unstable angina and prolonged chest pains, and even provide prognostic value ${ }^{3}$.

Fatty acid-binding protein (FABP) has similarly been proposed as an early plasma marker of acute coronary syndromes. In this chapter some relevant features of this protein are described and the studies that have investigated its application as marker of myocardial injury are summarized. The release and plasma kinetics of FABP closely resemble those of myoglobin, but the relatively low plasma reference concentration of FABP makes it superior to myoglobin for the monitoring of myocardial injury.

\section{BIOCHEMISTRY AND BIOLOGICAL FUNCTION OF FABP}

In the soluble cytoplasm of almost all tissue cells, a relatively small (14-15 $\mathrm{kD})$ protein is found that can reversibly and non-covalently bind long-chain fatty acids, and is therefore called (cytoplasmic) FABP. At least nine distinct types of FABP occur, and these are generally named after the tissue in which they were first identified and/or mainly occur, e.g., $H$ (heart)-FABP, L(liver)FABP, I(intestinal)-FABP. Subsequent studies revealed the presence of L-FABP also in small intestine, and that of H-FABP also in skeletal muscle, in distal tubule cells of the kidney, and in some parts of the brain ${ }^{4}$. The FABPs are relatively abundant in tissues with an active fatty acid metabolism, such as liver, adipose tissue, and heart, which each show a tissue content of $0.5-1 \mathrm{mg}$ FABP per $g$ wet weight of tissue ${ }^{4}$.

The FABPs belong to a multigene family of intracellular lipid-binding proteins, that also includes the cellular retinoid-binding proteins ${ }^{4,5}$. These proteins each contain 126-137 amino acid residues (molecular mass 14-15 kD) and show a similar tertiary structure which resembles that of a clam shell ${ }^{5}$ (Fig. 1). The lipid ligand is bound in between the two halves of the clam by interaction with specific amino acid residues within the binding pocket, a so- 
called B-barrel, of the protein. Human H-FABP contains 132 amino acid residues $(14.5 \mathrm{kD})$, and is an acidic protein (pl 5) ${ }^{6,7}$.

The FABPs appear to be stable proteins, exhibiting an intracellular turnover with a half-life of approximately $2-3$ days ${ }^{4}$. Their cellular expression is regulated primarily at the transcriptional level. In general, the FABP expression is responsive to changes in lipid metabolic activity as induced by various (patho-)physiological and pharmacological stimuli ${ }^{4}$. For instance, the $(\mathrm{H} \cdot)$ FABP content of heart and skeletal muscles increases by endurance training ${ }^{8}$, and is also higher in the diabetic state ${ }^{9}$ but is slightly decreased in the hypertrophied heart ${ }^{10,11}$.

The primary biological function of the FABPs is their facilitation of the cytoplasmic translocation of long-chain fatty acids, which is normally hampered by the very low solubility of these compounds in aqueous solutions 12. Therefore, FABP can be regarded as an intracellular counterpart of plasma albumin. Definite proof of this function was obtained recently, when it was found that cardiac myocytes isolated from mice lacking the H-FABP gene showed a markedly lower (approximately $-50 \%$ ) rate of fatty acid uptake and oxidation ${ }^{13}$. Other postulated functions for H-FABP and other types of FABP include a participation in signal transduction pathways such as fatty acid regulation of gene expression ${ }^{14,15}$, and the protection of myocytes against the adverse (detergent-like) effects of long-chain fatty acids ${ }^{4}$.

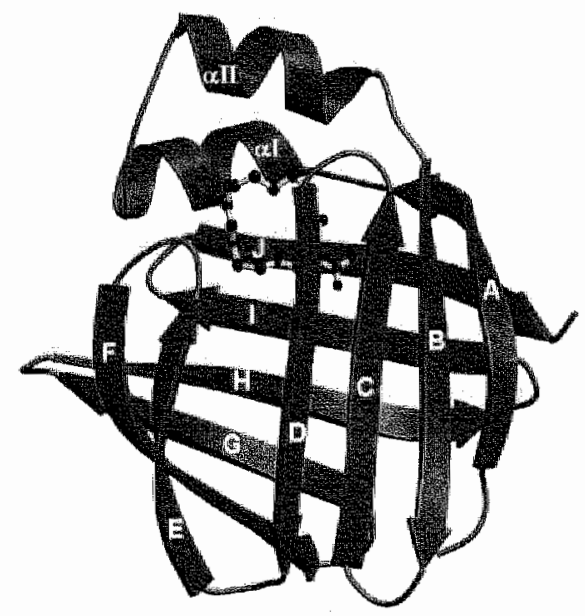

Figure 1. A schernatic view of fatty acid-binding protein (FABP) with bound long-chain fatty acid. A ribbon diagram is shown for human H(heart-type)- $F A B P$, highlighting two short a-helical domains (al and all), and $10 \mathrm{~B}$ strands ( $B A-B J)$ forming two so-called $B$-sheets in between which the fatty acid ligand (in this case, oleate) is bound in a U-shaped conformation. (Figure created using data from References 6 and 7 . Courtesy of dr. C. Lücke, Frankfurt, Gemany.) 
The latter function would be of special importance for the ischemic heart because the tissue accumulation of fatty acids and their derivatives occurring in this condition has been associated with arrhythmias, increased myocardial infarct size, and depressed myocardial contractility ${ }^{16}$. The presence of $\mathrm{H}$. FABP then may be crucial to sequester accumulating fatty acids and thus prevent tissue injury. However, currently available evidence for such a role for $\mathrm{H}$-FABP remains inconclusive ${ }^{4}$.

\section{IMMUNOCHEMICAL ASSAY OF FABP IN PLASMA}

Because FABP is a non-enzymatic protein, its detection and quantification must be performed with an immunochemical assay. A large number of immunoassays for H-FABP have been described, mostly enzyme-linked immunosorbent assays (ELISAs) of the antigen capture type ${ }^{17-20}$, but also a competitive immunoassay ${ }^{21}$, and an immunofluorometric assay ${ }^{22}$. In most cases monoclonal antibodies are used, and these show virtually no crossreactivity with other FABP types ${ }^{23,24}$. Recombinant H-FABP appears immunochemically equivalent to the tissue-derived protein and, therefore, is now commonly applied as standard in the immunoassay ${ }^{17,24}$.

These assays have been used successfully for retrospective analyses of plasma FABP in patient samples. However, the implication of these tests for clinical decision making in the case of suspected AMI is hampered by the fact that the reported fastest immunoassay ${ }^{17}$ still takes 45 minutes to complete. Therefore, more rapid FABP immunoassays are being developed. To date, these include a microparticle-enhanced turbidimetric assay to be performed on a conventional clinical chemistry analyzer (performance time 10 minutes) ${ }^{25}$, an automated sandwich immunoassay (performance time 23 minutes) ${ }^{26,27}$, and an electrochemical immunosensor(performance time 20 minutes) ${ }^{28-30}$. The electrochemical immunosensor is based on screen printed graphite electrodes and uses an immunosandwich procedure and an amperometric detection system ${ }^{29}$. Measurements of plasma samples from patients with AMI with this immunosensor and with an ELISA show an excellent correlation ${ }^{29,31}$. More recently, a new principle for rapid immunoassay of proteins based on in situ precipitate-enhanced ellipsometry was presented and applied for assay of FABP ${ }^{32}$. This technique enables the development of a one-step ELISA with a performance time of less than 10 minutes. Finally, the development was described of a whole blood panel test for FABP using a one-step immunochromatography technique ${ }^{33}$. This panel test which is completed in 15 minutes and is meant for point-of-care testing, identifies blood samples with an FABP concentration exceeding $6 \mu \mathrm{g} / \mathrm{L}$. With the exception of the ELISA 
assays, calibrated with recombinant $F A B P$, these new techniques still require further evaluation and standardization.

\section{Release and elimination of FABP upon muscle injury}

The release of $H$-FABP from injured muscle was first demonstrated in 1988 with isolated working rat hearts ${ }^{34}$, and indicated the potential use of FABP as a plasma marker of myocardiat injury in humans. Subsequently, several groups reported the release of FABP into plasma of patients with $A M{ }^{18,20,21,35}$. The characteristics of the release of FABP from injured myocardium closely resemble those of myoglobin. As an example, Figure 2 shows mean plasma release curves of FABP and of several other plasma marker proteins for $15 \mathrm{AMI}$ patients (treated with thrombolytic therapy) from whom blood samples were obtained frequently during the first $72 \mathrm{~h}$ of hospitalization ${ }^{36}$. In patients treated with standard thrombolytic therapy after AMI, peak plasma concentrations of FABP and myoglobin are reached already at about $4 \mathrm{~h}$ after first symptoms, whereas for creatine kinase ( $C K$ or $C K-M B)$ this takes about 12 $\mathrm{h}$, and for lactate dehydrogenase (LDH) about $20 \mathrm{~h}$.
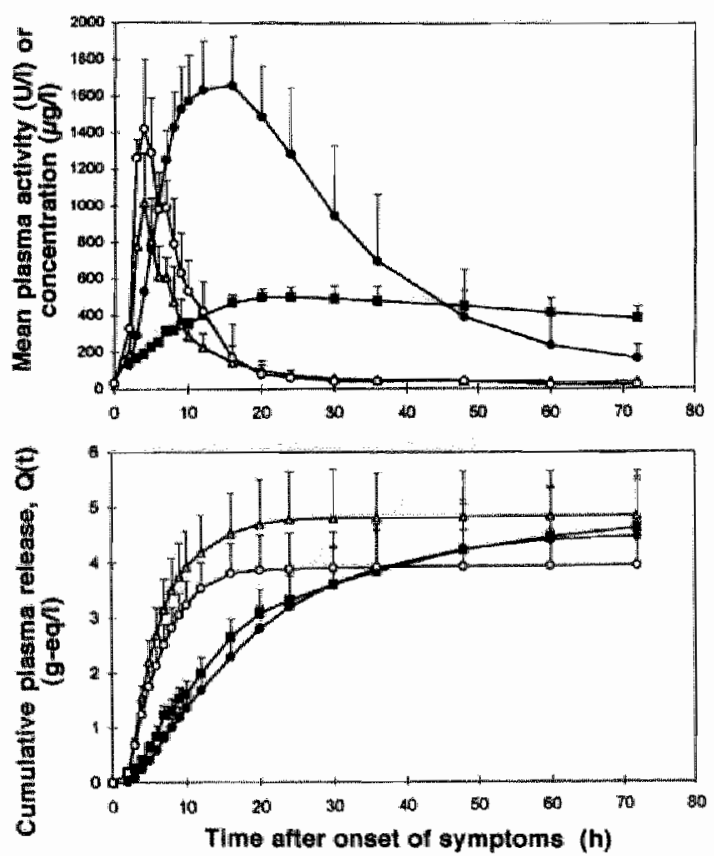

Figure 2. Mean plasma concentration or activities (top panel) and mean cumulative release expressed in gramequivalents (g-eq) of healthy myocardium per liter of plasma (lower panel) of FABP (multiplied by 10, OH, myoglobin $(\Delta)$, creatine kinase actiwity $(\bullet)$ and lactate delydrogenase isoenzyme-1( 1 ) as function of time after onset of symptoms in 15 patients after acute myocardial infarction. Data refer to mean \pm SEM. (Adapted from Reference 37.) 
Furthermore, plasma FABP and myoglobin return to their respective reference values already within $24 \mathrm{~h}$ after AMI (Fig. 2), indicating the usefulness of both markers particularly for the assessment of a recurrent infarction ${ }^{3 \%}$. However, for AMI patients not treated with thrombolytics, peak levels are reached approximately $8 \mathrm{~h}$ after AMI, and elevated plasma FABP and myoglobin concentrations are found up to $24-36 \mathrm{~h}$ after the onset of chest pain ${ }^{37}$. The release of the myofibrillar proteins $\mathrm{TnT}$ and troponin I (Tnl) from injured myocardium follows a different pattern with elevated plasma concentrations occurring from approximately $8 \mathrm{~h}$ up to more than 1 week after infarction ${ }^{3,38}$. Hence, the so-called diagnostic window of the various marker proteins differs considerably.

The marked differences in the time course of plasma concentrations or activities among the cytoplasmic proteins (CK-MB, LDH, FABP, and myoglobin) are caused by 1) a more rapid washout of the smaller proteins (FABP, myoglobin) from the interstitium to the vascular compartment (Fig. 3), and 2) differences among the proteins in their rate of elimination from plasma ${ }^{39}$. Studies of isolated cardiac myocytes subjected to simulated ischemia showed that protein release from the damaged myocytes is independent of molecular mass ${ }^{40}$.

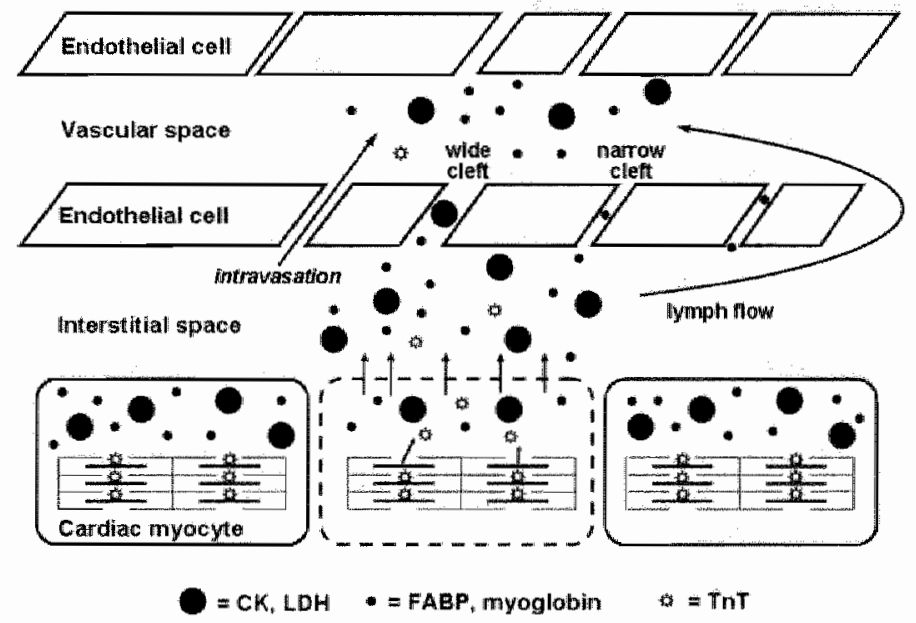

Figure 3. Schematic presentation of the possible transport routes of protein released from damaged cardiac myocytes to the plasma compartment. Proteins can either directly cross the endothelfal cell barrier (predominant route for small proteins such as fatty acid binding protein and myoglobin) or they can be transportted through lymph drainage (predominant route for larger proteins such as cireathe kinase MB [CK] and lactate dehydrogenase [LDH]]. Structurally bound proteins (such as troponin T [TnT]) first must be dissociated from the myofibrillar structures before they can be released into the interstitial space. (Adapted from Reference 41 , with permission.) 


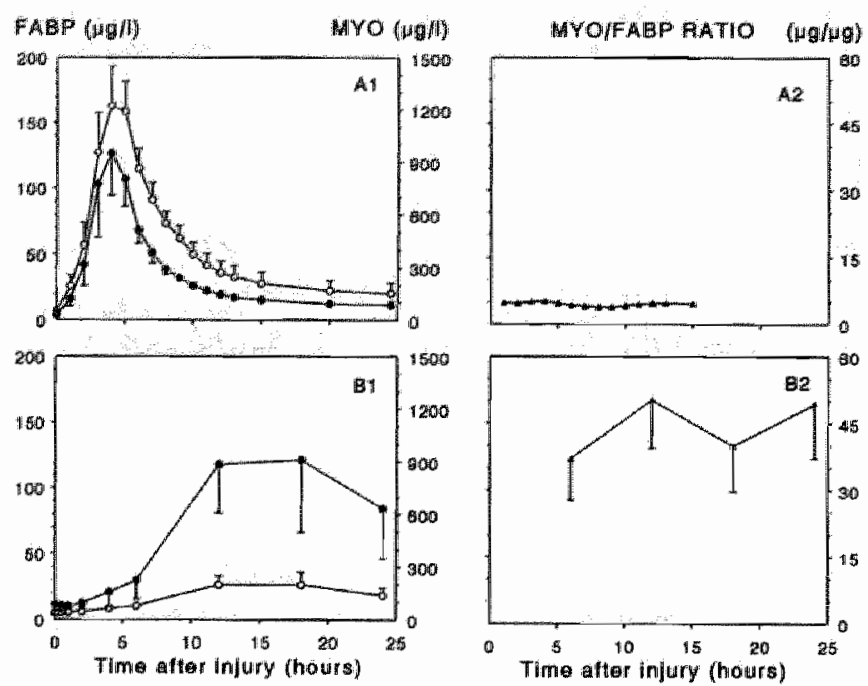

Figure 4. Mean plasma concentrations of myoglobin ( $\mathrm{MYO}$ ) and fatty acid bünding protein (FABP; O) (Left parels) and the myoglobin:FABP ratio (") (right panels) in 9 patients after acute myocardial infarction (and receiving thrombolytic therapy) (A), and in 9 patients after aortic surgery (B). Data refer to mean 1 SEM. (Adapted from Reference 38.)

This indicates that during the protein-release phase the sarcolemma does not act as a selective sieve through which small proteins are preferentially lost. The fact that smaller proteins can be detected in blood plasma earlier after muscle injury than can larger proteins therefore relates to a greater permeability of the endothelial barrier for smaller proteins (Fig. 3) ${ }^{39}$.

With respect to protein elimination from plasma, FABP and myoglobin, unlike the larger cardiac enzymes, are removed from the circulation predominantly by renal clearance ${ }^{18,20,35,39}$. This explains not only their rapid clearance from plasma after AMI (Fig. 2) but also the maintenance of relatively low plasma concentrations of these proteins in healthy individuals.

The plasma concentrations in healthy individuals are determined mainly by the release of protein from skeletal muscle because its total mass far exceeds that of cardiac muscle. Because the skeletal muscle FABP content is relatively low compared with that of myoglobin, the plasma reference concentration of FABP also is relatively low (Table 1) ${ }^{17,41-44}$. This notion is also reflected in the ratio of the concentrations of myoglobin and FABP in plasma from healthy subjects (myoglobin:FABP ratio approximately 20 ) ${ }^{42}$, which resembles the ratio in which these proteins occur in skeletal muscle (myoglobin:FABP ratio 15-70) (see below).

The role of the kidney in the clearance of FABP and myoglobin from plasma further indicates that increased plasma concentrations of these proteins are likely to be found in case of renal insufficiency. Indeed, it has 
Table 1. Comparison of relevant characteristics for $F A B P$ and myoglobin as markers of myocardial injury

\begin{tabular}{ccccc}
\hline Protein & $\begin{array}{c}\text { Molecular Mass } \\
(\mathrm{kD})\end{array}$ & $\begin{array}{c}\text { Cardiac Muscle } \\
\text { Content (mg/g) }\end{array}$ & $\begin{array}{c}\text { Skeletal Muscle } \\
\text { Content }^{*}(\mathrm{mg} / \mathrm{g})\end{array}$ & $\begin{array}{c}\text { Concentration } \\
(\mu \mathrm{g} / \mathrm{L})\end{array}$ \\
\hline FABP & 14.5 & 0.57 & $0.04-0.14$ & 1.8 \\
myoglobin & 17.6 & 2.7 & $2.2-6.7$ & 34 \\
\hline
\end{tabular}

Data are obtained from References $31,37,38$ and 45 .

" Range given for muscles of different fiber type composition. FABP = fatty acid-binding protein.

been reported that patients with chronic renal failure and normal heart function show several-fold increased plasma concentrations of both FABP and myoglobin ${ }^{45,46}$. In addition, Kleine et al. ${ }^{20}$ reported a patient with $A M I$ and severe renal insufficiency in whom the plasma FABP concentration remained markedly elevated for at least $25 \mathrm{~h}$ after infarction.

\section{DISCRIMINATION OF CARDIAC FROM SKELETAL MUSCLE INJURY $\mid<$}

A potential drawback of the use of FABP as plasma marker for monitoring myocardial injury is its presence in significant quantities not only in heart muscle but also in skeletal muscle cells (Table 1). A proper diagnosis of AMI thus may be hampered in case of extensive skeletal muscle injury such as multi-organ failure, post-operative states, or vigorous exercise. However, this problem can be overcome by the combined measurement of myoglobin and FABP concentrations in plasma and expressing the ratio of these, because this plasma ratio is a reflection of the ratio in which these proteins occur in the affected tissue cells and it differs between heart muscle (myoglobin:FABP ratio 4-5) and skeletal muscles (myoglobin:FABP ratio 20-70, depending on type of muscle) (Table 1) ${ }^{3,37,4 \pi}$.

This finding is illustrated in Figure 4 for patients after $A M I$ in whom the plasma myoglobin:FABP ratio was approximately 5 during the entire period of elevated plasma concentrations (upper panels), and for patients who underwent aortic surgery, which causes no-flow ischemia of the lower extremities, in whom the plasma myoglobin:FABP ratio was approximately 45 (lower panels). In addition, van Nieuwenhoven et al. ${ }^{37}$ described a patient who was defibrillated shortly after AMI, a treatment that most likely results in injury of intercostal pectoral muscles, and in whom the plasma myoglobin:FABP ratio increased from 8 to 60 during the first 24 th after AMI. Finally, in case AMI patients show a second increase of plasma concentrations of marker proteins, the ratio may be of help to delineate whether this second increase was caused either by a recurrent infarction or by the occurrence of 
additional skeletal muscle injury. In the former case, the ratio will remain unchanged ${ }^{37}$.

\section{$>$ EARLY DIAGNOSIS OF AMI}

The application of FABP especially for the early diagnosis of acute coronary syndromes is already indicated from 1) its rapid release into plasma after myocardial injury, and 2) its relatively low plasma reference concentration. Several studies have now firmly established that FABP is an excellent plasma marker for the early differentiation of patients with and those without AMI, and that it even performs better than myoglobin. A selection of these studies is discussed here.

Retrospective analyses of various marker proteins in plasma samples from patients with $A M I$ revealed that the diagnostic sensitivity for detection of $A M I$ is better for FABP than for myoglobin or CK-MB, especially in the early hours after the onset of symptoms. For example, in a study including blood samples from 83 patients with confirmed AMI, taken immediately upon admission to the hospital ( $<6 \mathrm{~h}$ after chest pain onset), the diagnostic sensitivity was significantly greater for FABP (78\%, confidence interval $67 \%$ to $87 \%$ ) than for myoglobin (53\%, Cl $40 \%$ to $64 \%$ ) or for CK-MB activity $(57 \%, \mathrm{Cl} 43 \%$ to $65 \%$ ) $(p<0.05)^{44}$.

In the last few years, larger studies have been done that allow for the proper assessment of both the sensitivity and specificity of FABP for AMI diagnosis. In a (single center) study with 165 patients admitted $3.5 \mathrm{~h}$ (median value) after the onset of chest pain, Ishii et al. ${ }^{43}$ found in admission blood samples diagnostic sensitivities and specificities for FABP $(>12 \mu \mathrm{g} / \mathrm{L})$ of $82 \%$ and $86 \%$, respectively, and for myoglobin (>105 $\mu \mathrm{g} / \mathrm{L}$ ) of $73 \%$ and $76 \%$, respectively (FABP versus myoglobin significantly different; $p<0.05$ ). A similar superior performance of FABP over myoglobin, in terms of both sensitivity and specificity of AMI diagnosis, was also observed in a prospective multi-center study consisting of four European hospitals and including 312 patients admitted $3.3 \mathrm{~h}$ (median value; range 1.5-8 h) after the onset of chest pain suggestive of AMI (EUROCARDI Multi-center Trial) ${ }^{47,48}$. For instance, specificities $>90 \%$ were reached for FABP at $10 \mu \mathrm{g} / \mathrm{L}$ and for myoglobin at 90 $\mu \mathrm{g} / \mathrm{L}$. Using these upper reference concentrations in the subgroup of patients admitted within $3 \mathrm{~h}$ after onset of symptoms $(n=148)$, the diagnostic sensitivity of the first blood sample taken was $48 \%$ for FABP and $37 \%$ for myoglobin, whereas for patients admitted 3-6 h after AMI $(n=86)$, the sensitivity was $83 \%$ for FABP and $74 \%$ for myoglobin ${ }^{47,48}$. In addition, the areas under the receiver operating characteristic (ROC) curves, constructed for the admission blood samples from all patients, were 0.901 for FABP and 0.824 for 
myoglobin (significantly different; $p<0.001$ ) (Fig. 5). This better performance of FABP over myoglobin for the early diagnosis of AMI has also been reported in other smaller studies ${ }^{26,49,50}$.

More recently, Okamoto et al. ${ }^{51}$ confirmed the above findings by demonstrating, in a single-center study consisting of 189 patients admitted to hospital within $12 \mathrm{~h}$ after the onset of symptoms, that the area under the ROC curve of FABP was 0.921 , which was significantly $(p<0.05)$ greater than that of myoglobin (0.843) and CK-MB activity (0.654). In addition, a multicenter study consisting of three North-American hospitals and including 460 consecutive patients, reported by Ghani et al. ${ }^{27}$, also revealed a better diagnostic performance of FABP over myoglobin during the first $4 \mathrm{~h}$ after admission, the areas under the ROC curves being 0.80 for FABP and 0.73 for myoglobin. Strikingly, the area under the ROC curve of CK-MB mass was 0.79 , and that of cardiac Tnl was $0.91^{27}$, which made the authors conclude that in their study neither FABP nor myoglobin show the sensitivity and specificity necessary to detect AMI significantly earlier than do the existing markers. This conclusion seemingly contradicts to the well-documented poor diagnostic performance of $\mathrm{CK}-\mathrm{MB}$ mass and TnT or Tnl in the very early hours after infarction (cf. Fig. 6) $1,3,38$. The discrepancy is explained by the fact that the hospital delay time, which was not given, has to be added to the admission time. When assuming a hospital delay of 3-4 h, the study results would apply to the period up to 7-8 $\mathrm{h}$ after the onset of symptoms, whereas FABP and myoglobin are useful especially in the preceding hours.

In some of these above-mentioned studies, investigators evaluated whether the diagnostic performance of FABP as early plasma marker of myocardial injury could further improve when the criterion of a plasma myoglobin:FABP ratio $<10$ (or $<14$ ), ie, the exclusion of skeletal muscle as source of FABP, is taken as an additional parameter $27,43,47,49,52$. In each of these study populations, there were a few cases in which both myoglobin and FABP were elevated in the admission plasma sample, but in which the myoglobin:FABP ratio was greater than 10 (or 14). Without this latter result, these patients would be falsely diagnosed as having had myocardial injury. However, because the prevalence of skeletal muscle injury in these study populations was very low ( $<1 \%$ of cases), this additional parameter did not significantly alter the ROC curve for FABP (Fig. 5). Therefore, the routine measurement of the myoglobin:FABP ratio in samples from patients suspected for $M I$ does not seem justified because it does not add value to the measurement of FABP alone. In addition, the myoglobin:FABP ratio cannot provide absolute cardiac specificity ${ }^{3}$. 


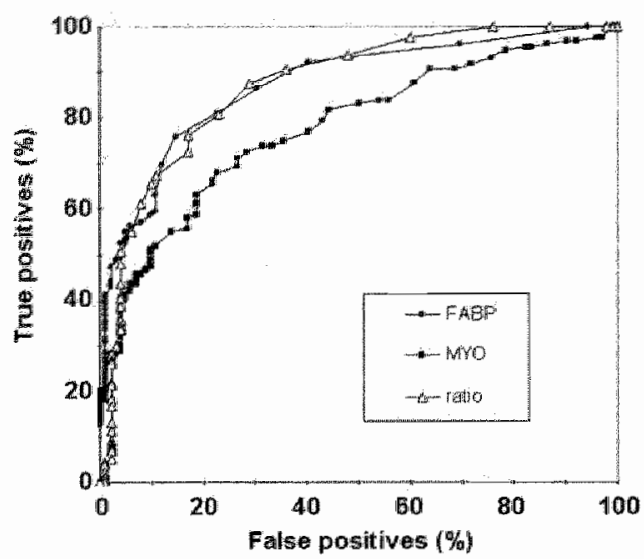

Figure 5. Receiver operating characteristic (ROC) curves for detection of acute myocardial infarction (Awl) in 238 patients with chest pain suggestive of AMl, and admitted to hospital within $6 \mathrm{~h}$ from the onset of symptoms, comparing the concentrations of fatty actd binding protein (FABP; $\bullet$ ) and myoglobin (n), and the myoglobin:FABP ratio (A) in the admission blood sample. ROC curves were constructed by plotting the sensitivity (\% true positives) for the confirmed AMl group (135 patients) against 100 - specificity (\% false positives) for the non-AMl group (103 patients). The areas under the ROC curves are 0.874 for FABP, 0.780 for myoglobin and 0.870 for the myoglobin:FABP ratio (FABP versus myoglobin, and FABP versus the ratio significantlly different; $P<0.001$ ). Data obtained from the EUROCARDI multicenter trial ${ }^{10.50}$.

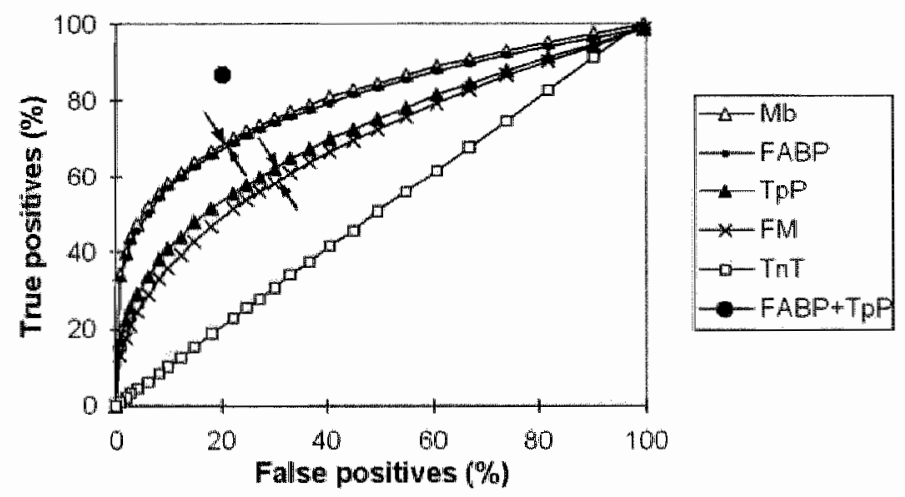

Figure 6. Receiver operating characteristic $(R O C)$ curves for detection of acute myocardial infarction (AMI) in patients having either AMl ( $n=15$ ) or unstable angina pectoris (UAP; $n=10$ ), comparing selected markers of muscle necrosis (fatty acid binding protein [FABP], myoglobin [Mb] and troponin $T$ [TnT]) and markers of actiwated blood coagulation (fibrin monomers [FM] and thrombus precursor protein [TpP]). Median hospital delay was 2.8 h (range 0.8-6 h). ROC curves were obtained from double logarithmic plots. Lack of discrimination by TnT is apparent from its coincidence with the line of identity. Arrows indicate optimal cut-off values. For a combined test, that is when either FABP $>6 \mu \mathrm{g} / \mathrm{L}$ or TpP $>7 \mathrm{mg} / \mathrm{L}$ as diagnostic for AMl, the sensitivity was $87 \%$ and the specificity $80 \%$. (Adlapted from Hermens et al. ${ }^{67}$.) 
At first sight it may be surprising that FABP appears as an earlier marker for AMI detection than does myoglobin, even though the two proteins show similar plasma release curves. However, these findings can be explained when realizing that the myocardial content of $F A B P(0.57 \mathrm{mg} / \mathrm{g}$ wet weight $)$ is fourto five-fold lower than that of myoglobin $(2.7 \mathrm{mg} / \mathrm{g}$ wet weight), yet the plasma reference concentration of FABP $(1.8 \mu \mathrm{g} / \mathrm{L})$ is 19 -fold lower than that of myoglobin $(34 \mu \mathrm{g} / \mathrm{L})$ (Table 1$)$. This means that after injury the tissue to plasma gradient is almost five-fold steeper for FABP than for myoglobin, making plasma FABP rise above its upper reference concentration at an earlier point after $A M \mid$ onset than does plasma myoglobin, thereby permitting an earlier diagnosis of AMI.

It is now firmly documented that the subgroup of patients with unstable angina pectoris who show a significantly increased plasma concentration of $\mathrm{TnT}(>0.2 \mu \mathrm{g} / \mathrm{L})$ have a prognosis as serious as do patients with definite AMI 53,54 . This observation most likely relates to the occurrence in these patients of minor myocardial cell necrosis. In those patients in whom unstable angina pectoris is in fact acute minor MI, the advantage of FABP for early assessment of injury may be used. Recently, Katrukha et al. ${ }^{55}$ measured FABP and Tnl in serial plasma samples from 31 patients with unstable angina and showed that in the admission sample $\mathrm{Tnl}$ was elevated (cut-off value $0.2 \mu \mathrm{g} / \mathrm{L}$ ) in $13 \%$ and FABP (cut-off value $6 \mu \mathrm{g} / \mathrm{L}$ ) in $54 \%$ of patients, whereas at $6 \mathrm{~h}$ after admission $\mathrm{Tn}$ I was elevated in $58 \%$ and FABP in $52 \%$ of patients. Importantly, all patients who had an elevated FABP concentration at $6 \mathrm{~h}$ showed an elevated $\mathrm{Tn} l$ value at $12 \mathrm{~h}$ after admission ${ }^{55}$. These preliminary data suggest that FABP may identify (acute) minor MI with similar sensitivity as $\mathrm{Tnl}$, but at an earlier point after admission of the patient.

\section{EARLY ESTIMATION OF MYOCARDIAL INFARCT SIZE}

Myocardial infarct size is commonly estimated from the serial measurement of cardiac proteins in plasma and calculation of the cumulative release over time (plasma curve area), taking into account the elimination rate of the protein from plasma ${ }^{56}$. This approach requires that the proteins are completely released from the heart after AMI and recovered quantitatively in plasma. Complete recovery is well documented for CK, LDH and myoglobin (but does not apply for the structural proteins $\operatorname{TnT}$ and $\mathrm{Tnl}{ }^{3.8}$ ), and could also be shown for FABP ${ }^{36,57}$. Figure 2 (lower panel) presents the cumulative release patterns of these four proteins, expressed in gram-equivalents ( $\mathrm{g}-\mathrm{eq}$ ) of healthy myocardium per liter of plasma (i.e., infarct size). The release of FABP and myoglobin is completed much earlier than that of either CK or LDH, but despite this kinetic difference for each of the proteins, the released total 
quantities yield comparable estimates of the mean extent of myocardial injury when evaluated at $72 \mathrm{~h}$ after the onset of AMI (Fig. 2).

This method to estimate infarct size has proven its value when applied to the evaluation of early thrombolytic therapy in patients with AMI ${ }^{58}$. With the (classically used) enzymatic markers, the method has the drawback that the data on infarct size in the individual patient become available relatively late $(72 \mathrm{~h})$, i.e., too late to have influence on acute care ${ }^{59}$. For the more rapidly released markers FABP and myoglobin, infarct size estimation for individual patients is hampered by the fact that these proteins are cleared by the kidneys, and the patients often suffer from renal insufficiency, which would lead to overestimation of infarct size. De Groot et al. ${ }^{60}$ recently suggested the use of individually estimated clearance rates for FABP and myoglobin to measure myocardial infarct size within $24 \mathrm{~h}$. These individual clearance rates are calculated using glomerular filtration rates (estimated from plasma creatinine concentrations and corrected for age and gender) and plasma volume (corrected for age and gender). This implies that a reliable estimate of myocardial infarct size becomes available when the patient is still in the acute care department, if frequent blood samples are taken and analyzed rapidly.

\section{$>$ FABP AS REPERFUSION MARKER}

The application of FABP as a plasma marker for the early detection of successful coronary reperfusion in patients with AMI has been investigated by three groups ${ }^{61-63}$. Ishii et al. ${ }^{63}$ studied 45 patients treated with intracoronary thrombolysis or direct percutaneous transluminal coronary angioplasty (PTCA), in whom coronary angiography was performed every 5 minutes to identify the onset of reperfusion. Both plasma FABP and myoglobin were found to rise sharply after the onset of reperfusion, and the relative first-hour increase rates of both markers showed a predictive accuracy of greater than $93 \%$. Subsequently, in a study consisting of 58 patients, de Lemos et al. ${ }^{62}$ also demonstrated that following successful reperfusion plasma FABP and myoglobin rise sharply, whereas in patients with failed reperfusion these markers rise at a much slower rate. In this study the patency of the infarctrelated artery was determined from a single point angiogram, and could be predicted from either plasma FABP or myoglobin with a sensitivity of approximately $60 \%$ and a specificity of approximately $80 \%$. This minor performance of the markers in this study when compared with that of Ishii et al. ${ }^{63}$ may be explained by the strict inclusion criteria in the latter.

In a multi-center study consisting of 115 patients with confirmed AMI and receiving thrombolytic agents, and who underwent coronary angiography 
within 120 minutes of the start of thrombolysis, De Groot et al. ${ }^{61}$ also observed that FABP and myoglobin perform equally well as marker to discriminate between reperfused and non-reperfused patients. Similar to the study of De Lemos et al. ${ }^{62}$ these investigators found relatively low sensitivities and specificities (approximately 70\%), which, however, could be improved (to approximately $80 \%$ ) by normalisation to infarct size ${ }^{6 \%}$. These data indicate the equal suitabilities of FABP and myoglobin as non-invasive reperfusion markers, especially in retrospective studies where infarct size is known.

\section{NEW APPROACHES TO INCREASE FURTHER THE DIAGNOSTIC PERFORMANCE OF FABP}

A limitation of the use of markers of cell necrosis for assessment of tissue injury is the time lag between the onset of necrosis and the appearance of the marker proteins in plasma. This explains why up to 2-3 h after the onset of AMI, the performance of such markers generally is insufficient for clinical decision making. Therefore, approaches have been presented to further increase the diagnostic performance of the plasma markers in these early hours after AMl.

To circumvent the problem of the upper reference concentration that is defined for populations and used for individual cases, it has been suggested to collect two (or more) serial blood samples during the first hours after admission and express the difference in marker concentration or activity in these samples. This approach has been applied especially to identify low-risk patients who would show no ECG abnormalities as well as two negative results for protein markers (hence, no significant change with time), and for whom early discharge would be a safe option ${ }^{64}$. In a second EUROCARDI Multicenter Trial, we studied whether in patients admitted for suspected AMI without ECG changes, AMI can be ruled out by assay of FABP, myoglobin or CK-MB mass in two serial blood samples, collected upon admission and $1.3 \mathrm{~h}$ thereafter, respectively. For comparison, TnT was measured in a third sample taken 12-36 $\mathrm{h}$ after admission. Preliminary results from this study revealed that two negative marker concentrations within $3 \mathrm{~h}$ from admission ruled out AMI with very high negative predictive values $(>90 \%)$ with the highest value found for FABP (negative predictive value $98 \%$ ), being similar to that of TnT elevation $(\geq 0.1 \mu \mathrm{g} / \mathrm{L})$ in the sample taken $12-36 \mathrm{~h}$ after admission (B. Haastrup et al., unpublished data, 1999). A similar conclusion was also reached in a subsequent single-center study consisting of 130 patients admitted for suspected AMI with no significant ST-segment elevation ${ }^{65}$. These data indicate 
the excellent utility of FABP for early triage and risk stratification of patients with chest pain.

Another approach to further increase the diagnostic performance of FABP in the early hours after onset of chest pain is its use in combination with markers of activated blood coagulation ${ }^{66}$. Because intracoronary formation of blood clots on ruptured arteriosclerotic plaques is considered the main cause of AMI, detection of activated blood coagulation potentially allows for the early diagnosis of $A M{ }^{67}$. Various (small-size) studies have indicated that in the very early hours $(0-3 \mathrm{~h})$ after AMl onset, coagulation markers show a higher sensitivity and specificity for AMI detection than necrosis markers ${ }^{68,69}$. In addition, a tendency toward higher marker concentrations was observed for shorter hospital delays, a finding related to the fact that the acute thrombotic event precedes coronary occlusion and muscle necrosis. In a pilot study consisting of 25 patients with either AMI or unstable angina pectoris, we showed that combining a marker of muscle cell necrosis (FABP) and a marker of activated blood coagulation (thrombus precursor protein [TpP]) yielded a markedly higher sensitivity and specificity for AMI detection than either of the markers alone (Fig. 6) ${ }^{66}$. Moreover, the performance of such a combined test is expected to be relatively insensitive to hospital delay because TpP will perform better in patients who are admitted earlier, whereas FABP will perform better in patients who are admitted later ${ }^{37,69}$. A general problem in this field of research is that the tight physiological control of blood coagulation, required to prevent thrombolysis, is affected by a large number of feed-back mechanisms and inhibitors that may easily obscure the relation between the extent of prothrombolytic activation and the concentrations of activated products in plasma.

\section{$>\mid$ OTHER APPLICATIONS OF THE PLASMA MARKER FABP}

FABP was also found to be useful for the early detection of postoperative myocardial tissue loss in patients undergoing coronary bypass surgery ${ }^{3,71 \cdot 73}$. In these patients, myocardial injury may be caused by global ischemia/reperfusion and, additionally, by postoperative MI. In our study, we found that in such patients plasma $C K$, myoglobin, and FABP are already significantly elevated $0.5 \mathrm{~h}$ after reperfusion. In the patients who developed postoperative $\mathrm{Ml}$, a second increase was observed for each plasma marker protein, but a significant increase was recorded earlier for FABP ( $4 \mathrm{~h}$ after reperfusion) than for CK or myoglobin ( $8 \mathrm{~h}$ after reperfusion) ${ }^{71}$. These data suggest that FABP would allow for an earlier exclusion of postoperative Ml, thus permitting the earlier transfer of these patients from the intensive care unit to the ward. Recently, both Hayashida et al. ${ }^{72}$ and Petzold et al. ${ }^{73}$ also 
reported that FABP is an early and sensitive marker for the diagnosis of myocardial injury in patients undergoing cardiac surgery.

Antibodies directed against FABP have been shown to be useful for the immunohistochemical detection of very recent $M / \mathrm{s}^{74.76}$. Partial depletion of FABP was observed in cardiomyocytes with a post-infarction interval of less than $4 \mathrm{~h}^{74}$, indicating that FABP immunostaining can confirm the clinical diagnosis or suspicion of early $M I$ in routine autopsy pathology.

Finally, besides the application of FABP in early diagnosis of myocardial injury in patients, the marker is now also applied for evaluating MI after coronary artery ligation and for estimating infarct size in experimental animals such as mice and rats ${ }^{77-80}$.

\section{CONCLUDING REMARKS}

The early diagnosis of acute coronary syndromes is important because it may improve patient treatment and reduce complications. Biochemical markers of myocardial cell damage continue to be important tools for differentiating patients with AMI from those without AMI, because specific ST. segment changes in the admission ECG remain absent in a great number of patients with $A M 1^{1,3}$. FABP is a novel biochemical marker that shows release characteristics from injured myocardium and elimination rates from plasma that are similar to those of myoglobin, which presently is regarded as the preferred early plasma marker of cardiac injury ${ }^{52,81-83}$. Experimental studies indicate that this resemblance relates to the similar molecular masses of FABP $(14.5 \mathrm{kD})$ and myoglobin $(17.6 \mathrm{kD})$. Several clinical studies with patients suspected of having AMI reveal a superior performance of FABP over myoglobin (as well as other marker proteins) for the early detection of AMI. This finding most likely relates to marked differences in tissue contents of FABP and myoglobin in cardiac and skeletal muscles that result in a relatively low upper reference concentration in plasma for FABP compared with that for myoglobin. These differences in tissue contents are also reflected in the plasma concentrations of these proteins after either cardiac or skeletal muscle injury, in such a manner that the ratio of the plasma concentrations of myoglobin and FABP can be applied to discriminate myocardial from skeletal muscle injury.

Limitations of the use of FABP as a diagnostic plasma marker in the clinical setting include 1) the relatively small diagnostic window, which extends to only 24-30 h after the onset of chest pain, and 2) its elimination from plasma mainly by renal clearance, possibly causing falsely high values in case of kidney malfunction. These drawbacks can, however, be overcome by the simultaneous measurement in plasma of a late marker such as TnT or TnI 
and assay of plasma creatinine to identify patients with renal insufficiency and to calculate a corrected FABP concentration. It is important to note that these same limitations also apply to myoglobin, which is now recommended by both the National Academy of Clinical Biochemistry (NACB) Committee on Standards of Laboratory Practice ${ }^{81}$ and the International Federation of Clinical Chemistry (IFCC) Committee on Standardization of Markers of Cardiac Damage ${ }^{52}$ as preferred early marker of Ml, to be used in combination with cardiac TnT or cardiac Thl. In spite of the recognition that, to date, relatively few centers, have investigated the performance of FABP for early diagnosis of AMI, the uniformly observed superiority of FABP over myoglobin indicates that the optimal set of biochemical markers of muscle necrosis for assessment of acute coronary syndromes may be FABP together with cardiac TnT or cardiac Tnl ${ }^{84}$. 
1. Adams JE, 3rd, Abendschein DR, Jaffe AS. Biochemical markers of myocardial injury. Is MB creatine kinase the choice for the 1990s? Circulation. $1993 ; 88: 750-63$.

2. Christenson $\mathrm{RH}, \mathrm{Azzazy} H \mathrm{M}_{*}$ Biochemical markers of the acute coronary syndromes. Clin Chem. 1998;44:1855-64.

3. Mair J. Progress in myocardial damage detection: new biochemical markers for clinicians. Crit Rev Clin Lab Sci. 1997;34:1-66.

4. Glatz $J F$, van der Vusse $G J$. Cellular fatty acid-binding proteins: their function and physiological significance. Prog Lipid Res. 1996;35:243-82.

5. Banaszak L, Winter $N$, Xu Z, Bernlohr DA, Cowan S, Jones TA. Lipid-binding proteins: a family of fatty acid and retinoid transport proteins. Adv Protein Chem. 1994;45:"89-151.

6. Schreiber A, Specht B, Pelsers MM, Glatz JF, Borchers T, Spener F. Recombinant human heart-type fatty acid-binding protein as standard in immunochemical assays. Clin Chem Lab Med. 1998;36:283-8.

7. Schaap FG, Specht B, van der Vusse GJ, Borchers T, Glatz JF. One-step purification of rat heart-type fatty acid-binding protein expressed in Escherichia coli. J Chromatogr B Biomed Appl. 1996;679:61-7.

8. van Breda $E$, Keizer HA, Vork MM, Surtel DA, de Jong YF, van der Vusse GJ, Glatz JF. Modulation of fatty-acid-binding protein content of rat heart and skeletal muscle by endurance training and testosterone treatment. Pflugers Arch. 1992;421:274-9.

9. Glatz JF, van Breda $E$, Keizer $H A$, de Jong $Y F$, Lakey JR, Rajotte RV, Thompson A, van der Vusse GJ, Lopaschuk GD. Rat heart fatty acid-binding protein content is increased in experimental diabetes. Biochem Biophys Res Commun. 1994;199:639-46.

10. Kragten $J A_{g}$ van Nieuwenhoven $F A_{\text {, }}$ van Dieijen-Visser MP, Theunissen PH, Hermens WT, Glatz JF. Distribution of myoglobin and fatty acid-binding protein in human cardiac autopsies. Clin Chem. 1996;42:337-8.

11. Vork MM, Trigault $N$, Snoeckx $L H$, Glatz JF, van der Vusse GJ. Heterogeneous distribution of fatty acid-binding protein in the hearts of Wistar Kyoto and spontaneously hypertensive rats. J Mol Cell Cardiol. 1992;24:317-21.

12. Glatz JF, Storch $\mathrm{J}$. Unravelling the significance of cellular fatty acid-binding proteins. Curr Opin Lipidol. 2001;12:267-74.

13. Schaap FG, Binas B, Danneberg $H$, van der Vusse $G J$, Glatz JF. Impaired long. chain fatty acid utilization by cardiac myocytes isolated from mice lacking the heart-type fatty acid binding protein gene. Circ Res. 1999;85:329-37.

14. van der Lee KA, Vork MM, De Vries JE, Willemsen PH, Glatz JF, Reneman RS, Van der Vusse GJ, Van Bilsen M. Long-chain fatty acid-induced changes in gene expression in neonatal cardiac myocytes. J Lipid Res. 2000;41:41-7. 
15. Glatz JF, Borchers $T$, Spener $F$, van der Vusse GJ. Fatty acids in cell signalling: modulation by lipild binding proteins. Prostaglandins Leukat Essent Fatty Acids. 1995;52:121-7.

16. van der Vusse GJ, Glatz JF, 5 tam HC, Reneman RS. Fatty acid homeostasis in the normoxic and ischemic heart. Physjol Rev. 1992;72:881-940.

17. Wodzig KW, Pelsers MM, van der Vusse GJ, Roos W, Glatz JF. One-step enzyme-linked immunosorbent assay (ELISA) for plasma fatty acid-binding protein. Ann Clin Biochem. 1997;34 (Pt 3):263-8.

18. Tanaka $T$, Hirota $Y$, Sohmiya $K$, Nishimura 5 , Kawamura $K$. Serum and urinary human heart fatty acid-binding protein in acute myocardial infarction. Clin Biochem. 1991;24:195-201.

19. Ohkaru $Y$, Asayama $K$, Ishii $H$, Nishimura $S$, Sunahara $N$, Tanaka $T$, Kawamura $K$. Development of a sandwich enzyme-linked immunosorbent assay for the determination of human heart type fatty acid-binding protein in plasma and urine by using two different monoclonal antibodies specific for human heart fatty acid-binding protein. $J$ Immunol Methods. 1995;178:99-111.

20. Kleine $A H$, Glatz JF, Van Nieuwenhoven FA, Van der Vusse G.J. Release of heart fatty acid-binding protein into plasma after acute myocardial infarction in man. Mol Cell Biochem. 1992;116:155-62.

21. Knowlton AA, Burrier RE, Brecher P. Rabbit heart fatty acid-binding protein. Isolation, characterization, and application of a monoclonal antibody. Circ Res. 1989;65:981-8.

22. Katrukha $A G$, Bereznikova $A V$, Filatov $V$. Development of sandwich timeresolved immunofluorometric assay for the quantitative determination of fatty acid-binding protein (FABP). Clin Chem. 1997;43:5106 (abstract).

23. Roos W, Eymann E, Symannek $M$, Duppenthaler J, Wodzig KW, Pelsers $M$, Glatz IF. Monoclonal antibodies to human heart fatty acid-binding protein. $J$ Immunol Methods. 1995;183:149-53.

24. Lucke $C$, Rademacher M, Zimmerman AW, van Moerkerk HT, Veerkamp JH, Ruterjans $H$. Spin-system heterogeneities indicate a selected-fit mechanism in fatty acid binding to heart-type fatty acid-binding protein (H-FABP). Biochem J. 2001;354:259-66.

25. Robers $M$, Van der Hulst $F F$, Fischer MA, Roos W, Salud $C E$, Eisenwiener HG, Glatz JF. Development of a rapid microparticle-enhanced turbidimetric immunoassay for plasma fatty acid-binding protein, an early marker af acute myocardial infarction. Clin Chem. 1998;44:1564-7.

26. Sanders GT, Schouten $\gamma$, De Winter RJ. Evaluation of human heart-type fatty acid-binding protein assay for early detection of myocardial infarction. Clin Chem. 1998; 44:A132.

27. Ghani F, Wu AH, Graff L, Petry C, Armstrong G, Prigent F, Brown M. Role of heart-type fatty acid-binding protein in early detection of acute myocardial infarction. Clin Chem. 2000;46:718-9. 
28. Siegmann-Thoss $C$, Renneberg $R$, Glatz JFC. Enzyme immunosensor for diagnosis of myocardial infarction. Sensors Actuators. 1996, B $30: 71-76$.

29. Schreiber $A_{2}$, Feldbrugge R, Key G, Glatz JF, Spener F. An immunosensor based on disposable electrodes for rapid estimation of fatty acid-binding protein, an early marker of myocardial infarction. Biosens Bioelectron. 1997;12:1131-7.

30. Renneberg $R$, Cheng S, Kaptein WA. Novel immunosensors for rapid diagnosis of acute myocardial infarction: a case report. AdW Biosens. 1999;4:241+272.

31. Key $G$, Schreiber A, Feldbrugge $R$, McNeil $C J$, Jorgensen P, Pelsers MM, Glatz $J_{F}$, Spencer $F$. Multicenter evaluation of an amperometric immunosensor for plasma fatty acid-binding protein: an early marker for acute myocardial infarction. Clin Biochem. 1999;32:229-31.

32. Robers $M$, Rensink $I J$, Hack $C E$, Aarden $L A_{*}$ Reutelingsperger $C P$, Glatz JF, Hermens WT. A new principle for rapid immunoassay of proteins based on in situ precipitate-enhanced ellipsometry. Biophys J. 1999;76:2769-76.

33. Watanabe $T$, Onkubo $Y$, Matsuoka $H$, Kimura $H$, Sakai $Y$, Ohkaru $Y$, Tanaka $T$, Kitaura Y. Development of a simple whole blood panel test for detection of human heart-type fatty acid-binding protein. Clin Biochem. 2001;34:257-63.

34. Glatz JF, van Bilsen $M$, Paulussen RJ, Veerkamp JH, van der Vusse GJ, Reneman RS. Release of fatty acid-binding protein from isolated rat heart subjected to ischemia and reperfusion or to the calcium paradox. Biochim Biophys Acta. 1988;961:148-52.

35. Tsuji R, Tanaka T, Sohmiya K, Hirota Y, Yoshimoto K, Kinoshita K, Kusaka $Y$, Kawamura $K$, Morita $H$, Abe $S$, et al. Human heart-type cytoplasmic fatty acidbinding protein in serum and urine during hyperacute myocardial infarction. Int J Cardiol. 1993;41:209-17.

36. Wodzig KW, Kragten JA, Hermens WT, Glatz JF, van Dieijen-Visser MP. Estimation of myocardial infarct size from plasma myoglobin or fatty acidbinding protein. Influence of renal function. Eur $\mathrm{J}$ Clin $\mathrm{Chem} \mathrm{Clin}$ Biochem. 1997; 35:191-8.

37. Van Nieuwenhoven FA, Kleine AH, Wodzig WH, Hermens WT, Kragten HA, Maessen JG, Punt CD, Van Dieijen MP, Van der Vusse GJ, Glatz. JF. Discrimination between myocardial and skeletal muscle injury by assessment of the plasma ratio of myoglobin over fatty acid-binding protein. Circulation. $1995 ; 92: 2848-54$.

38. Kragten JA, Hermens WT, van Dieijen-Visser MP. Cardiac troponin $T$ release into plasma after acute myocardial infarction: only fractional recovery compared with enzymes. Ann Clin Biochem. 1996;33 ( Pt 4):314-23.

39. Hermens WT. Mechanisms of protein release from injured heart muscle. Cardiovasc Med. 1998;205:85-98.

40. Van Nieuwenhoven FA, Musters RJ, Post JA, Verkleij AJ, Van der Vusse GJ, Glatz JF. Release of proteins from isolated neonatal rat cardiomyocytes 
subjected to simulated ischemia or metabolic inhibition is independent of molecular mass. J Mol Cell Cardiol. 1996;28:1429-34.

41. Yoshimoto $K$, Tanaka $T$, Somiya $K$, Tsuji $R$, Okamoto $F$, Kawamura $K$, Ohkaru $Y$, Asayama $K$, Ishif $H$. Human heart-type cytoplasmic fatty acid-binding protein as an inidicator of acute myocardial infarction. Heart Vessels. 1995:10:304-9.

42. Pelsers $M M$, Chapelle JP, Knapen $M_{v}$ Vermeer $C$, Muijtjens $A M$, Hermens WT, Glatz JF. Influence of age and sex and day-to-day and within-day biological variation on plasma concentrations of fatty acid-binding protein and myoglobin in healthy subjects. Clin Chem. 1999;45:441-3.

43. Ishii J, Wang JH, Naruse $H$, Taga $S$, Kinoshita $M$, Kurokawa $H$, Iwase $M$, Kondo $T$, Nomura $M$, Nagamura $Y$, Watanabe $Y$, Hishida $H$, Tanaka $T$, Kawamura $K$. Serum concentrations of myoglobin vs human heart-type cytoplasmic fatty acid-binding protein in early detection of acute myocardial infarction. Clin Chem. 1997;43:1372-8.

44. Glatz JF, van der Vusse GJ, Simoons ML, Kragten JA, van Dieijen-Visser MP, Hermens WT. Fatty acid-binding protein and the early detection of acute myocardial infarction. Clin Chim Acta. 1998;272:87-92.

45. Nayashida N, Chihara S, Tayama E, Akasu K, Kai E, Kawara T, Aoyagi S. Influence of renal function on serum and urinary heart fatty acid-binding protein levels. $J$ Cardiovasc Surg (Torino). 2001;42:735-40.

46. Gorski J, Hermens WT, Borawski J, Mysliwiec M, Glatz JF. Increased fatty acid-binding protein concentration in plasma of patients with chronic renal failure. Clin Chem. 1997; 43:193-5.

47. Glatz JF, Haastrup B, Hermens WT, de Zwaan C, Barker J, MCNeill CJ, Adams $P$, Luscher M, Ravkilde J, Thygesen $K$, Kristensen $S$, Horder M. Fatty acidbinding protein and the early detection of acute myocardial infarction. The EUROCARDI multicenter trial. Circulation. 1997;96:1-215 (abstract).

48. Kristensen SR, Haastrup B, Horder M. Fatty acid-binding protein: a new early marker of AMI. Scand J Clin Lab Invest. 1996;56 suppl:36-37 (abstract).

49. Abe S, Saigo M, Yamashita T. Heart fatty-acid binding protein is useful in early and myocardial-specific diagnosis of acute myocardial infarction. Circulation. 1996;94:1-323 (abstract).

50. Panteghini $M$, Bonora $R_{n}$ Pagani $F$. Heart fatty-acid binding protein in comparison with myoglobin for the early detection of acute myocardial infarction. Clin Chem. 1997;43:5157 (abstract).

51. Okamoto $F$, Sohmiya $K$, Ohkaru $Y$, Kawamura $K$, Asayama K, Kimura $H$, Nishimura S, Ishii $H$, Sunahara $N$, Tanaka T. Human heart-type cytoplasmic fatty acid-binding protein (H-FABP) for the diagnosis of acute myocardial infarction. Clinical evaluation of H-FABP in comparison with myoglobin and creatine kinase isoenzyme MB. Clin Chem Lab Med. 2000;38:231-8. 
52. Panteghini $M$, Apple FS, Christenson RH, Dati F, Mair J, Wu AH. Use of biochemical markers in acute coronary syndromes. IFCC Sclentific Division, Committee on Standardization of Markers of Cardiac Damage. International Federation of Clinical Chemistry. Clin Chem Lab Med. 1999;37:687-93.

53. Hamm CW, Ravkilde J, Gerhardt $W$, Jorgensen $P$, Peheim $E$, Ljungdahl L, Goldmann B, Katus HA. The prognostic value of serum troponin $T$ in unstable angina. N Engl J Med. 1992;327:146-50.

54. Rawkilde $J$, Horder $M$, Gerhardt $W$, Ljungdahl $L$, Pettersson T, Tryding $N$, Moller BH, Hamfelt A, Graven T, Asberg A, et al. Diagnostic performance and proginostic value of serum troponin $T$ in suspected acute myocardial infarction. Scand J Clin Lab Invest. 1993;53:677-85.

55. Katrukha $A G$, Bereznikova AV, Filatov $V$. Improved detection of minor ischemic cardiac injury in patients with unstable angina by measurement of cTinl and fatty acid-binding protein (FABP). Clin Chem. 1999;45:A139 (abstract).

56. Hermens WT, van der Veen FH, Willems GM, Mullers-Boumans ML, Schrijversvan Schendel A, Reneman RS. Complete recovery in plasma of enzymes lost from the heart after permanent coronary artery occlusion in the dog. Circulation. 1990;81:649-59.

57. Glatz JF, Kleine AH, van Nieuwenhoven FA, Hermens WT, van Dieijen-Visser MP, van der Vusse GJ. Fatty-acid-binding protein as a plasma marker for the estimation of myocardial infarct size in humans. Br Heart J. 1994;71:135-40.

58. Simoons $M L$, Serruys PW, van den Brand $M$, Res $J$, Verheugt $F W$, Krauss $X H$, Remme WJ, Bar F, de Zwaan C, van der Laarse A, et al. Early thrombolysis in acute myocardial infarction: limitation of infarct size and improved survival. $J$ Am Coll Cardiol. 1986;7:717-28.

59. van der Laarse A. Rapid estimation of myocardial infarct size. Cardiovasc Res. $1999 ; 44: 247-8$.

60. de Groot MJ, Wodzig KW, Simoons ML, Glatz JF, Hermens WT. Measurement of myocardial infarct size from plasma fatty acid-binding protein or myoglobin, using individually estimated clearance rates. Cardiovasc Res. 1999;44:315-24.

61. de Groot MJ, Muijtjens AM, Simoons ML, Hermens WT, Glatz JF. Assessment of coronary reperfusion in patients with myocardial infarction using fatty acid binding protein concentrations in plasma. Heart. 2001;85:278-85.

62. de Lemos JA, Antman EM, Morrow DA, Llevadot J, Giugliano RP, Coulter SA, Schuhwerk KC, Arslanian S, MCCabe CH, Gibson CM, Rifai N. Heart-type fatty acid binding protein as a marker of reperfusion after thrombolytic therapy. Clin Chim Acta. 2000;298:85-97.

63. Ishii J, Nagamura $Y$, Nomura $M$, Wang JH, Taga $S$, Kinoshita $M$, Kurokawa $H$, Iwase $M$, Kondo $T$, Watanabe $Y$, Hishida $H$, Tanaka $T$, Kawamura K. Early detection of successful coronary reperfusion based on serum concentration of 
human heart-type cytoplasmic fatty acid-binding protein. Clin Chim Acta. $1997 ; 262: 13-27$.

64. Noble MI. Can negative results for protein markers of myocardial damage justify discharge of acute chest pain patients after a few hours in hospital? Eur Heart J. 1999;20:925-7.

65. Haastrup B, Gill S, Kristensen SR, Jorgensen PJ, Glatz JF, Haghfelt T, Horder M. Biochemical markers of ischaemia for the early identification of acute myocardial infarction without St segment elevation. Cardiology. 2000;94:25461.

66. Hermens WT, Pelsers MM, Mullers-Boumans ML, de Zwaan C, Glatz JF. Combined use of markers of muscle necrosis and fibrinogen conversion in the early differentiation of myocardial infarction and unstable angina. Clin Chem. 1998;44:890-2.

67. Jesse RL, Kontos MC. Evaluation of chest pain in the emergency department. Curr Probl Cardiol. 1997;22:149-236.

68. Merlini PA, Bauer KA, Oltrona L, Ardissino D, Cattaneo M, Belli C, Mannucci $\mathrm{PM}$, Rosenberg RD. Persistent activation of coagulation mechanism in unstable angina and myocardial infarction. Circulation. 1994;90:61-8.

69. Carville DG, Dimitrijevic N, Walsh M, Digirolamo T, Brill EM, Drew N, Gargan PE. Thrombus precursor protein (TpP): marker of thrombosis early in the pathogenesis of myocardial infarction. Clin Chem. 1996;42:1537-41.

70. Van der Putten RFM, Hermens WT, Giesen PLA, te Velthuis H, Aarden LA, Glatz JFC. Plasma tissue factor in the early differentiation of myocardial infarction and unstable angina. Abstract book of the European Meeting on Biomarkers of Organ Damage and Dysfunction, Cambridge UK, April 3-7, 2000.116 (abstract).

71. Fransen EJ, Maessen JG, Hermens WT, Glatz JF. Demonstration of ischemiareperfusion injury separate from postoperative infarction in coronary artery bypass graft patients. Ann Thorac Surg. 1998;65:48-53.

72. Hayashida N, Chihara 5, Akasu K, Oda T, Tayama E, Kai E, Kawara T, Aoyagi S. Plasma and urinary levels of heart fatty acid-binding protein in patients undergoing carcliac surgery. Jpn Circ J. 2000;64:18-22.

73. Petzold T, Feindt P, Sunderdiek U, Boeken U, Fischer $Y$, Gams E. Heart-type fatty acid binding protein (hFABP) in the diagnosis of myocardial damage in coronary artery bypass grafting. Eur $J$ Cardiothorac Surg. 2001;19:859-64.

74. Kleine AH, Glatz JF, Havenith MG. Immunohistochemical detection of very recent myocardial infarctions in man with antibodies against heart-type fatty acid-binding protein. Cardiovasc Pathal. 1993;2:63-69.

75. Ortmann C, Pfeiffer $H$, Brinkmann B. A comparative study on the immunohistochemical detection of early myocardial damage. Int $\mathrm{J}$ Legal Med. 2000;113:215-20. 
76. Watanabe $K$, Wakabayashi $H$, Veerkamp JH, Ono $T$, Suzuki $T$. Immunohistochemical distribution of heart-type fatty acid-binding protein immunoreactivity in normal human tissues and in acute myocardial infarct. $J$ Pathol. 1993;170:59-65.

77. Knowlton AA, Apstein CS, Saouf $R$, Brecher P. Leakage of heart fatty acid binding protein with ischemia and reperfusion in the rat. $J \mathrm{Mol}$ Cell Cardiol. 1989;21:577-83.

78. Volders PG, Vork MM, Glatz JF, Smits JF. Fatty acid-binding proteinuria diagnoses myocardial infarction in the rat. Mol Cell Biochem. 1993;123:18590.

79. Sohmiya $K$, Tanaka $T$, Tsuji $R$, Yoshimoto K, Nakayama $Y$, Hirota $Y$, Kawamura $K$, Matsunaga $Y$, Nishimura $S$, Miyazaki $H$. Plasma and urinary heart-type cytoplasmic fatty acid-binding protein in coronary occlusion and reperfusion induced myocardial injury model. J Mol Cell Cardiol. 1993;25:1413-26.

80. Aartsen WM, Pelsers MM, Hermens WT, Glatz JF, Daemen MJ, Smits JF. Heart fatty acid binding protein and cardiac troponin $T$ plasma concentrations as markers for myocardial infarction after coronary artery ligation in mice. Pflugers Arch. 2000;439:416-22.

81. Wu AH, Apple FS, Gibler WB, Jesse RL, Warshaw MM, Valdes R, Jr. National Academy of Clinical Biochemistry Standlards of Laboratory Practice: recommendations for the use of cardiac markers in coronary artery diseases. Clin Chem. 1999;45:1104-21.

82. Storrow $A B$, Gibler WB. The role of cardiac markers in the emergency department. Clin Chim Acta. 1999;284:187-96.

83. Alpert $\mathrm{J} S$, Thygesen $\mathrm{K}$, Antman $\mathrm{E}$, Bassand JP. Myocardial infarction redefined- a consensus document of The Joint European Society of Cardiology/American College of Cardiology Committee for the redefinition of myocardial infarction. J Am Coll Cardiol. 2000;36:959-69.

84. Wu AH. Analytical and clinical evaluation of new diagnostic tests for myocardial damage. Clin Chim Acta. 1998;272:11-21. 


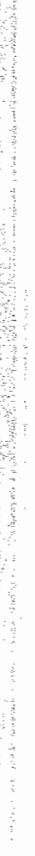




\title{
CHAPTER 6
}

\section{STATE AND DIAGNOSTIC VALUE OF PLASMA TISSUE FACTOR IN EARLY-HOSPITALIZED PATIENTS WITH CHEST PAIN}

\author{
RFM van der Putten ${ }^{1}, \mathrm{H}$ te Velthuis ${ }^{2}, \mathrm{C}$ de Zwaan $^{3}$, LA Aarden ${ }^{2}$, JFC Glatz ${ }^{1}$ \\ and WT Hermens ${ }^{1}$ \\ ${ }^{1}$ Cardiovascular Research Institute Maastricht (CARIM), Maastricht University, \\ Maastricht, the Netherlands \\ ${ }^{2}$ Sanquin Research, Department of Immunopathology and Laboratory for \\ Experimental and Clinical Immunology, University of Amsterdam, Amsterdam, \\ the Netherlands \\ ${ }^{3}$ Department of Cardiology, Maastricht University Hospital, Maastricht, the \\ Netherlands
}

Accepted for publication in the British Journal of Haematology 
To study the state and diagnostic value of plasma tissue factor (TF) in patients with acute coronary syndromes (ACS), we quantitatively compared plasma TF antigen and TF activity in 90 early-hospitalized patients with chest pain.

Using high-affinity antibodies, a sensitive assay for TF antigen was developed with a detection limit of $40 \mathrm{fM}$. One of the antibodies was used to capture TF from plasma and, after elution and dialysis-free reconstitution in phospholipid-glucoside micelles, absolute amounts of TF activity could be measured with a detection limit of $80 \mathrm{fM}$.

All TF in plasma was found to be exposed, and a value of $2.5(1.1-14.8) \mathrm{pM}$ (median with range) was found for TF antigen. Most of this TF antigen (70$80 \%$ ) circulated in a (potentially) functional state. Left in its in vivo state, however, TF captured from plasma was totally inactive, probably due to the lack of a procoagulant matrix.

Compared to controls with non-cardiac chest pain, TF activity was unchanged and TF antigen about $25 \%$ elevated in ACS patients. Combined with the markers prothrombin fragment $1+2(F 1+2)$ and fatty acid-binding protein (FABP), TF did not improve the early diagnosis of ACS. 


\section{INTRODUCTION}

Intra-coronary thrombosis plays a key role in the pathogenesis of acute coronary syndromes (ACS), i.e., unstable angina pectoris (UAP) and acute myocardial infarction (AMI) 1,2 . Until recently, arterial thrombosis was considered to be caused by the interaction of tissue factor (TF) in the vascular wall, exposed after injury, with coagulation factors and platelets in blood. However, TF antigen has also been found to be present in plasma from healthy subjects ${ }^{3-6}$, and several studies reported increased plasma TF antigen in patients with UAP ${ }^{7-10}$ and in patients with AMI ${ }^{11 \cdot 13}$. Interpretation of these data is complicated by the fact that it is presently unknown to which degree plasma TF antigen is in its functional state, or could be reactivated to such a state by pathophysiological triggers such as the production of procoagulant microvesicles by (injured) cells ${ }^{14 \cdot 16}$.

The fact that only a few groups have reported data on plasma TF activity reflects the difficulty of measuring such activity directly in plasma, i.e., in the presence of its natural positive and negative feedback mechanisms. In the acute phase of ACS, for instance, direct consumption of blood TFPI (tissue factor pathway inhibitor), the main endogenous TF inhibitor, has been demonstrated in the heart ${ }^{17}$ and the presence of TFPI in plasma will also influence measurement of TF activity in whole plasma. Nieuwland et al. ${ }^{16}$ measured TF activity on microparticles isolated from plasma, but this assay has not been used to assess TF activity in ACS patients. Giesen et al. ${ }^{14}$ stressed the concept of a physiological role for blood-borne $T F$, and were able to extract active TF from plasma of healthy subjects. Also, a chromogenic assay for measurement of TF activity in plasma has been described ${ }^{18}$, but this method requires prior isolation of the euglobulin fraction. Using a clotting assay, Butenas et al. ${ }^{19}$ recently concluded that the concentration of TF activity in non-cytokine stimulated blood from healthy individuals cannot exceed $20 \mathrm{fM}$. None of these methods allowed direct comparison of total plasma TF antigen and TF activity.

Therefore, the first aim of this study was to develop a capture assay for TF activity, applying the same high-affinity anti-TF antibody as used in a new ELISA for TF antigen, and quantitatively compare TF antigen and TF activity plasma levels in early-hospitalized patients with chest pain.

Protein markers of myocardial injury are commonly used in the diagnosis of ACS but even for the earliest marker of cardiomyocyte death, fatty acidbinding protein (FABP), it takes several hours until elevations in its plasma level become detectable ${ }^{20}$. Because coronary thrombosis occurs prior to cell death and protein release, markers of activated blood coagulation could appear earlier and thereby close this diagnostic gap. The second aim of the present work was therefore an evaluation of the diagnostic value of TF 
antigen and TF activity for ACS. Results were compared with a marker of thrombin generation $(\mathrm{F} 1+2)$ and a marker of thrombolytic activity (D-Dimer). Furthermore, the combination with FABP was evaluated. Patients with an established diagnosis of non-cardiac chest pain (NCCP) served as controls.

\section{$>$ MATERIALS AND METHODS}

\section{Patients and healthy donors}

Three groups of patients were selected from patients presenting at the Maastricht University Hospital with chest pain suggestive of acute myocardial infarction. Exclusion criteria were administration of anticoagulants or the start of thrombolytic therapy before blood sampling. The study was approved by the local Medical Ethical Committee, and patients were included after informed consent.

The first group consisted of 30 early-hospitalized patients with a wellestablished clinical diagnosis of AMI with considerable myocardial injury. This group satisfied the following selection criteria: i) plasma troponin $T(T n T)$ concentrations on admission $\left(\mathrm{TnT}_{1}\right)<0.01 \mu \mathrm{g} / \mathrm{L}$; ii) plasma $\mathrm{TnT}$ concentrations $24 \mathrm{~h}$ after admission $\left(\operatorname{TnT}_{2}\right)>2 \mu \mathrm{g} / \mathrm{L}$; and iii) admission within $6 \mathrm{~h}$ after acute onset of symptoms. The $\mathrm{TnT}_{2}$ values obtained for this group were $6.1 \pm 3.1$ $\mu \mathrm{g} / \mathrm{L}$, range: $2.2-13.7 \mu \mathrm{g} / \mathrm{L}$. The clinical diagnosis of AMI was based on chest pain of more than 30 min duration and electrocardiographic evidence, i.e., ST-segment elevation $>0.2 \mathrm{mV}$ in at least two contiguous precordial leads and/or $>0.1 \mathrm{mV}$ in at least two limb leads. Mean admission time in this group was $2.1 \pm 1.1 \mathrm{~h}$.

The second group consisted of 30 patients with a clearly established clinical diagnosis of UAP, based on angina pectoris at rest or with minimal exercise and of recent onset ( 4 weeks) and electrocardiographic evidence of myocardial ischemia, such as negative $T$ waves or ST-segment depression, not indicative of AMI. From this group 18 patients had both $\mathrm{TnT}_{1}$ and $\mathrm{TnT}_{2}$ values < $0.01 \mu \mathrm{g} / \mathrm{L}$. The remaining 12 patients showed signs of minor myocardial injury, as apparent from their $\mathrm{TnT}_{1}$ or $\mathrm{TnT}_{2}$ values. For these 12 patients $\mathrm{TnT}_{1}$ values were $0.06 \pm 0.06 \mu \mathrm{g} / \mathrm{L}$, range: $0.02-0.20 \mu \mathrm{g} / \mathrm{L}$ and $\mathrm{TnT}_{2}$ values were $0.07 \pm$ $0.06 \mu \mathrm{g} / \mathrm{L}$, range: $0.02-0.24 \mu \mathrm{g} / \mathrm{L}$.

The third group consisted of 30 patients with an established clinical diagnosis of non-cardiac chest pain (NCCP), and served as controls. For all patients, $\mathrm{TnT}_{1}$ values were $<0.01 \mu \mathrm{g} / \mathrm{L}$. For 22 patients $\mathrm{TnT}_{2}$ values were also $<0.01 \mu \mathrm{g} / \mathrm{L}$, while for the remaining 8 patients $\mathrm{TnT}_{2}$ values were not determined because they were sent home. 
After informed consent, venous blood samples were also taken from 20 healthy donors of the Sanquin Bloodtransfusion Service, Maastricht, 11 men and 9 women with a median age of $43(15-64)$ years.

\section{Blood sampling and preparation of plasma}

Venous blood samples were collected on admission, and $24 \pm 6 \mathrm{~h}$ thereafter, in Vacutainer glass tubes containing $3.2 \%$ sodium citrate. In order to prevent puncture artefacts, blood samples of ACS patients were taken after blood collection for routine purposes and before any medication was administered. Similarly, blood samples of healthy donors were obtained after donation of $500 \mathrm{ml}$ of blood. Plasma, obtained by routine centrifugation for 6 min at $2500 \mathrm{~g}$ at room temperature, was immediately aliquoted and stored at $-80^{\circ} \mathrm{C}$.

\section{Tissue factor antigen assay (ELISA)}

High-affinity, non-competing, monoclonal anti-human TF antibodies CLB/TF-5 and CLB/TF-1, and high performance ELISA buffer (HPE), were obtained from Sanquin Research, Amsterdam, the Netherlands. Biotinylation of CLB/TF-1 was performed with EZ Link Sulpho-NHS-LC biotin of Pierce and a biotin:antibody ratio of $600: 1$. Nunc immunoplates were coated overnight at $4^{\circ} \mathrm{C}$ with $5 \mu \mathrm{g} / \mathrm{mL}$ capture antibody CLB/TF- 5 in $100 \mathrm{mM}$ sodium carbonate, $\mathrm{pH}$ 9.6. Plasma was diluted 5 -fold in HPE buffer with 1 vol\% Triton, and $100 \mu \mathrm{L}$ samples were incubated with $55 \mathrm{ng}$ of biotinylated CLB/TF-1 antibody for $2 \mathrm{~h}$ at room temperature on a shaker. After washing 5 times with phosphatebuffered saline, containing 0.2 vol\% Tween-20, $100 \mu \mathrm{L}$ of $0.1 \mu \mathrm{g} / \mathrm{mL}$ poly-HRP conjugated Streptavidin (Sanquin Research) was added and incubated for another 20 min. After washing again, TMB substrate was added and after 15 $20 \mathrm{~min}$ the reaction was stopped by the addition of sulfuric acid. The optical density at $450 \mathrm{~nm}$ was read on a microplate reader, using recombinant soluble human TF as calibrator. Intra- and inter-assay imprecision of a control plasma were $2.6 \%$ and $13.3 \%$, respectively $(n=8)$. The detection limit, defined as the 99 percentile of blank values, was $40 \mathrm{fM}(n=10)$. Normal values found in the 20 healthy donors were $2.5(1.0-9.3) \mathrm{pM}$.

\section{Tissue factor activity assay}

The TF activity assay was adlapted from Giesen et al. ${ }^{14}$. As in this assay, and in an assay based on it ${ }^{21}$, we used a 3-step capture procedure. In contrast to these earlier assays, however, the present assay did not require timeconsuming detergent dialysis. In the first step, TF was extracted from plasma in 1 vol\% Triton by CLB/TF1 antibody, covalently coupled to Affigel-15 beads (Bio-Rad Laboratories). In the second step, TF was eluted from the beads and incorporated into phospholipid-glucoside micelles. Elution was performed at 
pH 2.5 in $100 \mathrm{mM}$ glycine- $\mathrm{HCl}$ containing $25 \mathrm{mM}$ glucoside (n-octyl-B-Dglucopyranoside from ICN Biomedicals $I n c$ ) and $50 \mathrm{mM}$ phospholipids (20\% DOPS/80\% DOPC from Avanti Polar-Lipids Inc). The gel was immediately removed by centrifugation and the mixture was neutralised with $1 \mathrm{M} \mathrm{Tris-HCl}$, $\mathrm{pH}$ 9.0. In the third and final step, factor $\mathrm{X}$-converting activity was measured. To this end, the samples were incubated for $7 \mathrm{~min}$ at $37^{\circ} \mathrm{C}$ with $1 \mathrm{nM}$ human recombinant factor VIla (Novo Nordisk), $5 \mathrm{mM} \mathrm{CaCl} 2$ and $6 \mu \mathrm{M}$ of sonicated phospholipid vesicles. Factor $X$ activation was then initiated by the addition of $150 \mathrm{nM}$ bovine factor $X$. Four samples were taken from the mixture at $6 \mathrm{~min}$ intervals and transferred to microtiter plate wells containing EDTA, which terminated factor Xa production. Finally, factor Xa activity was measured by

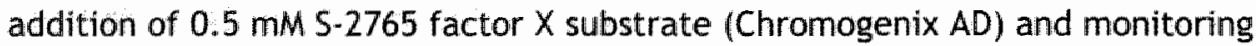
the optical density $(405 \mathrm{~nm})$ at $37^{\circ} \mathrm{C}$ on a plate reader. Recombinant fulllength human TF (Calbiochem) was used as activity calibrator. Activity calibrator samples containing $0,3,6$ and $12 \mathrm{pM}$ of active TF (see below) in buffer underwent the same procedures as the plasma samples. Intra- and inter-assay imprecision of a control plasma were $8.5 \%$ and $21.4 \%$, respectively $(n=8)$. The detection limit of the assay was $80 \mathrm{fM}(n=10)$. Normal values found in the 20 healthy donors were $2.0(1.3-4.2) \mathrm{pM}$.

\section{Quantitative comparison of TF antigen and TF activity}

It was checked that the soluble TF preparation (residues 1-219; $\mathrm{Mr}=26.8$ $\mathrm{kD}$ ) used as the calibrator in the TF ELISA was $>98 \%$ antigenic (data not shown). For the lipidated full-length TF used for the activity calibrator, the percentage of active protein was estimated by saturation of a small amount of factor VIla with excess calibrator. From the maximal activity (factor $X$ conversion rate) obtained, a catalytic constant $k_{\text {cat }}=1.9 \pm 0.2 \mathrm{~s}^{-1}$ of the TF. VIla complex was calculated. Subsequently, a small amount of calibrator was saturated with excess factor VIla and, knowing $k_{\text {cat, }}$ the maximal activity obtained indicated that $15.3 \pm 0.8 \%(n=3)$ of total protein consisted of active TF. Using this correction, both the antigen calibrator and the activity calibrator could be expressed in molar amounts of TF and thus allowed quantitative comparison.

\section{Additional assays}

Commercial immunoassays were used for measurement of the plasma concentrations of $\mathrm{TnT}$ (Roche Diagnostics, $\mathrm{GmbH}$ ), prothrombin fragment $1+2$ $(F 1+2)$, and D-Dimer (respectively Enzygnost F1+2 and D-Dimer Plus, Dade Behring, Marburg, Germany). Plasma FABP concentrations were determined as described by Wodzig et al. ${ }^{22}$. Upper limits of normal were $0.01 \mu \mathrm{g} / \mathrm{L}$ for $\mathrm{TnT}$, $1.1 \mathrm{nM}$ for $\mathrm{F} 1+2,250 \mu \mathrm{g} / \mathrm{L}$ for D-Dimer, and $6 \mu \mathrm{g} / \mathrm{L}$ for FABP. 


\section{Statistical analysis}

Statistical analyses were performed using SPSS version 11.0.1, SPSS Inc., Chicago, IL, USA. Values are presented as mean \pm SD or, for non-Gaussian distributions, as medians with total range between brackets. Differences between AMI, UAP and NCCP were evaluated after logarithmic transformation by one-way ANOVA followed by Tukey's post test. Differences between groups were tested with the Mann-Whitney rank test or, when measured in the same patients, by the paired Wilcoxon test. Spearman coefficients of correlation were calculated for non-Gaussian distributed values.

Predictive models for disease (ACS vs. NCCP or AMI vs. non-AMI) were constructed as described in De Groot et al. ${ }^{23}$. In these models, the log odds of the probability of disease $(q)$ is expressed as a linear function of the (log transformed) plasma concentrations of several markers: $\log (q /(1-q))=B_{0}+B_{1}$ $\log [F A B P]+B_{2} \log [T F$ antigen $]+B_{3} \log [F 1+2]$. Markers contributing significantly to correct prediction of disease were identified by stepwise logistic regression. Estimates for $B_{0}, B_{1}, B_{2}$, and $B_{3}$ were obtained and for each case the estimated probability of disease was calculated. The predictive value of a combination of parameters could thus be evaluated by standard ROC analysis. ROC curves were drawn and fitted with GraphPad Prism, version 4.00 for Windows, GraphPad Software, San Diego, CA. Areas under the ROC curves (AUC) were calculated to estimate the discriminative capacity of TF antigen, TF activity , F1+2, D-Dimer, FABP, and the combination of FABP, TF antigen and $F 1+2$. The significance of differences in areas under the ROC curve (AUC) values was tested with the method of Hanley and MCNeill ${ }^{24}$. A probability of $p<0.05$ was considered to be statistically significant.

\section{RESULTS}

\section{Patient characteristics}

Clinical data of the selected patients are shown in Table 1. The groups were similar in age, cardiovascular history and risk factors. None of the NCCP patients was known with a history of diabetes. None of the AMI patients had a previous history of UAP, and few of this group underwent PTCA or CABG. For the AMI patients, elevated concentrations of the coagulation markers were not related to shorter admission delays.

\section{Plasma TF antigen and TF activity in patients with chest pain}

Plasma from one NCCP patient showed outlying values for both TF antigen (296 pM) and FABP $(64 \mu \mathrm{g} / \mathrm{L})$, suggesting the presence of human anti-mouse antibodies (HAMAs) in this patient ${ }^{25}$. Data from this patient were excluded from the analysis. Figure 1 presents plasma TF antigen and TF activity 
concentrations in the admission samples of the three patient groups (AM), UAP, NCCP) and in the summed "ACS" (= AMI or LAP) and "no-AMl" (= UAP or NCCP) groups. Numerical values and statistical evaluation of these results are presented in Table $\mathbf{Z}$.

In all three patient groups, and also in healthy donors (see Methods), the concentration of TF antigen was 20-30\% higher than the concentration of TF activity. These differences were statistically significant in ACS patients $(p=0.006)$ as well as in NCCP patients $(p=0.003)$, but not in healthy donors $(p=0.33)$. Even when significant, however, these differences were small, and most plasma TF circulated in potentially active form. Thus, the median value of $1.9(0.3-4.6) \mathrm{pM}$ for TF activity in all 89 patients was $76 \%$ of the median value of $2.5(1.1-14.8) \mathrm{pM}$ for TF antigen.

Table 2 also shows that TF antigen is significantly increased in ACS patients if compared to chest pain controls. However, the difference was small and was not significant when compared to healthy donors.

Since the CLB/TF-1 antibody was non-inhibitory for TF activity, plasma TF activity could also be determined with the TF molecules still bound to the Affigel beads in their in vivo proteo-lipid matrix. For these measurements, the first capture step of the activity assay was performed in the absence of Triton in order to keep the in vivo matrix intact, and non-bound plasma proteins were washed away with buffered saline. Samples for the measurement of TF activity were then taken from end-over-end rotating sample tubes, to prevent sedimentation of Affigelbound-TF.
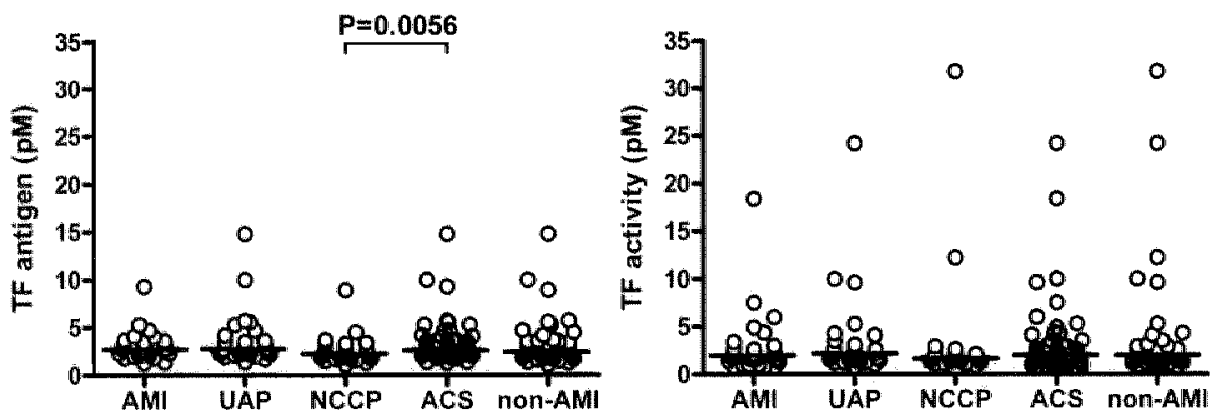

Figure 1. TF antigen (left panel) and TF activity (right panel) in patients with chest pain. Individual walues with medians are indicated for patients with AMI (acute myocardial infarction), UAP (unstable angina pectoris), NCCP (nom-cardiac chest pain), ACS (acute coronary syndromes, that is, Alyl or UAP), and non $A M I$ (UAP of NCCP). TF antigen was significantly higher than TF activity in patients with $A C S$ ( $\mathrm{P}=0.006$ ), as well as in NCCP patients ( $\mathrm{p}=0.003$ ). As indicated, TF antigen, but not TF activity, was significantly higher in ACS than in $\mathrm{NCCP}$. 
Table 1. Patient characteristics

\begin{tabular}{lccc}
\hline & $\begin{array}{c}\text { AMM } \\
(n=30)\end{array}$ & $\begin{array}{c}\text { UAP } \\
(n=30)\end{array}$ & $\begin{array}{c}\text { NCCP } \\
(n=30)\end{array}$ \\
\hline Age (yrs): median range) & $64(35-85)$ & $67(35-87)$ & $60(40-83)$ \\
Sex (Men/Women) & $22 / 8$ & $15 / 15$ & $47 / 13$ \\
Cardiovascular history: & & & \\
$\quad$ AMI & 6 & 6 & 8 \\
UAP & 0 & 8 & 4 \\
PTCA* & 4 & 8 & 4 \\
CABG* & 1 & 7 & 4 \\
Risk factors: & & & 9 \\
Family history with ACS & 16 & 12 & 0 \\
Diabetes & 4 & 7 & 10 \\
Hypercholesterolaemia & 8 & 9 & 9 \\
Hypertension & 7 & 8 & 9 \\
Smoking & 13 & 8 & \\
\hline
\end{tabular}

"CABG, coronary artery bypass grafting; PTCA, percutaneous transluminal coronary angioplasty.

No TF activity could be detected in any of the samples. Similar experiments with the activity calibrator produced activities of $52 \pm 8 \%(n=6)$ of the original activity. Thus, although the in vivo TF activity could have been partially inhibited by the binding to Affigel beads, possibly due to diffusion limitation, it should still have been easily detectable. It is concluded that although most plasma TF circulates in a potentially functional state, its activity is totally blocked in its in vivo matrix, independent of the patient's history.

Although TF antigen in ACS patients was slightly, but significantly, higher (+23\%) than in NCCP patients, this effect was not observed for TF activity. As discussed below however, this elevation of TF antigen was insufficient for a significant contribution to ACS diagnosis.

Figure 2 presents the correlation between plasma concentrations of TF antigen and TF activity in all ACS patients. Spearman correlation coefficients were $0.45(p<0.0001)$ and $0.54(p<0.0001)$ for the left and for the right panel, respectively, and the best fit linear relation in the right panel was: $T F_{a c t}=$ $0.49 \mathrm{TF}_{\text {ant }}+0.66$. Five outlying activities are apparent in the left figure but these patients were distributed over all patient groups, that is, NCCP $(n=2)$, $\operatorname{UAP}(n=2)$ and $\operatorname{AMI}(n=1)$. 

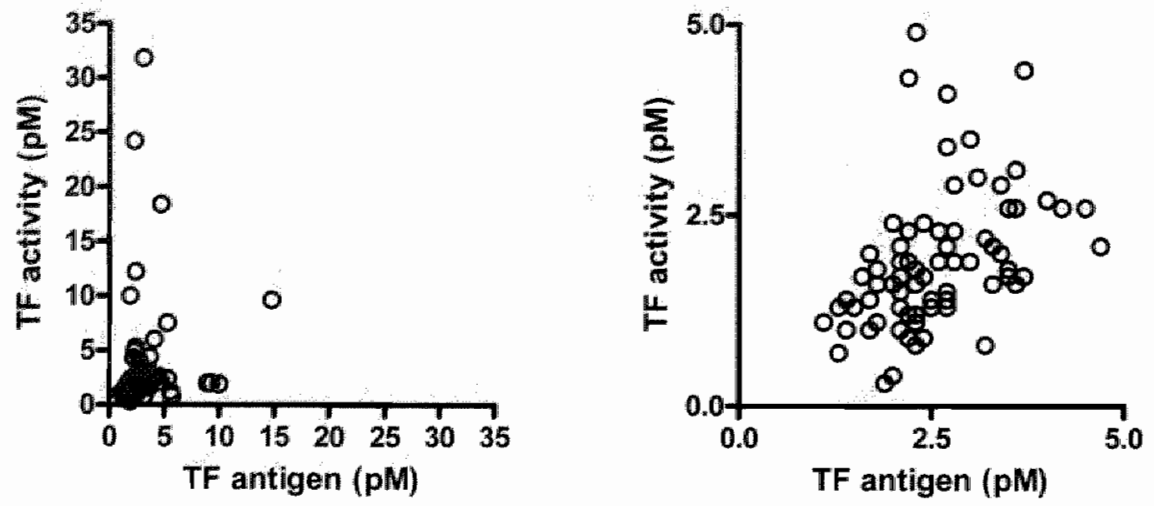

Flgure 2. Scatter pots of TF antigen versus TF activity in patients with chest pain. The left panel includes five outlying values, which are omitted from the right panel. Spearman correlation coefficients were 0.45 $(p<0.0001)$ and $0.54(p<0.0001)$ for the left and right panel, respectively, and the best fit linear relation in the right panel was:" $\mathrm{TF}_{\text {awc }}=0.49 \mathrm{TF}_{\mathrm{ant}}$ it 0.66 .
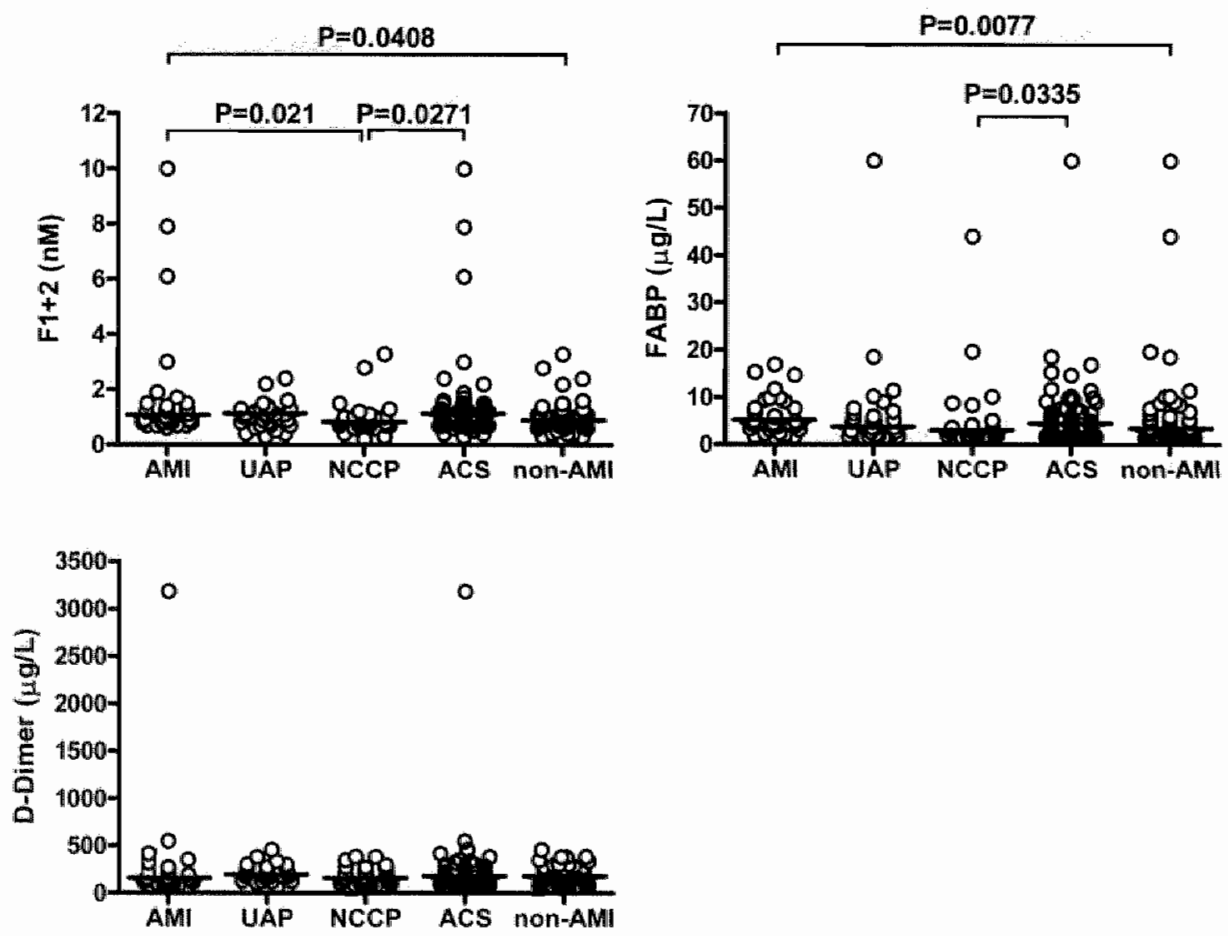

Figure 3. Plasma concentrations of F1+2, D Dimer and FABP in patients with chest pain. Significance of differences is indicated. No significant differences between the groups were abserved for D-Dimer, and no marker was able to discriminate between AMI and UAP. 
Other coagulation markers and FABP in plasma from patients with chest pain

Due to hemolytic plasma, F1+2 values for one UAP patient, and D-Dimer values for one UAP patient and two AMI patients were excluded from analysis. Figure 3 shows plasma concentrations of $F 1+2, D$-Dimer and FABP for the various patient groups. $\mathrm{F} 1+2$ and $\mathrm{FABP}$ levels were significantly higher in $A C S$ patients than in NCCP patients, and also significantly higher in AMI patients than in non-AMI patients. In addition, $F 1+2$ levels were higher in AMI patients than in NCCP patients. No significant differences between the groups were observed for D-Dimer, and no marker was able to discriminate between AMI and UAP.

Table 2. Median marker concentrations, with range, in patients with chest pain

\begin{tabular}{cccccc}
\hline & AMI & UAP & NCCP & $\begin{array}{c}\text { ACS } \\
\text { (AMI or UAP) }\end{array}$ & $\begin{array}{c}\text { non-AMI } \\
\text { (UAP or NCCP) }\end{array}$ \\
\hline TF antigen (pM) & 2.8 & 2.7 & 2.2 & $2.7^{*}$ & 2.4 \\
& $(1.3-9.3)$ & $(1.4-14.8)$ & $(1.1-8.9)$ & $(1.3-14.8)$ & $(1.1-14.8)$ \\
TF activity (PM) & 2.0 & 2.2 & 1.7 & 2.0 & 1.9 \\
& $(0.4-18.4)$ & $(0.8-24.2)$ & $(0.3-31.8)$ & $(0.4-24.2)$ & $(0.3-31.8)$ \\
F1+2 (nM) & $1.1^{* .1}$ & 1.1 & 0.8 & $1.1^{*}$ & 0.9 \\
& $(0.6-10.0)$ & $(0.3-2.4)$ & $(0.2-3.3)$ & $(0.3-10.0)$ & $(0.2-3.3)$ \\
D-Dimer $(\mu \mathrm{g} / \mathrm{L})$ & 143 & 190 & 152 & 168 & 172 \\
& $(50-3186)$ & $(50-458)$ & $(59-358)$ & $(50-3186)$ & $(50-458)$ \\
FABP $(\mu \mathrm{g} / \mathrm{L})$ & $4.6^{\dagger}$ & 3.6 & 2.9 & $4.4^{*}$ & 3.1 \\
& $(1.5-16.9)$ & $(1.5-60.0)$ & $(1.5-44.0)$ & $(1.5-60.0)$ & $(1.5-60.0)$ \\
\hline
\end{tabular}

$*$ = statistically significant from the NCCP group; $+=$ statistically signifficant from the non-AMI group.

Table 3. Areas under ROC curves (AUC)

\begin{tabular}{lcccccc}
\hline & TF antigen & TF activity & F1+2 & D-Dimer & FABP & $\begin{array}{c}\text { TF antigen * } \\
\text { F1+2 + FABP }\end{array}$ \\
\hline AMI vs NCCP & 0.674 & 0.558 & 0.674 & 0.507 & 0.707 & - \\
UAP ws NCCP & 0.676 & 0.626 & 0.614 & 0.591 & 0.573 & - \\
ACS vs NCCP & 0.675 & 0.592 & 0.645 & 0.550 & 0.640 & 0.705 \\
AMI vs UAP & 0.502 & 0.562 & 0.578 & 0.596 & 0.609 & - \\
AMI vs non-AMI & 0.586 & 0.502 & 0.627 & 0.544 & 0.657 & 0.680 \\
\hline
\end{tabular}




\section{Diagnostic performance of coagulation markers, FABP and their combination}

As shown in Figures 1 and 3 , TF antigen, F1+2 and FABP displayed diagnostic potential because these markers showed significantly higher values in ACS patients than in controls. On the other hand, all three markers show considerable overlap between both groups, resulting in a lack of discriminative power as shown below. Pearson coefficients for the correlation between these markers were low, that is, 0.07 for TF antigen versus $F 1+2$, 0.10 for TF antigen versus $F A B P$, and 0.12 for $F A B P$ versus $F 1+2$, indicating that elevated plasma levels for one marker identified different patients than for the other. This suggests combined use of these markers and the logistic regression model for their combination resulted in $B_{0}=-1.134, B_{1}=0.311, B_{2}=$ 1.492 and $B_{3}=0.872$ for discrimination of ACS from NCCP. Similarly, values of $B_{0}=-1.660, B_{1}=0.423, B_{2}=0.254$ and $B_{3}=0.977$ were found for discrimination of AMI from non-AMI. ROC curves for the various markers and the combination are shown in Figure 4 with the AUCs presented in Table 3.

ROC-Curves ACS VS NCCP

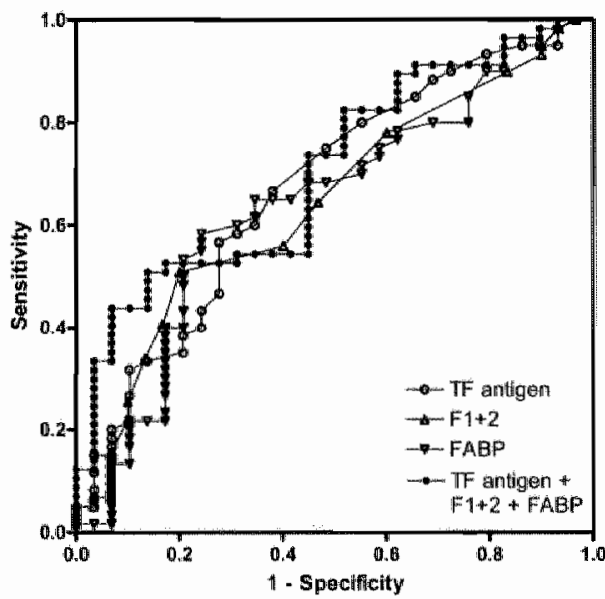

ROC-curvers AMI vs mon-AMI

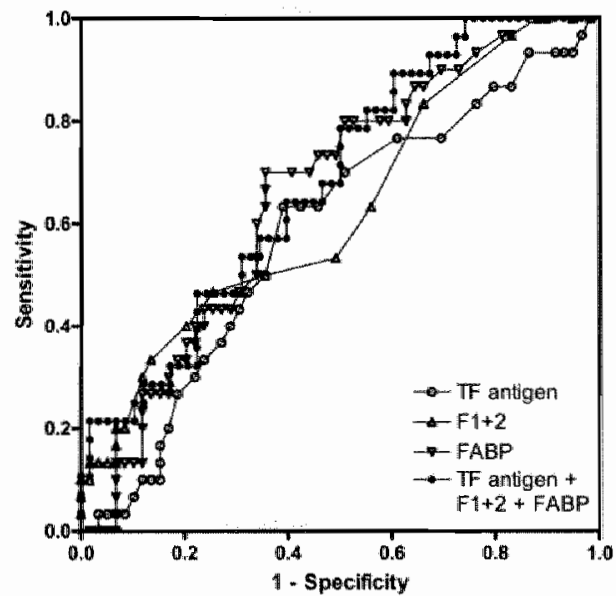

Figure 4. ROC curves for the various markers and their combination. Although the combined model performed stightly better for discrimination of ACS from NCCP and AMI from nom-AMI, the differences were not significant. It follows from this figure that none of these markers, nor their combination, allows reliable diagnosis of ACS or AMI in these very early-hospitalized patients. 
Although the combined model performed slightly better for discrimination of ACS from NCCP and AMI from non-AMI, the differences were not significant. In order to have discriminative power, a marker should have a high specificity as well as a high sensitivity, but it follows from Figure 4 that for about equal values of these two parameters they never exceeded values of about $60 \%$. It is concluded that none of these markers, or their combination, allows reliable diagnosis of ACS or AMI in these very early-hospitalized patients.

\section{DISCUSSION}

Using a variety of laboratory and commercial ELISAs, plasma TF antigen concentrations in citrated plasma have been reported to be elevated after UAP ${ }^{7-10}$ and after $A M I^{11-13}$. Elevations as reported in these studies were 230$260 \mathrm{pg} / \mathrm{mL}$ in ACS patients, versus $140-180 \mathrm{pg} / \mathrm{mL}$ in healthy controls.

Because the TF preparations as used in the various assay calibrators of these studies were variable, reported values for plasma TF antigen concentrations should preferably be compared in moles per liter, rather than in grams per liter. Also, averages, rather than medians, have usually been reported. The median values of $2.8 \mathrm{pM}, 2.7 \mathrm{pM}$ and $2.2 \mathrm{pM}$, as found in the present study for plasma TF antigen in AMI, UAP and NCCP, corresponded to mean values of $3.1 \mathrm{pM}, 3.6 \mathrm{pM}$ and $2.6 \mathrm{pM}$. Using a value of $47 \mathrm{kD}$ for the molecular mass of glycosylated, full-length $\mathrm{TF}$, the latter values correspond to 146, 169 and $122 \mathrm{pg} / \mathrm{mL}$, which is in the range of earlier reported concentrations in healthy controls. We found a modest but significant (23\%) elevation of plasma TF antigen for the total ACS group, compared to NCCP, but compared to the healthy donors the elevation was only $8 \%$ and no longer significant. This result is more in agreement with a recent study ${ }^{26}$ reporting normal TF antigen concentrations after AMI and UAP and the difference with the earlier quoted study by Falciani et al. ", using the same commercial TF assay, could possibly be explained by a recent update of this assay. Also, even accepting the significance of this difference with the NCCP group - a more valid control group than healthy donors - TF antigen elevations in the ACS group did not allow a significant contribution to ACS diagnosis in individual patients. As further discussed below, the finding that the bulk of plasma TF circulates as (functionally) intact molecules also explains why the various antibodies used in the literature, recognizing a variety of epitopes, reported roughly similar amounts of plasma TF antigen.

Most plasma TF antigen was found to be in potentially active form (Table 2 ), but this finding could be an artefact when the capture CLB/TF-1 antibody, also used in the ELISA, would only recognise a limited (potentially active) fraction of plasma TF. However, this possibility is excluded by the mentioned 
quantitative agreement between the TF antigen concentrations found in the present study and those reported in the literature for a variety of ELISAs. Apparently, the bulk of plasma TF is protected from the proteolytic fragmentation demonstrated for circulating tissue proteins like creatine kinase and enolase ${ }^{27}$, or troponin $T^{28}$. Due to the lack of a membrane-binding region, soluble TF has only a few percent of the procoagulant activity of lipidated full-length $\mathrm{TF}^{29}$, and the same is true for the alternatively spliced human TF variant (ashTF) recently found by Bogdanov et al. ${ }^{30}$. The TF antibodies used in the ELISA in the present study were raised against soluble human TF and will recognise ashTF. Therefore, the 20-30\% excess of TF antigen over TF activity could consist of ashTF, in agreement with the reported ashTF fraction of $18 / 61$ or $30 \%$ of total plasma TF antigen ${ }^{30}$.

In active form, only a small fraction of the 2-3 pM of potentially active TF could cause acute in vitro clotting of plasma ${ }^{19,31}$, and this implies that the procoagulant potential of plasma TF must be effectively inhibited in vivo. In the present study this was confirmed by the absence of any activity for plasma TF when left in its in vivo matrix. Considering the detection limit of our activity assay this would imply less than $80 \mathrm{fM}$ of active TF in plasma. This finding confirms a recent report of Butenas et al. ${ }^{19}$ who studied the effects on clotting time of addition of exogenous TF and an inhibitory anti-TF antibody to blood and plasma from healthy individuals. It was concluded that the in vivo concentration of active TF cannot exceed $20 \mathrm{fM}$, and it is interesting to note this agreement between direct measurement of plasma TF activity and measurements of physiological clotting times.

The activity assay as developed in this study had a considerable interassay variation of $21 \%$ (see Methods), which was probably caused by the use of the high-affinity CLB/TF1 antibody in the first capture step. Such high affinity hampers the complete release of TF from the Affigel beads during the elution step. On the other hand, high-affinity antibodies were required for a sensitive TF antigen assay and, in order to preserve comparability of the two assays, the same antibody was used as the capture antibody in the activity assay.

Compared to NCCP, elevated plasma F1+2 concentrations were found in $A C S$ and AMl patients. Furthermore, F1+2 was able to discriminate between $A M I$ and non-AMI. These findings are in agreement with studies reporting elevated plasma levels of $\mathrm{F} 1+2$ in the acute phase of patients with $A M \mathrm{II}^{32,33}$ and normal levels in UAP ${ }^{32}$ compared with NCCP. Our results are in contrast with a study reporting elevated F1+2 levels in UAP compared with NCCP ${ }^{8}$, and with a study reporting diagnostic power of D-Dimer in patients with chest pain 34.

We did not find any marker that was able to discriminate between AMI and UAP, and this remained true when, in a separate analysis, UAP patients with slightly elevated TnT values, indicative of minor myocardial necrosis, 
were considered as AMI patients. This is not surprising because the pathogenesis of AMI and UAP is thought to be similar, namely, rupture or fissuring of an unstable plaque followed by the formation of a superseding thrombus, thereby (partially) occluding a coronary artery. In addition to the coagulation markers, we measured plasma FABP levels as an early marker of heart muscle necrosis. We found increased FABP concentrations in ACS patients compared with NCCP, and AMI compared with non-AMI, in agreement with earlier studies ${ }^{35}$.

Detection of activated coagulation in ACS patients could be hampered either by insufficient elution of activation markers into the systemic circulation, or by rapid clearance of the coagulation markers. Elevated levels on admission could therefore reflect persistent activation, or repeated ischemic episodes, rather than a single acute coronary event. These factors may reduce sensitivity and specificity of such markers and could explain the discrepancies in the literature.

With respect to the state of plasma TF, measured concentrations of plasma TF antigen and TF activity were not increased by addition of detergent (Triton) to the plasma during the first capture step. Apparently, all TF present in plasma was exposed. In contrast, recovery of the activity calibrator from plasma decreased for detergent concentrations below 1 vol\%, and this concentration of Triton was therefore used in the assays (see Methods). This finding suggests that TF incorporated in a procoagulant matrix, like in the activity calibrator, may become hidden, or "encrypted", in plasma. This could also explain why no detergent is needed for the capture of endogenous TF from plasma, because normal plasma contains only trace amounts of procoagulant lipid ${ }^{36}$. However, TF released by a freshly ruptured plaque could still be embedded in procoagulant lipid and to measure such activity we used Triton in our assays.

\section{CONCLUSIONS}

In conclusion, using new and sensitive assays, the present study provides the first quantitative comparison of TF antigen and TF activity in plasma. It is shown that in healthy donors and ACS patients $70-80 \%$ of plasma TF antigen consists of functionally intact molecules, which upon activation could cause rapid thrombosis. This finding suggests a possible physiological role of plasma. $T F$, in addition to vascular wall-TF, as has recently been discussed ${ }^{37}$.

It is also shown that all plasma TF is exposed, but is totally inactive in its in vivo matrix. This is probably caused by the lack of procoagulant phospholipid in plasma, and this assumption is supported by the finding that 
TF added to plasma in a procoagulant matrix required detergent to be quantitatively extracted.

In contrast to reports in the literature, TF activity in ACS patients was found to be unchanged, and plasma TF antigen only marginally elevated, compared to NCCP patients. Incorporation of TF antigen into a panel of diagnostic markers for ACS, containing also $F 1+2$ and FABP, did not significantly improve early diagnosis.

\section{$>$ ACKNOWLEDGEMENTS}

The authors would like to thank Prof. J. Morrissey, University of Illinois, for providing the recombinant soluble TF. We also thank Mr. R. van Oerle, Department of Biochemistry, for measurement of D-Dimer, and Dr. M. Pelsers, Department of Molecular Genetics, for performing FABP measurements. Dr. A. Muijtjens and Mrs. M.L. Mullers-Boumans are acknowledged for expert assistance with the statistical analyses. Finally, a special word of thanks goes out to Prof. H. Crijns, Ms. M. Baggen and all medical doctors and assistants at the Cardiology Department of the Maastricht University Hospital for including the patients. This study was supported by research grants 98.063 and 2002B189 from the Netherlands Heart Foundation. Jan F.C. Glatz is Netherlands Heart Foundation Professor. 
1. Fuster V. Lewis A. Conner Memorial Lecture. Mechanisms leading to myocardial infarction: insights from studies of vascular biology. Circulation. 1994; $90: 2126$. 46.

2. Topal EJ, Yadav JS. Recognition of the importance of embolization in atherosclerotic vascular disease. Circulation. 2000; 101: 570 80 .

3. Albrecht $S$, Kotzsch $M_{n}$ Siegert $G$, Luther $T$, Grossmann $H$, Grosser $M$, Muller $M$. Detection of circulating tissue factor and factor VII in a normal population. Thromb Haemost. 1996;75:772-7.

4. Francis $\mathrm{JL}$, Carvalho $M$, Francis DA. The clinicall value of tissue factor assays. Blood Coagul Fibrinolysis. 1995;6 Suppl 1:S37-44.

5. Fareed J, Callas DD, Hoppensteadt D, Bermes EW, Jr. Tissue factor antigen levels in various biological fluids. Blood Coagul Fibrinolysis. 1995;6 Suppl 1:S32-6.

6. Koyama T, Nishida K, Ohdama S, Sawada M, Murakami N, Hirosawa S, Kuriyama R, Matsuzawa $K$, Hasegawa $R$, Aoki $\mathbb{N}$. Determination of plasma tissue factor antigen and its clinical significance. Br J Haematol. 1994;87:343-7.

7. Misumi $K$, Ogawa $H$, Yasue $H$, Soejima $H_{*}$ Suefuji $H$, Nishiyama $K$, Takazoe $K$, Kugiyama K, Tsuji I, Kumeda K, Nakamura S. Comparison of plasma tissue factor levels in unstable and stable angina pectoris. Am $J$ Cardiol. 1998;81:22-6.

8. Soejima $H$, Ogawa $H$, Yasue $H$, Kaikita $K$, Nishiyama $K$, Misumi $K$, Takazoe $K$, Miyao $Y$, Yoshimura M, Kugiyama K, Nakamura S, Tsuji 1, Kumeda K. Heightened tissue factor associated with tissue factor pathway inhibitor and prognosis in patients with unstable angina. Circulation. 1999;99:2908-13.

9. Falciani M, Gori AM, Fedi S, Chiarugi L, Simonetti I, Dabizzi RP, Prisco D, Pepe G, Abbate R, Gensini GF, Neri Serneri GG. Elevated tissue factor and tissue factor pathway inhibitor circulating levels in ischaemic heart disease patients. Thromb Haemost. 1998;79:495-9.

10. Marco J, Ariens RA, Fajadet J, Bossi IM, Marco I, Bernies M, Romano SM, Donatelli F, Brambilla GM, Somalvico F, Mari D, Gregorini L. Effect of aspirin and ticlopidine on plasma tissue factor levels in stable and unstable angina pectoris. Am J Cardiol. 2000;85:527-31.

11. Suefuji $H$, Ogawa $H$, Yasue $H$, Kaikita $K$, Soejima $H$, Motoyama $T$, Mizuno $Y$, Oshima S, Saito T, Tsuji I, Kumeda K, Kamikubo Y, Nakamura S. Increased plasma tissue factor levels in acute myocardial infarction. Am Heart J. 1997; 13.4:253-9.

12. He $M$, Wen $Z$, He X, Xiong $S$, Liu $F, X u J, L i J$, Xie $Q$, Jian $Z$, Chen $F$, Xiao B, Pu $X_{*}$ He $S$. Observation on tissue factor pathway and some other coagulation parameters during the onset of acute cerebrocardiac thrombotic diseases. Thromb Res. 2002;107:223-8.

13. Yamamoto $N$, Ogawa $H$, Oshima $S$, Soejima $H$, Fujii $H$, Misumi $K$, Takazoe $K$, Mizuno $Y$, Noda K, Saito T, Tsuji I, Kumeda K, Nakamura S, Yasue H. The effect of 
heparin on tissue factor and tissue factor pathway inhibitor in patients with acute myocardial infarction. Int J Cardiol. 2000;75:267-74.

14. Giesen PL, Rauch U, Bohrmann B, Kling D, Roque M, Fallon JT, Badimon JJ, Himber J, Riederer MA, Nemerson $Y$. Blood-borne tissue factor: another view of thrombosis. Proc Natl Acad Sci U S A. 1999;96:2311-5.

15. Fukuda $C$, lijima $K$, Nakamura $K$. Measuring tissue factor (factor llll) activity in plasma. Clin Chem. 1989;35:1897-900.

16. Nieuwland R, Berckmans RJ, Rotteveel-Eijkman RC, Maquelin KN, Roozendaal KJ, Jansen $P G$, ten Have K, Eijsman L, Hack CE, Sturk A. Cell-derived microparticles generated in patients during cardiopulmonary bypass are highly procoagulant. Circulation. 1997;96:3534-41.

17. Goltino $P$, Ravera $A$, Ragni $M$, Ciritlo $P$, Orlando $P$, Chiariello $M$. Involvement of tissue factor pathway inhibitor in the coronary circulation of patients with acute coronary syndromes. Circulation. 2003;108:2864-69.

18. He M, Wen Z, He X, Xiong S, Liu F, Xu J, Li J, Xie Q, Jian Z, Chen F, Xiao B, Pu X, He 5 . Observation on tissue factor pathway and some other coagulation parameters during the onset of acute cerebrocardiac thrombotic diseases. Thromb Res. 2002;107:223-8.

19. Butenas S, Bouchard BA, Brummel-Ziedins KE, Parhami-Seren B, Mann KG. Tissue factor activity in whole blood. Blood. 2005;105:2764-70.

20. Glatz JFC, van der Putten RFM, Hermens WT. Fatty acid binding protein as an early plasma marker of myocardial ischemia and risk stratification. In: Cardiac Markers, ed. Alan H.B. Wu, Humana Press Inc., Totowa NJ, $2^{\text {nd }}$ ed. 2003, pp. 31937.

21. Sambola A, Osende J, Hathcock J, Degen M, Nemerson Y, Fuster V, Crandall J, Badimon JJ. Role of risk factors in the modulation of tissue factor activity and blood thrombogenicity. Circulation. 2003;107: 973-7.

22. Wodzig KW, Pelsers MM, van der Vusse GJ, Roos W, Glatz JF. One-step enzymelinked irmmunosorbent assay (ELISA) for plasma fatty acid-binding protein. Amn Clin Biochem. 1997;34 ( Pt 3):263-8.

23. De Groot MJ, Muijtjens AM, Simoons ML, Hermens WT, Glatz JF. Assessment of coronary reperfusion in patients with myocardial infarction using fatty acid binding protein concentrations in plasma. Heart. 2001;85:278-85.

24. Hanley JA, McNeil BJ. A method of comparing the areas under receiver operating characteristic curves derived from the same cases. Radiology. 1983; 148: 839-43.

25. Kricka LJ. Human anti-animal antibody interferences in immunological assays. Clin Chem. 1999;45:942-6.

26. Maly' $M$, Vojacek J, Hrabos V, Kvasnicka J, Salaji P, Durdil V. Tissue factor, tissue factor pathway inhibitor and cytoadhesive molecules in patients with an acute coronary syndrome. Physiol Res. 2003; 52: 719-28.

27. Van Landeghem AA, Soons JB, Wever RA, Mul-Steinbusch MW, Antonissen-Zijda T. Purification and determination of the modifying protein responsible for the post- 
synthetic modification of creatine kinase (EC 2.7.3.2) and enolase (EC 4.2.1.11). Clin Chim Acta. 1985;153:217-24.

28. Diris JHC, Hackeng CM, Kooman JP, Pinto YM, Hermens WTh, van Dieijen-Visser M. Impaired renal clearance explains elevated troponin $T$ fragments in hemodiallysis patients. Circulation. 2004; 109:23-5.

29. Waxman E, Ross JBA, Laue TM, Guha A, Thiruvikraman SV, Lin TC, Koningsberg $W H$, Nemerson $Y$. Tissue factor and its extracellular soluble domain: The relationship between intermolecular association with factor VIla and enzymatic activity of the complex. Biochemistry 1992; 31: 3998-4003.

30. Bogdanov $V Y$, Balasubramania $V$, Hathcock $J$, Vele $O$, Lieb $M$, Nemerson $Y$. Alternatively spliced human tissue factor: a circulating, soluble, thrombogenic protein. Nature Medicine. 2003;9:458-62.

31. Hemker HC, Giesen $P$, Al Dieri R, Regnault $V$, de Smedt $E$, Wagenvoord $R$, Lecompte $T$, Beguin $S$. Calibrated automated thrombin generation measurement in clotting plasma. Pathophysiol Haemost Thromb. 2003;33:4-15.

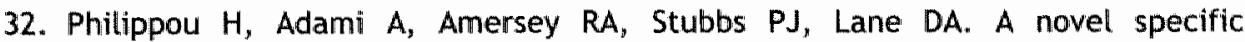
immunoassay for plasma two-chain factor Vlla: investigation of FVlla levels in normal individuals and in patients with acute coronary syndromes. Blood. 1997;89:767-75.

33. Al-Obaidi MK, Philippou H, Stubbs PJ, Adami A, Amersey R, Noble MM, Lane DA. Relationships between homocysteine, factor VIla, and thrombin generation in acute coronary syndromes. Circulation. 2000;101:372-7.

34. Bayes-Genis A, Mateo J, Santalo M, Oliver A, Guindo J, Badimon L, Martinez-Rubio A, Fontcuberta J, Schwartz RS, De Luna AB. D-Dimer is an early diagnostic marker of coronary ischemia in patients with chest pain. Am Heart J. 2000;140:379-84.

35. Glatz JFC, Haastrup B, Hermens WT, de Zwaan C, Barker J, McNeil CJ, Adams P, Lüscher $M$, Ravkilde $J$, Thygesen $K$, Kristensen $S$, Horder $M$, for the EUROCARDI Study Group. Fatty acid-binding protein and the early detection of acute myocardial infarction: The EUROCARDI Multicenter Trial (Abstract). Circulation. 1997;96 Supp| I: 215.

36. Deguchi $H$, Fernandez JA, Hackeng TM, Banka $C L$, Griffin JH. Cardiolipin is a normal component of human plasma lipoproteins. Proc Natl Acad Scl U 5 A. 2000 "97(4); $1743-8$.

37. Bauer KA. Functional tissue factor in blood? Blood. 2005; 105:2620-1. 

CHAPTER 7

GENERAL DISCUSSION 


\section{$>$ MAIN FINDINGS OF THIS THESIS}

The aims of the present studies were to develop sensitive assays for the measurement of tissue factor (TF) antigen and TF activity in plasma, to understand quantitatively the in vivo state of plasma TF activity, and to evaluate the combination of these and other markers of activated blood coagulation with fatty acid-binding protein (FABP) in the early diagnosis of patients presenting at the emergency department with chest pain suggestive of ACS. The main results presented in this thesis are:

1. Use of high-affinity monoclonal anti-TF antibodies allowed development of a sensitive ELISA for plasma TF antigen, with a detection limit of $40 \mathrm{fM}$, that is, about 6 times lower than previously reported.

2. TF antigen concentrations in plasma from healthy donors and ACS patients are 2-3 pM, roughly in agreement with earlier reported values.

3. Using this new ELISA, intra-individual variation in plasma TF antigen concentrations, as estimated from repeated measurements in patients with type 2 diabetes, proved less than 15\%, instead of estimates of > $50 \%$ for a commercial ELISA.

4. Using one of the mentioned high-affinity monoclonal anti-TF antibodies, a sensitive and rapid capture assay for plasma TF activity was developed, allowing expression of activities in absolute (molar) amounts of active protein and with a detection limit of $80 \mathrm{fM}$. In contrast to similar and earlier reported capture assays, the present assay does not involve a time-consuming dialysis step.

5. Using these new assays it was found in healthy donors, as well as in ACS patients, that the bulk ( $>75 \%$ ) of plasma TF antigen circulates in a potentially active form. The remaining $25 \%$ of TF antigen could consist of the recently reported alternatively-spliced human TF variant in plasma (ashTF).

6. Although consisting of potentially active molecules, the activity of plasma TF was found to be completely absent in its in vivo state, probably due to lack of a procoagulant lipid matrix.

7. All TF in plasma circulates in exposed form and can be captured by Affigel-bound high-affinity anti-TF antibodies.

8. Markers of activated blood coagulation do not contribute significantly to the diagnosis of patients presenting to the hospital with chest pain suggestive of ACS. 
It is widely accepted that the blood clotting system is triggered during normal hemostasis when TF, normally present on certain cell types outside the vasculature, is exposed to the blood following vascular injury". However, a novel hypothesis has been put forward in which TF present in the circulating blood may participate in hemostasis and thrombosis. Under physiological conditions, full-length TF may be mainly associated with platelets and circulating microvesicles ${ }^{2-4}$. This is probably also observed under pathological conditions in vivo, such as during myocardial infarction ${ }^{5}$. TF from monocytes, on the other hand, could play a major role in in the long-term amplification of thrombosis, whenever activating stimuli are provided by inflammation ${ }^{6}$.

In this view, microparticle-associated TF that circulates in plasma plays a significant role in hemostasis by enabling the generation of fibrin at the site of the growing thrombus ${ }^{2,7}$. These circulating, TF-containing microparticles are proposed either to contain TF in an inactive or 'encrypted' form, or to contain TF at levels that are too low to trigger clot formation unless the particles are concentrated locally (as at sites of injury). Since TF has also been found in the microvesicle-free supernatant of plasma ${ }^{6,8,9}$, it is likely that plasma also contains a soluble form of TF. However, because soluble TF is much less active as initiator of blood coagulation than full-length TF ${ }^{10}$, the microvesicle-associated-TF probably represents the potentially active form of TF in plasma.

\section{PLASMA TF ANTIGEN IN HEALTY DONORS AND IN ACS PATIENTS $\mid<$}

Previous studies generally reported TF antigen levels of $125-175 \mathrm{pg} / \mathrm{mL}$ in healthy donors (Chapter 2). Using SDS-PAGE without reduction followed by immunoblotting, Koyama et al. ${ }^{11}$ reported molecular masses of $29 \mathrm{kD}, 135 \mathrm{kD}$ and large aggregates $>200 \mathrm{kD}$ for plasma TF. They hypothesized that TF might circulate in disulphide bond linked heteromultimer or homomultimer form; the large aggregates could be lipid-associated TF. Bogdanov et al. ${ }^{9}$ recentlly identified an alternatively-spliced form of human TF (ashTF), that contains most of the extracellular domain of TF but lacks a transmembrane domain and terminates with a unique peptide sequence. AshTF is soluble, circulates in blood, exhibits some procoagulant activity when exposed to phospholipids, and is incorporated into thrombi. The amount of ashTF in human plasma was determined by ELISA, and found to be $25-30 \%$ of total TF antigen ( $n=6)$.

These studies suggest that the molecular mass of plasma TF is heterogenous. Furthermore, there is no internationally accepted calibrator for 
measurements of Tf antigen, which may result in considerable inter-study variation in plasma TF antigen levels, as evident from the above mentioned studies. Therefore, in this thesis, plasma TF antigen levels were expressed in molar amounts rather than $\mathrm{pg} / \mathrm{mL}$. Interestingly, we did not find an effect of Triton on TF antigen levels in plasma, which indicates that TF in plasma is fully exposed. Since already $0.5 \mathrm{pM}$ of active TF would cause immediate clotting ${ }^{12}$, plasma TF must indeed be effectively inactivated in vivo, as demonstrated in the present study.

A number of studies have determined plasma TF antigen levels in the acute phase in patients with unstable angina ${ }^{13-18}$ and myocardial infarction ${ }^{19 .}$ ${ }^{21}$ (Chapter 2). With the exception of the study by Marco et al. ${ }^{18}$, reporting a value of $553 \pm 91 \mathrm{pg} / \mathrm{mL}$ after UAP versus $193 \pm 95 \mathrm{pg} / \mathrm{mL}$ after stable angina pectoris (SAP), these studies reported TF antigen levels $(230-260 \mathrm{pg} / \mathrm{mL})$ that were only moderately elevated compared with control subjects (125-175 $\mathrm{pg} / \mathrm{mL}$ ). Using the same commercial ELISA as in the studies by Falciano et al. ${ }^{16}$ and Marco et al. ${ }^{18}$, the study by Malý et al. ${ }^{22}$ even reported normal TF antigen levels after AMI and UAP. Although we also found slightly elevated TF antigen levels in AMI $(146 \pm 70 \mathrm{pg} / \mathrm{mL})$ and UAP patients $(169 \pm 128 \mathrm{pg} / \mathrm{mL})$, only ACS patients as a group $(158 \pm 103 \mathrm{pg} / \mathrm{mL})$ were significantly elevated compared with non-cardiac chest-pain controls $(121 \pm 67 \mathrm{pg} / \mathrm{mL}$ ) (Chapter 6). Our results confirm a modest elevation of plasma TF antigen levels in patients with ACS, however, this effect does not allow a significant contribution to early ACS diagnosis in individual patients (see below).

\section{> | PLASMA TF ACTIVITY IN HEALTY DONORS AND IN ACS PATIENTS}

TF containing microvesicles isolated from systemic plasma from healthy donors, when present alone, have previously shown to be unable to support the cleavage of factor $X$ necessary for the initiation of coagulation ${ }^{3,23}$. In agreement with this result, we also found that TF isolated from systemic plasma of healthy donors did not generate factor Xa, when bound to the Affigel in its in vivo proteo-lipid matrix (Chapter 4). However, after incorporating TF into phospholipid-glucoside micelles, $>75 \%$ of plasma TF could be reactivated. Also, as discussed in Chapter 4, we found in both ELISA and TF activity assay that TF added to plasma in a procoagulant lipid matrix, could only be captured quantitatively from plasma in the presence of detergent, unlike native plasma TF. As a consequence, we explained the absence of TF activity in its in vivo matrix by the lack of a procoagulant phospholipid matrix. Indeed, it has been shown that only trace amounts of procoagulant PS are present in normal plasma ${ }^{24}$. However, Bauer et al. ${ }^{25}$ detected activation peptides of $I X, X$ and prothrombin $\left(F_{1+2}\right)$ in healthy donor 
plasma. These levels were decreased in patients with hereditary factor VII deficiency, but not in patients with factor XI deficiency, indicating basal in vivo thrombin formation by the TF pathway. Apparently, this aspect needs further study.

Sturk-Maquelin et al. ${ }^{8}$ studied non-cell bound TF activity in microparticles isolated from systemic and pericardial blood samples from patients undergoing cardiac injury. The fluid phase form of TF did not initlate thrombin generation. Interestingly, in pericardial samples, $45-77 \%$ of TF was microparticle-associated, and triggered factor VII-mediated thrombin generation in vitro, whereas in systemic samples, microparticles initiated thrombin formation independently of factor VII. Apparently, this was not due to lack of procoagulant phospholipids on the surface of these microparticles in the latter samples, since in an earlier study, Nieuwland et al. ${ }^{26}$ showed that about $90 \%$ of the microparticles isolated from systemic blood from these patients bound Annexin V, which is considered to indicate the presence of (procoagulant) phosphatidylserine (PS).

It is known that in acute coronary syndromes, arterial thrombosis is triggered by the rupture of atherosclerotic plaques ${ }^{27}$. Within the plaque, the lipid-rich core has been shown to be the most thrombogenic component, which contains TF, in particular in association with procoagulant microvesicles 28. Because of the small difference in TF antigen between ACS patients and healthy controls, we hypothesize that the amount of procoagulant TFmicrovesicles that is released locally into the blood is only small, and may not even be detected in systemic plasma at all, especially if the thrombus being formed in the coronary artery is occlusive.

\section{MECHANISMS OF IN VIVO TF INACTIVATION}

It has been shown that intact cells, even when expressing TF, have much lower procoagulant activity than cells that have been damaged, lysed or treated with calcium ionophore ${ }^{29}$. Although TF is present on the surface of such cells, it only becomes fully activated when the membrane properties of the cell are altered ${ }^{30,31}$. There are several potential explanations for this phenomenon of TF 'encryption'. Firstly, cells are known to restrict the distribution of aminophospholipids (such as the negatively charged phosphatidylserine) to the inner leaflet of the plasmamembrane ${ }^{32}$. Negatively charged phospholipids are required for substrate molecules such as factor $\mathrm{IX}$ or $X$ to bind to the membrane, so their sequestration limits the activity of cell surface TF. When cells are lysed, damaged or treated with calcium ionophore, this phospholipid asymmetry is lost Secondly, in some cell types, TF may associate with caveolae, which are areas of the cell surface with altered lipid 
composition 32-34. Thirdly, it has been proposed that dimerization or oligomerization of $T F$ in the membrane may reduce its activity, and that damage or lysis of cells may promote the formation of active TF monomers ${ }^{35}$.

It is not clear, however, how de-encryption of TF activity in plasma is regulated. Several studies have suggested an important role for blood cells. Under in vivo conditions, platelets are rapidly assembled with different types of leukocytes in the developing thrombus ${ }^{36}$. Moreover, platelet-leukocyte interactions were shown to support fibrin formation under different experimental conditions ${ }^{37.39}$. The results of these studies are likely to be explained by the presentation of TF in these conjugates ${ }^{4}$. While these platelet-leukocyte adhesions contribute to the increase in thrombus mass in vivo, their role in the initiation of the coagulation process has not yet been clearly demonstrated. Neutrophils (and monocytes) were found to be essential as stimulators of the functional activity of TF associated with the activated platelets and circulating microvesicles ${ }^{3}$. Further study is needed to elucidate this mechanism.

\section{> MARKERS OF COAGULATION ACTIVATION IN THE EARLY DIAGNOSIS OF ACUTE CORONARY SYNDROMES}

The ACS patients that were enrolled in the study discussed in Chapter 6 of this thesis included AMI patients that presented within $2.1 \mathrm{~h}$ (median) after onset of chest pain. Such early admitted patients were selected because markers of coagulation activation are rapidly cleared from the circulation, and thus become less useful with longer periods after the acute event. In contrast, as explained in Chapter 5, markers of myocardial necrosis are not detectable until a few hours after the acute event. Therefore, in order to establish an accurate diagnosis that is independent on the delay of the patient to the hospital, it seems useful to combine plasma markers of coagulation activation and myocardial necrosis. Surprisingly, as shown in Chapter 2 (Table 8), only a few studies have reported on the sensitivity and specificity of hemostatic markers and their combinations with markers of myocardial necrosis to detect ACS in a clinical setting.

In general, increased levels of markers with a relatively short half-life time for survival in plasma (e.g., FPA, TAT) reflect ongoing thrombosis at the time of blood sampling. Therefore, their role in diagnosing patients with chest pain seems limited, but they may be useful in identifying patients who are at an increased risk for the development of future cardiac events. In contrast, increased levels of markers with relatively longer half-life times (e.g., F1+2, $D$-Dimer) may be more successful in establishing ACS diagnosis. There is no 
information available concerning the half-life of TF (or its clearance mechanism) in plasma.

In Chapter 6 we showed that sensitivities and specificities for TF antigen, TF activity, F1+2, D-Dimer for the discrimination of ACS from non-ACS or AMI from non-AMI are low. Furthermore, evaluation of the most promising coagulation markers (TF antigen, $F 1+2$ ) in a diagnostic panel with FABP (the earliest protein marker of myocardial necrosis) did not result in a significant increase of the sensitivity and specificity.

Apart from admission time, other factors that may reduce the sensitivity of activation markers of coagulation are: (a) a relatively small thrombus may not yield detectable elution of activation markers into the systemic circulation, particularly when the vessel is already occluded; (b) experience with fibrinolytic therapy suggests that only $-50 \%$ of occlusive thrombi may be considered fibrin-rich 40,41 . Appropriate interpretation of measured marker levels requires an appreciation of potentially confounding factors. Markers of activated coagulation reflect the presence of thrombosis in any vascular bed, not necessarily in the coronary circulation. Aging, the use of certain drugs, and dysfunction of physiologic clearance may result in substantial elevations of markers of coagulation activation. For some markers in vitro artifacts during sampling are known. The cut-off level for each marker, to be used for the definition of elevations, is still largely unknown given the dissimilarities of the analytical methods used. Elevations may also occur in the absence of overt thrombosis, the so-called pre-thrombotic state.

Ultimately, we feel that the result of all these observations is reflected by the many studies that were discussed in Chapter 2, that indicate that for every coagulation marker studied: (i) plasma levels between ACS patients are only marginally increased; (ii) at least one study found no significant differences between ACS patients and control subjects; (iii) many ACS patients have normal plasma levels. Also, our study that focussed on the TF antigen and activity and a few other studies that have addressed combinations of (other) markers of coagulation activation and myocardial necrosis did not show promising results. In conclusion, markers of coagulation do not significantly contribute to the early diagnosis of ACS. 


\section{REFERENCES}

1. Morrissey $\mathrm{JH}$. Tissue factor: an enzyme cofactor and a true receptor. Thromb Haemost. 2001;86:66-74.

2. Giesen $\mathrm{PL}$, Rauch U, Bohrmann B, Kling D, Roque $M$, Fallon JT, Badimon JJ, Himber J, Riederer MA, Nemerson $Y$. Blood-borne tissue factor: another view of thrombosis. Proc Natl Acad Soi U S A. 1999;96:2311-5.

3. Muller 1, Klocke A, Allex M, Kotzsch $M$, Luther T, Morgenstern $E_{n}$ Zieseniss 5 , Zahler $S$, Preissner $K_{*}$ Engelmann B. Intravascular tissue factor initiates coagulation via circulating microvesicles and platelets. Faseb J. 2003.

4. Zillmann A, Luther T, Muller I, Kotzsch M, Spannagl M, Kauke T, Oelschlagel U, Zahler 5, Engelmanin B. Platelet-associated tissue factor contributes to the collagen-triggered activation of blood coagulation. Biochem Biophys Res Commun. 2001;281:603-9.

5. Ott I, Andrassy M, Zieglgansberger D, Geith S, Schomig A, Neumann FJ.. Regulation of monocyte procoagulant activity in acute myocardial infarction: role of tissue factor and tissue factor pathway inhibitor-1. Blood. $2001 ; 97: 3721-6$.

6. Engelmanin B, Luther T, Muller I. Intravascular tissue factor pathway--a model for rapid initiation of coagulation within the blood vessel. Thromb Haemost. 2003;89:3-8.

7. Giesen $\mathrm{PL}$, Nemerson $\mathrm{Y}$. Tissue factor on the loose. Semin Thromb Hemost. $2000 ; 26: 379-84$.

8. Sturk-Maquelin $K N$, Nieuwland $R_{*}$ Romijn FP, Eijsman L, Hack CE, Sturk A. Proand non-coagulant forms of non-cell-bound tissue factor in vivo. J Thromb Haemost. 2003;1:1920-6.

9. Bogdanov $\mathrm{V} Y$, Balasubramanian $V$, Hathcock $J$, Vele $O$, Lieb $M$, Nemerson $Y$. Alternatively spliced human tissue factor: a circulating, soluble, thrombogenic protein. Nat Med. 2003;9:458-62.

10. Waxman E, Ross JB, Laue TM, Guha A, Thiruwikraman SV, Lin TC, Konigsberg, $W H$, Nemerson $Y$. Tissue factor and its extracellular saluble domain: the relationship between intermolecular association with factor Vila and enzymatic activity of the complex. Biochemistry. 1992;31:3998-4003.

11. Koyama $T$, Nishida $K$, Ohdama $S$, Sawada $M$, Murakami $N$, Hirosawa $S$, Kuriyama $R$, Matsuzawa $K$, Hasegawa $R$, Aoki $N$. Determination of plasma tissue factor antigen and its clinical significance. Br J Haematol. 1994;87:3437.

12. Hemker $H C$, Giesen $P$, Al Dieri R, Regnault $V$, de Smedt $E$, Wagenvoord $R$, Lecompte $T$, Beguin $S$. Calibrated automated thrombin generation measurement in clotting plasma. Pathophysiol Haemost Thromb. 2003;33:415. 


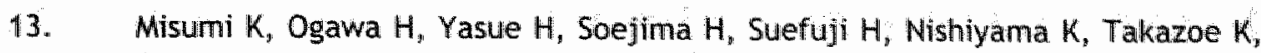
Kugiyama K, Tsuji I, Kumeda K, Nakamura S. Comparison of plasma tissue factor levels in unstable and stable angina pectoris. Am J Cardiol . 1998;81:22. 6.

14. Miyamoto $S$, Ogawa $H$, Sakamoto $T$, Soejima $H$, Takazoe $K$, Shimomura $H$, Kajjiwara $l_{x}$ Yoshimura $M$, Kugiyama $K$, Nakamura $S$, Ozaki $Y$. Platelet hyperaggregability persists even after the improvement of increased blood coagulation and impaired fibrinolysis with the stabilization of symptoms in patients with unstable angina. Int J Cardiol. 2001;80:235-42.

15. Soejima $H$, Ogawa $H$, Yasue $H$, Kaikita $K$, Nishiyama $K$, Misumi $K$, Takazoe $K$, Miyao $Y$, Yoshimura $M$, Kugiyama K, Nakamura 5, Tsuji I, Kumeda $K$. Heightened tissue factor associated with tissue factor pathway inhibitor and prognosis in patients with unstable angina. Circulation. 1999;99:2908-13.

16. Falciani M, Gori AM, Fedi S, Chiarugi L, Simonetti I, Dabizzi RP, Prisco D, Pepe G, Abbate R, Gensini GF, Neri Serneri GG. Elevated tissue factor and tissue factor pathway inhibitor circulating levels in ischaemic heart disease patients. Thromb Haemost. 1998;79:495-9.

17. Gori AM, Pepe G, Attanasio M, Falciani M, Abbate R, Prisco D, Fedi 5, Giusti B, Brunelli T, Comeglio P, Gensini GF, Neri Serneri GG. Tissue factor reduction and tissue factor pathway inhibitor release after heparin administration. Thromb Haemost. 1999;81:589-93.

18. Marco J, Ariens RA, Fajadet J, Bossi IM, Marco I, Bernies M, Romano SM, Donatelli F, Brambilla GM, Somalvico F, Mari D, Gregorini L. Effect of aspirin and ticlopidine on plasma tissue factor levels in stable and unstable angina pectoris. Am J Cardiol. 2000;85:527-31.

19. Suefuji $H$, Ogawa $H$, Yasue $H$, Kaikita $K$, Soejima $H$, Motoyama $T$, Mizuno $Y$, Oshima S, Saito T, Tsuji I, Kumeda K, Kamikubo $Y$, Nakamura S. Increased plasma tissue factor levels in acute myocardial infarction. Am Heart $J$. 1997;134:253-9.

20. He X, Wen $Z$, Xiong $S$, He $M, L i J$, He $S$. Studies on an assay for functional tissue factor pathway inhibitor antigen. Chin $\mathcal{L}$ Thromb Hemostat. 2001;7:912.

21. Yamamoto $N$, Ogawa $H$, Oshima $S$, Soejima $H$, Fujii $H$, Misumi K, Takazoe $K$, Mizuno $Y$, Noda $K$, Saito $T$, Tsuji I, Kumeda $K$, Nakamura $S$, Yasue $H$. The effect of heparin on tissue factor and tissue factor pathway inhibitor in patients with acute myocardial infarction. Int $J$ Cardiol. 2000;75:267-74.

22. Malý $M$, Vojacek J, Hrabos $V$, Kvasnicka $J$, Salaj $P$, Durdill $V$. Tissue factor, tissue factor pathway inhibitor and cytoadhesive molecules in patients with an acute coronary syndrome. Physiol Res. 2003;52:719-28.

23. Berckmans RJ, Nieuwland R, Boing AN, Romijn FP, Hack CE, Sturk A. Cellderived microparticles circulate in healthy humans and support low grade thrombin generation. Thromb Haemost. 2001;85:639-46. 
24. Deguchi $H$, Fernandez JA, Hackeng TM, Banka $C L$, Griffin JH. Cardiolipin is a normal component of human plasma lipoproteins. Proc Natl Acad Sci U 5 A. 2000;97:1743-8.

25. Bauer KA, Kass $\mathrm{BL}$, ten Cate $\mathrm{H}$, Bednarek MA, Hawiger JJ, Rosenberg RD. Detection of factor $X$ activation in humans. Blood. 1989;74:2007-15.

26. Nieuwland R, Berckmans RJ, Rotteveel-Ejjkman RC, Maquelin KN, Roozendaal

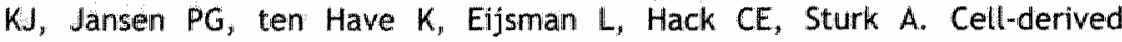
microparticles generated in patients during cardiopulmonary bypass are highty procoagulant. Circulation. 1997;96:3534-41.

27. Libby $P$. Changing concepts of atherogenesis. J Intern Med. 2000;247:349-58.

28. Mallat $Z$, Hugel B, Ohan $J$, Leseche $G$, Freyssinet JM, Tedgui $A$. Shed membrane microparticles with procoagulant potential in human atherosclerotic plaques: a role for apoptosis in plaque thrombogenicity. Circulation. 1999;99:348-53.

29. Maynard JR, Dreyer BE, Stemerman MB, Pitlick FA. Tissue-factor coagulant activity of cultured human endothelial and smooth muscle cells and fibroblasts. Blood. 1977;50:387-96.

30. Bach R, Rifkin DB. Expression of tissue factor procoagulant activity: regulation by cytosolic calcium. Proc Natl Acad Sci U S A. 1990;87:6995-9.

31. Drake TA, Ruf W, Morrissey JH, Edgington TS. Functional tissue factor is entirely cell surface expressed on lipopolysaccharide-stimulated human blood monocytes and a constitutively tissue factor-producing neoplastic cell line. $J$ Cell Biol. 1989; 109:389-95.

32. Bevers EM, Comfurius $P$, Dekkers DW, Harmsma $M$, Zwaal RF. Transmembrane phospholipid distribution in blood cells: contral mechanisms and pathophysiological significance. Biol Chem. 1998;379:973-86.

33. Sevinsky JR, Rao LV, Ruf $W$. Ligand-induced protease receptor translocation into caveolae: a mechanism for regulating cell surface proteolysis of the tissue factor-dependent coagulation pathway. J Cell Biol. 1996;133:293-304.

34. Mulder AB, Smit JW, Bom VJ, Blom NR, Ruiters MH, Halie MR, wan der Meer J. Association of smooth muscle cell tissue factor with caveolae. Blood. 1996;88:1306-13.

35. Bach RR, Moldow CF. Mechanism of tissue factor activation on HL-60 cells. Blood. 1997;89:3270-6.

36. McEver RP. Adhesive interactions of leukocytes, platelets, and the vessel wall during hemostasis and inflammation. Thromb Haemost. 2001;86:746-56.

37. Kirchhofer D, Sakariassen KS, Clozel M, Tschopp TB, Hadvary P, Nemerson $Y$, Baumgartner HR. Relationship between tissue factor expression and deposition of fibrin, platelets, and leukocytes on cultured endothelial cells under venous blood flow conditions. Blood. 1993;81:2050-8. 
38. Palabrica $T$, Lobb R, Furie BC, Aronovitz $M$, Benjamin C, Hsu YM, Sajer SA, Furie $B$. Leukocyte accumulation promoting fibrin deposition is mediated in vivo by P-selectin on adherent platelets. Nature. 1992,359:848-51.

39. Goel MS, Diamond SL. Neutrophil enhancement of fibrin deposition under flow through platelet-dependent and -independent mechanisms. Arterioscler Thromb Vasc Biol. 2001;21:2093-8.

40. Rentrop KP. Thrombi in acute coronary syndromes: revisited and revised. Circulation. 2000;101:1619-26.

41. Topol EJ. Toward a new frontier in myocardial reperfusion therapy: emerging platelet preeminence. Circulation. 1998;97:211-8. 

Chest pain is a common presentation complaint in the emergency department and the task of evaluating and diagnosing chest pain is a major challenge in health care. Acute coronary syndromes (ACS) refer to any constellation of clinical symptoms that are compatible with acute myocardial ischemia. ACS therefore encompasses acute myocardial infarction (AMI), unstable angina pectoris (UAP) and sudden cardiac death. More rapid triaging of patients admitted to the hospital with chest pain suggestive of AMl is needed (i) to facilitate early intervention with thrombolytic therapy or angioplasty in patients with AMI, (ii) to determine which patients require admission to the intensive care unit, and (iii) to exclude low-risk patients who can be safely sent home and followed as outpatients (cost reduction).

Commonly, about half of all patients presenting with chest pain is rapidiy identified as low-risk and sent home. Of the other patients with chest pain, in about $40 \%$ of cases diagnosis of AMl is readily made on the basis of clinical history and ECG changes; in the remaining 60\%, however, AMI diagnosis and its discrimination from UAP is not easy while the prevalence of AMI is low (about $10 \%$ ). AMI diagnosis in this subgroup of patients is usually made with plasma (or serum) markers of myocardial necrosis, but these markers show poor performance in the early hours after AMI. Since intra-coronary blood clot formation precedes coronary occlusion and muscle necrosis, detection of activated coagulation potentially allows early detection of AMI.

Intra-coronary thrombosis plays a key role in the pathogenesis of ACS, and it has been shown that the prothrombotic activity of human atherosclerotic lesions is associated with the presence of tissue factor (TF), a cellular transmembrane protein which, after its exposure to blood, initiates blood coagulation. As a result, for many years, the prevailing view on acute intracoronary thrombosis has been that it is caused by exposure to plasma of TF in endothelial lesions, for instance due to plaque rupture. More recently, however, a novel hypothesis has been put forward in which TF present in the circulating blood may participate in hemostasis and thrombosis. In this view, microparticle-associated TF that circulates in plasma plays a significant role in hemostasis by enabling the generation of fibrin at the site of the growing thrombus.

A number of studies have reported increased plasma TF antigen levels in the acute phase in patients with UAP and AMI, but the interpretation of these data is complicated by the fact that it is not clear whether plasma TF is in a functional or in a non-functional form. Since a small amount of active TF in plasma would cause acute thrombosis, it is clear that in situ functionality must be limited, but the protein could circulate in an 'encrypted' or a potentially active form. Such encryption could be undone by various (patho-) 
physiological triggers, such as by the exposure of procoagulant cellular phospholipids. Alternatively, plasma TF antigen could partially consist of irreversibly damaged molecules, still retaining their antigenic epitopes, for instance due to proteolytic activity in plasma as has been described for several other proteins. Also, a less active form of plasma TF, alternativelyspliced human TF (ashTF), has recently been described. Unfortunately, due to the limited availability of assays that are capable of measuring plasma TF activity, the role of plasma TF remains poorly understood.

Therefore, the principal aims of the studies described in this thesis were to develop sensitive assays for the measurement of TF antigen and of TF activity in plasma, and to evaluate the use of plasma TF antigen and TF activity, in combination with other markers of activated blood coagulation and with fatty acid-binding protein (FABP, an early marker of myocardial necrosis) in the diagnosis of patients presenting at the emergency department with chest pain suggestive of ACS.

In Chapter 1 a brief introduction into the diagnosis of ACS is provided. It is explained that markers of myocardial necrosis are important in a number of cases, but that they are not detectable until a few hours after the acute event. In contrast, markers of coagulation activation are rapidly cleared from the circulation, and thus become less useful with longer periods after the acute event. Therefore, in order to establish an accurate diagnosis that is independent on the delay of the patient to the hospital, it could be useful to combine plasma markers of coagulation activation and plasma markers of myocardial necrosis.

A survey of important studies that have evaluated plasma levels of coagulation markers in the early hours after onset of ACS is presented in Chapter 2. Only studies were discussed in which blood sampling in ACS patients had been performed on admission to the hospital, before antithrombotic or thrombolytic medication had been administered or revascularization procedures were initiated, and in which markers in these patients were compared with at least one control group. It was evident from these studies that, although there is compelling evidence for a major role of arterial thrombosis in the development of ACS, only a few studies have reported on the sensitivity and specificity of hemostatic markers and their combination with markers of myocardial necrosis to detect ACS in a clinical setting. The results from these studies were non-conclusive and were difficult to compare because they differed in: i) inclusion/exclusion criteria; ii) definitions of AMI and UAP; iii) reference groups; iv) assays and v) cut-off values that were used.

In Chapter 3 the development of a new enzyme-linked immunosorbent assay (ELISA) for measurement of plasma TF antigen is described, using high- 
affinity monoclonal antibodies that were raised against recombinant soluble TF. In healthy donors normal ranges for plasma TF antigen were $2.5(1.0-9.3)$ $\mathrm{pM}, 3.4(2.2-17.6) \mathrm{pM}, 3.4(2.4-19.2) \mathrm{pM}$ and $2.8(1.3-9.8) \mathrm{pM}$ for citrated, EDTA, heparinized plasma and serum, respectively. Furthermore, in plasma samples from type 2 diabetic patients intra-individual TF antigen variation for this new assay (14\%) was lower than for the Imubind TF ELISA (49\%), a commercial ELISA that is often used to study plasma TF antigen levels. The difference is explained by the fact that the new ELISA has a detection limit of $40 \mathrm{fM}$, which is about 6 times lower than that for existing assays. Apparently, much of the earlier reported large intra-individual variation was caused by assay imprecision. Plasma TF antigen levels in type 2 diabetic patients were $3.0(0.9-24.3) \mathrm{pM}$, and were not significantly different from those in healthy donors (2.5 (1.0-9.3) pM).

A capture assay for measurement of plasma TF activity is described in Chapter 4. This assay uses one of the high-affinity anti-TF antibodies that were also used in the new ELISA, bound to Affigel. After capture from plasma, the TF was eluted from the gel and reconstituted into phospholipid-glucoside micelles, avoiding time-consuming dialysis. Full-length recombinant human TF is used as activity calibrator which, by determination of its $k_{\text {cat }}\left(1.9 \pm 0.2 \mathrm{~s}^{-1}\right)$, allows expression of activities in pM of active protein. The detection limit for this assay is $80 \mathrm{fM}$. All plasma TF was found to be exposed for capture, and in healthy donors normal ranges for plasma TF activity were $2.0(1.3-4.2) \mathrm{pM}$ and $2.3(1.3-5.3) \mathrm{pM}$ for citrated and EDTA plasma, respectively. No plasma TF activity was found in heparinized plasma and serum, which may be explained by inhibition of TF by its natural inhibitor: tissue factor pathway inhibitor (TFPI). No TF activity was found for plasma TF in its in vivo proteo-lipid matrix, and it was concluded that TF activity in systemic plasma is 'encrypted', possibly due to the absence of procoagulant phospholipids. However, the majority of TF antigen in plasma is 'potentially active', i.e., can be reactivated after incorporating TF into a procoagulant phospholipid matrix.

The characteristics of FABP, considered to be the earliest marker of myocardial necrosis, are reviewed in Chapter 5 . For patients not treated with thrombolytics, elevated plasma FABP levels are detectable as soon as 1.3 hours after onset of AMI, whereas peak values are reached 6-8 hours after onset of AMI. Plasma FABP levels return to their reference value within 24-36 hours after the onset of chest pain, indicating the usefulness of this marker particularly for the assessment of recurrent infarction. Several clinical studies with patients suspected of having AMI reveal a superior performance of FABP over myoglobin (often used as early necrosis marker) for the early detection of AMI. This finding is likely due to marked differences in tissue contents of FABP and myoglobin in cardiac and skeletal muscles that result in a relatively low upper reference concentration in plasma for FABP $(6 \mu \mathrm{g} / \mathrm{L})$ compared with 
that for myoglobin $(60 \mu \mathrm{g} / \mathrm{L})$. The differences in tissue contents are also reflected in the plasma concentrations of these proteins after either cardiac or skeletal muscle injury, in such a manner that the ratio of the plasma concentrations of myoglobin and FABP can be applied to discriminate myocardial from skeletal muscle injury.

In Chapter 6, the new TF assays were used to study plasma TF antigen and TF activity levels in ACS patients. The median value (with range) of 2.2 (1.19.8) PM for TF antigen found in non-cardiac chest pain patients confirmed the values that were found in healthy controls $(2.5(1.0-9.3) \mathrm{pM})$. Most TF antigen circulated in a potentially active form, the remaining $20-30 \%$ of TF antigen could consist of a recently detected alternatively-spliced variant. When left in its in vivo state, TF captured from plasma was totally inactive, possibly due to the absence of a procoagulant matrix. Compared to the TF activity of controls with non-cardiac chest pain $(1.7(0.3-31.8) \mathrm{pM})$, TF activity in ACS patients was unchanged $(2.0(0.4-24.2) \mathrm{pM})$ and TF antigen was about $25 \%$ elevated in ACS patients $(2.7(1.3-14.8) \mathrm{pM})$. In a diagnostic panel with prothrombin fragment $1+2(F 1+2)$ and $F A B P$, TF antigen elevations did not significantly improve the early diagnosis of ACS.

Finally, in Chapter 7, the main findings of this thesis are summarized and their contributions to the thoughts on the current role of plasma TF in hemostasis and thrombosis are discussed. 
Pijn op de borst is een klacht die vaak wordt gehoord op de spoedeisende hulp. Bij een dergelijke klacht is het in een aantal gevallen nog moeilijk om snel een juiste diagnose te stellen. Acute coronaire syndromen (ACS) worden gekenmerkt door klinische symptomen die duiden op de aanwezigheid van cardiale ischemie - zuurstofgebrek in het hart. ACS zijn het acute hartinfarct (AMl, acute myocardial infarction), instabiele angina pectoris (UAP, unstable angina pectoris) en plotselinge hartdood. Een snelle diagnose bij patiënten die zich presenteren met pijn op de borst is nodig om: (i) bij AMl-patiënten een vroege interventie met trombolytische therapie of revascularisatie-procedures mogelijk te maken, (ii) te bepalen welke patiënten moeten worden opgenomen op de intensive care-afdeling, (iii) patiënten met weinig risico op complicaties snel en veilig naar huis te sturen (kostenbesparing).

Van ongeveer de helft van alle patiënten die zich presenteren met pijn op de borst wordt vastgesteld dat ze weinig risico lopen op complicaties: ze kunnen veilig naar huis worden gestuurd. Van de overige patiënten met pijn op de borst wordt in ongeveer $40 \%$, op basis van hun klinische voorgeschiedenis en veranderingen die op het electrocardiogram (ECG) zichtbaar zijn, de diagnose AMI gesteld. In de resterende $60 \%$ is de diagnose AMI en het onderscheid met UAP niet gemakkelijk te maken, terwijl AMI in deze groep uiteindelijk maar weinig voorkomt $(-10 \%)$. De diagnose AMI wordt in deze groep gesteld na het meten van de concentraties en/of activiteiten van markers van hartspierweefselschade in (bloed-)plasma of serum. Markers van hartspierweefselschade zijn echter niet bruikbaar in de eerste uren na AMI. Aangezien AMI meestal het gevolg is van een bloedstolsel, dat zich vormt op een geruptureerde atherosclerotische plaque en vervolgens een kransslagader geheel afsluit, maakt het meten van markers van geactiveerde bloedstolling in plasma wellicht een vroege detectie van AMI mogelijk.

$\mathrm{Er}$ is aangetoond dat de mate van stolselvorming op gescheurde atherosclerotische plaques sterk samenhangt met de aanwezigheid van tissue factor (TF) daarin. TF, dat zich in de vaatwand bevindt, is een transmembraan-eiwit dat de bloedstollingscascade start als het in contact. komt met de stollingsfactoren in het bloed. Het endotheel aan de binnenkant van de vaatwand vormt een barrière tussen het vaatwand-TF en deze stollingsfactoren. Jarenlang werd gedacht dat hemostase (of trombose) werd veroorzaakt doordat vaatwand-TF na beschadiging van het endotheel (of geruptureerde atherosclerotische plaques) werd blootgesteld aan het bloed. Recentelijk is echter aangetoond dat TF onder fysiologische omstandigheden niet alleen in de vaatwand zit, maar ook in het bloed! Sindsdien zijn wetenschappers geïnteresseerd in de rol van dit zogenoemde "blood-borne TF" in hemostase en trombose. Op basis van de huidige kennis veronderstelt men 
dat TF, dat gebonden aan micropartikels in plasma circuleert, mogelijk belangrijk is voor de vorming van fibrine op het oppervlak van het groeiende stolsel.

Een aantal publicaties laten verhoogde waarden van TF-antigeen (TFconcentraties) in plasma zien in de eerste uren van UAP en AMI. Omdat onduidelijk is of het plasma-TF in een functionele vorm circuleert, is het moeilijk om te zeggen wat dit betekent. Aangezien al een klein beetje actieve TF in plasma onmiddellijk trombose veroorzaakt, ligt het voor de hand te veronderstellen dat de TF-activiteit in plasma in vivo laag zal zijn. Het is echter onduidelijk in welke vorm plasma-TF circuleert. TF zou in een 'encrypted'-vorm kunnen circuleren, d.w.z., TF is inactief, maar kan actief worden gemaakt door verschillende (patho-)fysiologische 'triggers', bijv. door het in contact te brengen met procoagulante cellulaire fosfolipiden. Ook zou TF in plasma irreversibel beschadigd (maar nog wel antigeen) kunnen zijn, bijv. door proteolytische activiteit in plasma, zoals ook voor andere eiwitten is beschreven. Een minder functionele vorm van TF in plasma is beschreven 'alternatively-spliced human TF' (ashTF). Doordat een geschikte methode voor het meten van TF-activiteit in plasma ontbreekt, is de rol van het plasma-TF in hemostase en trombose nog niet opgehelderd.

De belangrijkste doelstellingen van het in dit proefschrift beschreven onderzoek waren: i) het ontwikkelen van gevoelige methoden om TF-antigeen en TF-activiteit in plasma te kunnen meten, ii) het evalueren van het meten van TF-antigeen en TF-activiteit in combinatie met enkele andere bloedstollingsmarkers en met fatty acid-binding protein (FABP, een vroege marker van hartspierweefselschade) in de diagnose van patiënten die zich in het ziekenhuis presenteren met pijn op de borst.

In Hoofdstuk 1 wordt uitgelegd wat acute coronaire syndromen zijn, en hoe de diagnose AMI wordt gesteld. In een aantal situaties zijn hartspierweefselmarkers hierbij onmisbaar, maar deze kunnen pas enkele uren na het begin van een AMI in het bloed worden gemeten. Markers van stollingsactivatie zijn vaak verhoogd na AMI, maar worden ook weer snel uit het bloed geklaard. Naarmate het langer geleden is dat de pijn op de borst voor het eerst werd gevoeld, worden deze stollingsmarkers dus minder bruikbaar. Om onafhankelijk van de vertraging van de patiënt tot het ziekenhuis snel een juiste diagnose te kunnen stellen, lijkt het zinvol markers van bloedstollingsactivatie en hartspierweefselschade te combineren.

In Hoofdstuk 2 wordt een overzicht gegeven van belangrijke studies die stollingsactivatie in de eerste uren na het begin van ACS hebben bestudeerd. Alleen studies worden besproken waarbij bloed werd afgenomen voór antitrombotische of trombolytische medicatie werd toegediend, en/of revascularisatieprocedures werden gestart. Ook moesten de stollingsmarkers 
in de ACS-groepen zijn vergeleken met minimaal én controlegroep. Hoewel er overtuigend bewijs is voor een belangrijke rol van arteriële trombose in de pathogenese van ACS, blijkt uit dit overzicht dat er maar enkele studies zijn die de sensitiviteit en specificiteit van stollingsmarkers in een klinische studie hebben bepaald. Uit het overzicht zijn geen eenduidige conclusies te trekken: de studies zijn moeilijk te vergelijken ondat ze verschillen in: i) inclusie-en exclusiecriteria; ii) gehanteerde definities van AMI en UAP; iii) gebruikte referentiegroepen; iv) gebruikte assays (meetmethoden) en v) gekozen grenswaarden (cut-off waarden).

De ontwikkeling van een nieuw immunoassay (ELISA, enzyme-linked immunosorbent assay) voor het meten van TF-antigeen in plasma wordt beschreven in Hoofdstuk 3. In dit assay worden monoclonale antistoffen gebruikt met een hoge affiniteit voor TF die zijn opgewekt tegen 'recombinant soluble TF'. Het referentie-interval voor TF-antigeen is bepaald in plasma van gezonde donoren, en was $2.5(1.0-9.3) \mathrm{pM}, 3.4(2.2-17.6) \mathrm{pM}, 3.4(2.4-19.2)$ pM en 2.8 (1.3-9.8) pM TF-antigeen voor citraat-, EDTA-, heparineplasma en serum, respectievelijk. In plasma van patiënten met type 2 diabetes werd aangetoond dat de intra-individuele variatie voor dit nieuwe assay (14\%) lager is dan voor de Imubind TF ELISA (49\%), een commerciële ELISA die in de literatuur vaak is beschreven. Het verschil wordt verklaard doordat de nieuwe ELISA een detectielimiet heeft van $40 \mathrm{fM}$. Dat is zo'n 6 keer lager dan die van de meeste andere TF-assays. De intra-individuele variatie van het nieuwe TFassay wordt grotendeels veroorzaakt door de inter-assayvariatie. Bij patiënten met type 2 diabetes $(3.0(0.9-24.3) \mathrm{pM})$ werd geen verschil in TF-antigeen gemeten ten opzichte van gezonde donoren (2.5 (1.0-9.3) pM).

Een nieuw assay voor het meten van TF-activiteit in plasma wordt beschreven in Hoofdstuk 4. Een van de TF-antistoffen die worden gebruikt in de ELISA, wordt in dit assay gekoppel.d aan agarose-gel. Hiermee wordt het TF uit plasma gevangen. Na het wegwassen van de niet-gebonden bestanddelen van plasma, wordt het TF losgemaakt van de gel en opgenomen in fosfolipiden-glucoside micellen. Een tijdrovende dialyseprocedure wäs niet nodig om de TF-activiteit van het gereconstitueerde TF te kunnen bepalen. Als calibrator wordt 'full-length recombinant human TF' gebruikt. Door de katalytische constante $\left(k_{\text {cat }}\right)$ van de calibrator $\left(1.9 \pm 0.2 \mathrm{~s}^{-1}\right)$ te bepalen, kon de TF-activiteit in plasma worden uitgedrukt in $\mathrm{pmol} / \mathrm{L}$ actief eiwit. De detectielimiet van het assay is $80 \mathrm{fM}$.

Alle TF kon uit het plasma worden gebonden, dus TF in plasma is volledig geëxposeerd. Het referentie-interval voor TF-activiteit werd bepaald in plasma van gezonde donoren en was $2.0(1.3-4.2) \mathrm{pM}$ en $2.3(1.3-5.3) \mathrm{pM}$ voor citraat- en EDTA-plasma, respectievelijk. In heparineplasma en serum werd geen TF-activiteit gevonden. Dit wordt mogelijk veroorzaakt doordat de natuurlijke remmer van TF-activiteit in plasma (tissue factor pathway 
inhibitor (TFPI) in heparineplasma en serum actief is. Er werd ook geen TFactiviteit gevonden voor TF in zijn in vivo matrix. Daarom werd geconcludeerd dat TF-activiteit in plasma 'encrypted' (afgeschermd) is, mogelijk door de afwezigheid van procoagulante fosfolipiden. Toch is de meerderheid van het TF in plasma "potentieel actief": het meeste TF in plasma kon actief worden gemaakt door het op te nemen in een procoagulante fosfolipidenmatrix.

De eigenschappen van $F A B P$, dat wordt beschouwd als de vroegste marker van hartspierweefselschade, worden besproken in Hoofdstuk 5. Bij patiënten die niet met trombolytica zijn behandeld, kunnen 1-3 uur na het begin van AMI verhoogde FABP-concentraties in plasma worden gemeten. De hoogst gemeten waarde (peak value) van FABP wordt 6-8 uur na het begin van AMI gemeten. De FABP-waarden in plasma zijn 24-36 uur na het begin van pijn op de borst weer normaal, zodat deze marker ook uitermate geschikt is om een nieuw infarct te detecteren. Uit klinische studies blijkt dat FABP een betere marker voor de vroege detectie van AMl is dan myoglobine (dat nu nog vaak wordt gebruikt als vroegste hartspierweefselmarker). Waarschijnlijk komt dit door het verschil in weefselgehalte van FABP en myoglobine in hart- en skeletspierweefsel. FABP heeft een relatief lagere bovenste referentiewaarde in plasma $(6 \mu \mathrm{g} / \mathrm{L})$ dan myoglobine $(60 \mu \mathrm{g} / \mathrm{L})$. Dit verschil komt ook tot uitdrukking in de plasmaconcentraties van deze eiwitten na hart- of skeletspierschade. Zo kan de verhouding in plasmaconcentratie van myoglobine en FABP worden gebruikt om onderscheid te maken tussen harten skeletspierschade.

In Hoofdstuk 6 worden de nieuwe assays gebruikt om TF-antigeen en TFactiviteit in plasma van ACS-patiënten te bepalen. De mediaan (met bereik) van $2.2(1.1-9.8) \mathrm{pM}$ voor TF-antigeen die werd gemeten in de NCCPcontrolegroep (non-cardiac chest pain) bevestigt de waarden die eerder werden gemeten in het plasma van gezonde donoren $(2.5(1.0-9.3) \mathrm{pM})$. Het meeste TF-antigeen circuleert in een potentieel actieve vorm. De resterende 20-30\% bestaat mogelijk uit 'alternatively-spliced human TF'. Vergeleken met de TF-activiteit van de NCCP-groep $(1.7(0.3-31.8) \mathrm{pM})$, was de TF-activiteit in ACS patiënten niet verhoogd $(2.0(0.4-24.2) \mathrm{pM})$. TF-antigeen was ongeveer $25 \%$ verhoogd in ACS patiënten (2.7(1.3-14.8) $\mathrm{pM})$, maar in een panel met protrombine fragment $1+2$ en FABP, had TF-antigeen geen toegevoegde waarde bij de diagnose van ACS.

Tenslotte worden in Hoofdstuk 7 de belangrijkste bevindingen van dit proefschrift nog eens samengevat en wordt de bijdrage hiervan aan de ideeën over de mogelijke rol van plasma-TF in hemostase and trombose besproken. 
Aan het eind van zo'n bloedstollend onderzoek is er dan ook nog zoiets als een dankwoord. JEEZ, wat lastig! Bang om iemand te vergeten. Maar goed, daar gaan we dan...

Beste Wim, eigenlijk weet ik niet waar ik moet beginnen. Dus noem ik maar gewoon wat me als eerste te binnen schiet: dit proefschrift was er nooit gekomen zonder jouw inzet. De deur stond altijd open om de laatste resultaten te bespreken. En hoe uitzichtloos de situatie soms ook leek: met jouw kritische blik, ervaring en deskundigheid wist je altijd weer de juiste draai aan het onderzoek te geven. Het enthousiasme dat je uitstraalde en het vertrouwen dat je gaf, hield me op de been wanneer ik het even niet zag zitten. En toen ik naar Rotterdam vertrok om mij volledig in de wereld van het nieuws te storten, nam jij in Maastricht gewoon het werk over dat ik achterliet! Wie zou zoiets nog meer doen? Dat heb ik me geregeld afgevraagd. Enorm bedankt!

Beste Jan, hoewel jij van huis uit geen "stoller" bent, is ook jouw bijdrage aan dit proefschrift groot. Met jouw energie en je bijna grenzeloze optimisme wist je mij ervan te overtuigen dat ik de eindstreep kon halen. De memo die je schreef toen de Nederlandse Hartstichting besloot ons projekt niet meer te steunen, is daar een goed voorbeeld van: Beste Roy, met Wim heb ik al gebrainstormd over ons antwoord. Hopelijk redden we ans er wel uit. Het devies is: optimistisch blijven en blijven lachen - Jan. Je had gelijk! Jouw kennis van immunoassays en ervaring met klinische onderzoeken was onontbeerlijk.

Van jullie allebei heb ik ontzettend veel geleerd. Bedankt voor alles!

Pap en mam, dit proefschrift draag ik op aan jullie. Bedankt dat jullie me de kans hebben gegeven om te studeren en mezelf te ontwikkelen. Mijn promotie hebben jullie vanaf de zijlijn meegemaakt. En misschien was dat nog wel heftiger dan hoe ik het heb beleefd. Voetballers die op de bank zitten, zeggen het kijken naar een wedstrijd ook spannender te vinden dan wanneer ze zelf op het veld staan. Ondanks dat jullie mijn keuzes niet altijd begrijpen, steunen jullie me elke keer weer. Is dat niet wat ze onvoorwaardelijke liefde noemen? Hoe kan ik jullie ooit bedanken?

Lieve Natasja, ook bij jou sta ik in het krijt. Bedankt dat je mij hebt binnengelaten in de wereld van NDRF: Natasja-Derived Relaxing Factor. Wat hebben wij veel tijd samen doorgebracht! 'Bij jou? Bij mij? Of in de stad?' Even een kopje koffie - later Senseo - en bijkletsen. Lief en leed hebben wij gedeeld; oké, jij was daar wat beter in dan ik. Ons uitstapje naar Toscane en Umbrië zal ik in ieder geval nooit vergeten. Heel veel succes met het afronden 
van jouw promotieonderzoek. Jouw boekje wordt er een om trots op te zijn. Je bent een fantastische AlO-pener!

Beste Thamar (Tee), globetrotter. Dude, you're a true friend. Thanks 4 being U!

Lieve Petra, wat geweldig zoals $\mathrm{jij}$ in het leven staat! Jij hebt levensvreugde voor, voor, voor... een heel elftal. Bedankt dat ik geregeld een van die elf mag zijn. Carpe diem!

Lieve Debby (dee-pee-ei), wat jammer dat jij er vandaag niet bij bent! Zowet bij Fysiologie als bij Moleculaire Genetica was je immers mijn beste maatje. En nu zit je daar in Edmonton of all places! Wanneer kom je weer eens langs? Kopje cappuccino op het Vrijthof? Heel veel succes met je onderzoek in Canada!

Beste Daniëlle en Maurice, lotgenoten, biopartners. We hebben een paar jaar een kamer gedeeld. Het was fijn om zo'n vraagbaak als jou naast me te hebben, Maurice! Ik bewaar het FABP (First Address for Boogsport Promotions, of zoeee) in mijn knip. Daan, hoe haal je het in je hoofd om stollingsonderzoek te gaan doen? Heb je de afgelopen jaren dan niet opgelet tijdens onze werkbesprekingen?! Maar als ik je ergens mee kan helpen? 0624088032. Ik herhaal: 06-24088032. Heel veel succes - en geluk - samen!

De rest van Jans groep: Jodil (this is between you, me...), Joep, Joost, Susan en Will (waar een Will is...). Andries (als sofa's konden praten...). Danny (Ro-town is zo gek nog niet!).

Van Sanquin, Amsterdam: Henk, Hanny en Lucien: bedankt voor de liters (slik!) antistoffen. Van Biochemie, Maastricht: Theo, Peter en René, ontzettend bedankt voor alle hulp en suggesties. Dear Prof. Morrissey: none of the work in this thesis would have been possible without your help. Thank you so much for providing TF and for valuable discussions!

Dan mijn paranimfen.

Beste Harald, ongeveer dertien jaar geleden namen we samen de trein van Weert naar Eindhoven om daar Scheikundige Technologie te gaan studeren. We hadden er toen al zes jaar Wwo in Weert opzitten. Daarna pakten we de trein in de tegenovergestelde richting. Naar Maastricht, waar we allebei AlO werden. I $k$ had het voorrecht een van jouw paranimfen te mogen zijn. En nu ben jij mijn paranimf. Jarenlang zaten we op hetzelfde spoor. Maar morgen spring ik in een andere trein... Lieve Babette, ook wij kennen elkaar al lang. Ik denk vaak dat wij als twee druppels water zijn, want wat voelen wij elkaar goed aan! Het is fantastisch om een soulmate als jou te hebben!

Jullie bezitten een speciaal plekje in mijn hart. Wat geweldig dat jullie vandaag mijn paranimfen zijn!

Overige vrienden en collega's... Bas, Carla, Chantal, Femke, Harm, Isabel, Ischa, Janine, Karin, Kim, Marjan, Monique, René, Richard, Rob, Roy, Ruud, 
Sandra, Suzanne, Yvonne. Anita, Appie, Arjen, Ben, Bianca, Céline, Claire, Claudia, Daniëlle, Daphna, Dick, Didier, Elisabetta, Elke, Ferdi, Frank, Frans, Geertje, Gerry, Guillaume, Han, Hanneke, Hans, Henri, Hugo, Inge, Iris, Jart, Jean, Jolanda, Jos, Joyce, Karin, Kristel, Kristiaan, Le, Luc, Marc, Marcel, Marie-Louise, Marion, Marten, Martin, Mathys, Menno, Miriam, Mirjam, Monique, Monique, Nard, Pascal, Patrick, Peter, Petra, Richard, Ronit, Rory, Sander, Stella, Steven, Stijn, Theo, Veerle, Vivian, Viviane, Willem, Wilma...

... en iedereen van Fysiologie, Moleculaire Genetica, Biochemie, Klinische Chemie en Cardiologie die ik vergeten ben maar ook recht heeft op een plekje in dit dankwoord. Sorry!

Thanks y'all!

\section{DID IT MY WAY.}

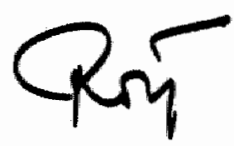

Maastricht,

2 november 2005

"She buzzed the tape forward to Steve Earle's "Fearless Heart', with its intricate swagger. No one but Steve Earle for her in the worst of times. There was a thump in her blood, a sexual hip in her movement, when she heard any of his songs of furious loss." 



\section{CURRICULUM VITAE}

Roy FM van der Putten

Born on August 15, 1974 in Nijmegen

Education

1986-1992 Atheneum, Philips van Horne comprehensive school, Weert

1992-1998 Chemical Engineering, Eindhoven University of Technology, Eindhoven

1999-2005 PhD-course programme of the Cardiovascular Research Institute Maastricht (CARIM)

2003

Course on working with radiation level $5 \mathrm{~B}$

Research

1997

Student-researcher under supervision of Dr. PTJ Spierings, Spierings Orthopaedics, Nijmegen

1998

Student-researcher under supervision of Prof. dr. HL Vader, Maxima Medical Center, Velthoven

1999-2005 PhD-student under supervision of Prof. dr. WT Hermens and Prof. dr. JFC Glatz at the departments of Genetics \& Cell Biology and Physiology, Cardiovascular Research Institute Maastricht (CARIM), Maastricht University, Maastricht 